\title{
Memory before Modernity
}




\title{
Studies in Medieval and Reformation Traditions
}

\author{
Edited by \\ Andrew Colin Gow, Edmonton, Alberta \\ In cooperation with \\ Sylvia Brown, Edmonton, Alberta \\ Falk Eisermann, Berlin \\ Berndt Hamm, Erlangen \\ Johannes Heil, Heidelberg \\ Susan C. Karant-Nunn, Tucson, Arizona \\ Martin Kaufhold, Augsburg \\ Erik Kwakkel, Leiden \\ Jürgen Miethke, Heidelberg \\ Christopher Ocker, San Anselmo and Berkeley, California
}

Founding Editor

Heiko A. Oberman $\dagger$

VOLUME 176

The titles published in this series are listed at brill.com/smrt 


\title{
Memory before Modernity
}

Practices of Memory in Early Modern Europe

\author{
Edited by \\ Erika Kuijpers \\ Judith Pollmann \\ Johannes Müller \\ Jasper van der Steen
}

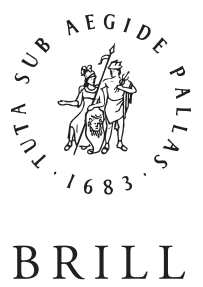

LEIDEN • BOSTON

2013 
The digital edition of this title is published in Open Access.

Cover illustration: Memorial tablet in the façade of the so-called 'Spanish House' in the Holland town of Naarden, located on the spot of the former town hall. In 1572 during the Dutch Revolt, 700 men from Naarden were gathered here and killed by Habsburg troops. The town hall was burnt down and rebuilt in 1615. (Photo Ralf Akemann).

Library of Congress Cataloging-in-Publication Data

Memory before modernity : practices of memory in early modern Europe / edited by Erika Kuijpers, Judith Pollmann, Johannes Müller, Jasper van der Steen.

pages cm. - (Studies in medieval and Reformation traditions, ISSN 1573-4188; volume 176)

Includes bibliographical references and index.

ISBN 978-90-04-26124-2 (hardback : acid-free paper) — ISBN 978-90-04-26125-9 (e-book)

1. Memory-Social aspects—Europe-History—16th century. 2. Memory-Social aspects-

Europe-History - 17th century. 3. Loss (Psychology) - Social aspects-Europe-History.

4. Social conflict-Europe-History. 5. Politics and culture-Europe-History. 6. EuropeHistory-1492-1648. 7. Europe-History, Military-1492-1648. 8. Europe-Social conditions. 9. Europe-Civilization. I. Kuijpers, Erika, 1967- II. Pollmann, Judith. III. Müller, Johannes (Johannes M.), 1980- IV. Steen, Jasper van der.

D210.M385 2013

$940.2-\mathrm{dc} 23$

2013034216

This publication has been typeset in the multilingual "Brill" typeface. With over 5,100 characters covering Latin, IPA, Greek, and Cyrillic, this typeface is especially suitable for use in the humanities. For more information, please see www.brill.com/brill-typeface.

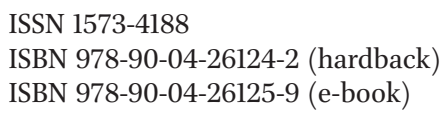

ISSN $1573-4188$

ISBN 978-90-04-26124-2 (hardback)

ISBN 978-90-04-26125-9 (e-book)

Copyright 2013 by Koninklijke Brill NV, Leiden, The Netherlands.

Koninklijke Brill NV incorporates the imprints Brill, Global Oriental, Hotei Publishing, IDC Publishers and Martinus Nijhoff Publishers.

All rights reserved. No part of this publication may be reproduced, translated, stored in a retrieval system, or transmitted in any form or by any means, electronic, mechanical, photocopying, recording or otherwise, without prior written permission from the publisher.

Authorization to photocopy items for internal or personal use is granted by Koninklijke Brill NV provided that the appropriate fees are paid directly to The Copyright Clearance Center, 222 Rosewood Drive, Suite 910, Danvers, MA 01923, USA.

Fees are subject to change.

This book is printed on acid-free paper. 


\section{CONTENTS}

Acknowledgements ................................................................................. ix

List of Contributors ....................................................................................... xi

List of Illustrations

Introduction. On the Early Modernity of Modern Memory ............... 1 Judith Pollmann and Erika Kuijpers

PART I

\section{MEMORY POLITICS AND MEMORY WARS}

1. The Usable Past in the Lemberg Armenian Community's Struggle for Equal Rights, 1578-1654

Alexandr Osipian

2. A Contested Past. Memory Wars during the Twelve Years Truce (1609-21)

Jasper van der Steen

3. 'You Will See Who They Are that Revile, and Lessen Your... Glorious Deliverance'. The 'Memory War' about the 'Glorious Revolution'

Ulrich Niggemann

4. Civic and Confessional Memory in Conflict. Augsburg in the Sixteenth Century

Sean F. Dunwoody

5. Tales of a Peasant Revolt. Taboos and Memories of 1514 in Hungary

Gabriella Erdélyi

6. Shaping the Memory of the French Wars of Religion.

The First Centuries

Philip Benedict 
PART II

MEDIALITY

7. Celebrating a Trojan Horse. Memories of the Dutch Revolt in Breda, 1590-1650

Marianne Eekhout

8. 'The Odious Demon from Across the Sea'. Oliver Cromwell, Memory and the Dislocations of Ireland

Sarah Covington

9. Material Memories of the Guildsmen. Crafting Identities in Early Modern London 165 Jasmine Kilburn-Toppin

10. Between Storytelling and Patriotic Scripture. The Memory Brokers of the Dutch Revolt 183 Erika Kuijpers

11. Lost in Time and Space? Glocal Memoryscapes in the Early Modern World

Dagmar Freist

12. The Spaces of Memory and their Transmediations. On the Lives of Exotic Images and their Material Evocations 223 Benjamin Schmidt

PART III

\section{PERSONAL MEMORY}

13. Disturbing Memories. Narrating Experiences and Emotions of Distressing Events in the French Wars of Religion 253 Susan Broomhall

14. Remembering Fear. The Fear of Violence and the Violence of Fear in Seventeenth-Century War Memories 269 Andreas Bähr 
15. Permeable Memories. Family History and the Diaspora of Southern Netherlandish Exiles in the Seventeenth Century $\quad . . . . . \quad 283$ Johannes Müller

16. Women, Memory and Family History in Seventeenth-Century England

Katharine Hodgkin

17. The Experience of Rupture and the History of Memory

Brecht Deseure and Judith Pollmann

Index 
Erika Kuijpers, Judith Pollmann, Johannes Müller, and Jasper van der Steen - 978-90-04-26125-9 Downloaded from Brill.com04/26/2023 11:57:20AM via free access 


\section{ACKNOWLEDGEMENTS}

The essays in this volume were first conceived as papers for the conference Memory before Modernity. Memory cultures in early modern Europe, that was held in Leiden in June 2012. The conference was organised by the research team Tales of the Revolt. Memory, oblivion and identity in the Low Countries, 1566-1700, which was directed by Judith Pollmann and funded by a VICI grant from the Netherlands Organisation of Scientific research (NWO). The editors would like to thank all who attended the conference for their valuable suggestions and input. We are grateful to the editorial board of the Studies in Medieval and Reformation Traditions, the anonymous peer reviewers, and Arjan van Dijk, Ivo Romein and Thalien Colenbrander at Brill publishers for their enthusiasm and support in seeing this volume through press. Finally, we thank copy editor Kate Delaney and the team's assistant Frank de Hoog, who checked the notes, made the index to this book and offered invaluable assistance throughout the editorial process. 
Erika Kuijpers, Judith Pollmann, Johannes Müller, and Jasper van der Steen - 978-90-04-26125-9 Downloaded from Brill.com04/26/2023 11:57:20AM via free access 


\section{LIST OF CONTRIBUTORS}

Andreas Bähr is a lecturer at the Friedrich-Meinecke-Institut of the Free University of Berlin. In 2013 he published Furcht und Furchtlosigkeit. Göttliche Gewalt und Selbstkonstitution im 17. Jahrhundert (Göttingen 2013). His research interests include early modern violence and disease, the making of the self, the history of religious thought, historical epistemology, and the history of historiography.

Philip Benedict is professor at the Institute of Reformation History of the University of Geneva. His books include Rouen during the Wars of Religion (1981), The faith and fortunes of France's Huguenots 1600-85 (2001), Christ's churches purely Reformed. A social history of Calvinism (2002), Graphic history. The Wars, Massacres and Troubles of Tortorel and Perrissin (2007), and (with Nicolas Fornerod) L'organisation et l'action des Églises réformées de France 1557-1563. Synodes provinciaux et autres documents (2012).

Susan Broomhall is professor of early modern history at The University of Western Australia. She is author of a range of studies on women and gender in early modern Europe, including most recently (with Jennifer Spinks) Early modern women in the Low Countries. Feminising sources and interpretations of the past (Ashgate, 2011). She is currently researching sixteenth- and seventeenth-century French narrators of life accounts who recorded disastrous and violent experiences as part of an Australian Research Council project with Charles Zika and Jennifer Spinks.

Sarah Covington is professor of history at Queens College/The City University of New York, where she specialises in early modern British and Irish history. She is the author of numerous articles as well as two books, The trail of martyrdom. Persecution and resistance in sixteenth century England (Notre Dame University Press, 2003) and Wounds, flesh and metaphor in seventeenth-century England (Palgrave-Macmillan, 2009).

Brecht Deseure defended his $\mathrm{PhD}$ dissertation Een bruikbaar verleden. Geschiedenispolitiek in Belgie tijdens de Franse periode at the University of Antwerp in 2011. Since then he has been teaching at the universities of Antwerp, Leiden and Leuven. He has published on the politics of history 
in revolutionary and Napoleonic France, the experience of crisis in early modern chronicles and constitutional debates in the late 18th century.

Sean Dunwoody is currently a visiting assistant professor of history at Wake Forest University (Winston-Salem, NC, USA). He is working on a book manuscript - a revision of his dissertation defended at the University of Chicago in Summer 2012 - that examines and explains Augsburg's peculiar achievement of maintaining religious peace and an atmosphere of practical toleration in the second half of the sixteenth century, a time at which Europe was consumed by the ravages of religious war.

Marianne Eekhout is a $\mathrm{PhD}$ candidate at Leiden University. Her project is entitled Tangible memories of the Dutch Revolt. Local memory cultures in the Low Countries, 1566-1700. Her research combines the interdisciplinary approaches of memory studies and material culture and provides new insights in the way objects were a part of local memory practices in the Low Countries during and after the Dutch Revolt.

Gabriella Erdélyi is a senior research fellow in the Institute of History, Research Centre for Humanities, Hungarian Academy of Sciences, in Budapest. Her research focuses on the cultural history of late medieval and early modern east central Europe, with particular interest in the social context of religion and the process of Reformation in Hungary, the history of family and marriage as well as of crime, violence and justice. She published two monographs (A convent trial. Religious culture in late medieval Hungary, Budapest, 2005; Violence and youth in late medieval Hungary, Budapest, 2011, both in Hungarian) and two volumes of Latin source editions. Her essays and reviews have appeared in Social History, Journal of Ecclesiastical History, Sixteenth Century Journal and Analecta Augustiniana.

Dagmar Freist is professor of early modern history at Oldenburg University since 2004. She obtained her PhD at Cambridge University and she was a research fellow at the German Historical Institute, London. Her research focuses on political culture and the public sphere in 17th and 18th c. England and Germany, religious diversity in early modern England and Germany, diasporas, and networks, economic and social interaction and cultural transfer in early modern northern Europe. She co-edited a number of books, among them Living with religious diversity in early 
modern Europe, Farnham 2009 and SelbstBildungen. Soziale und kulturelle Praktiken der Subjektivierung, Bielefeld 2013. Her forthcoming books are (ed.) Ein Bild von Mir. Praktiken der Selbstbildung in der Frühen Neuzeit, Bielefeld 2014 and Glaube, Liebe, Zwietracht. Konfessionell gemischte Ehen in Deutschland in der Frühen Neuzeit, München 2014. She is co-speaker of the DFG graduate school Self-Building. Practices of subjectivation in historical and interdisciplinary perspective (http://www.praktiken-dersubjektivierung.de) and member of the Prize Papers Consortium (http:// www.prizepapers.de).

Katharine Hodgkin is a reader in cultural history at the University of East London. She has published articles on many aspects of early modern English culture, including dreams, madness, gender, witchcraft, subjectivity and memory, and is currently running an AHRC-funded network on memory in early modern Britain and how we remember the period today. Her most recent book is an edition of an early seventeenth-century autobiographical account of mental disorder, Women, madness and sin: The autobiographical writings of Dionys Fitzherbert (Ashgate 2010).

Jasmine Kilburn-Toppin has completed her doctoral thesis at the Victoria and Albert Museum / The Royal College of Art this year. Her research explores the spatial, material and social construction of artisanal identities in early modern London.

Erika Kuijpers is a postdoctoral researcher at Leiden University. She is the author of Migrantenstad. Immigratie en sociale verhoudingen in 17e-eeuws Amsterdam (2005). She has published widely on the history of migration, literacy and pre-modern labour markets and, more recently, about the memories of distressing events during the Dutch Revolt. In the context of the VICI research project 'Tales of the revolt: memory, oblivion and iden-

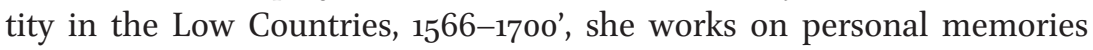
and oral traditions.

Johannes Müller studied Literature and History at the universities of Leiden and Siegen. In 2009 he became a PhD candidate at the Institute for History at Leiden University, where he is currently completing a dissertation on the memory cultures of Dutch exile networks in early modern Europe. He has published on medieval and early modern religious literature as well as on confessional migration after the Reformation. 
Ulrich Niggemann studied History at the universities of Göttingen and Bonn. From 2002 to 2003 he was a research assistant at the acta pacis Westphalicae edition project in Bonn, and from 2003 to 2008 he worked at the University of Marburg. He received a doctorate there in 2007 with a thesis on immigration politics and Huguenot settlement in late seventeenth-century Germany and England. From 2008 to 2011 he participated in a research project on memories of monarchs in early modern Europe. Since 2011 he is Akademischer Rat at the University of Marburg. His current research focuses on the memories of the Glorious Revolution in eighteenth-century Great Britain.

Alexandr Osipian is associate professor of history and cultural anthropology at the Department of History and Cultural Studies at the Kramatorsk Institute of Economics and Humanities, Ukraine. He studies discourses and practices of a usable past construction-history writing, public perceptions of the past, historical imagination, cultural memory-in Eastern Europe in sixteenth-seventeenth century. He conducted research at the Central European University (Hungary), European University Institute (Italy), Warsaw University, Jagiellonian University, Deutsches Historisches Institut Warschau (Poland), University of Leipzig (Germany), and the George Washington University (Washington, DC).

Judith Pollmann is professor of early modern Dutch history at Leiden University in the Netherlands. She has published widely on the Dutch Revolt and the cultural and religious history of the Low Countries. Since 2008 she has been the director of the research project Tales of the Revolt. Memory, oblivion and identity in the Low Countries, 1566-170o, that is funded with a VICI grant from the Netherlands Organisation for Scientific Research. In that context she is currently working on a book provisionally entitled Memory beyond modernity. Europe, 1500-1800.

Benjamin Schmidt is professor of history at the University of Washington, where he specialises in early modern cultural and visual history. His books include the prize-winning Innocence abroad. The Dutch imagination and the New World (2001); Making knowledge in early modern Europe. Practices, objects, and texts (2008; with P. Smith); Going Dutch. The Dutch presence in America, 1609-2009 (2008; with A. Stott); and The discovery of Guiana by Sir Walter Ralegh (2007). His forthcoming Inventing exoticism (2014) explores Europe's engagement with the world circa 1700, paying particular attention to the role of pictures and material arts. 
Jasper van der Steen studied history at the University of Durham. At Leiden University's Institute for History, he is currently finishing his doctoral dissertation on memory politics after the Revolt of the Netherlands: Memory wars in the Low Countries, 1566-1700. His dissertation examines the interplay of public memory, politics and identity in the Dutch Republic and the Habsburg Netherlands. 
Erika Kuijpers, Judith Pollmann, Johannes Müller, and Jasper van der Steen - 978-90-04-26125-9 Downloaded from Brill.com04/26/2023 11:57:20AM via free access 


\title{
LIST OF ILLUSTRATIONS
}

\author{
Jasper van der Steen
}

1a. Image of the Old and New Time, Rijksmuseum

Amsterdam

\section{Gabriella Erdélyi}

2. The execution of Dózsa on the front page of Stephanus Taurinus, Stauromachia (Vindobonae, 1519), with the permission of the National Széchényi Library (Budapest), Régi Nyomtatványok Tára (Collection of Old Prints) 106

3. The execution of Dózsa in Paul Ricaut, Die neu eröffnete Ottomanische Pforte (Augsburg, 1694) vol. 2, p. 106, Library and Information Center of the Hungarian Academy of Sciences, Oriental Collection

\section{Marianne Eekhout}

4a and b. Gerard van Bijlaer, commemorative medal peat barge of Breda, 1590, gold, Noordbrabants Museum 's-Hertogenbosch, front and back

5. Anonymous, portrait of Rochus Rees, 1622, oil on panel, Museum Huis van Gijn, Dordrecht

6. Anonymous, Charles de Heraugières (1556-1601), after 1590, oil on panel, Rijksmuseum Amsterdam

7. Anonymous, Treur-feest der Calvinisten, midtsgaeders de wt-vaert van Breda, 1625, etching, Rijksmuseum Amsterdam

$8 \mathrm{a}$ and $\mathrm{b}$. Johannes Looff, commemorative medal, Breda recaptured by Frederik Hendrik, 1638, silver, Noordbrabantsmuseum 's-Hertogenbosch, front and back 
xviii

9. St George and the Dragon, c. 1528 , polychromed oak, iron, leather and horse hair, Armourérs' Company, London 166

\section{Erika Kuijpers}

10. Lambert Melisz saves his mother from plundering soldiers. Anonymous print 1659-1661, Rijksmuseum Amsterdam 196

\section{Dagmar Freist}

11. St. Elizabeth glass or Hedwigsglas in possession of Martin Luther, 12th century[?] From the art collection of the Veste Coburg, www.kunstsammlungen-coburg.de 220

\section{Benjamin Schmidt}

12. Jacob van Meurs (workshop), frontispiece of Johan Nieuhof, Het gezantschap der Neerlandtsche Ost-Indische Compagnie, aan den grooten Tartarischen Cham, den tegenwoordigen keizer van China (Amsterdam: Jacob van Meurs, 1665), Universiteitsbibliotheek Leiden, Collectie N.H.K. 345 228

13. Johan Nieuhof [?], drawing of a viceroy in 'Journaal van zommige voorvallen, inde voyagie vande E. Heeren Pieter de Goyer en Jacob Keyser, ambassadeurs, aande grootmachtige keizer van Chyna en Tartaryen, inde jaaren 1655, 56 \& 1657' (1659), fol. 23; manuscript in the collection of the Société de Géographie, Bibliothèque Nationale, Paris 230

14. Vase with Cover, ca. $1675 / 80$, Greek A Factory (attrib.), tin-glazed earthenware, $5^{8} \mathrm{~cm}$ (height), The Art Institute Chicago, Anonymous gift in honor of Eloise W. Martin; Eloise W. Martin Fund 232

15a. Hendrik van Soest (attrib.), Cabinet, ca. 1700, oak veneered with walnut, Brazilian rosewood, and padauk, decorated with inlaid pewter, Grassimuseum Für Angewandte Kunst, Leipzig

15b. See fig. 15a. Cabinet, central panel with image of the Chinese emperor, Grassi Museum Für Angewandte Kunst, Leipzig 
16. Johan Nieuhof [?], drawing of ascetics in 'Journaal van zommige voorvallen, inde voyagie vande E. Heeren Pieter de Goyer en Jacob Keyser, ambassadeurs, aande grootmachtige keizer van Chyna en Tartaryen, inde jaaren 1655, 56 \& 1657' (1659), fol. 101; manuscript in the collection of the Sociéte de Géographie, Bibliothèque Nationale, Paris

17. Jacob van Meurs (workshop), 'Mendians', engraved illustration in Johan Nieuhof, Het gezantschap der Neerlandtsche Ost-Indische Compagnie, aan den grooten Tartarischen Cham, den tegenwoordigen keizer van China (Amsterdam: Jacob van Meurs, 1665), vol. 2, p. 35, Universiteitsbibliotheek Leiden, Collectie N.H.K. 345

18. Jacob van Meurs (workshop), 'Mendians', engraved illustration in Johan Nieuhof, Het gezantschap der Neerlandtsche Ost-Indische Compagnie, aan den grooten Tartarischen Cham, den tegenwoordigen keizer van China (Amsterdam: Jacob van Meurs, 1665), vol. 2, p. 36, Universiteitsbibliotheek Leiden, Collectie N.H.K. 345

19. Samuel van Eenhoorn, Greek A Factory, punch bowl, tin-glazed earthenware, (ca. 1680), The Fitzwilliam Museum, Cambridge ...

20. John Stalker and George Parker, 'For Drawers for Cabbinets to be Placed according to your fancy' (plate 18), engraving in Stalker and Parker, A treatise of Japaning and varnishing (Oxford: John Stalker, 1688), Rijksmuseum Amsterdam

21. Jacob van Meurs (workshop), 'Caning', engraved illustration in Olfert Dapper, Gedenckwaerdig bedryf der Nederlansche Oost-Indische Maetschappye, op de kuste en in het keizerrijk van Taising of Sina (Amsterdam: Jacob van Meurs, 1670) p. 478, Universiteitsbibliotheek Leiden

22. Jacob van Meurs (workshop), 'Caning', engraved illustration in Olfert Dapper, Gedenckwaerdig bedryf der Nederlansche Oost-Indische Maetschappye, op de kuste en in het keizerrijk van Taising of Sina (Amsterdam: Jacob van Meurs, 1670) p. 479, Universiteitsbibliotheek Leiden

23. Wall panel, silk with linen, ca. 1700, $328 \mathrm{~cm}$ (height) $\times 96$ (width per panel) Bayerische Verwaltung der staatlichen Schlösser, Gärten und Seen, Residenz München

24. Adriano de las Cortes, 'Relation, with drawings, of his voyage, shipwreck, and captivity at Chanceo in China: 1621-1626', fol. 169 recto, British Library, mss. Sloane 
Erika Kuijpers, Judith Pollmann, Johannes Müller, and Jasper van der Steen - 978-90-04-26125-9 Downloaded from Brill.com04/26/2023 11:57:20AM via free access 


\title{
INTRODUCTION. \\ ON THE EARLY MODERNITY OF MODERN MEMORY*
}

\author{
Judith Pollmann and Erika Kuijpers
}

Most scholars who study memory believe that people in different cultures have different ways of remembering. This assumption implies that it should be possible to write a history of memory. Outlines of such a history can be found in various modern theories of memory, which often contain a macro-historical component. Jacques Le Goff distinguished five phases in the history of memory in the West, in which 'free, creative and vital' memory over time became 'exteriorised'. ${ }^{1}$ Pierre Nora famously argued that 'milieux de mémoire' had given way to lieux de mémoire'.2 Aleida and Jan Assmann have connected media revolutions to the emergence of new forms of cultural memory, while students of nationalism like Benedict Anderson and Eric Hobsbawm saw the combined forces of literacy, political change, mass media, secularization and capitalism as the motor behind the emergence of new approaches to the past. ${ }^{3}$ Increasingly, memory theories also have a 'futurist' component-it is alleged that postmodernity, globalization and/or the information revolution are creating changes that might lead to a new transformation of memory as we know it. ${ }^{4}$

However varied such macro-historical narratives may be, they also have a great deal in common. First, they are relentlessly linear in their approach

\footnotetext{
* Research for this article was funded by an NWO VICI grant for the research project Tales of the Revolt. Memory, oblivion and identity in the Low Countries, 1566-1700, and with support of the IAP project City and Society in the Low Countries, 1200-1850.

1 Jacques Le Goff, Histoire et mémoire (Paris: Gallimard, 1988).

2 Pierre Nora, 'Between Memory and History. Les Lieux de Mémoire', Representations 26 (1989), 7-24.

3 Aleida Assmann, Erinnerungsräume. Formen und Wandlungen des kulturellen Gedächtnisses (Munich: C.H. Beck, 1999); Benedict Anderson, Imagined communities. Reflections on the origins and spread of nationalism (London: Verso, 1983); E.J. Hobsbawm, Nations and nationalism since 1780. Programme, myth, reality (1990; 2nd ed., Cambridge: Cambridge University Press, 1992).

4 See e.g. Elena Esposito, Soziales Vergessen. Formen und Medien des Gedächtnisses der Gesellschaft (Frankfurt am Main: Suhrkamp, 2002); Jeffrey K. Olick and Joyce Robbins, 'Social memory studies. From "collective memory" to the historical sociology of mnemonic practices', Annual Review of Sociology 24 (1998), 105-140.
} 
and work from the assumption that when new ways of approaching the past make their appearance, old ways of doing so will be discardedalmost as if there exists a finite capacity for engagement with the past in any one culture. Secondly, they usually posit an evolution of memory and memory practices away from the organic, local, traditional and communal, first towards the hegemonic nationalist memory cultures of the nineteenth and early twentieth centuries, and subsequently towards the hybridity and chaotic individuality of postmodern memory practices. The onset of this process is believed to have been enabled by the emergence of a new historical consciousness, a sense of difference between past and present, which is sometimes defined as a split between memory and history. ${ }^{5}$

Nevertheless, there is little agreement about the timeframe in which this development from pre-modern to modern memory takes place. For Esposito and Le Goff the seventeenth and eighteenth centuries are more important than they are for Hobsbawm and Anderson, who see most change happening from around 1800 . For Walter Benjamin it was the First World War that produced a great shift, while Nora seems to set the disappearance of the 'milieux de mémoire' in the very recent past. ${ }^{6}$ Despite this lack of consensus about the chronology, the sociologist Jeffrey Olick, surely one of the most astute of today's memory theorists, believes that one can glean from existing studies 'a fairly clear account of the rise of linear historicity out of the cyclicity of rural living and church eschatology'. He is persuaded by scholars who believe that the state had an important role to play in this process but also sees a role for the interest of 'publics' in the post-Renaissance. Moreover, he thinks that 'a rising sense of individuality' in the early modern period simultaneously created an awareness that the personal past was something 'that required preservation and recovery'. ${ }^{7}$ As far as Olick is concerned, a satisfactory paradigm about the history of memory is thus well within reach.

5 Matt K. Matsuda, The memory of the modern (Oxford: Oxford University Press, 1996), 11; Geoffrey Cubitt, History and memory (Manchester: Manchester University Press, 2007), 39-49; Mattei Calinescu, Five faces of modernity (Durham: Duke University Press, 1987).

6 See for a useful overview of these timeframes Olick and Robbins, 'Social memory studies' and Jeffrey K. Olick, The politics of regret. On collective memory and historical responsibility (New York: Routledge, 2007), chpt 9; Pierre Nora et al., Les lieux de mémoire, Bibliothèque illustrée des histoires (Paris: Gallimard, 1984-1992); on the indistinctiveness of the terms modern and premodern see Penelope Corfield, Time and the shape of history (New Haven: Yale University Press, 2007).

7 Olick, The politics of regret, $185^{-187}$. 
Even so, it is a striking feature of existing histories of memory that they are much better at describing what they consider to be new features of engagement with the past than in specifying what cultures of memory these replaced. In so far as current macro-historical theories consider pre-modern memory in any detail, they usually follow one of two strategies. The first, popular among scholars who work in cultural and literary studies, is to conflate pre-modern mnemonic theory, especially that of the ars memoriae first studied by Frances Yates in 1966, with actual memory practices in early modern European societies. ${ }^{8}$ Thus Elena Esposito, for instance, deftly combines the outcome of older research into Ramism and rhetoric, ars memoriae and the self, to arrive at a new grand narrative in which theories of intellectual change are soldered together to furnish an explanation of the modernization of memory. ${ }^{9}$

The second strategy is more common among social scientists and modernist historians, and relies for its evidence on grand narratives about other aspects of the coming of modernity, such as the discovery of the self, the rise of the print media and the public sphere, the impact of capitalism, and the emergence of the nation state, which are believed to have been accompanied by a new form of historical consciousness - it is the latter approach that Olick finds so persuasive. Since these narratives are interdependent, they create a plausible impression of coherence. From an early modernist perspective such an approach is, however, intrinsically problematic; early modernists have expressed doubts about the 'modernity' of each and every one of these phenomena and are therefore unlikely to accept the existence of the one as evidence for, or cause of, the emergence of the other. ${ }^{10}$

Both strategies actually have early modernist roots; they owe a great deal to the seminal work of Reinhardt Koselleck on early modern historical consciousness. Koselleck's classic essay Vergangene Zukunft was first published in German in 1964 and translated into English in 1985 as

8 On this strand, see Astrid Erll, Kollektives Gedächtnis und Erinnerungskulturen (Stuttgart and Weimar: J.B. Metzler, 2005).

9 Esposito, Soziales Vergessen.

10 Excellent summaries of the debates on modern vs. early modern nationalism in Anthony D. Smith, Nationalism (2001; 2nd ed., Cambridge: Polity Press, 2010); and Anthony D. Smith, Nationalism and modernism (London and New York: Routledge, 1998); see on the public sphere Craig Calhoun (ed.), Habermas and the public sphere (Cambridge Mass.: MIT Press, 1992); and on the self Roy Porter (ed.), Rewriting the self. Histories from the Renaissance to the Present (London: Routledge, 1997). See also Phil Withington, Society in early modern England. The vernacular origins of some powerful ideas (Cambridge: Polity Press, 2010). 
The Future Past. ${ }^{11}$ As Koselleck saw it, pre-modern historical consciousness could best be understood by considering how it related to the future. In his view pre-modern historical consciousness had two strands. First, there was the eschatological tradition, which approached time mainly as a period of waiting for the second coming of Christ and the end of time. In the course of the seventeenth century such eschatological notions of time lost much of their intellectual appeal. Secondly, there was the classical notion of history as magistra vitae, according to which topical knowledge about the past could be reapplied to new historical conditions. Modern historical consciousness, on the other hand, hinges on the perceived difference and distance between past and present, that is, on a sense of anachronism. This also has implications for expectations for the future; modern cultures expect novelty as a matter of course. Koselleck thought this form of consciousness was fundamentally new and had mostly emerged in what he called a Sattelzeit, a period of transition, lasting from $175^{\circ}$ to $185^{0}$.

Koselleck's essay has been tremendously influential among students of modernity. Yet while his essay was originally a contribution to the history of ideas and philosophy of history, his readers in the social sciences and cultural studies have tended to assume that his findings can be extrapolated to describe all of what we now think of as early modern memory culture. Hence Olick's assumptions about a 'rise of historicity' from the 'cyclicity' of rural living and church eschatology'. And hence also ideas like those of John Gillis who, when outlining a history of national memory in 1994, argued that in the pre-modern period only the elites had need of institutionalised memories; what there was by way of national consciousness in a place like late Tudor England, he believed, 'scarcely penetrated the consciousness of more than a small part of the population. Institutionalised forms of memory were too precious to be wasted on ordinary people', 12 who, in any case, 'felt the past to be so much a part of the present that they perceived no urgent need to record, objectify and preserve it'. ${ }^{\prime 3}$

11 R. Koselleck, Vergangene Zukunft. Zur Semantik geschichtlicher Zeiten (1964; Frankfurt am Main: Suhrkamp, 1979).

12 John E. Gillis, 'Memory and identity. The history of a relationship', in John R. Gillis (ed.), Commemorations. The politics of national identity (Princeton N.J.: Princeton University Press, 1994) 3-24, there 7 .

13 Ibid., 6. 
To early modernists, such a dismissal is clearly unsatisfactory; an evergrowing number of scholarly studies demonstrates how much richer and more complex were forms of engagement with the past before 1800 . At the same time, early modernists have so far not offered anything like an alternative view on what, if anything, might constitute the similarities and differences between early modern and modern memory. This introduction will, first, highlight and summarise what the insights presented in the individual chapters of this volume can contribute to such an alternative view. Yet we also aim to show what the study of early modern memory practices has to offer to the field of memory studies and the history of memory as a whole. We have, therefore, organised the essays consciously around three themes that play a central role in the field of memory studies: the politics of memory, mediality and personal memory. We believe that in each of these areas, early modernists have much to learn from modern memory studies. Yet conversely, we will also argue that early modern practices shed an unexpected light on many scholarly assumptions about the modernity of modern memory.

\section{Memory Politics and Memory Wars}

Most studies of memory politics have concerned themselves with the period after around 1800, when nationalism was in its heyday and traditions were being invented thick and fast. Undeniably this was the era of huge history paintings, of monuments and museums, of national days of commemoration and of state-sponsored history curricula. Using the new mass media ranging from schoolbooks, stamps and street names to film and radio, many states since 1800 have manipulated and controlled versions of the past to suit their own political agendas. ${ }^{14}$ In the European states in which this form of memory politics originated, it now seems to be past its prime, although in former Soviet Republics, for instance, states still have a high stake in controlling the past. But governments are not the only agents who deploy memory for political purposes. In most democracies today, many non-state actors are involved in the politics of memory,

14 Following the influential agendas set by Anderson, Imagined Communities; E.J. Hobsbawm and T.O. Ranger (eds.), The invention of tradition (Cambridge and New York: Cambridge University Press, 1983). Ernest Gellner, Nations and nationalism (Ithaca N.Y.: Cornell University Press, 1983); Anderson, Imagined communities; Hobsbawm, Nations and nationalism. 
to fashion and strengthen identities, to demand a place for memories of particular groups or events in the public domain, and to right past wrongs. These actors, too, of course avail themselves of new mass media.

Yet neither the nation state, nor democracy or mass media are required for memory to become a political issue. In late medieval cities, it was customary, for instance, to commemorate instances of deliverance from danger, or urban victories, with annual processions, which were often accompanied by sermons. Thus the city of Amsterdam instituted an annual procession to commemorate its suppression of an uprising of Anabaptist radicals in $1534 .{ }^{15}$ But secular forms of public memory also existed. From 1528, when it was defeated by neighbouring Holland, the city of Utrecht was obliged annually to send a pig to The Hague as a sign of submission; to keep the memory of Utrecht's humiliation alive, the pig was first exposed to the mockery of the crowds in The Hague before being slaughtered. ${ }^{16}$ Long before nineteenth century and before the advent of nationalism, memory was already a deeply political matter on all levels of early modern European society.

On the most basic level, this was so because almost all early modern claims to rights or authority were also claims about the past. On the whole, early modern people believed things to be true or legitimate only if they could also be proven to be old. Even when no longer claiming ancient Roman or Trojan ancestry, as had been common in the Middle Ages, princes presented themselves visually, ritually and in texts as the scions of ancient houses and the descendants of valiant and saintly ancestors. In terms of asserting social status, as well as establishing degrees of kinship, a knowledge of lineage was highly desirable. At the top end of society, heralds came to act as arbiters of descent, lineage and nobility, and by the early sixteenth century noble families were likely to use a whole range of media to commemorate their achievements, by having themselves depicted as 'founders' of altars and hospitals or by commissioning chapels, fountains and funerary monuments as well as genealogies, paintings of their ancestors and family chronicles. ${ }^{17} \mathrm{~A}$ craze for medals spread both portraits and memories of memorable political events across Europe along with

15 Femke Deen, Moorddam. Publiek debat en propaganda in Amsterdam tijdens de Nederlandse Opstand, doctoral thesis University of Amsterdam (2012), 41, 81.

16 J.J. Dodt van Flensburg, Archief voor kerkelijke en wereldsche geschiedenissen, inzonderheid van Utrecht, 7 vols. (Utrecht, 1838-1848), vol. 6, 79 .

17 Bernard Guenée, Histoire et culture historique dans l'Occident médiéval (Paris: Aubier Montaigne, 1980) chpt. 8; Daniel Woolf, The social circulation of the past. English historical culture, 1500-1730 (Oxford: Oxford University Press, 2003), 73-137. 
printed accounts of royal weddings and funerals. If early modern rulers often preferred to dress up change as continuity, they could also be innovative in doing so. In late Tudor and early Stuart England, for instance, the authorities used the inclusion of new commemorative events on the calendar, like Accession Day and Guy Fawkes Day, to develop a strong new memory culture around the advent and blessings of Protestant rule. ${ }^{18}$ In the wake of the Reformation the Catholic Church buttressed its own historical claims with the latest findings and techniques of philologists and antiquarians. ${ }^{19}$

Yet memory politics was never just a matter for princes and churches. Even in small village communities knowledge about the past was of vital political importance. This was true, for instance, when it came to proving local grazing rights on common land, parish boundaries, the level of tithes or the limits to seigneurial power. If they were to stand any chance in courts of law, communities needed to mobilise collective knowledge about the past, and they did so quite effectively. ${ }^{20}$ In cities corporate groups would back up legal and political claims with references to documents and charters as well as witness statements. How important this documentary evidence could be can be seen in Alexandr Osipian's chapter about the Armenian minority of the city of Lemberg, whose political conflict with the ruling Catholic majority was fought out mainly through medieval charters. In the new political context that emerged with the PolishLithuanian Union of 1569, the Armenians quickly seized on the possibility of appealing to charters of medieval Ruthenian princes, which could now legitimately be presented as relevant to the status quo. Yet in retribution, the Catholics seized on the Ruthenian connection to prove that the Armenians had once upon a time collaborated with the Tatar enemies of Poland and were thus old enemies of Lemberg. Several decades passed

18 David Cressy, Bonfires and bells. National memory and the Protestant calendar in Elizabethan and Stuart England (London: Weidenfeld and Nicolson, 1989).

19 Katherine van Liere, Simon Ditchfield and Howard Louthan (eds.), Sacred history. Uses of the Christian past in the Renaissance World (Oxford: Oxford University Press, 2012).

20 Andy Wood, 'The place of custom in plebeian political culture: England, 1550-180o', Social History 22 (1997) 46-6o; Andy Wood, The politics of social conflict. The peak country, 1520-1770 (Cambridge: Cambridge University Press, 2003); Adam Fox, 'Remembering the past in early modern England. Oral and written tradition', Transactions of the Royal Historical Society 6th series 9 (1999), 233-256; Ralf-Peter Fuchs, 'Erinnerungsschichten: zur Bedeutung der Vergangenheit für den "gemeinen Mann” der Frühen Neuzeit' in R.P. Fuchs and W. Schulze (eds.), Wahrheit, Wissen, Erinnerung. Zeugenverhörprotokolle als Quellen für soziale Wissensbestände in der frühen Neuzeit (Münster: Lit, 2002). 
before the Armenians found a suitably documented alternative to salvage their rights. The Lemberg case teaches us that pre-modern views of the past were rarely static; in fact, precisely when the past is politically authoritative, it falls subject to constant reinvention.

In early modern Europe not only legal and political but moral claims as well had to be upheld with references to the past. Protestant and Catholic theologians battled out their differences over issues like the customs of the early Christians, to which Protestants claimed to be 'returning'. ${ }^{21}$ But the more recent past could also become highly contentious. Jasper van der Steen's chapter shows that very soon after the Reformed church of the Dutch Republic began to divide over the theological issue of predestination in the early seventeenth century, the contestants in this quarrel started to support their truth claims with reference to events of the Dutch Revolt of the 1570 s and '8os, appealing as a precedent for correct religious thought to the views of its leader, William of Orange, who had been murdered in 1584. By the time the orthodox wing of the Reformed church could declare victory, in 1618-19, the conflict had generated a new tradition in Dutch politics in which references to the Revolt were used as a benchmark, not only when talking about the Spanish enemy but also in internal political polemics. A century later, as Ulrich Niggemann shows, it was no different in England, when the newly emerging Whig and Tory parties quarrelled about the true nature of the Glorious Revolution of 1688 , not only with a view to appropriating its legacy but also to defining the nature of legitimate politics. In the process, the fact that both sides used the Revolution as their frame of reference promoted the acceptance of the Revolution settlement itself. Like Van der Steen, Niggemann thus shows the importance of conflicts and memory wars for establishing the status of an event in a 'canon' of the collective past.

Implicitly, Niggemann and Van der Steen's chapters also bear out an interesting point made by Sean Dunwoody, who argues in his chapter about the 'Calendar War' in sixteenth-century Augsburg that while memories of a local 1584 uprising became immensely contested, the coexistence of different versions of the past also helped to keep the peace. Even though Augsburg's authorities had felt very much threatened by the rebels' religious reading of what the magistrates insisted had been a simple political measure, the social structure of sixteenth-century Augsburg also

${ }^{21}$ Van Liere, Ditchfield and Louthan (eds), Sacred History; Bruce Gordon (ed.), Protestant history and identity in sixteenth-century Europe, 2 vols. (Aldershot: Ashgate, 1998). 
accommodated the existence of counter-memories among a minority within the city. Early modern authorities might go a long way in trying to propagandise and assert their version of past events, yet even in the densely governed early modern city there were very clear limits to the ability of rulers to control memories. ${ }^{22}$ In practice early modern power was never absolute. Even when ruling elites used gruesome levels of violence to eradicate rebellion, as in the 1514 peasant rebellion in Hungary analysed in Gabriella Erdélyi's chapter, rebel memories resurfaced in the public domain to coexist with the graphic memories of noble violence against the peasant rebels.

It is precisely because memory was politically so important and potentially explosive that many pre-modern societies also experimented with acts of oblivion. Formal agreements to forget the past were a frequently used political instrument until well into the nineteenth century, especially after civil wars. As late as 1946, Winston Churchill invoked Gladstone's proposal to have an 'act of oblivion' for Ireland and suggested that something of its kind was necessary if postwar Europe was not to descend into war again. As Ross Poole has pointed out in a 2009 article, such acts of oblivion seem a rather problematic political instrument. First there is the practical problem of how one can police such injunctions to forget. Secondly, their legal application contains a paradox. After all, to assess whether something can or cannot fall within the meaning of the act, a legal system has to have knowledge of the things that it is supposed to forget. So what did such acts actually try to achieve? Poole's analysis offers a persuasive answer. The point was less to prevent people from knowing about the past than to demand that they not act upon that knowledge. Memory, as Poole sees it, is knowledge with implications for the present that offers an agenda, even an imperative, to act. Acts of oblivion deny past events as legitimate reasons for action in the present and isolate them as being of the past. ${ }^{23}$

It is in this vein, certainly, that oblivion seems to have been implemented after the French Wars of Religion. The policy of oubli that was legally imposed in the 1598 Edict of Nantes seems to have worked well

22 See for a nice example also Jelle Haemers, 'Geletterd verzet, diplomatiek, politiek en herinneringscultuur van opstandelingen in de laatmiddeleeuwse en vroegmoderne stad (casus: Brugge en Gent)', Bulletin de la Commission Royale d'Histoire 176 (2001) 5-54.

23 Paul Connerton, 'Seven types of forgetting', Memory Studies 1 (2008) 59-71; Ross Poole 'Enacting oblivion', International Journal of Politics, Culture and Society 22 (2009) 149-157, there 149-153. 
in the sense that conflicts about the past could not become a trigger for new rounds of violence. But as Philip Benedict shows in his chapter, the two parties to the conflict who had not been decisively defeated could nevertheless develop and sustain a polarised historical view of events throughout the seventeenth century; only the defeated supporters of the Holy League did not succeed in commemorating their version of events. Instead the winners ended up representing the religious motives of the defeated League as a disguise for self-serving noble ambitions, a view with which all in seventeenth-century France could painlessly agree.

The politics of memory in early modern Europe were 'early modern' in the sense that the past as a ground for moral and political legitimacy was more or less uncontested; challenges to authority had to be made through a reinvention of the past. Yet in other respects the memory politics of early modern Europe were much more modern than is often acknowledged. They were the elaborate, ubiquitous, and highly flexible product of many agents and enjoyed importance on all levels of society. The political importance of particular memories might be limited to the local or regional levels, to a corporation or a minority, but there are also many examples of powerful 'national' memory cultures emerging, with or without central state intervention. And as we will see below, memory cultures could also come to include the politics of victimhood.

\section{Mediality}

The spread of mass media has in many ways transformed the nature of memory. It is undeniable that over the last two centuries it has become possible to reach many more people at once, through print, radio and film, through schoolbooks and television programmes, and not least through the internet. Yet what qualitative implications does this media profusion have for the practice of memory?

One of the most striking aspects of early modern local memory is that it was, or could be, a truly multimedia affair. The studies in this volume draw our attention to the vast range of media, objects and spaces that could be used as carriers of memory, ranging from a half-burnt rudder and a piece of peat in Marianne Eekhout's study of the commemoration of the capture of Breda in 1590 to the eighteenth-century Irish mummers' plays evoking Oliver Cromwell which are described by Sarah Covington. Local authorities were often prime initiators or at least sponsors of the annual commemorations of great victories and instances of deliverance and of 
the appearance of inscriptions and monuments in public places. Yet there were many other stakeholders in the perpetuation of memories.

Marianne Eekhout's chapter shows that soldiers and officers did much to spread memories of Breda's relief in 1590 across the Dutch Republic; the medals and other commemorative objects that were awarded to combatants were passed down through generations and remediated, for instance in portraits. The Gaelic population of Ireland, often illiterate, did not lack the means or the media to commemorate the evil days of Oliver Cromwell. Covington draws attention to their use of the Irish landscape as a site of memories, evoking not only displacement and dispossession but also resistance; rocks had rescued people and ravines had sent enemies to their death. And it was not just warfare that was commemorated. Jasmine Kilburn-Toppin shows how the medieval memoria tradition of London crafts guilds continued to thrive even after the Reformation had put an end to the guild's intercessory role for the souls of its deceased members. London craftsmen continued to ensure that they would be remembered for their skills and craftsmanship by presenting guild halls with specimens of their crafts or tools of their trade, while many others also preserved the memory of their membership by gifting objects for use in guild rituals. The guild halls thus became repositories of memories of individual members as well as the collective skills and history of the guild.

When we add up the evidence of ballads and medals, plays and gable stones, stained glass and sermons, rocks and ruins, street names and processions, not to mention family tales and rituals, it seems clear that on a local level early modern memories could be as ubiquitous and pervasive as they are at any time in the twenty-first century. This phenomenon was never just the result of one-way traffic; many agents were involved in the shaping and transmission of early modern communal memories. When we look carefully, we can see that many such memories resemble each other; many early modern memories seem to fit familiar narrative schemes. They have quite similar heroes and villains and may follow Biblical patterns or folkloric motifs. In her chapter, Erika Kuijpers highlights that whereas early printed histories of the Dutch Revolt privileged narratives of victimhood and self-sacrifice, in the stories which were passed on orally there was far more space for the picaresque, acts of violence, laughter and cunning. Covington notes that tales about Cromwell and his men were premediated by tales of earlier episodes of sacrilege and destruction. The same was true for the martyrologies discussed by Dagmar Freist in her article. The narratives of early modern martyrs could be authentic while at the same time being each other's spitting image. 
When we started work on memory, we were inclined to think of this pre- and remediation of memory as an early modern phenomenon, which fitted the anachronistic mind-set of pre-modern people. Yet among students of modern memory there has also been much interest recently in the pre- and remediation of memories. When modern people remember, too, their memories are often shaped by existing images and narratives. Thus, it seems that when British soldiers described their experiences in the First World War, they frequently did so in imagery that they borrowed from John Bunyan's Valley of the Shadow of Death. People in the French Cevennes modelled memories of World War II on older tales about the Calvinist resistance to the French State in the late seventeenth century, which, in turn, echoed the Biblical plight of the Jews in Egypt. Film and television have an enormous power to shape memories, but in doing so, they tend to invoke existing imagery, some of it surprisingly old. Astrid Erll gives the example of the iconic image by Richard Drew of the man falling from the Twin Towers on $9 / 11$ and argues that this image attained iconic status because of the abundant pre-existing notions about falling angels and the fall of man. ${ }^{24}$ Modernity has thus not put an end to the pre-modern cultural habitus of describing new things with reference to past examples.

In an influential 2009 book Michael Rothberg coined the term 'multidirectional memory' to describe the way in which memories of slavery and the Holocaust have affected one another. He shows how many times philosophers, filmmakers, novelists, and others have presented memories of slavery as a pre- or remediation of the Holocaust, and vice versa. Rothberg thinks of this as a new phenomenon that has been enabled by the development of modernity and the mass media. ${ }^{25}$ Yet once more there seem to be parallels with early modern examples. In her chapter, Dagmar Freist draws attention to the way in which the Spanish treatment of the 'Indians' in the New World became part of the European imaginary as a model of cruelty. In the 1560 and 1570 os Dutch rebel pamphlets warned that the advisers of their overlord, the King of Spain, were clearly

24 Astrid Erll, Memory in culture, transl. Sarah B. Young (Basingstoke: Palgrave Macmillan, 2011) 139-143; David J. Bolter and Richard Grusin, Remediation. Understanding new media (Cambridge Mass.: MIT Press, 1999); Astrid Erll and Ann Rigney (eds.), Mediation, remediation and the dynamics of cultural memory (Berlin and New York: De Gruyter, 2009); see for the Cevennes example Philippe Joutard, La légende des Camisards. Une sensibilité au passé (Paris: Gallimard, 1977).

25 Michael Rothberg, Multidirectional memory. Remembering the Holocaust in the age of decolonization (Stanford: Stanford University Press, 2009). 
intending to treat them 'as they had the people of the New World', and presented themselves as the Indians of Europe, the innocent victims of power-hungry tyrants. Once having established this parallel, the Dutch could present their colonial ventures in the Americas as a form of rescue mission for American Indians, who would be liberated by the West India Company in the same way in which the Dutch had liberated themselves from their overlords. ${ }^{26}$

Phenomena such as the Black Legend about Spain are reminiscent of what Daniel Levy and Natan Sznaider have called cosmopolitan memory.

cosmopolitanism refers to a process of 'internal globalisation' through which global concerns become part of local experiences of an increasing number of people. Global media representations, among others, create new cosmopolitan memories, providing new epistemological vantage points and emerging moral-political interdependencies. ${ }^{27}$

Levy and Sznaider see the advent of the cosmopolitan memory of the Holocaust as the result of a 'decoupling of collective memory and the nation state' and as a new phenomenon that belongs to a more 'global' era of human development. Yet, as Freist points out, when we broaden the chronological perspective we can see that 'cosmopolitan memories' of the type discussed by Daniel Levy and Natan Sznaider with reference to the Holocaust actually emerged well before the advent of the nation state. Levy and Szaider do in fact note that religious solidarities had, of course, always created their own form of cosmopolitanism, but they have not considered historical parallels before 1800 in any detail. Freist draws attention to the confessional diasporas, including the transnational interest in martyrdom and mission cultures. For earlier periods we might think of the crusades. ${ }^{28}$

It may seem perverse to compare such deeply partisan and polemical uses of memory with the cosmopolitan memories of the Holocaust and the new standards for good and evil that these seem to have set across the

26 See on this issue also Benjamin Schmidt, Innocence abroad. The Dutch imagination and the New World, 1570-1670 (Cambridge: Cambridge University Press, 2001).

27 Daniel Levy and Natan Sznaider, 'Memory unbound. The Holocaust and the formation of cosmopolitan memory', European Journal of Social Theory 5 (2002), 87-106.

28 Nicolas Paul and Suzanne Yeager (eds.), Remembering the crusades. Myth, image and identity (Baltimore: Johns Hopkins University Press, 2012); Nicholas Paul, To follow in their footsteps. The crusades and family memory in the high middle ages (Ithaca and London: Cornell University Press, 2012). 
globe. Still, the parallel is not really so far fetched because as time went on, after all, it was some of these Protestant memories which morphed into lieux de mémoire for the Enlightenment. In the eighteenth century, memories of the Inquisitions, for instance, outgrew the context of confessional solidarities to become the exemplars of obscurantism and the bugbear of all those striving for freedom of thought and speech, and they have remained so until today.

That cosmopolitan memories might undergo considerable change and loss of meaning is borne out by the essay of Benjamin Schmidt, who charts the ways in which geography created global memories of 'memorable matters' in far-flung places. Deriving their authority from alleged eye-witness accounts of individual travellers, such memories were transmediated and reshaped to serve a variety of purposes, not least commercial ones. Moving from print to pottery, from wallpaper to cabinet, the iconographical motifs ultimately derived from the 'memories' of travellers could become constituent for European convictions about the Asian world-for instance about the total control which 'oriental' rulers exercised over the bodies of their subjects-while simultaneously also changing meaning as they moved from medium to medium and from paper to bedroom decorations.

All in all, we can conclude that the difference which mass media have made to memory is really one of scale, rather than of the mechanisms by which memories are shaped and mediated. Now, scale certainly matters; it has, indeed, enabled modern states to go much further than before in trying to engage subjects in a vision of the past that suits their current political objectives; it also enables the spread of a greater variety of views of the past. Yet in a qualitative sense, it seems fair to say that early modern societies had both the means and the motives to shape and celebrate collective memories and did so with enthusiasm. Moreover, it is also clear that memories moved and were transmediated across space with considerable ease.

\section{Personal Memory}

Recent developments in modern neurosciences have led to new insights into the process of memory formation. Modern psychology describes 'personal episodic memory formation' as a process of continuous selection and adding meaning, a process that starts during the experience and is again 
at work every time the memory is narrated in the course of a lifetime. ${ }^{29}$ The recall of an event or experience always comes with new meanings added to it. Today's psychologists therefore define remembering no longer as retrieval of stored data but as a cognitive construction of a new reality which involves the activation of existing neuronal structures. Memories are flexible at the moment they come to our mind. During the process of remembering our brains also take care of the contextualizing, the solving of inconsistencies and so forth. New ingredients may be added: associations with people, other experiences, emotions, explanations, reasons and motives, the importance of what happened. The main goal of this processing of memories is to give memories reliability to oneself and one's audience, to enrich them with extra meaning and to strengthen them. ${ }^{30}$

Yet whereas the need to organise, interpret and narrate memories seems universal, the way people do this - the when, where, what and how-is socially, culturally and thus historically determined. To what extent did early modern memories differ from our own? In some respects, personal memory seems to have operated in ways quite similar to our own. Thus, people in early modern Europe were well aware that the elderly could recall events from their youth much more vividly than the things they had experienced at a later age. Like today, people in early modern Europe found it important to know something about their families. To be without knowledge of one's kin had practical disadvantages in a society in which kinship determined not only whom one might marry but also one's status. Emotionally, as well, there are indications that people felt that something was amiss if one had no knowledge of the family past. Frederik van der Moelen, who had left home at age eleven and had returned to find all his kin deceased, was clearly troubled by his lack of family history; in 1545 he made his son Pieter record the bits of information Frederik heard from people who had known his kin. ${ }^{31}$ As is the case today, women were often

29 Episodic memory refers to 'the individual's conscious memory of events and experiences in which he or she has been personally involved'. Geoffrey Cubitt, History and memory (Manchester: Manchester University Press, 2007), 68; see also U. Neisser and Lisa K. Libby, 'Remembering life experiences', in Endel Tulving and Fergus I.M. Craik (eds.), The Oxford handbook of memory (Oxford: Oxford University Press, 2005) 315-332, esp. 316.

30 Siegfried J. Schmidt, 'Memory and remembrance. A constructivist approach', in Astrid Erll, Ansgar Nünning, Sarah B. Young, (eds.) Cultural memory studies. An international and interdisciplinary handbook (Berlin and New York: De Gruyter, 2008), 192.

31 O. Schutte, 'De familiekroniek van der Moelen', in: E.C. Dijkhof and M.J. van Gent (eds.) Uit diverse bronnen gelicht. Opstellen aangeboden aan Hans Smit ter gelegenheid van 
the best sources of family knowledge. ${ }^{32}$ The chapter by Katharine Hodgkin shows how elite women in seventeenth-century England took it upon themselves to record the family histories for their children. The fact that families rise and fall, and continuity is always threatened by misfortune, illness and death perhaps explains why these women were so concerned with preservation and commemoration, and also why their records are marked by recurrence of events and a sense of time that seems indeed rather cyclical. Yet while these women figured as custodians of the family past, they were not concerned only with importance of lineage and their family's connection to place and continuity. Their family histories were also connected with national history and God's plan for England. It was not family links alone that were constitutive of personal identity. Jasmine Kilburn-Toppin shows how important it was for London guildsmen to commemorate their skills and membership of the artisan community. For sixteenth-century Ghent chronicler Jan de Rouck being a guildsman also involved commemorating his family's tradition of rebellion against their overlord. ${ }^{33}$

While some early modern memory practices thus seem quite familiar to us, others reveal significant differences with modern behaviour. That is partly because recording personal memories was not self-evident. Writing history, including writing down one's personal memories, is a social act that is highly determined by social and cultural conventions. Literacy was limited in early modern Europe and the writing of memoirs not a widespread activity. The social biases in early modern source material are thus certainly more pronounced than in contemporary evidence. Yet, the five studies in the last part of this volume make use of early modern texts by a large and socially fairly heterogeneous group of non-literary authors: women, priests, nobles, antiquarians, chroniclers, diarists, genealogists and self-styled historians, all of which may contain personal memories and eye-witness accounts. Although most of these texts have remained in manuscript until the nineteenth or twentieth centuries, or even until today, they were usually not meant to be private nor personal; the reflective introspection that characterises so many modern so-called ego-documents is rare in the early modern diaries of non-literary authors. Many indeed do not seem to be very personal at first sight, just a list of facts and data,

zijn vijfenzestigste verjaardag (Den Haag: Instituut voor Nederlandse Geschiedenis, 2007) $293-307$.

32 Woolf, The social circulation of the past, 116.

33 Haemers, 'Geletterd verzet'. 
and only now and then coming out with standard phrases about God's punishments and the wickedness of mankind. As Yuval Harari has put it: sixteenth-century memoirs and chronicles are 'made of facts rather than of experiences'. ${ }^{34}$ We believe, nevertheless, that personal memory essentially functioned as it does today: creating identities by connecting oneself to a meaningful and shared past. These texts, as terse as they may seem to us, must have been meaningful to their authors and their audiences and although the interpretation of this type of source material is far from straightforward, records like these are our best evidence for finding out how individuals related to the past.

When interpreting such texts, we see three interrelated variables at work that determine the content of personal memories: first, the author's frame of reference such as his or her knowledge, presuppositions, concepts etc.; second, the cultural practices or the way people 'do memory' (i.e. rules of genre, narrative templates, topoi, rituals, language, expression etc.); and third, their functionality, that is, the psychological, social, political aims and needs for which memory is instrumental.

Obviously the frame of reference of sixteenth- or seventeenth-century writers is different from our own. They will deploy other concepts of good and evil, truth and relevance; they also differ in their knowledge and beliefs about nature and the cosmos and have other ideas about the meaning of life, the divine and the hereafter, about society and social order, about justice and authority. These notions and normative frameworks lead to memories that do not correspond with what we would have observed had we been present at the described event. Until the mid-seventeenth century many authors incidentally report on supernatural phenomena and interpret these as divine signs. More generally, divine providence was omnipresent in early modern experiences. And whereas in our perception, fear is a psychological reaction to stress or danger, the fear experienced by the authors discussed in the chapter by Andreas Bähr derives from an exterior source; divine intervention determines whether they are struck by fear or experience fearlessness.

Such conceptual differences are the most pronounced in the way authors write about what were presumably distressing and disorienting events. Modern Western middle-class society has a strong tendency to psychologise the effects of individual emotional experiences. In early modern

34 Yuval Noah Harari, Renaissance military memoirs. War, history, and identity, 1450-160o (Woodbridge: Boydell Press, 2004), 67. 
Europe people saw their memories very much as an archive of factual data about the past, and it was rare for an individual to explicitly connect these memories to his or her own identity. For us, memories tell us who we have become through past experiences. We structure our autobiographies in terms of a personal development that is marked by what we have lived through. In early modern autobiographical sources, however, the self is more connected to the body and bodily experiences and defined in terms of membership of family or community. In early modern histories and chronicles the individual's life is a function of the religious or civil community to which he or she belongs, and part of a greater design that is beyond the author's own control. Every person will go through the given stages of childhood, adolescence and adulthood; he or she will encounter fortune or misfortune but will not change fundamentally.

It is therefore quite possible that we do not always recognise memories of loss for what they are, because they are expressed in ways that seem unfamiliar to us. Whether or not people write in emotional language is a question of genre and conventions as well as the identity of the author. Susan Broomhall shows in her chapter that violent and distressing experiences can be recorded in many ways and in a wide range of documents, yet the expression of emotions is bound to the rules or conventions of genres as well as to the identity of the author. Thus, lamentations and ostentatious grief could be expressed by Catholics in connection with the devastations to the Church caused by Protestants and fellow Catholics. Such lamentations could be seen as an act of devotion and fitted in narratives of suffering and martyrdom for the true faith. Yet the emotions that individuals are likely to have experienced in situations that threatened their own lives were more problematic to talk about. Various authors describe their own feelings through the eyes of others, in some cases a fictive narrator, or they restrict their descriptions of distress to the expressions of anonymous others. Charlotte Arbaleste, who for her son recorded the life of her husband, a prominent Parisian Protestant, did not explicitly write about her own feelings, except on the one occasion when she feared that her daughter would be slaughtered before her eyes. At that point she momentarily felt despair. Yet this passage serves a pedagogical purpose in her account; the moral lesson to be learned was that despair is a sin as it implies a loss of faith. One should always trust in God's plan.

More common in many chronicles and records of the time of the religious wars is a tendency to create order through classifications and detailed descriptions of things lost. In many chronicles we find the enumeration of material losses including the assessment of their financial 
value. Convent communities, especially, produced many such texts in the hope that restitution could be claimed somewhere. But as terse as these inventories may be, they are emotionally charged and may have served the task of spiritual recovery from traumatic loss. From modern psychological literature on Post-Traumatic Stress Disorder (PTSD) it becomes clear that adding meaning and order to traumatic memories helps prevent mental disorders by connecting cognitive data to physical and emotional memories, creating distance in time and place between the event and the moment of retrieval. The very act of writing is thus an effective way of coping, whether or not emotions are expressed in a way familiar to us. ${ }^{35}$ Moreover, the articles by Broomhall, Bähr and Hodgkin show that early modern authors were culturally very well equipped to give meaning to their experiences of suffering, probably better so than many people in the West nowadays. Early modern Christianity, which put so much emphasis on the benefits of suffering and sacrifice and on a providential God, offered a framework in which many people apparently managed to make sense of experiences and thus to cope with them in ways that helped them to move on. Modern psychologists say there are people who are capable of turning traumatic memories into what they term 'personal growth'. ${ }^{36}$ Although no early modern person would have described the process in that way, the notion that spiritual growth was to be had from a terrible experience was widely available as a cultural model.

A good example is given by Andreas Bähr in his account of Jesuit Athanasius Kircher, who was saved from being hanged by attackers when he overcame his fear and was spiritually prepared for martyrdom. Bähr

35 In modern medical practice, autobiographical writing is used as therapy: Charles M. Anderson and Marian M. MacCurdy, Writing and healing. Toward an informed practice (Urbana Illinois: National Council of Teachers of English, 200o); Louise A. DeSalvo, Writing as a way of healing. How telling our stories transforms our lives (Boston: Beacon Press, 200o); Judith Harris, Signifying pain. Constructing and healing the self through writing (Albany N.Y.: SUNY Press, 2003); Matthew D. Lieberman and others, 'Putting feelings into words. Affect labelling disrupts amygdala activity in response to affective stimuli', Psychological Science. A Journal of the American Psychological Society / APS, 18 (2007), 421-428; Crystal L. Park and Carol Joyce Blumberg, 'Disclosing trauma through writing. Testing the meaningmaking hypothesis', Cognitive Therapy \& Research 26 (2002), 597; Mary Beth Williams, and Soili Poijula, The PTSD workbook. Simple, effective techniques for overcoming traumatic stress symptoms (s.l.: New Harbinger Publications, 2002).

36 Nigel C. Hunt, Memory, war and trauma (Cambridge: Cambridge University Press, 2010), esp. chpt. 6; Barbara Lieberei and Michael Linden, 'Overcoming hurting memories by wisdom and wisdom psychotherapy', in Michael Linden and Krzysztof Rutkowski (eds.) Hurting memories and beneficial forgetting. Posttraumatic stress disorders, biographical developments, and social conflicts (Oxford: Elsevier, 2013), 165-179. 
underlines how often both Catholics and Protestants describe their fear as something of the past. A truly faithful person will trust God and so overcome fear. Similarly, converts might evoke the sinfulness, pain and misery they had experienced in their unconverted state, or in the process of conversion itself, but only because this state could be contrasted with their newly converted persona. Martyrdom, a death suffered for steadfast belief in the right cause, was considered deeply edifying. One's personal fate on earth is of secondary importance to those who believe that suffering is a test and that redemption will follow hereafter. Many chroniclers report the triumph of good over evil and the restoration of the true church, law and order or social structures.

Of course, very few victims of the atrocities of early modern warfare would write their memoirs. ${ }^{37}$ Susan Broomhall suggests that victims tended to evoke memories mainly if there was some secondary gain to be achieved by doing so and/or if their experiences could be given some sort of transcendent significance. A possibility of compensation might trigger emotive descriptions of war experiences, for instance. The benefits might also come from the status which some memories conferred. Apart from religious merits these benefits could also derive from a reputation for heroism or cleverness as we can see in the many seventeenth-century family stories which recounted how ancestors outwitted the enemy, made a miraculous escape, or were delivered from great danger. A community or a family as a whole could benefit from the pious or heroic deeds and martyrdom of ancestors or from the blessings that were bestowed on their leaders or ancestors. Thus the descendants of the exiles described by Johannes Müller could claim to be particularly pious because their ancestors had fled their homes for the godly cause. Yet their exile identities did not necessarily distance them from the host society to which they had fled. On the contrary, their exile past legitimised their presence in the host society and could easily be combined with the new local identities they embraced. Identification with the local society and even with the local past could perfectly be coupled with the cultivation and reinvention of the exile narrative and identity. Müller's study of exiles shows that early modern people had multiple identities, just as they do today.

37 Erika Kuijpers and Judith Pollmann, 'Why remember terror? Memories of violence in the Dutch Revolt', Micheál O'Siochrú and Jane Ohlmeyer (eds.), Ireland 1641. Contexts and reactions (Manchester: Manchester University Press, 2013) 176-196. 
Other ways of matching memories and identity are discussed by Brecht Deseure and Judith Pollmann. They argue that even if it was common for early modern people to see the past repeat itself, this did not mean that they did not have a 'sense of change'. Examining two chronicles for what they can tell us about the impact of rupture on historical consciousness, Deseure and Pollmann show that major crises did have a clear impact on the way in which people experienced the relationship between past and present. Yet they also argue that such an impact did not have to last. Rather than to admit to having changed themselves, early modern people might also reinvent the past to suit their needs in the present.

\section{Conclusion}

There are important differences between the ways in which early modern and modern European people remembered the past. In a political, legal and moral sense, the past was more important in early modern Europe because as a source of authority it had few competitors; notions of universal or natural law existed but were normally paired with, and expected to give way to, precedent. With the exception of technological changes, which were widely praised, there was little sense of progress as an end in itself. Perhaps the most common alternative to using precedent was to point to divine intervention - the providential, sacred or miraculous could sometimes match or override the authority of the past. Once we realise this, it is no wonder to discover that even without the nationalist agendas of nineteenth-century Europe, memory was of extreme political importance on all levels of society and that the reinvention of the past, with or without scholarly support, was a well-established practice. In this sense, when reinventing memory politics for national agendas, modern nation states could build on a tradition that was already very well established. Moreover, important elements in this tradition have in fact survived the nationalist phase in the history of memory. In modern secular societies the status of the past is obviously different from what it was in early modern Europe; references to universal rights are the order of the day, 'development' and innovation are considered positive values, and the sacred has lost most of its public explanatory power. At the same time, the new forms of legitimation coexist with the much older use of the past as a source of authority. Historians have learned to frown on anachronism, but the rest of society constantly invokes the past for lessons and parallels. 
When practicing memory early modern Europeans availed themselves of an enormous range of objects and artefacts and features in the landscape, which could attain long-term significance as mnemonic markers as long as there were people to tell tales associated with them. Written, visual, ritual and performative media interacted and reinforced one another, creating ubiquitous memory cultures on a local level and sometimes even beyond. Both before and after 1800, memories were pre- and remediated. Moreover, even before mass literacy, cheap print, radio and television, memory was already a multimedia affair. In terms of mediality, the differences between modern and pre-modern memory are mainly ones of scale. Scale matters immensely when it comes to the use of memories as a tool to mobilise people and resources for the national or large-scale ideological and military undertakings that marked the nineteenth and twentieth centuries. But an awareness of early modern memory practices helps us recognise that side by side with such large-scale memory projects, other ways of doing collective memory persisted. There is an uncanny resemblance between early modern memory practices and those of many post-national memory cultures. Phenomena that have been seen as the product of very recent developments, like the emergence of global memory or the writing of instant history, have many precedents and cannot automatically be explained with reference to very recent events.

The biggest difference between pre-modern and modern memory lies perhaps not in the area of public memory but in the practice of personal memory. Even then there are some interesting similarities. To have some recall of family and kin was, and has remained, of enormous importance. The role of women as keepers of family memory also seems to have been in place for a very long time. Yet early modern people were not inclined to think of their 'selves' as subject to change beyond the expected stages of growing and aging; their bodies changed, and people had different characteristics which matched the regulation of humours in the human body. They might change their minds through the acquisition of knowledge or spiritually through the experience of conversion. But they did not conceive of themselves as subject to individual change or use personal memories to build a narrative about their psychological development. This mindset also had consequences for the way early modern Europeans dealt with experiences of pain and suffering. Yet even there, the differences are far starker when comparing them with their modern European descendants than when we compare them with most non-Western people today. Moreover, even the most individually experienced modern personal memories are in fact heavily premediated by narrative schemes and cultural expectations. 
Early modern findings strengthen the case for modern psychologists and memory theorists to think about the variations as well as about the universals in the way humans today cope with memories of distress.

In general, it seems to us that there are two important gains to be had from a long-term perspective on the history of memory. First, a better knowledge of pre-modern memory practices can help modernists rethink some of their explanations for modern and postmodern memory practices and help further to 'provincialise (modern) Europe'. ${ }^{38}$ Even if hegemonic national memory was ever as hegemonic as some have claimed, its existence was never universal and has really been no more than a blip in the history of memory. Hybridity and diversity have always characterised memory and cannot be considered exclusive hallmarks of postmodernism. Secondly, we believe the essays in this volume suggest an alternative way to think about the history of memory, not as unchanging or linear, but as a cumulative and fluid process, in which new ways of engaging with the past constantly emerge and often end up in coexistence with older practices. Where these practices clash, conflict can result, but not necessarily so. The same individuals who invoke examples from the past one day will, after all, sing the praise of innovation the next, without experiencing this behaviour as inconsistent. It is important for us to acknowledge this reality if we are better to understand both modern and pre-modern memory, in Europe and beyond.

38 Dipesh Chakrabarty, Provincializing Europe. Postcolonial thought and historical difference (Princeton N.J.: Princeton University Press, 2000). 
Erika Kuijpers, Judith Pollmann, Johannes Müller, and Jasper van der Steen - 978-90-04-26125-9 Downloaded from Brill.com04/26/2023 11:57:20AM via free access 
PART ONE

MEMORY POLITICS AND MEMORY WARS 
Erika Kuijpers, Judith Pollmann, Johannes Müller, and Jasper van der Steen - 978-90-04-26125-9 Downloaded from Brill.com04/26/2023 11:57:20AM via free access 


\section{THE USABLE PAST IN THE LEMBERG ARMENIAN COMMUNITY'S STRUGGLE FOR EQUAL RIGHTS, 1578-1654*}

\section{Alexandr Osipian}

In any society, certain segments or layers of the distant past are considered to be pillars or origins of the social order. In early modern Europe, the past-and the distant past in particular-was seen not merely as a bygone reality but as the period of origin of important charters and privileges from which social groups or individuals derived status in the 'present'. Then as now, people who invoked the past relied on certain assumptions about causal chains that connected real or imagined factors in the past with observed or desirable outcomes in the present. These assumptions are not individual but derived from public discourse dominant in a given society-indeed they have to be in order to produce texts about, or images of, the past that are comprehensible for the public. This condition holds particularly true when such texts or images are used as arguments in litigation and court trials. In the case under discussion in this paper, the historical references had to be understandable to the king, his advisers at the royal court and to the representatives of the nobility in the Diet (sejm).

Yet there are more conditions to be met. The social-cultural anthropologist Arjun Appadurai argues that in order to be able to use the past in public debate there has to be consensus on four issues: (1) on what constitutes a source of authority, (2) on the existence of continuity between past and present, (3) on the value of the 'time depth' deployed in an appeal to the past, (4) and on the interdependence between one's own past and that of others. ${ }^{1}$ This set of norms is a useful analytical tool with which to approach a series of early modern legal disputes in Lemberg. Both the dominant city magistrates and the subaltern Armenian minority based their 'charters' and political claims on different representations of the past.

* This article was written thanks to my fellowships at the Jagiellonian University, Leipzig University, and the Deutsches Historisches Institut Warschau. I am grateful to the Foundation for the promotion of science in Poland, Kasa im. Józefa Mianowskiego, and to the Robert Bosch Stiftung for their financial support of these fellowships.

1 Arjun Appadurai, 'The past as a scarce resource', Man 16, no. 2 (1981), 203. 
Appadurai distinguishes between five norms that provide the cultural framework within which the charters of specific sub-groups are constructed, defended and mutually evaluated. These relate $(1)$ to the existence of textual evidence, that is (2) ratified by an external authoritative figure in the past, that (3) encodes (in addition to the claims of the group in question) the privileges of other relevant groups, and that is (4) continuous. Finally (5) the greater the antiquity of the referents of the charter in question, the better. Among these norms, the first is the least dispensable and the last, the most. ${ }^{2}$

Appadurai brilliantly demonstrates the multiplicity of different interpretations of the shared past by different interest groups, but in doing so, he accepts the past as a given body of shared knowledge/representations. In practice, the past can be invented and then successfully reinvented in the course of social conflict. This article will analyse how a group's past was constructed in the process of several court disputes which took place between the city magistrate and the Armenian community of Lemberg. It will investigate the reasons for the systematic revision of previous historical arguments made by Armenians, in order to highlight the deliberate reinvention of the past and the mechanisms of this reinvention. Secondly, it will demonstrate how the townspeople's framework of memory was influenced by the historical culture of the nobility. We will see that the evidence that has come to us is not the product of chance or reflective of a broad, continuous and largely anonymous stream of social memory. Quite the opposite.

$$
\text { * * * } \quad *
$$

Between $125^{\circ}$ and $135^{\circ}$ some Armenian merchants who were actively involved in the transcontinental trade settled in the principality in which the city of Lvov (modern-day Lviv in Ukraine) had recently been founded. ${ }^{3}$ From the very beginning, Lvov was a multiethnic city inhabited by Ruthenians, Armenians, Jews, Tatars and Saracens. German merchants and artisans, mostly from Poland and Silesia, had been invited by the Ruthenian prince Daniel (1238-64) in the mid-thirteenth century. After the Polish conquest of Galicia in 1349, the German townspeople (cives catholici)

2 Ibid., 204.

3 The original name of the city was Lvov or Lviv. Then it was renamed by German settlers in the mid-fourteenth century as Lemburg. In neo-Latin writings the city was named Leopolis. In Polish it is known as Lwów. From 1772 to 1918 the city-as well Galicia/Galizien province-was part of the Habsburg Empire where it was known as Lemberg. It is under this name that the city is known in modern times in the main European languages. 
became the dominant community as these Catholics were supported by the Polish kings. The rights of other urban 'nations' were guaranteed and confirmed by the Polish King Casimir III in 1356, when the city was granted the German Law (ius theutonicum) — the so-called Magdeburger Recht. Thus, Lvov was transformed into Lemberg.

Non-Catholics (schismatici) were not treated as cives, i.e. citizens of Lemberg. All members of the city magistrate were Catholics. ${ }^{4}$ Within the city walls, there were special streets for Armenians, Ruthenians, and Jews. The economic opportunities of the heretics and Jews were also restricted as they were not admitted into the artisan guilds. The trade in many goods was reserved to Catholics. ${ }^{5}$ The only economic niche which the Catholic city authorities allowed Armenians to fill was trade with the Orient. ${ }^{6}$ Armenian merchants served as interpreters in the royal chancery. Some of them were royal diplomats or spies. ${ }^{7}$ They also provided credit to the king in cases of emergency. For all these reasons, the Polish kings protected the Armenian community.

The city magistrate made successive efforts to restrict the judicial autonomy of the Armenian community. In accordance with the royal decree of 1469, the office of Armenian judge (advocatus, wójt) was abolished. Decrees of 1476 and 1510 established a new order that placed the city judge at the head of the court of Armenian elders. ${ }^{8}$ Cases of manslaughter, certain injuries, larceny and Armenian real estate (the 'four articles') fell under the jurisdiction of the city, which would try these cases according to the Magdeburg Law. Other court cases, both civil and criminal, came under the jurisdiction of the mixed court and were judged by Armenian Law. ${ }^{9}$

4 Eleonora Nadel-Golobic, 'Armenians and Jews in medieval Lvov. The role in oriental trade, 1400-16oo', Cahires du Monde russe et soviètique 20 (1979), 352-353.

5 Łucia Charewiczowa, Ograniczenia gospodarcze nacyj schyzmatyckich i żydów we Lwowie $X V-X V I w$. (Lwów: Towarzystwo Historyczne, 1925).

6 See: A. Dziubiński, Na szlakach Orientu. Handel między Polska a imperium Osmańskim w XVI-XVII wieku (Wrocław: Fundacja Na Rzecz Nauki Polskiej, 1998); Nadel-Golobic, 'Armenians', 363-365.

7 B. Baranowski, 'Ormianie w slużbe dyplomatycznej Rzeczypospolitej', Myśl karaimska. Rocznik naukowo-spoteczny. Seria Nowa 1, (1945-1946), vol. 23, 119-137; K. Wróbel-Lipowa, 'Dzialalność dyplomatyczna Ormian polskich w XVI-XVII w.', in M. Zakrzewskiej-Dubasowej (ed.) Studia z dziejów kontaktów polsko-ormiańskich, (Lublin: Studia z dziejów kontaktów polsko-ormiańskich, 1983), 107-117.

8 Pryvilei natsionalnyh hromad mista Lvova (XIV-XVIII st.) [Royal charters granted to the national communities in the city of Lviv in the fourteenth to eighteenth centuries], ed. Myron Kapral (Lwów: Piramida, 2000), 146-148, 169-172.

9 F. Bischoff, Das alte Recht der Armenier in Lemberg (Vienna: Gerold in Komm., 1862), $39-42$. 
In the second half of the sixteenth century tensions grew between the Armenian community and the Catholic patricians. Using capital accumulated in trade with the Orient, Armenian merchants began to push their Catholic competitors out of the Lemberg market. Armenians, who constituted only 19 per cent of the city's population, owned 62.5 per cent of so-called 'rich shops' and 78 per cent of so-called 'poor shops'. Armenian merchants bought houses beyond the designated Armenian street. In 1578 , they owned 19 per cent of houses in the intramural part of the city, a percentage which had grown to 24 per cent by $1600 .{ }^{10}$ Their efforts to buy houses in the prestigious central market square were seen by the Catholic patricians as a challenge to Catholic dominance in the city. On their part, prosperous Armenian merchants wanted to obtain civil and economic rights equal to those of the Catholics. In 1563 , the Armenian community filed a legal case in which they complained to King Sigismund II August $(1548-72)$ that the city magistrate unlawfully restricted their judicial and economic rights. In response, the king issued an edict which for the most part maintained the status quo. ${ }^{11}$

In 1578, the Armenians tried again, this time in the presence of the recently elected King Stefan Batory (1576-86). In response, the magistrate stated that 'Armenians are not equal [to them] because of the differences in language and religion'. That is, they were not citizens (cives) of Lemberg but strangers and infidels. Yet the Armenians argued that they were citizens of Lemberg; their ancestors had not been restricted in their rights. And to make their case, this time they also invoked a charter, which stated that their ancestors had been invited by the Galician prince Daniel. ${ }^{12}$ The king was duly impressed and now granted to the local Armenians economic rights equal to those of the Catholics. ${ }^{13}$

In the numerous previous legal conflicts between the magistrate and the Armenian community, the Armenians had never before used the charter of Prince Daniel to prove that their ancestors had settled there at the

10 F. Sribnyi, 'Studii nad organizatsieiu l'vivs'koi Stavropigii vid kintsya XVI do polovyny XVII st.: Material'ni vidnosyny bratchykiv' [Studies devoted to the organization of the Lviv Stavropigial Orthodox Brotherhood from the late sixteenth to the mid-seventeenth centuries: the economic relations of the brothers], Zapysky Naukovoho tovarystva imeni T.G. Shevchenka [Proceedings of the scientific society named after Taras Shevchenko] 111 (1912), 9.

11 Pryvilei natsionalnyh hromad, 277-283.

12 Quoted by Myron Kapral, Natsionalni hromady Lvova XVI-XVIII st. Sotsialno-pravovi vzaemyny [The national communities of the city of Lviv in the sixteenth to eighteenth centuries: social and juridical relations] (Lwów: Piramida, 2003), 368-369.

13 Pryvilei natsionalnyh hromad, 298-300. 
moment of the city's foundation by Lev, son of Daniel. Previously, they had shown to the king only the royal decrees that had been issued to the Armenian community by his predecessors. And that action is understandable. Daniel's charter was of no significance because after the Polish conquest of Galicia in 1349 and the re-foundation of Lvov as Lemberg in 1356, the charters issued by Ruthenian princes lost their judicial power. The land grants issued by the Ruthenian princes to the local nobility were translated into Latin and confirmed by the Polish kings in the second half of the fourteenth century. By then, the Ruthenian originals had gone out of use. In 1578, however, the remote past, the epoch before the Polish conquest which had been previously neglected, furnished a crucial argument in the dispute. Why did Armenians use Daniel's charter in 1578 while they refrained from doing so in 1563 ?

The answer lies in the 1569 Unification of the Kingdom of Poland and the Grand Duchy of Lithuania. Every new king - after the extinction of Jagiellonian dynasty in 1572 kings were elected by the assembly of noblesconfirmed to the Armenian community of Lemberg the decrees issued by his predecessors, thereby reaffirming existing agreements between the ruler and a group of subjects. ${ }^{14}$ The extinction of the Jagiellonian dynasty (1386-1572) and four years of interregnum and calamities in 1572-76 were perceived by contemporaries as a break with the past, but this break also created an opportunity to revise some 'charters' derived from the preJagiellonian epoch. ${ }^{15}$ In 1569 , the Unification of Poland and Lithuania was proclaimed in the Diet in Lublin. Both states maintained their autonomy in the new dual state, but the lands of South Ruthenia/Rus' (modern day Ukraine) passed from the Grand Duchy of Lithuania to the Kingdom of Poland. These South-Ruthenian lands with their numerous Orthodox nobility, now joined Galician Rus' Ruthenia Rubra conquered by Poland in the 1340s. Whereas, previously, the Ruthenian past had little political value in the Polish kingdom, the situation was now changed. The Grand Duchy of Lithuania prided itself on its cultural heritage of Kievan Rus', and an overwhelming majority of the Duchy's nobility and aristocracy were Orthodox Ruthenians. Since the Act of Unification resulted from a

14 Ibid., 124, 136-137, 167-168, 251-252, 266-267, 295-296, 302.

15 Many contemporary Polish authors trace Polish history by taking the death of King Sigismund II August in $\mathbf{1 5 7 2}$ as the starting point of their narratives. See for instance: Ś. Orzelski, Bezkrólewia Ksiag Ośmioro 1572-1576 (Kraków, 1617); Reinhold Heidenstein, Rerum Polonicarum ab excessu Sigismundi Augusti libri XII (Frankfurt, 1672); I.D. Solicovius, Commentarius brevis rerum Polonicarum a morte Sigismundi Augusti (Danzig, 1647). 
compromise achieved by the nobility of both countries, the rights and privileges of the South-Ruthenian nobility were confirmed in the Kingdom. Thus, the Act of Unification of 1569 in a sense rehabilitated the Ruthenian past in the Kingdom of Poland. ${ }^{16}$

The Diet of Lublin also confirmed charters issued by Prince Lev/Leon, son of Daniel. Daniel's son Lev was popular in Lemberg since local legends regarded him as the city's founder. ${ }^{17}$ Many of these charters were fabricated long after the prince's death. However, they were not forged ex nihilo. In many instances, the original charters had been lost through wars, fires, and other societal and natural disasters. The fabricators themselves - mostly local noblemen — saw the fabrication as a renovation and restoration of the lost charters in accordance with memory and tradition. They also introduced new contemporary realities into the renovated charters in accordance with their claims (mostly for the inherited lands granted to their forefathers by Ruthenian princes of Galicia). ${ }^{18}$ In the 1578 legal dispute, the Armenians of Lemberg would follow this practice.

'The old and short charter' of Prince Daniel, which they showed to King Stefan Batory in 1578 and to the Catholic Archbishop of Lemberg JanDymitr Solikowski in 1597, could be interpreted as a letter of protection given by the Prince to Armenian merchants. Such letters granted free passage-salvum conductum - to the merchants and guaranteed their protection in the domains of a certain lord or state. By adding new details, Armenians could transform this letter of free passage into a charter of invitation by which Daniel invited their ancestors to settle in his domains (locatio).

In a complaint to King Sigismund III, submitted by Catholic townspeople of Lemberg between 1597 and 1600 asking him to revise the royal decree of 1578 , the complainants stated that '... Armenians connect their invitation with the aforementioned Daniel. At that time, the city of Lviv

16 The rehabilitation of the Ruthenian past from the point of view of Polish upper classes was also reflected in the growing interest in the history of the Ruthenian lands. Two works on this subject were published around 1580: Alexander Guagninus, Sarmatiae Europeae descriptio (Kraków, 1578); Maciej Stryjkowski, Kronika polska, litewska, żmódzka i wszystkiéj Rusi [Chronicle of Poland, Lithuania, Zhemaitia and of all Rus'] (Kraków, 1582).

17 The legends were recorded by Martin Gruneweg - a German, born in Danzig, who was in the service of Armenian merchant Aswadur in 1582-1588: Martin Gruneweg, 'Opys L'vova' [Description of Lemberg], Zhovten 10 (1980), 110-111.

18 V.F. Inkin, 'ChyeistorychnaosnovavfalsyfikatakhhramotkniaziaL'vaDanilovicha?' [Is there historical ground in the falsified charters of the Prince Lev, son of Daniel?], Visnyk L'vivs'koho universytetu [Bulletin of the University of Lviv. Historical Issue] 24 (1988), 61-62. 
did not exist yet. In accordance with it, there is no doubt whatsoever that they were invited not to the city of Lviv, but to the lands of Rus' ...' ${ }^{19}$

Although the Act of Unification of 1569 had guaranteed equal rights only to the noble estate, this act was also invoked as a precedent by the Orthodox townspeople of Lemberg. The Ruthenian community appealed to King Sigismund II August who in turn issued a decree on 20 May 1572, by which he granted Orthodox Ruthenians of Lemberg the same rights as the Catholic townspeople, in particular the right to have their representatives in the city council. In the text of the decree the king referred to the recent Act of Unification. The decree of 1572 emphasised that the Ruthenians in Lemberg were to enjoy the same rights as the 'Polish townspeople of the Roman faith', which 'were granted to the city of Lemberg on different occasions and in different ways by our glorious predecessors, dearest kings of Poland, and dukes of Rus', as well as by other lords and governors of our kingdom and domains' ${ }^{20}$ For the first time in a royal decree issued to the city of Lemberg, there was mention of privileges granted by the Ruthenian princes. Moreover, these princes (duci Russiae) were put in a line after the Polish kings but before 'other lords and governors'. Thus, the Ruthenian past that predated the Polish conquest of the 1340 secame valuable and could also be used by the Armenians.

Another precedent was probably also important for Armenians in 1578 . In the trial, the magistrates demanded that the Armenians show them a charter of foundation of their community in Lemberg. Initially the Armenians said that there was no such a charter at their disposal, but later they 'showed the old and short charter of [the prince] Daniel'. In accordance with late medieval and early modern legal practices, every foreign 'nation' invited or allowed to settle in a certain city within the Kingdom of Poland was granted a charter of foundation by a Polish king. The Jews were the most evident example. ${ }^{21}$ Evidently, Armenians also needed such a charter of foundation. The problem was that Armenians had settled in Lemberg before the Polish conquest, when Galician Rus' was ruled by Ruthenian princes. Ruthenian charters - written with Cyrillic characters-were of

19 Quoted by Yaroslav Dashkevich, 'Drevniaya Rus i Armenia v obshchestvennopoliticheskih sviaziah XI-XIII vekov. (Istochnikiissledovaniatemy)' [Social and political contacts of ancient Rus and Armenia in the eleventh to the thirteenth centuries: problems of new reading of source material], Drevneyshie gosudarstva na territorii SSSR. Materialy $i$ issledovania $(1982 \mathrm{~g}$.) [The ancient states on the area of the USSR. Sources and studies (1982)] (Moscow: Nauka, 1984), 195.

20 Pryvilei natsionalnyh hromad, 46.

21 Ibid., 390, 426. 
no value if not confirmed by Polish kings. Galician Rus' and Lemberg were seen by the city patricians as having come to the Polish kingdom by the law of war (jure belli) - thereby the city was founded in 1356. Only the rehabilitation of the pre-Polish, that is a 'Ruthenian' past, and the precedent of the Ruthenians in 1572, stimulated the Armenians in 1578 to present Daniel's letter as their charter of foundation.

We see that Appadurai's definition of depth works quite well in the case of the trial of 1578. Armenians tried to derive their rights from a period situated more 'deeply' than the royal decree of 1356 , which dominated the discourse of the Catholic patriciate. Nevertheless, it is evident that 'the relative value of different time-depths' was not constant in this complex society. It changed in the course of the efforts made to establish social cohesion after the Unification of Poland and Lithuania.

Appadurai's notion of a 'cultural framework within which the charters of specific sub-groups are constructed, defended and mutually evaluated' embraces the superiority of textual evidence, a credible external authoritative figure in the past, and the greater antiquity of the referents of the charter in question. At the same time, Appadurai's assumptions that the charter should be based on an authoritative document that encodes the privileges of a maximum number of other relevant groups and that the evidence for the charter in question should be reflected, as far as possible, continuously in the documented past, does not work in the Lemberg case. Daniel's letter-even when enriched with new meanings by Armenians in 1578-did not encode the privileges of any other relevant group. Every urban 'nation' derived its rights or claims from different segments of the past. What was a valuable past for one group could well be worthless for another. Moreover, Daniel's letter and 'charter' were never reflected continuously in the documented past before 1578 .

There is no doubt that in the 1570 , the 'Ruthenian past' was included into 'a minimal set of formal constraints' because of the 'cultural consensus'22 — as well as a political one - achieved by representatives of the noble estates of Poland and Lithuania in the Diet of Lublin in 1569. Thus, the claims of Armenians in 1578 could be based on the ratification of a credible external authoritative figure in the past-the letter of the Ruthenian prince Daniel. Daniel's letter was in particular valuable for Armenians since it situated their invitation-real or imagined-deeper in the past than the re-foundation of Lemberg on the basis of the Magdeburg

22 Appadurai, 'The past as a scarce resource', 203. 
Law in 1356. The Diet of Lublin in 1569 and the rupture of the 1570 s established a new cultural consensus as to the authority, continuity, and depth of the Ruthenian past in general, and thereby of Prince Daniel's charter in particular, within the Polish upper-classes.

But the interdependency of Daniel's past with the Polish past also had negative consequences for the Armenian case. In 1597, the Catholics submitted a complaint to King Sigismund III (1587-1632). While they conceded that the Armenians' ancestors had indeed been invited into Lemberg, they accused Armenian warriors of participating in the hostile incursions against Poland led by Prince Daniel or his son Lev/Leon together with the Tatars in the 1250s-1280s:

Lviv was founded around 128 o by Leon, son of the Ruthenian prince Daniel. This Daniel died around 1263 or 1264. It means that the Armenians had been invited earlier, since Armenians connect their invitation with the aforementioned Daniel. At that time, the city of Lviv did not yet exist. In accordance with it, there is no doubt whatsoever that they were invited not to the city of Lviv, but to the lands of Rus' in order to wage war together with Daniel, Ruthenians and Tatars against the Kingdom [of Poland] as it is written in the chronicles of the Kingdom at the times of [Prince] Lesco Czarny. Equally, even if the Armenians later lived in accordance with the privileges [granted to them by] Leon-which we never admit [as legitimate]-they lost all these privileges in accordance with the law of war exactly when, conquered with a sword, part of Rus' with the city of Lviv, was subjugated by [King] Kazimierz in 1340. It means that the foundation of Lemberg should be connected with his [Kazimierz's] ordinance but not of those previous princes of Rus'. It goes in accordance with the first privilege of Kazimierz granted in Sandomierz in $1356 .^{23}$

In this way the Armenians-loyal subjects in 1578-were turned into the descendants of Poland's enemies. In April 1600, the royal court in Warsaw considered the complaint of the Lemberg magistrate. The new edition of the decree proclaimed equal rights for Armenians in general but limited their opportunities in many particular cases.

To construct this historical accusation against the ancestors of Armenians, Lemberg's Catholic patricians used certain sentences about Princes Daniel and Lev and about the foundation of Lvov that were mentioned in a history of Poland written by Martin Kromer (1512-89). The patricians also invoked isolated sentences from other texts as well as the fact

23 Quoted by Dashkevich, 'Drevniaya Rus i Armenia', 195. 
that the Armenians living in Lemberg used Tatar as the language of their everyday conversation. ${ }^{24}$

Kromer's history was very popular. It was published in Latin in 1555 , $155^{8}, 1568$, and 1589, in German in 1562, and in Polish in 1611. Kromer had been born into a burgher family of German immigrants in Biecz, in southern Poland, which rendered his work particularly authoritative as a source of historical knowledge for Polish townspeople. ${ }^{25}$ In $155^{2}$, he was ennobled and granted a coat of arms for his diplomatic services to Kings Sigismund I and Sigismund II, and in 1573 he was promoted to Prince-Bishop of Warmia (Ermland). ${ }^{26}$ Thus, his career and royalist vision of Polish history also made his work authoritative at the royal court. Along with the emergence of printed books and the spread of interest in national history among the Polish nobility and urban upper class, Kromer's work offered an extensive historical framework for the public past.

In the Polish historical tradition, Prince Daniel and his son Lev were seen as enemies. Kromer's history mentioned Lemberg for the first time in 1280 , in connection with the war between the Ruthenian Prince Lev and the Polish Prince Leszko Czarny (Lesco Niger). ${ }^{27}$ He tells how Prince Daniel had defeated other Ruthenian princes and made them his vassals, establishing a near-monarchy in Southern Rus'. In 1254, he was crowned by the papal legate, Cardinal Oppiso, with a crown sent by the pope, on condition of entering into unification with the Roman Catholic Church and undertaking joint military actions against the Tatars. However, Daniel ignored his promises and, together with the Tatars and pagan Lithuanians, devastated Christian countries. ${ }^{28}$

The sixteenth and seventeenth centuries witnessed growing discrimination against townspeople by the nobility (szlachta), which ruled the country through their dominance in the Polish Diet-'Sejm'. The arrogant attitude toward townspeople and peasantry was affirmed and elaborated within the so-called culture of Sarmatism or Sarmatian ideology. ${ }^{29}$

\footnotetext{
${ }^{24}$ See Alexandr Osipian, "The lasting echo of the Battle of Grunwald. The uses of the past in the trials between the Armenian community of Lemberg and the Catholic patricians in 1578-1631', Russian History 38, no. 2 (2011), 243-280.

${ }^{25}$ Ludwik Finkel, Marcin Kromer. Historyk polski XVI wieku. Rozbiór krytyczny (Kraków: W Drukarni Uniwersytetu Jagiellońskiego, 1883), 7.

26 Ibid., 34, 36.

27 Martinus Cromerus, De origine et rebvs gestis Polonorum libri XXX (Cologne, 1589), 171.

28 Ibid., 161.

29 Stanisław Cynarski, 'The shape of Sarmatian ideology in Poland', Acta Poloniae Historica 19 (1968), $5^{-17}$.
} 
Noblemen proclaimed themselves to be the descendants of the Sarmatian warriors, who dominated Eastern Europe in ancient times. Townspeople and peasantry became descendants of the subjugated Slavs. Noble status was very attractive to city patricians not only as a sign of prestige but also because it freed them from many taxes.

It is hardly surprising that both parties to the conflict in Lemberg, Armenians and Catholics, had also begun to emphasise the noble origins of their ancestors. Under the influence of Sarmatism, in the writings of the local Catholic humanists the early German settlers in Lemberg were transformed into German mercenaries (stipendiarii Germani) in the service of King Casimir III, who conquered Galicia and settled his German warriors in Lemberg in the 1340 s. $^{30}$ These self-imagined glorious warrior ancestors reflected the ambition of the contemporary Lemberg patricians to obtain noble status. Yet the efforts of wealthy Armenian merchants in Lemberg to claim their own warrior ancestors were now turned against them: in the Catholic complaint of 1597 the Armenians were proclaimed enemies of Poland.

Nevertheless, Catholics in Lemberg generally accepted that the early Armenians who settled in the city were warriors in the prince's service. For instance, Jan Andzrej Próchnicki, Lemberg's Catholic archbishop in 1614-33, stated in a 1622 report addressed to the Congregatio de Propaganda Fide: 'It is said that [Armenians] migrated from Armenia to these lands three hundred years ago, invited by the Ruthenian prince Leon for the military service. Then they degenerated into merchants and spies'. ${ }^{31}$ The Papal Nuncio in Poland Honoratio Visconti (1630-36) in 1631 also described the origins of the Armenian migration to Rus'. Apparently, the report was written by Visconti from the evidence presented by Armenians, and the story recorded in Visconti's account reflects all the previous historical debates between Armenians and the Catholic patricians. 'Thus, Armenians have lived for about 500 years in the provinces of Rus'.

30 Sebastian Petrici, Polityki Aristotelesowey, to iest rządu Rzeczypospolitey z dokładem ksiag osmioro [Eight books of Aristotle's 'Politics', that is on the government of a republic, with comments] (Kraków, 1605), 187; Ioannes Alnpekius, 'Topographia civitatis Leopolitanae', in Stanisław Rachwał (ed.) Jan Alnpek i jego “Opis miasta Lwowa” z poczatku XVII w [Jan Alnpek and his 'Description of the City of Lviv' written in the early seventeenth century] (Lwów: Wschód, 1930), 11; J.-B. Zimorowicz, 'Leopolis triplex', in J.-B. Zimorowicz, Opera quibus res gestae urbis Leopolis illustrantur, ed. K.J. Heck (Lwów: s.n., 1899), 37, 61-3.

31 Litterae Episcoporum historiam Ucrainae illustrantes (1600-19oo) (Rome: PP. Basiliani, 1972), vol. 1, 87 . 
Their arrival, initially discussed and agreed upon by these dukes with the Nation, was finally concluded in the times of Prince Daniel and affirmed by his successor Leon, at that time ruler of Rus', who founded the city of Leopolis [at that time capital of Rus'] ${ }^{32}$

After they lost their case in 1600 , one might logically have expected the Armenians to abandon their link with Daniel and Lev as 'inviting-fathers'. Yet, this did not happen. Instead, until the early 1630s, Armenians continued to maintain this version of their ancestors' invitation to Rus' and city of Lviv by Daniel and/or Lev. It was only the beginning of a new phase of open conflict between the two rivalling groups in the 1630 s which stimulated Armenians to revise their version of the usable past and introduce substantial changes to it.

The 1620 s and ' 30 s witnessed a gradual change in the Armenian narrative of invitation. This new perception of the past was influenced by two factors-education and reading. Slowly, Armenians were transformed from an isolated community of merchants into consumers of Polish Renaissance culture. Many young Armenians received a Renaissance education in the Academy of Zamość, which had been founded in 1585 . The Polish translation of Kromer's history was published in 1611, thus becoming accessible to Armenian readers. This new, well-educated generation of Armenians in Lemberg realised that neither Daniel nor Lev-discredited within the framework of Kromer's history-could be a credible external authoritative figure from the past. The religious conflict of the 1630 stimulated a search for a new 'founding-father' of the Armenian diaspora in Ruthenian lands.

In 1630, Nigol Torosowicz, Armenian bishop of Lemberg, with support of Catholic Archbishop Andrzej Próchnicki and with the implicit consent of King Sigismund III (1587-1632), tried to force a unification of the local Armenians with the Roman church. The archbishop was actively supported by the Jesuits, the royal governor (capitaneus), and city authorities. The Armenians for the most part rejected religious unification. This religious conflict resulted in a series of trials and sometimes in violent acts against Armenians and their property. ${ }^{33}$ Under such circumstances

32 Acta nuntiaturae Polonae, ed. Adalbertus Biliński (Rome: Institutum Historicum Polonicum Romae, 1992), vol. 24, part 1, 278.

33 For a detailed description see: Edmond Schütz, 'An Armeno-Kipchak document of 1640 from Lvov and its background in Armenia and in the diaspora', in György Kara (ed.), 
Armenians constructed a new version of their past, which could be more useful in protecting their rights.

A delegation of Armenian elders (seniores) submitted a confession of faith (confessio fidei) to King Wladisław IV in 1641, in which they declared allegiance both to St Peter and St Gregory, and accepted the decisions of the first seven Councils of the Church. The Polish kings considered these confessions to be so significant for the process leading to the catholicisation of the Armenians that they confirmed all their former privileges. As a result, Wladisław IV renewed the rights they submitted to him in $1641 .^{34}$

Along with the royal decrees by which Polish kings granted rights to their Armenian subjects in the fifteenth and sixteenth centuries, the Armenians now also presented a short charter allegedly issued by a Ruthenian prince, who was neither Daniel nor Lev. It was a letter from Prince Feodor/Theodore, son of Dmitry. His title and domains were not indicated any more precisely and the date was also absent. 'From prince Teodor, son of Dmitry, to the Armenians of Kosochac(ean): Come under my hand and I shall grant you freedom for three years'. ${ }^{35}$ Thus, in 1641 Armenians officially put into circulation the so-called 'charter issued in 1062 by the Ruthenian prince Feodor, the son of Dmitry'. But in 1062 there were no Ruthenian princes with such a name. Actually, the Armenians used the letter issued - perhaps in $1382^{36}$ — by the Volhynian prince (in 1377-93) Feodor, the son of Lubart (the Lithuanian prince Lubart was baptised as Dmitry) to invite the Armenian merchants into his principality. It was a typical protection charter (salvum conductum) for foreign merchants, of the variety we have seen above. Why had the Armenians of Lemberg never used Feodor's letter before 1641? In the early seventeenth century, the old Armenian communities in Volodymyr and Lutsk-both in the province of Volhynia-as well as in Kiev were in the final stage of their

Between the Danube and the Caucasus (Budapest: Akadémiai Kiadó, 1987), 247-330; esp. 285-313.

34 Ibid., 309-310.

35 This Ruthenian document was lost in the mid-nineteenth century. The original content of Feodor's letter is known to us thanks to F.-X. Zachariasiewicz (1770-1845): 'Oto Kniazia Teodora Dmytrowicza Kosochackim Armenom. Prejdili na moju ruku dam wam wolnost na try lita' in F.-X. Zachariasiewicz (ed.), Wiadomość o Ormianach w Polszcze (Lwów: Józefa Schnaydera, 1842), 10.

${ }^{36}$ F.-X. Zachariasiewicz stated that he could not decipher the last words of Feodor's letter. This is probably because he tried to read them as a word rather than as a date. In medieval Ruthenian manuscripts figures were transmitted in Cyrillic script. This document would also have used medieval Orthodox chronology rather than that of the Christian era. 
decline. The few Armenians still living in these cities were not able to pay their priests and to maintain their churches. In the 1620 s, the prosperous Armenian community of Lemberg took the Armenian churches and priests in these cities under protection. ${ }^{37}$ It is possible that Armenians of Lemberg took possession of the archives from these churches and among other papers found Feodor's letter.

Yet in the process of translating the original letter from Ruthenian into Latin in the royal chancellery on 18 October 1641, the Armenians included in the Latin copy information they could use in their legal conflict with the Catholic patricians. According to the extended and updated charter, the prince invited Armenian warriors to help him in war and permitted them to settle anywhere in his domains: "The charter issued by Feodor, (son of) Dmitry, prince of Rus', translated from Ruthenian into Latin, and granted to Armenians in the year $1062 \mathrm{AD}$, now read as follows: ${ }^{38}$

Theodor great prince of Rus', son of Demetr, to the Armenians of Kosohac(ean). Who wish to come here, they should come to help me, and I am going to grant them freedom for three years. And when you shall be with me, you may freely go wherever it pleases you. ${ }^{39}$

Since in the Ruthenian original the title of the prince was not indicated, in the Latin translation he was easily transformed into 'the great prince of Rus'. Along with the other documents submitted by Armenians in 1641 the extended Latin copy of Feodor's charter was written down in the records of Matricularium Regni Poloniae. The Armenians received from the royal chancellery the Latin copy, which they used as an officially confirmed, credible document in future trials. ${ }^{40}$

In 1654 Armenians won the trial and were granted equal rights with the Catholics according to the decision of King Jan Casimir/Kazimierz

37 Lekhatsi, Putevye zametki, 249; Akty otnosiashchiesya k istorii Yuzhnoy i Zapadnoy Rossii, sobrannye i izdannye arkheograficheskoy komissiey [Acts concerned with the history of southern and western Russia, collected and published by the Archeographic Commission] (St Petersburg, 1865), vol. 2, 73-74.

38 I use italics to accentuate new words inserted into the Latin translation in 1641.

39 In Latin it reads: 'privilegium Theodori Demetrii Ducis Russiae ex Ruthenico idiomate in latinum transpositum in a. Dni millesimo sexagesimo secundo Armenis datum, cujus ea sunt verba: Ecce Magni Ducis Theodori Demetrii filii Kosohacensibus Armenis, qui huc volunt venire, veniant in auxilium meum, et ego vobis dabo libertatem ad tres annos et cum fueritis apud me, ubi quis voluerit, illuc ibit libere'. Quotedfrom: F. Bischoff, Urkunden zur Geschichte der Armenier in Lemberg (Vienna: K.K. Hof- und Staatsdruckerei, 1864), 4; Sadok Barącz, Rys dziejów ormiańskich (Tarnopol: Józefa Pawlowskiego, 1869), 6o-61.

40 Schütz, 'An Armeno-Kipchak Document', 308-309. 
(1648-68). There is a mention in the royal decree that Armenians demonstrated to the King 'a charter issued by the Prince Dmitry in 1062'. ${ }^{41}$

With the end of the 'hot' phase of the conflict in the late 1650 s and when facing the common threat of the Cossack-Tatar and Cossack-Muscovite sieges of Lemberg in 1648 and 1655 , respectively, and the probable dissolution of the Polish-Lithuanian Commonwealth in $1655^{-58}$, the magistrates of Lemberg and the Armenian community found their way to a shared vision of the early period of urban history. The second half of the seventeenth century witnessed the process of coming to terms with the instrumentalised past, which was accompanied by the ennoblement of the upper strata of both rivalling groups. In 1670, a French envoy visited Lemberg. His secretary Ulrich von Werdum described the multinational population of the city and noted in his diary that "These Armenians, according to their own words, 600 years ago were invited into Poland from the Pontic Island of Caffa, which earlier was known as Theodosia, by the Ruthenian prince Dmitry for [military] assistance against his rebellious subjects. For the loyal service [the prince] granted them many significant privileges'. ${ }^{42}$ Jan Thomas Józefowicz (1662-1728) —a Catholic canon born into an Armenian family-wrote a history of the Lemberg archdiocese in $1700-14 .{ }^{43}$ According to Józefowicz, "[The Armenians] were invited by the princes of Rus' against the Tatars, who many times made incursions into Roxolanian/Ruthenian lands, and the Nosochacean Armenians were granted a privilege by the great prince Theodor, son of Dmitry, written in the Ruthenian language and translated into Latin in the year 1062 of the Nativity of our Saviour, with exemption from taxes for three years'. Thus, having been accused in 1597 of being allies of the Tatars, in the early eighteenth century the imagined ancestors of Lemberg Armenians were finally transformed into brave defenders of Ruthenian lands against Tatar incursions. Józefowicz's narrative can be seen as a compromise between the two competing versions of the past. By the late seventeenth century, the newly invented invitation of the Armenians by Prince Feodor, son of Dmitry, in 1062, had become part of the memory canon of local Armenians,

41 Pryvilei natsionalnyh hromad, 334.

42 Ulrichvon Werdum, 'Shchodennykpodorozhi, yakuyazdiysnyvuroky 1670, 1671, 1672... cherezkorolivstvo Polske' [Itinerary of my voyage in 1670, 1671, 1672 through the Kingdom of Poland], Zhovten 9 (1983), 91.

43 Jan Thomas Józefowicz, 'Leopoliensis ArchiEpiscopatus Historia Ab anno 1614...', Collecta 672, Microfilm 11417, Biblioteka xx Czartoryskich (Library of the Czartoryski family, Krakow, Poland). Józefowicz's narrative was actually a continuation of an earlier one written by Tomasz Pirawski (1565-1625): Relatio status almae archidiocesis Leopoliensis. 
legitimised by inclusion into the urban history narrative and later seen by Romanticist historians as a part of tradition passed within the community from generation to generation since time immemorial.

\section{Conclusion}

As we have seen, each of the successive stages of the creation of a memory was closely linked with the centres of power. Because of this relationship, the authors were required to take a qualified public (however limited) into account. Kromer's work deeply influenced the normative framework for debating the past in the urban community of Lemberg as well as beyond it - at the royal court and Diet, where the arguments of both sides were considered and evaluated, and solutions found. Kromer's history of Poland introduced into public discourse a certain coherent cluster of images of the past. It structured townspeople's historical imagination and became its framework for at least the next century. All the new representations of the past had to be situated either inside this framework with reference to Kromer's narrative or outside it. The latter option was used by Armenians in 1641 when they introduced a new person-Prince Feodor, son of Dmitry - into their narrative of their ancestors' invitation to Rus'. The prince was absent from Kromer's history. Moreover, an earlier date was introduced in the Latin translation of the charter-1062. This date was temporarily situated outside Kromer's historical framework-long before the Polish conquest of Galician Rus' in the 1340s and the invasion of Tatars/ Mongols and their incursions with Ruthenian princes into Poland in the thirteenth century. In 1062, Rus' was independent and almost completely absent from Kromer's history. By changing the 'inviting father' to Prince Feodor, son of Dmitry, in place of the 'discredited' Princes Daniel or Levand the date of the invitation - 1062 instead of the 1260s-70s-Armenians preserved and even reinforced the main idea of their narrative- their ancestors were warriors invited to Rus' by the Ruthenian prince who freed them from taxes and duties except for military service. Thus, Armenians could use the updated narrative to stress that 1 ) they were not 'newcomers' because their ancestors had been invited in 1062-even before the Germans and Poles had settled in Galicia; 2) they should not be treated as tolerated aliens but as true citizens of Lemberg and be free of improper taxes and fees; and 3) their elite could appeal to the king for ennoblement because their ancestors had been noble and brave warriors who had been rewarded with privileges. 
If Arjun Appadurai emphasised the constraints of using the past, this article has, first, tried to demonstrate how social actors could avoid these constraints. Appadurai underlines that the 'interdependence of charters can occur in one of two ways. Either a specific authoritative text in the past encodes the rights of a larger number of groups.... Or it can occur when a group links its claim in a general way with a broad textual tradition or corpus, to which other groups must also necessarily have recourse'. ${ }^{44}$ In the case of the Armenians in Lemberg, it is evident that in 1578 and in 1641-54 they preferred to use unique sources in order to avoid both the royal decree of 1356 , which 'encoded the rights of a larger number of groups', and Kromer's history of Poland, which had become 'a broad textual tradition' in the late sixteenth and early seventeenth centuries.

While Appadurai accepts the suggestion that the normative framework for debating the past is culturally variable, we can now conclude that it is also variable in a given culture in the process of inter-group interaction. This means that interaction between competing interest groups stimulates permanent construction and reconstruction of the valuable segments of the past that could be usable in present social conflicts. The normative framework for debating the past, so well described by Appadurai, poses not only constraints but also creates opportunities.

44 Appadurai, 'The past as a scarce resource', 211. 
Erika Kuijpers, Judith Pollmann, Johannes Müller, and Jasper van der Steen - 978-90-04-26125-9 Downloaded from Brill.com04/26/2023 11:57:20AM via free access 


\title{
A CONTESTED PAST. MEMORY WARS DURING THE TWELVE YEARS TRUCE (1609-21)*
}

\author{
Jasper van der Steen
}

In 1609, Spain and the Dutch Republic signed a Twelve Years Truce after waging war for more than forty years. In the running up to and during the ceasefire, the highest military commander Prince Maurice as well as orthodox Calvinists actively opposed efforts to forge a lasting peace. This anti-peace lobby tried to convince government authorities, and the people of the Netherlands in general, that the Spanish had a track record of not keeping their word and that they could, therefore, not be trusted.

To substantiate their claim of Spanish unreliability, anti-peace propagandists reduced the history of the Revolt against the Habsburg overlord Philip II of Spain to a selection of gruesome episodes in order to remind people of the cruelties Spanish rulers and their soldiers were capable of. ${ }^{1}$ The result was a historical canon: a relatively inclusive and non-confessional story aimed at convincing as many people as possible that the war should be resumed. But the inclusive character of this narrative was put to the test when new internal divisions compromised the unity of the Republic. Around 1610, a religious quarrel broke out about the Reformed doctrine of double predestination between two professors of theology in Leiden: Jacobus Arminius and Franciscus Gomarus. The disagreement between the two men was ostensibly a matter for academics only, but in fact it almost dragged the state into civil war. ${ }^{2}$

* Research for this article was funded by an NWO VICI grant for the research project Tales of the Revolt. Memory, oblivion and identity in the Low Countries, 1566-17oo.

1 Judith Pollmann, Het oorlogsverleden van de Gouden Eeuw (Leiden: Universiteit Leiden, 2008), 9-10; Jasper van der Steen, 'Goed en fout in de Nederlandse Opstand', Holland 43 (2011), 82-97, there 87-88.

2 Jan den Tex, Oldenbarnevelt: Bestand, $1609-1621,5$ vols. (Haarlem: H.D. Tjeenk Willink, 1966), vol. 3; A.Th. van Deursen, Bavianen en slijkgeuzen. Kerk en kerkvolk ten tijde van Maurits en Oldebarnevelt (Franeker: Van Wijnen, 1998); for more concise explanations of the troubles, see: A.Th. van Deursen, Mensen van klein vermogen. Het kopergeld van de Gouden Eeuw (Amsterdam: Ooievaar, 1996), 304-311; W. Nijenhuis, 'De publieke kerk veelkleurig en verdeeld, bevoorrecht en onvrij' in P. Blok (ed.), Algemene geschiedenis der Nederlanden 6 (1977-1989); T. Kootte (ed.), Rekkelijk of precies. Remonstranten en contraremonstranten ten 
The disagreement between these theologians was about predestination and human free will. ${ }^{3}$ Arminius believed that the doctrine of predestination allowed for the human initiative to reject God's offer of salvation. Otherwise there was a risk that some people might mistakenly believe that God could be held accountable for human sin. For Gomarus, however, ideas of human involvement in the Lord's gift were anathema because they impinged on His absolute sovereignty. ${ }^{4}$ This seems a very technical doctrinal discussion, yet A.Th. van Deursen has shown that in the struggles between the supporters of these two men, not only doctrinal but also political arguments were used. ${ }^{5}$ Developing this point further, Carolina Lenarduzzi found that propagandists from both opposition groups were the first to appropriate public memories of the Revolt on a large scale to conduct their political disagreements. ${ }^{6}$

The political and religious conflicts in the Dutch Republic during the Twelve Years Truce (1609-21) thus involved a contest for the moral ownership of the communal past. Public memories of the Revolt in the 1560 s, $70 \mathrm{os}$ and $80 \mathrm{~s}$ that had been used to unite Netherlanders against the foreign enemy now became important weapons to eliminate opponents on the domestic political scene. I will build on Lenarduzzi's work and assess how this shift from external to internal usage occurred. To do so, this chapter examines the 'memory war' between Arminian 'Remonstrants' and Gomarist 'Counter-Remonstrants' in the 1610 s and offers an explanation of why canonical memories were time and again used as a rhetorical battleground on which opposing political factions carried out their disputes. The term 'memory war' used in this section of the volume refers to conflicts that are not themselves conflicts about the past but in which nonetheless the past is invoked to bolster arguments in the present. What this chapter will show is that when historical interpretations are used to support two contradictory agendas, a political disagreement can become also a conflict about the appropriation and correct reading of the past. An analysis of this phenomenon contributes to our understanding of why

tijde van Maurits en Oldenbarnevelt (Utrecht: Rijksmuseum Het Catharijneconvent, 1994); Judith Pollmann, Religious choice in the Dutch Republic. The reformation of Arnoldus Buchelius (1565-1641) (Manchester: Manchester University Press, 1999).

3 Van Deursen, Bavianen en slijkgeuzen, 228-229.

4 Nijenhuis, 'De publieke kerk', 334.

5 Van Deursen, Bavianen en slijkgeuzen, 275-309.

6 Carolina Lenarduzzi, “'De oude geusen teghen de nieuwe geusen”. De dynamiek van het oorlogsverleden ten tijde van het Twaalfjarig Bestand', Holland 43 (2011), 65-81, there 65-69. 
public memories of the Revolt remained politically relevant in the seventeenth-century Low Countries.

The rhetorical use of history in the Remonstrant and Counter-Remonstrant struggles of the 1610 s will be discussed in three sections. The first will involve the debate over which group had the oldest claim of being Reformed. The second case will deal with history as a rhetorical trap. It will examine the appropriation of Prince William of Orange's heritage by both parties. Prince William was the father of Maurice and served as the leader of the Revolt until his death in 1584. The final case will examine the use of references to the Spanish army commander Fernando Álvarez de Toledo, duke of Alba (1507-82) as the Revolt's darkest villain. Before exploring these cases, I will introduce the religious troubles briefly.

\section{Religious Troubles in the 1610 s and the Authority of History}

Around 1610, Arminian clergymen in the Reformed public church were increasingly threatened with suspension by their colleagues because of their dissenting views, notably about the doctrine of predestination. ${ }^{7}$ As a minority they began to seek support from government authorities. In January 1610, forty-four prominent Arminian clergymen presented a Remonstrance to the States of Holland, arguing for a more flexible and inclusive public church. ${ }^{8}$ Hence they became known also as Remonstrants. Holland's Advocate Johan van Oldenbarnevelt (the highest official of the province) chose to support the Remonstrants for purposes of social harmony. ${ }^{9} \mathrm{He}$ accepted their minority views in the public church as he preferred groups in society to get along rather than make a fuss about doctrinal differences. Followers of Gomarus (or Counter-Remonstrants), however, were orthodox Calvinists who rejected both the idea of a doctrinally flexible church and of government interference in the church.

Oldenbarnevelt's first major move was to force through the Resolution for the Peace of the Churches (1613), which was drafted by Hugo Grotius,

\footnotetext{
7 Judith Pollmann, Een andere weg naar God. De reformatie van Arnold Buchelius (15651641) (Amsterdam: Bert Bakker, 2000), 128-129.

8 Jonathan I. Israel, The Dutch Republic. Its rise, greatness, and fall, 1477-1806 (Oxford: Clarendon Press, 1995), 425.

${ }^{9}$ For Oldenbarnevelt's religious convictions, see: Den Tex, Oldenbarnevelt III, 1-35; for toleration as a means to preserve civic harmony: Van Deursen, Bavianen en slijkgeuzen, 251; A. Algra en H. Algra, Dispereert niet. Twintig eeuwen historie van de Nederlanden 2 (Franeker: T. Wever, 1978), 55; Joke Spaans, Haarlem na de Reformatie. Stedelijke cultuur en kerkelijk leven (The Hague: Smits, 1989).
} 
Pensionary of Rotterdam and a sympathiser of the Arminians. ${ }^{10}$ The Resolution, adopted by the States of Holland in 1614, ordered both factions to bury the hatchet and agree on a policy of peaceful co-existence within the public church. ${ }^{11}$ Holland thus mandated toleration and instructed that the issue of predestination not be discussed in church services. ${ }^{12}$ Here, the States effectively decided unilaterally that the Arminian stance on predestination was acceptable within the public church. CounterRemonstrants saw this action as an undesirable compromise on their faith and as an intolerable intervention of the state in church affairs. ${ }^{13}$

In the course of the 1610 s, a string of political associations came to be attached to the religious disagreements. Counter-Remonstrants, for instance, argued that the teachings of their Arminian opponents smacked of Papist sympathies or even of 'Pelagianism'. ${ }^{14}$ If a believer could himself influence God's offer of election by doing good deeds, what then distinguished the Remonstrants from evil Catholics? ${ }^{15}$ Furthermore, Gomarists increasingly regarded the Remonstrants as unpatriotic because they sought support from the Advocate Johan van Oldenbarnevelt. Oldenbarnevelt's patriotic credentials had been tarnished by his successful efforts for the ceasefire with Spain. At the height of the conflict from 1617 onwards, Counter-Remonstrant propagandists even raised suspicions that Oldenbarnevelt was in fact a crypto-Catholic himself and in league with the Catholic powers France and Spain.

10 States of Holland, Resolvtie vande doorluchtige moghende heeren Staten van Hollandt ende West-Vrieslandt (The Hague, 1614), Kn. 2109.

11 Resolutie Vande Doorluchtige Moghende Heeren Staten van Hollandt ende WestVriesland tot den Vrede der Kercken (The Hague, 1614).

12 Kootte (ed.), Rekkelijk of precies, 18.

13 See for instance: Jacobus Trigland, Antwoorde op dry vraghen, dienende tot advijs in de huydendaechse swaricheden (Amsterdam, 1615), Kn. 2191; Vincent van Drielenburch, Cort examen ende sententie Johannis Vtenbogaerts over seker tractaet, welckes tytel is: Verdediging van de resolutie [...] der Staten van Hollandt [...]. totten vrede der kercken (Amsterdam, 1615), Kn. 2195 .

14 See, for instance, anonymous, Een kort en waerachtich verhael, wat voor een grouwelijck ghevoelen dat de Arminianen, Vorstianen, ofte nieuwe Arrianen, Pelagianen, Socinianen, Samosatianen ghesocht hebben in de Ghereformeerde Kercke in te voeren, en in kort hier teghen gestelt het ghevoelen der Ghereformeerde Kercke (s.l., 1612), Kn. 2009; Jacobus Trigland, Kerckelycke geschiedenissen begrypende de swaere en bekommerlijcke geschillen, in de Vereenigde Nederlanden voor-gevallen, met serselver beslissinge, ende aenmerckingen op

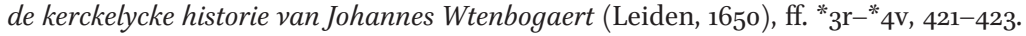

15 Arminians, in turn, also accused Counter-Remonstrants of Papist tendencies. The author of the following pamphlet calls the Gomarist clergymen who opposed government interference in church order 'Jonge Pausen vanden Ouden Paus van Rome' or 'young popes of the old pope of Rome'; Robbert Robbertsz Le Canu, Ratelwachts roeprecht, tegent boeck

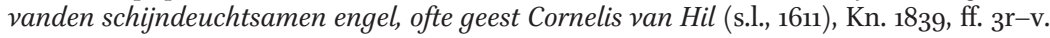


In January 1617, Prince Maurice unambiguously chose side in the conflict and began supporting the Counter-Remonstrants. Oldenbarnevelt and Prince Maurice both lived in Arminian-dominated The Hague. Tensions rose when the Counter-Remonstrants, who refused to attend the Arminian services, wanted a church building to be allocated to them. In the summer they had still attended Gomarist services in neighbouring Rijswijk, but the winter rendered such Auslauf less attractive, especially for the young and elderly. ${ }^{16}$ Things changed when Oldenbarnevelt asked the stadholder's assistance in keeping the Counter-Remonstrants from causing unrest in the city. ${ }^{17}$ Maurice was invited to appear at a meeting of the Delegated Councillors, together with the High Council, the Court of Holland, the Audit Chamber and the magistrates of The Hague on 13 January $1617 .^{18}$ The English ambassador Sir Dudley Carleton wrote a biased report of this assembly. According to his account, the regents asked Maurice to prevent the Counter-Remonstrants from causing disturbances and, if necessary, to use his own princely guard or forces from outside the city to keep them in check. Maurice declined, arguing that his guard was there only to protect his own person and that military forces were for the defence of the country against foreign threats. In reaction to the continued pressure of the magistrates, Maurice 'called for the register-book, wherein his oath was set down, which he took in the year 86; at which time he entered into the charge he now holds for the service of the state'. ${ }^{19}$

The prince ordered the register-book for a purpose, it 'being read in all their presences, and therein this article noted in particular, that both he and the states do mutually bind themselves, even to the last drop of blood, for the defence of the Reformed religion, which was the first ground of their quarrel, and for which his father lost his life' ${ }^{20}$ Carleton never made any attempts to disguise his sympathy for the Counter-Remonstrant camp,

16 Den Tex, Oldenbarnevelt, vol. 3, 439; for the term 'Auslauf', see Benjamin Kaplan, Divided by faith. Religious conflict and the practice of toleration in early modern Europe (Cambridge Mass.: Belknap Press, 2007), 145.

17 A.Th. van Deursen, Maurits van Nassau. De winnaar die faalde (Amsterdam: Bert Bakker, 2005), 256.

18 Den Tex, Oldenbarnevelt, vol. 3, 441; the term 'Delegated Councillors' is a translation of 'Gecommitteerde Raden'. This institution was the executive committee of the States of Holland: Robert Fruin, Geschiedenis der staatsinstellingen in Nederland tot den val der Republiek (The Hague: Martinus Nijhoff, 1980), 224-226.

19 Dudley Carleton to Ralph Winwood, 14 January 1617, in Letters to and from Sir Dudley Carleton, Knt. during his embassy in Holland from January 1615/1616 to December 1620 (London, 1775), 87.

20 Ibid., 87. 
but if he can nonetheless be trusted in his account, Maurice invoked the memory of his deceased father William of Orange to point out that the Revolt had been foremost a struggle for the Reformed religion. ${ }^{21}$ 'Sitting in the same chair which was anciently the place of the counts of Holland, [...] [where] he hath not been called before this time since 86', the Prince ordered the magistrates to assign a building to the Counter-Remonstrants and allow them free worship. ${ }^{22}$ The problem with this description is that Maurice's oath did indeed include a pledge for protection of the 'true Reformed religion', but strictly speaking it did not specify this to be the Counter-Remonstrant variant of the faith. ${ }^{23}$ Unfortunately, there is no way of knowing whether the Prince indeed acted according to Carleton's description. It is obvious, however, that the ambassador thought it a good thing to have the Orange dynasty's support for the Counter-Remonstrant cause.

Reliable or not, Carleton was an astute observer of Dutch politics and his accounts tend to be accurate reflections of Counter-Remonstrant sentiments. He wrote to the English secretary of state that the original cause of this disorder is easily discovered to be Arminianism: the effects will be faction in the state, and schism within the church'. ${ }^{24} \mathrm{He}$ continues his report ominously, writing that the factions begin to divide themselves betwixt his excellency and monsieur Barnevelt, as heads, who join to this present difference their antient quarrels' ${ }^{25}$ These ancient quarrels were about the negotiation of the truce with Spain and the Habsburg Netherlands. More recently, Maurice had also fallen out with Oldenbarnevelt over the Advocate's wish to support the pro-Spanish and Catholic French government in its domestic struggles against Huguenot rebels, support which Maurice disapproved of. ${ }^{26}$ To underline the urgency of his concerns, Carleton recounts the washing ashore of three whales-'a popular vanity of prognosticating change', which nevertheless he 'cannot ommit'. ${ }^{27}$ Two of them beached on the Island of Brill 'in the very places and instant

21 See also J. Bax, Prins Maurits in de volksmeening der 16e en 17e eeuw (Amsterdam: H.J. Paris, 1940), 25; Den Tex, Oldenbarnevelt III, 443-444.

22 Carleton to Winwood, 14 January 1617, in Letters to and from Sir Dudley Carleton, 87.

23 Hugo Grotius, Verantwoordingh van de vvettelijcke regieringh van Hollandt ende WestVrieslant (Paris, 1622), 121; see also: C.P. Hofstedde de Groot, Honderd jaar uit de geschiedenis der Hervorming in de Nederlanden (1518-1619) (Leiden: A.W. Sijthoff, 1883), 403.

24 Carleton to Winwood, 14 January 1617, in Letters to and from Sir Dudley Carleton, 88.

25 Ibid., 89 .

26 Den Tex, Oldenbarnevelt, vol. 3, 444.

27 Carleton to Winwood, 14 January 1617, in Letters to and from Sir Dudley Carleton, 89. 
time of these tumults'. Brill had been the place where the rebels against Spain first took control in $\mathbf{1 5 7 2}$. Carleton is even more surprised because 'it is remembered, that at the first breaking out of these country wars, there were two of the like bigness driven on shore in the river of Schelde below Antwerp, and at the framing of the Truce one here in Holland' ${ }^{28}$

On 23 July 1617, Maurice and his princely entourage openly attended Counter-Remonstrant services in the Kloosterkerk in The Hague, defying his own Arminian preacher Uytenbogaert. ${ }^{29}$ Johan van Oldenbarnevelt saw the stadholder's behaviour as the provocation it was likely intended to be. Eager to restore his damaged authority, he showed his muscle and encouraged the States of Holland to adopt the Scherpe Resolutie or sharp resolution. This measure allowed cities to employ their own waardgelders, mercenary soldiers, to enforce toleration of religious nonconformists within the public church. ${ }^{30}$

The British ambassador was one of the most vehement opponents of this measure. On 6 October 1617 , he felt compelled to speak out against government support for the Remonstrants and addressed the States General who were assembled in The Hague. The text was subsequently printed and distributed. ${ }^{31}$ Carleton explains that 'to seeke the originall of this euill any further backe then the time of Arminius Professor at Leyden, were to disguise the fact'. He wanted to make clear that not the doctrinal documents of the Reformed church were the source of all troubles but that Arminius was the culprit. ${ }^{32}$ He provides a succinct history of the rise of the troubles and deplores the 'animosities and alterations betweene the magistrates, sowernesse and hatred amongst the people'. Then, he portrays nostalgically the situation before the troubles. Before the rise of Arminius and his schismatic behaviour, there had been 'union in the church and estate; good correspondence between the magistrates; Christian love

\footnotetext{
28 Ibid., 89.

29 Den Tex, Oldenbarnevelt, vol. 3, 490; Poelhekke, Frederik Hendrik, 65-66; Van Deursen, Maurits, 258.

${ }^{30}$ Van Deursen, Bavianen en slijkgeuzen, 271-272.

31 Carleton to Thomas Lake, 22 November 1617, in Letters to and from Sir Dudley Carleton, 206-207; Taurinus, Weegh-schael, om in alle billickheydt recht te over-vveghen de oratie vanden [...] heere Dvdley Carleton [...] inde vergaderinghe der [...] Staten Generael (s.l., 1617), 4.

${ }^{32}$ Dudley Carleton, The speech of Sir Dudley Carlton lord ambassadour for the king of Great Britaine, made in the assembly of the lords the Estates Generall of the vnited provinces of the Low Countries. Being assembled at the Haghe. Touching the discord and trovbles of the church and policie, caused by the schismatic doctrine of Arminivs (London, 1618), 2.
} 
and charitie among the people'. ${ }^{33}$ To solve the problems, Carleton urged the States General to hold a national synod: 'I say nationall, because the euill being passed from province to province, a provincial synode is not sufficient'. ${ }^{34}$

A national synod had been a tricky subject from the start of the religious troubles. First of all, delegating church affairs to a national synod was placing the matter out of the hands of the provincial government, and that was exactly what the Arminians did not want. As a minority, they needed government protection to counterbalance the orthodox Calvinist majority within the Reformed church. Furthermore, a national synod was seen by the majority of cities in Holland as a challenge to provincial sovereignty. ${ }^{35}$ Carleton waves these objections aside. He begins by making a rhetorical appeal as a foreigner: 'I will not play the busie-body in aliena Republica, therein to iudge how much euery prouince in particular ought in such occasions to yield to the publike'. And then he proceeds to do just that: "let them not forget the oath by which they are consolidated and closed up into one body which is the vnion of Vtrecht grounded upon religion'. ${ }^{36}$

The Union of Utrecht (1579) was, de facto, the constitution of the Republic. And although it guaranteed the sovereignty of each province, especially in matters of religion, 'this ought to bee vnderstood'-according to Sir Dudley-'soundly for the maintenance of the pure \& sincere religion'. The articles which prescribed provincial autonomy in matters of religion, notably article 13, were originally intended to allow Holland to uphold Reformed purity 'without being exposed to the will and pleasure of the other provinces which at that time were not reduced to such a union of the Church as they enjoy at this present'. ${ }^{37}$ Here, Carleton refers to the time around 1580 when, in many provinces in the east and south of the rebel United Provinces, the Reformed church was less developed and under constant pressure from Habsburg troops who were trying to reconquer the territory, quash the insurrection and 'recatholicise' the population. Now, the situation was different since the Reformed church had

33 Ibid., 5 .

34 Ibid., 6.

35 Resolutiën der Staten-Generaal. nieuwe reeks, 1610-1670: derde deel, 1617-1618, ed. J.G. Smit (The Hague: Martinus Nijhoff, 1975), 286.

36 Carleton, The speech, 7.

37 Ibid., 7; see for article 13 of the Union of Utrecht: Simon Groenveld, Unie-BestandVrede. Drie fundamentele wetten van de Republiek der Verenigde Nederlanden (Hilversum: Verloren, 2009), 65. 
become the established public church in all of the provinces. The original intentions of the Union of Utrecht's articles about provincial autonomy regarding religious matters had been overtaken by the new reality of Calvinist hegemony.

It was in this historical setting that propagandists from the Remonstrant and Counter-Remonstrant camps tried to convince the population of the validity of their viewpoints. Increasingly, secular political arguments complemented doctrinal arguments, and memories of the Revolt became political weapons.

\section{Who Was First?}

Counter-Remonstrants accused their Arminian opponents of introducing novelties into the public church. The severest allegation was that Arminians sought to dilute the most important doctrinal documents of the Reformed church in the Netherlands so that Arminian ideas about predestination could become accepted practice. Ever since the Synod of Emden in 1571, these documents were officially the Heidelberg Catechism and the Belgic Confession, and it was the duty of consistories and classes to uphold them. ${ }^{38}$ Counter-Remonstrants argued that both standard documents had been fought for in the war against Catholic Spain. They felt that changing the catechism and confession would be tantamount to casting off the achievements of the Revolt. ${ }^{39}$

Arminians found a way around the Counter-Remonstrant criticism that they sought to introduce novelties by emphasizing that although, as a religious group, they had come into existence only in the early seventeenth century, they acted more in the spirit of the Reformation than did their adversaries. ${ }^{40}$ Arminians claimed, for instance, that the authority of the Bible was far more important than the Reformed church order. Their Gomarist adversaries' claim of antiquity was clearly nothing compared to the antiquity and status of the Bible. Prince Maurice's Remonstrant court

38 Trigland, Kerckelycke geschiedenissen, ff. * $3{ }^{\mathrm{r}}-{ }^{*} 4 \mathrm{v}, 18-19$.

39 [Johan Casimir Junius], Wederlegginge van de Weegschaal onlangs uytgegeven tegens d'oratie des ed. heere Dvdley Carletons (s.l., 1618), 154.

40 See for instance the discussion about the supposed nieuwlichterij of the Arminians in Uytenbogaert, Copye and its retort in [ Jacobus Trigland], Klaer |ende grondich teghenvertoogh, van eenighe kercken-dienaren van Hollandt ende West-Vrieslandt, gestelt tegen seker vertoogh der remonstranten (Amsterdam, 1617); see also: Van Deursen, Bavianen en slijkgeuzen, 230. 
chaplain Johannes Uytenbogaert (who had been one of the first authors of the 1610 Remonstrance) used this argument. In one of his pamphlets he sneers: "The history of 40 years on which the Counter-Remonstrants pride themselves is real novelty compared to the history of Holy Scripture and the first Christendom'. ${ }^{41}$

Interestingly, though, the rhetoric of seniority proved irresistible even for the learned Arminian clergyman Uytenbogaert. To strengthen his argument, he tells the reader that 'there are in these lands many preachers now dead and some still alive, old men: who have declared and still declare never to have had different sentiment than the current Remonstrants do now' ${ }^{42}$ He pointed to the example of Rotterdam preacher Jan Ysbrantsz, who from the very beginning of the Reformation in that city 'hearing of Calvin's predestination already at that time publically refuted it, and that some old members noticing that some others sought to introduce it, departed for that reason from the church'.43 And in the city of Hoorn, Clement Maertensz, one of the oldest retired clergymen in Holland, 'frequently declared that from the beginning of his service onwards he had and had learned no other feeling regarding the predestination than that of Melanchton, and to have learned such from Hardenberg, one of the very first preachers of our reformation in Emden' ${ }^{44}$ Hence the Counter-Remonstrant claim of being more truly Reformed was, Uytenbogaert felt, inconsistent with the evidence from the past. But perhaps more importantly, he felt it was necessary to draw from the recent past to make this statement.

\section{What would William of Orange Do?}

By accusing them of jeopardizing the religious achievements of the Revolt, Counter-Remonstrants had pushed Arminians into a defensive mode. In search of an effective offensive strategy, Arminian clergyman and propagandist Jacob Taurinus from Utrecht expanded the rhetorical repertoire of the Remonstrants by appropriating the Revolt's secular heritage. In one of his pamphlets, Taurinus addresses the allegorical 'Maiden of Holland' and

41 Johannes Uytenbogaert, Copye van seker vertooch onlanghs bij eenighe predicanten der ghereformeerde kercke ghedaen [...]. roerende de oudtheyt vande gereformeerde leere (Delft, 1617), f. a3r.

42 Ibid., f. a4v.

43 Ibid., ff. a4v-bir.

44 Ibid., f. bir. 
seeks to sway her to the Remonstrant cause. First of all, he reminds her of the province's illustrious history of independence. 'Eight hundred years and more it is past that you have never been overlorded (although fiercely fought against)'. Is Holland now to abandon this proud tradition? 'That I think not: thou has suffered too much and fought too bloodily for more than forty years'. ${ }^{45}$ The implication is that Remonstrants should be considered the true inheritors of the Revolt's legacy.

In 1617, Taurinus wrote another influential pamphlet in which he adopted the national hero William of Orange as the retrospective protector of the Remonstrant cause. ${ }^{46}$ According to Taurinus, a reconstruction of Prince William's motivation for entering the war could be used to prove that he did not act primarily from religious motives. The author could thus show that the Counter-Remonstrant pursuit of Calvinist orthodoxy contradicted the original intention of the Revolt. To prove his point, he cites well-respected histories and in doing so does not shy away from recalling painful episodes such as the iconoclastic furies of 1566. During these furies, Catholic church property was destroyed by Protestant fanatics. For Taurinus, the episode confirmed that religious extremism leads to unrest. He notes that, at the time, William of Orange 'could not condone the breaking of the images [...] for which reason he also did not remain without discredit or slander among part of the zealots' ${ }^{47}$ By 'zealots', Taurinus refers to militant Calvinists like Jan van Hembyze and Peter Dathenus from Ghent who had criticised Prince William's confessional elasticity in the 1570 s and 80 . The Prince, then, had denounced religious extremists, even though it had made him unpopular among some of his supporters.

45 [Jacobus Taurinus], Ernstighe aenspraeck, aen de maeght van Hollandt (s.l., 1917), 3.

46 [Jacobus Taurinus], Na-Sporingh / hoe ende in vvat manieren, De door-luchtighe, ende hoogh-ghebooren vorst, de prince van Orangien, hooghloffelijcker memorie, de beschermenisse deser landen heeft aenghenomen, om de Nederlantsche Belijdenisse / als in allen deelen met Godts woordt accorderende / te mainteneren: en t'gevoelen der Contra-Remonstranten, int stuck vande predestinatie met den aencleven vandien, als Schrifmatich over al in te voeren (1617); according to Carolina Lenarduzzi this is the first time that the legacy of William of Orange is invoked for political purposes in the religious polemic during the Twelve Years Truce: Lenarduzzi, ' "De oude geusen teghen de nieuwe geusen"', 73; yet, earlier instances are known; on the Remonstrant side: Johannes Uytenbogaert, Verdedigingh vande resolvtie der [...] Staten van Hollant ende West-Vrieslant, totten vrede der kercken, teghen seker libel, gheintituleert Antwoort op drie vraghen (Amsterdam, 1615), f. ***3v; and on the CounterRemonstrant side: Van Drielenburch, Cort examen, f. bir.

47 [Taurinus], Na-Sporingh, 9 . 
The pamphlet by Taurinus was not received well at all among CounterRemonstrants. The English ambassador in The Hague, especially, was not pleased. He called it a book of 'vulgar language in conformity to the discourse of mons. Barnevelt'. Like other Gomarists, he lambasted Taurinus' assertion that the Revolt was 'for civil respects only', and he claimed that this Arminian wanted 'to wound count Maurice through his father's sides'. In response, the ambassador insisted that William of Orange fought the war against Spain for three reasons: the inquisition, the building of citadels and the injustice, all three of which, he wrote, 'are now again practiced by the Arminian faction'. ${ }^{48}$ Here we see that the ambassador gave his adversaries a taste of their own medicine. He came up with his own interpretation of the past in reaction to the Arminian propaganda.

The anonymous author of a particularly popular Counter-Remonstrant pamphlet The Right Track was also disgusted by Taurinus' interpretation of history, stating: 'When I saw the title, I thought that a grateful Netherlander sought to circulate the highly praiseworthy deeds and name of the [...] Prince'. That first impression proved false, however, for after having read the booklet, the anonymous author 'found that it was made in disparagement of his Princely Excellency's well-deserved and immortal honour'. ${ }^{49}$ What stands out in the anonymous author's text is the elaborate scholarly apparatus. Just like Taurinus, he cites William of Orange's famous Apology (1581) multiple times. In 1580 Prince William had been declared an outlaw by Philip II of Spain due to his treasonous conduct. To exonerate himself of the charges raised against him, the Prince had written an apologia. ${ }^{50}$ But the anonymous author disagrees with Taurinus' interpretation of the text and sets himself apart by his annotation.

In the disputed section, William of Orange writes: 'I mind not here (my Lords) to enter into this question, which is the true Religion'. ${ }^{51}$ Yet, where Taurinus had left it at that, the anonymous author reveals that the Prince's subsequent words clarify that he merely thought religion was the domain of clergymen and therefore fell outside his own area of expertise. The view that religion was, according to Prince William, best left to the church must

48 Carleton to Winwood, 30 October 1617, in Letters to and from Sir Dudley Carleton, 196.

49 Anonymous, De rechte spore ende aenwijsinghe, dat de [...] prince van Orangien [...] de bescherminghe der Nederlanden heeft aenghenomen voor de waerachtige religie, tegen de tyrannije der Spangiaerden (s.l., 1617), 3.

50 William of Orange, Apologie, ofte verantwoordinghe des doerluchtighen ende hooghgeborenen vorsts ende heeren, heeren Wilhelms [...] teghen den ban [...] ghepubliceert by den coningh van Spaegnien (Leiden, 1581).

51 Ibid., 5 . 
have been appealing to Counter-Remonstrants, who disapproved of government interference in the church. For the reader who wanted to check for himself what William had actually written, the anonymous author refers to: 'page 98 [of the Apology] that one can find in the last Edition printed in Leiden Anno 1609 or in the one printed in 1581 with Charles Silvius with the biggest Type [on] page 165 or with the other Type [on] page $111{ }^{5}{ }^{52}$ By citing multiple editions, the author lends weight to his argument and undermines that of his adversary. He enables his readers to look up his references and verify the authenticity of the citations, while pointing to the sloppy and biased Arminian interpretation of the source.

Apart from his view that Taurinus misinterpreted the source, the author points out that in other writings the Prince's concern for the maintenance of the Reformed religion becomes abundantly clear.

If he were to research the many old writings, commissions, and instructions by the Prince of Orange in the years $1567,1568,1569,1570,1571,1572$, and subsequent years, until he was killed so cruelly and murderously [...] he would find this to have been his chief aim, above all to further the honour and service of God, to protect the oppressed Christians, and maintain the privileges and liberties of these lands. ${ }^{53}$

Again like Taurinus, to bolster his agenda he draws on the well-known historians Pieter Bor and Emanuel van Meteren who wrote standard works about the Revolt. ${ }^{54}$ Taurinus refers to these historians to demonstrate, for example, that William of Orange respected the authority of the provincial state assemblies, even when they were dominated by Catholics. ${ }^{55}$ To him, this was evidence that Orange could not have been driven primarily by religion and that it was religious freedom the Prince was after. The author of The Right Track read Bor and Van Meteren differently and concludes that William of Orange struggled 'against the duke of Alba and his Spanish and Hispanised followers', who in turn waged war against the heretics. Thus, William fought not for religious freedom but rather to defend the true Reformed religion. ${ }^{56}$ Such an interpretation placed the old prince in an entirely different light, namely as a protector of the faith and more specifically as the guardian of the Counter-Remonstrant profession.

52 Ibid.

53 Ibid., 13 .

54 Pieter Christiaensz Bor, Oorspronck, begin ende aenvang der Nederlantscher oorlogen, beroerten ende borgerlijcke oneenicheyden (Utrecht, 1595); Emanuel van Meteren, Belgische ofte Nederlantsche historie, van onsen tijden (Delft, 1599).

55 Taurinus, $\mathrm{Na}$-Sporingh, 7.

56 Ibid., 12-13. 


\section{The Trap of History}

We have seen how a group who took the initiative of referring to the past to argue a case practically compelled its opponent to do the same. Another good example of this phenomenon is the way comparisons with the duke of Alba served to vilify one's opponent. In the Counter-Remonstrant print entitled Image of the Old and New Time we see the Advocate Johan van Oldenbarnevelt presiding over a table in the presence of several of his advisors, one of whom is whispering evil advice into his ear (figure $1 b$ ). In the text beneath the picture, two viewers discuss what they see. One of them exclaims: 'Hang on! Who do I see there? [...] Hey mate, look at it, how well it is cut: Hey let us have a look: is it not Barnevelt? The illustrious president, full of power and great force?'. ${ }^{77}$ The other, however, replies: 'Tis a president alright, but he is named the duke of Alba'. ${ }^{58}$

And indeed, by flipping the top half of the picture the duke of Alba suddenly replaces Oldenbarnevelt (figure 1a). Alba was one of the darkest characters in the canonical narrative about the Revolt in the Dutch Republic. At the beginning of the conflict in the 1560 s and 1570 , he and his Council of Troubles condemned thousands of Netherlanders to death. The background reveals the Grand Place of Brussels in 1568 where the prominent counts of Egmont and Horne are about to be executed as political dissidents. The two persons in the text squabble for a bit about their discrepant interpretations, and then a third person enters the room. He understands the confusion and explains that there is, after all, not much difference between Oldenbarnevelt and the duke of Alba.

At the height of the conflict between the Remonstrants and CounterRemonstrants, Maurice marshalled all the support he could get, charged Johan van Oldenbarnevelt with treason and ordered the Advocate's arrest. The statesman, who was then seventy-one years old, was beheaded on 13 May 1619. A few months before, the much disputed National Synod had assembled at Dordrecht. It condemned Arminian theology and ordered the expulsion and exile of all Arminian clergymen who persisted in their doctrinal deviance. In the face of more persecutions, Remonstrant authors, too, began to draw analogies with the duke of Alba. It was, for example, Alba who in 1568 had captured one of Oldenbarnevelt's predecessors:

57 Anonymous, Afbeeldinghe van den ouden ende nieuwen tijdt / Met een t'samenspraeck van Beste-maet en Botte-maet (s.l., 1618).

58 Ibid. 


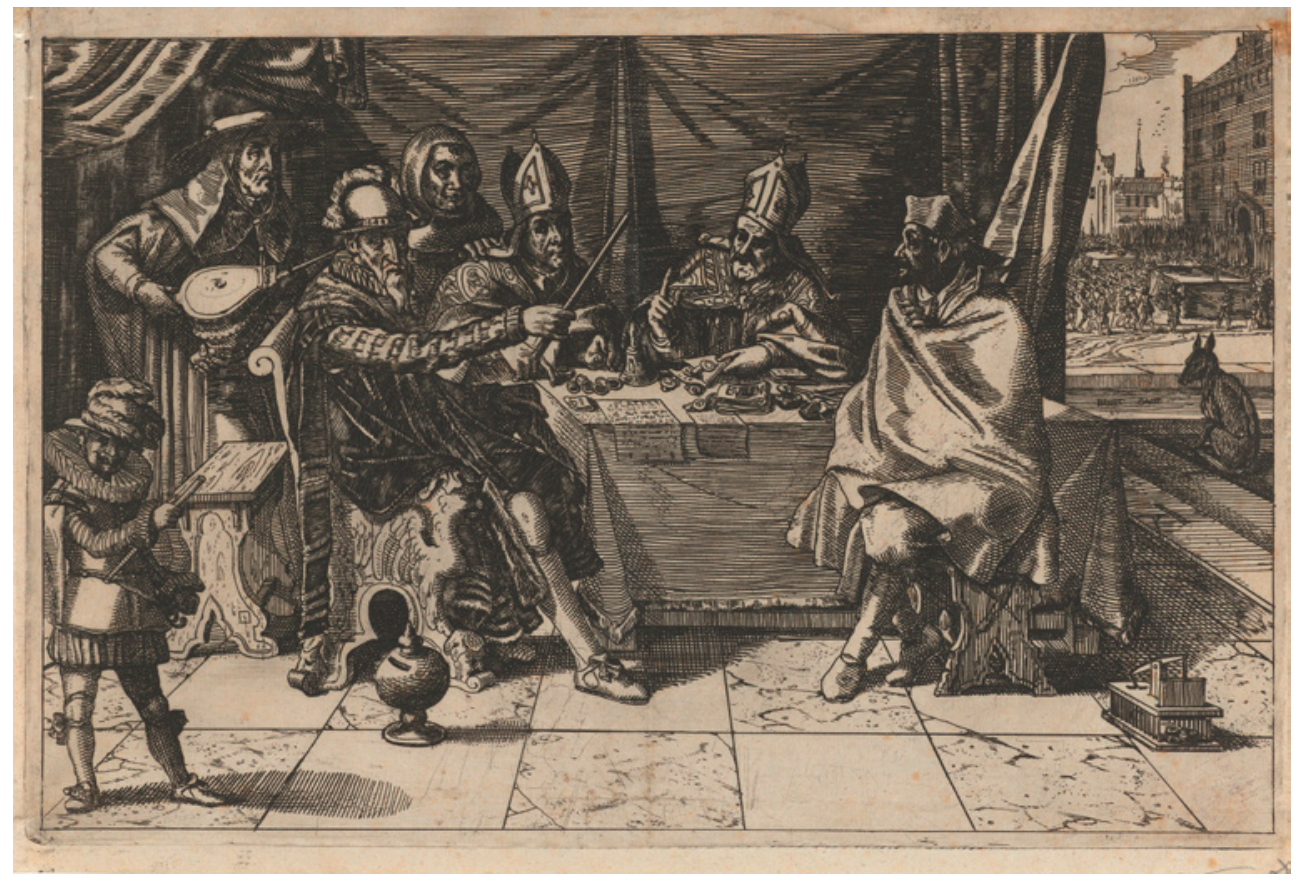

Fig. 1a. Image of the Old and New Time, Rijksmuseum Amsterdam.

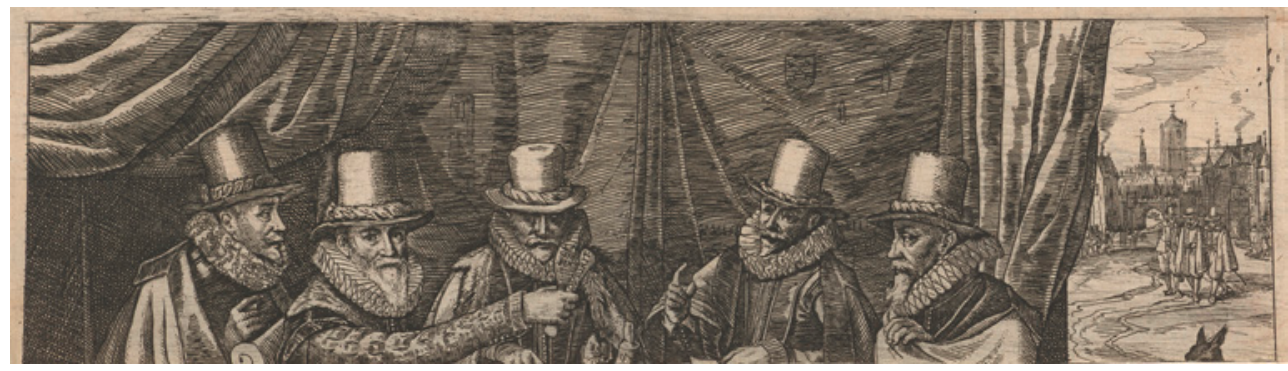

Fig. 1b. Detail of fig. 1a. By flipping over the top half the duke of Alba appears in conference with his Council of Troubles. 
Advocate Jacob van den Eynde. ${ }^{59}$ The duke, whose cruel image had been used to convince Netherlanders to keep on fighting Spain, was now deployed by Remonstrants for a new purpose: to show that the liberty of conscience was being squandered.

This argument can be illustrated by an account of a Counter-Remonstrant disruption of an Arminian service. An anonymous author in 1619 criticised Counter-Remonstrant measures against clandestine Remonstrant preaching just outside Rotterdam, where Arminianism had also been banned. In his text, he denounces the hypocrisy of the CounterRemonstrants: 'how often they generally shouted against the procedures against them by the duke of Alba [...] is still fresh in the memory'. But since the 'bloodthirsty Calvinists or Gomarists [...] by force of arms, have gained the upper hand' not much was left of these hard-won liberties. ${ }^{60}$ In a handwritten propagandistic poem circulating in The Hague, the juxtaposition between past and present is made even stronger. 'The duke of Alba has exercised tyranny in Holland / On equal terms the Prince [Maurice] establishes dominion / You ask why it happens? / I say, that in the prince of Orange / the duke of Alba's soul has come from Spain'.61

\section{Conclusion}

During the Twelve Years Truce, Remonstrants and Counter-Remonstrants contested the moral ownership of the communal past. They both drew from the inclusive canonical narratives about the Revolt to bolster their arguments and thereby turned the past into a rhetorical battleground. This article has shown how a canonical narrative that was aimed at blackening the foreign enemy could become the stake of disagreements in domestic politics.

There are several reasons why public memories of the Revolt were used. In the first place, an important condition for using episodes of the Revolt successfully as a political weapon was that they were widely known and recognised as important. Since the episodes had already reached canonical status in the discussions about war and peace, people could easily understand or at least identify with the historical references, which

59 Den Tex, Oldenbarnevelt, vol. 3, 626.

60 Anonymous, Sommier verhael van de wreede handelinghe der bloet-dorstighe Calvinisten, ghepleeght teghen de Remonstranten buyten Rotterdam (s.l., 1619), 3-4.

61 Cited from Van Deursen, Bavianen en slijkgeuzen, 360. 
accordingly carried rhetorical value. Secondly, the secular history of the Revolt was just another way of appealing to a more general audience. At the beginning of the religious troubles, academic discussions about doctrine prevailed. But as religion and politics became even more entangled than usual, both factions needed to address a more general audience that was not necessarily trained in theology. The widely known history of the Revolt was something many people could associate with, and it could therefore serve as an effective frame of reference. Thirdly, I found that the appropriation of memories of the past by one party forced the other party to do the same, however reluctantly. This resulted in two alternative interpretations of history and a memory war. Ultimately the 'winner' of this memory war was decided not by rhetoric but by 'real' actions. Due to the ultimate victory of the Counter-Remonstrants, the canonical narratives about the Revolt became associated not only with anti-Hispanism but also with Calvinist orthodoxy and the prince of Orange, giving the canon an internal religious and political flavour which, as an inclusive anti-peace narrative, it had previously lacked. 
Erika Kuijpers, Judith Pollmann, Johannes Müller, and Jasper van der Steen - 978-90-04-26125-9 Downloaded from Brill.com04/26/2023 11:57:20AM via free access 


\title{
'YOU WILL SEE WHO THEY ARE THAT REVILE, AND LESSEN YOUR... GLORIOUS DELIVERANCE'. THE 'MEMORY WAR' ABOUT THE 'GLORIOUS REVOLUTION'
}

\author{
Ulrich Niggemann
}

Revolutions tend to create new pasts, or, in the words of Melinda Zook: 'Revolutionaries of modern times often imagine themselves not only as creators of a new future, but also as constructors of a new past'. ${ }^{1}$ In fact, revolutionaries often legitimate their breach with the past by reshaping memories. This applies not only to modern times but also to earlier revolutions such as the 'Glorious Revolution' in England when King James II was dethroned in 1688-89. Memories of the Revolution itself and of the events immediately preceding it soon became the subject of memory politics and of controversy. The newly established regime of William III and Mary II sought legitimacy by influencing memories. At the same time, groups and factions tried to establish competing memories to achieve their own political aims and to forge new identities.

This article analyses the attempts of the state as well as several pressure groups to shape the public memory of the Glorious Revolution. It examines how distinct narratives of the Revolution refer to different political and/or religious identities. Moreover, in the course of a 'memory war' that began during the reign of Anne (1702-14), memories of 1688-89 were used as political weapons by rival parties. It is important to note that this development took place within the camp of the supporters of the Revolution. The controversy concerned not the legitimacy of the event (that was a separate issue) but the right of the contending parties to appropriate the Revolution. 'Memory war' as understood in the present article, therefore, deals with the struggle over assigning meanings to and exercising control over public memories of the Glorious Revolution. Naturally, the scope of the present article is limited, and it will, therefore, focus on how, after the Glorious Revolution, the English state established patterns for narratives

\footnotetext{
${ }^{1}$ Melinda Zook, " "The Bloody Assizes”. Whig martyrdom and memory after the Glorious Revolution', Albion 27 (1995), 373-396, there 373.
} 
of the Revolution and how different actors used these narratives. It also gives some examples of the struggle over meaning and appropriation, but it cannot offer a broader discourse analysis of the controversies concerning the Revolution and its consequences. ${ }^{2}$

\section{The Role of the State}

Attempts to shape memories and to give meaning to the events from October 1688 onwards can be observed even during the interregnum after James' flight in December 1688. At that moment, the Crown was weak and government control of the press nearly collapsed. However, William III and his nearest entourage tried to influence public opinion through intense propaganda efforts. Immediately after William's landing, his printed declarations distributed images and interpretations of what was happening. ${ }^{3}$ After 22 January 1689, the Convention, too, contributed to the establishment of an official view of the Revolution stating that James had abdicated his position, leaving the throne vacant. Although a contract between James and the people was mentioned, the breach of this contract was not offered as the rationale on which the abdication was based. ${ }^{4}$

Even before the meeting of the Convention, additional strategies were developed. One of the key figures of the propaganda efforts was the future bishop of Salisbury, Gilbert Burnet, who not only participated in drafting William's 'Declaration of Reasons' but also organised a service of thanksgiving in Exeter Cathedral when William arrived there. After William's arrival in London, Burnet preached in St James' Palace, where he, according to Tony Claydon, 'set the tone' for sermons on the Revolution for the next couple of years. ${ }^{5}$ In his sermon, Burnet argued that William's intervention was brought about by divine providence to rescue

2 A book on the memory and use of the 'Glorious Revolution' in early eighteenthcentury England is in preparation by this author.

3 The 'Declaration of his highness William Henry, by the grace of God, prince of Orange, etc., of the reasons inducing him to appear in arms in the Kingdom of England' (1688) is edited as, The eighteenth-century constitution 1688-1815. Documents and commentary, ed. Ernest N. Williams (Cambridge: Cambridge University Press, 1960), 10-16.

4 David L. Jones, A parliamentary history of the Glorious Revolution (London: Her Majesty's Stationery Office, 1988), 20-38.

5 Tony Claydon, William III and the Godly Revolution (Cambridge: Cambridge University Press, 1996), 102; and generally on the role of Burnet ibid., 24-63; Tony Claydon, 'William III's Declaration of Reasons and the Glorious Revolution', The Historical Journal 39 (1996), $87-108$. 
England from Roman Catholicism. ${ }^{6}$ This line of argument was further developed in sermons given on the thanksgiving days ordered by the Convention for 31 January and 14 February 1689.7 For these services of thanksgiving, a Form of Prayer was composed by some of the bishops, stressing how God's favour advanced the Revolution and characterising William as God's instrument. ${ }^{8}$ Furthermore, later in 1689 , when the new monarchs were seated on the throne, an extraordinary liturgy for the $5^{\text {th }}$ of November 1689 was inserted into the Book of Common Prayer, focusing on the landing of William of Orange in England on that day and stressing the coincidence with the date of 'deliverance' from the Gunpowder Plot. ${ }^{9}$ This thanksgiving was perpetuated in 1690 , thus establishing the $5^{\text {th }}$ of November as the central commemoration day of the Glorious Revolution. ${ }^{10}$

Thanksgiving days, fast days, prayers and sermons remained a central part of government propaganda, but additionally a broad range of media such as pamphlets, prints and medals were used to stress the legitimacy of the reign and to promote compliance with the new regime. ${ }^{11}$ These media helped to shape images of the new king and queen as well as of the revolutionary events of 1688-89. It is, however, remarkable that these images were by no means unambiguous. Government propaganda did not provide any single way of depicting the Revolution - the constitutional language of William's declaration was used side-by-side with the providential and other languages. ${ }^{12}$ By providing a platform for a negotiation

6 Gilbert Burnet, A sermon preached in the chappel of St. James's, before his highness the prince of Orange, 23d of December, 1688 (London, 1689). Cf. Claydon, William III, 31-32.

7 Order of the House of Lords, 22 January 1689, Journal of the House of Lords, beginning anno primo Jacobi Secundi, 1685, 64 vols. (London, 1767-1832), vol. 14, 102.

8 Church of England, A form of prayer and thanksgiving to Almighty God, for having made his highness the prince of Orange the glorious instrument of the great deliverance of this kingdom from Popery and arbitrary power (London, 1689).

9 Church of England, Additional prayers to be used together with those appointed in the service for the Fifth of November (London, 1689).

10 See David Cressy, Bonfires and bells. National memory and the Protestant calendar in Elizabethan and Stuart England (London: Weidenfeld \& Nicolson, 1989), 185-186; James Caudle, Measures of allegiance. Sermon culture and the creation of a public discourse of obedience and resistance in Georgian Britain, 1714-6o, PhD thesis, Yale University (1995), 255-258; James R.R. McConnel, 'The 1688 landing of William of Orange at Torbay: mumerical dates and temporal understanding in early modern England', The Journal of Modern History 84 (2012), 539-571, there 547.

11 Kai Nürnberger, Die Kunst der Information. König Wilhelm III. und die Medien seiner Zeit, Britannica et Americana 3/21 (Heidelberg: Winter, 2003); Craig Rose, England in the 169os. Revolution, Religion and War, A history of early modern England (Oxford: Blackwell, 1999), 18-62.

12 This range of discourse was also reflected in the funeral sermons delivered after King William's death in 1702; cf. Ulrich Niggemann, 'Divine right, 'courtly reformation' 
of what was acceptable, these languages and media helped to compose a canonical narrative of events. William's 'Declaration of Reasons' as well as the resolution of the Convention or the 'Declaration of Rights' became central texts for the defenders of the Revolution, referred to in a large variety of political pamphlets and sermons.

However, the state seems to have remained quite tolerant of ambiguity. Even with regard to preaching on the thanksgiving days, there was remarkable latitude for preachers to speak about the Revolution. ${ }^{13}$ It seems that the government offered only patterns, which could be used for a wide range of utterances concerning the Revolution.

Undesirable interpretations were nonetheless suppressed. This suppression applied not only to Jacobite pamphlets but also to a 'Pastoral Letter' by Bishop Burnet, who was well known as a supporter of the government. Burnet had argued that William's coming to the throne was the result of a successful conquest, and obedience was due to him because he was king de facto.${ }^{14}$ Strikingly, it was not the court, but Parliament, which ordered the book to be burnt by the common hangman. ${ }^{15}$ Despite such spectacular acts of suppression, a wide range of interpretations was possible, and various versions of the memory of the Revolution were allowed to be circulated. The expiration of the Licensing Act in 1695 further widened the opportunity to speak about the Revolution in various ways. ${ }^{16}$

\section{Pressure Groups, Factions, Parties}

This relative tolerance concerning differing interpretations of the Revolution allowed room for contention. Different groups and parties began

or contractarianism? Political and theological languages in the funeral sermons on King William III', Barok 18 (2011), 115-127.

13 With regard to the Hanoverian period cf. Caudle, Measures, 205-211. Generally for such observations, Kevin Sharpe, Selling the Tudor monarchy. Authority and image in sixteenth-century England (New Haven, Conn.: Yale University Press, 2009), 5-34.

14 Gilbert Burnet, A pastoral letter writ by the right reverend father in God Gilbert, lord bishop of Sarum, to the clergy of his diocess, London 1689; William Sherlock, the case of allegiance due to soveraign powers, stated and resolved, according to scripture and reason, and the principles of the Church of England (London, 1691).

15 Mark Goldie, "The Revolution of 1689 and the structure of political argument. An essay and an annotated bibliography of pamphlets in the Allegiance Controversy', Bulletin of Research in the Humanities 83 (1980), 473-564, there 515-517; John P. Kenyon, Revolution principles. The politics of party, 1689-1720 (Cambridge: Cambridge University Press, 1977), 31.

16 Cf. Karl T. Winkler, Handwerk und Markt. Druckerhandwerk, Vertriebswesen und Tagesschrifttum in London 1695-1750 (Stuttgart: Steiner, 1993), 35. 
to develop rival interpretations of the Revolution. As early as the Convention, much of the discussion was dedicated to the question of how to interpret the situation caused by William's invasion and James' flight. In the end, the discussion centred on the word 'abdication', which could mean a voluntary resignation as well as a forced deposition. ${ }^{17}$

In the first phase of the 'memory war', beginning during the negotiations of the Convention, the front line, however, was mainly between those approving of the Revolution and the Settlement, and those rejecting it. The battle intensified in the so-called 'Allegiance Controversy' after the introduction of the new oath of allegiance when some of the bishops and many of the lower clergy refused to take the oath. These nonjurors became bitter enemies of the new regime and publicly denied its legitimacy. ${ }^{18}$

At the same time, the official view of the Convention left room for a variety of interpretations. As Mark Goldie has demonstrated, there was indeed a wide range of arguments defending the Revolution, from radical contract theories to divine right of providence or a conquest by William. ${ }^{19}$ This variety points clearly to the ideological differences below the surface of the consensus reached by the Convention. During the first few years after the Revolution, however, these differences seemed less important than the defence and justification of the events of 1688-89.

It is striking that most of the early accounts of the reign of James II were more or less composed along the lines given in the 'Declaration of Reasons' and the 'Declaration of Rights'. Key elements, for example, included James' fair promises in the beginning of his reign, his 'pulling off the mask' by introducing Roman Catholic mass, the 'Bloody Assizes' after the rebellion of the duke of Monmouth, the introduction of an Ecclesiastical Commission and the suspension of the Bishop of London, the keeping of a standing army, the prosecution against the Seven Bishops and, as a climax, the illegitimate birth of a Prince of Wales. The story was composed not only alongside the 'Declaration', but also followed narratological patterns that make for a good story. ${ }^{20}$ It begins with a fair prospect of harmony, followed by the first signs of a conflict, which was then developed to a

17 Cf. Kenyon, Revolution principles, 5-20; Thomas P. Slaughter, “"Abdicate” and "contract” in the Glorious Revolution', The Historical Journal 24 (1981), 323-337.

18 William Gibson, The Church of England, 1688-1832. Unity and accord (London: Routledge, 2001), 35-40; Rose, England, 152-160.

19 Goldie, 'The Revolution of 1689', 486-489. See also Kenyon, Revolution principles, 21-6o.

20 Monika Fludernik, Erzähltheorie. Eine Einführung, (3rd ed., Darmstadt: Wissenschaftliche Buchgesellschaft, 2010). 
climax, after which the downfall began. As part of this downfall and change for the better came William's preparations. The storm, driving back the invasion force, as well as James' last-minute attempt to reverse some of his measures worked as obstacles delaying the hoped-for result and providing suspense. The bloodless march of William towards London and the collapse of James' army, however, were recounted in most accounts as the last steps to the happy ending of James' flight and William and Mary's coronation. ${ }^{21}$

Of course, interpretations of James' intentions, his flight to France and the character of the Revolution as a whole differed. The mainstream of memorial texts depicted William as England's providential deliverer, and this was also the official version presented, for example, in the Forms of Prayer for the services of thanksgiving on 31 January, 14 February and 5 November. ${ }^{22}$ The people of England had a quite passive role in these accounts. James' flight to France was interpreted in many accounts of the Revolution as a voluntary desertion, abdication or resignation, leaving the throne vacant for William. ${ }^{23} \mathrm{~A}$ few accounts differed from this version. Samuel Johnson, for example, accused the authors of such stories of being liars, whose stories served to keep up the passive obedience doctrine of the Anglican clergy, which condemned every form of resistance, even against tyrants. ${ }^{24}$ In Johnson's version, James was driven out of the country by the people aided by William. For him the people had a right to defend themselves against tyranny and oppression. ${ }^{25}$ For others, William

21 Just a few examples out of many: Guy Miège, The new state of England under their majesties K. William and Q. Mary, (2nd ed., London, 1694); John Seller, History of England. Giving a true and impartial account of the most considerable transactions in church and state, in peace and war, during the reigns of all the kings and queens, from the coming of Julius Caesar into Britain (London, 1696), 638-655; Abel Boyer, The history of King William the Third, 3 vols. (London 1702-1703), vol. 2.

22 For the image of William cf. Rose, England, 18-62; Nürnberger, Kunst; Ulrich Niggemann, 'Der mediale Umgang mit dem Tod eines umstrittenen Herrschers. Die Memoria Wilhelms III. zwischen 'Glorious Revolution' und Hannoverscher Thronfolge', in Christine Roll, Frank Pohle and Matthias Myrczek (eds.), Grenzen und Grenzüberschreitungen. Bilanz und Perspektiven der Frühneuzeitforschung, Frühneuzeit-Impulse (Cologne, Vienna, Weimar: Böhlau, 2010), vol. 1, 299-312.

23 E.g. [Edmund Bohun], The history of the desertion, or an account of all the publick affairs in England, from the beginning of September 1688 to the twelfth of February following (London, 1689), 0,153.

24 Samuel Johnson, An argument proving, that the abrogation of King James by the people of England from the regal throne, and the promotion of the prince of Orange, one of the royal family, to the throne of the kingdom in his stead, was according to the constitution of the English government, and prescribed by it (London, 1692), 11.

25 Ibid., 11-12, 16, 33-35. 
was a victor in a just war between two sovereign princes. James' throne came into William's possession because William had conquered James in battle. ${ }^{26}$

It is obvious, therefore, that different memories and different narratives of the Revolution were in play and that the consensus reached in the Convention was fragile. However, the breakup of consensus and the beginning of a 'memory war' within the camp of the supporters of the Revolution became obvious only towards the end of William's reign and during the reign of Anne. The sharp conflict among different groups approving of the Revolution marks a second phase of the 'memory war', which reached its climax during the pamphlet war between Benjamin Hoadly, Francis Atterbury and Offspring Blackall as well as in the course of the Sacheverell affair.

The controversy over memories of the Revolution had its origin in the conflicts within the Church of England about the Church's relationship to King and State. One of the main tenets of the High Church party within the Anglican Church was its doctrine of passive obedience and non-resistance, a doctrine driven by a nostalgic view of the Laudian and Caroline Church and by the condemnation of the regicide of 1649 . 30 January, the commemoration day of the beheading of Charles I, was the central day of fasting and prayer for the High Church. This day was used for zealous preaching against those doctrines which seemed to justify resistance and regicide. ${ }^{27}$

Although Low Church clerics were normally not radical asserters of resistance theories, they admitted that resistance in extreme cases could be justified. And although they might be readier than their High Church counterparts to submit the Church to the State, they at the same time were more open to toleration of Dissent and to a more relativistic view of State and Church. For them, Church and State were not universal and untouchable powers but institutions liable to human reason. Thus, doctrines of parliamentary sovereignty and right of resistance in the people were accepted by most Low Church clerics. ${ }^{28}$

The sermons by Offspring Blackall from 1705 onwards stressed the 'subject's duty' to submit to earthly governments and were strong confirmations

26 E.g. Burnet, Pastoral letter.

27 Caudle, Measures, 240-247. Generally for High Church doctrines Gareth V. Bennett, The Tory crisis in church and state, 1688-1730. The career of Francis Atterbury bishop of Rochester (Oxford: Clarendon Press, 1975).

28 Overview by Gibson, Church of England, 70-86. 
of the doctrines of passive obedience and non-resistance. ${ }^{29}$ On the opposite side, Benjamin Hoadly, a Low Church cleric and Whig, derived Queen Anne's right to the throne solely from the Revolution and the Protestant Succession established by King William..$^{30}$ For him, the Revolution was founded upon resistance, and this resistance had saved England 'from utter ruine'. ${ }^{31}$ In a spectacularly new interpretation of St Paul's thirteenth letter to the Romans, he stated that obedience is due only to rulers acting for the common good. ${ }^{32}$ It was this interpretation of St Paul that Francis Atterbury sharply attacked, arguing that Hoadly's doctrine of resistance was essentially popish because it was first used by Jesuits in the sixteenth century and could be held responsible for the English Civil Wars of the 1640 s. $^{33}$

Thus, we have two lines of argument, one stressing resistance and the other stressing non-resistance, but both attempting to justify the Revolution. The same pattern of argument can be observed in the Sacheverell crisis. Henry Sacheverell, a parish priest in Southwark, in his sermon on 5 November 1709, fiercely attacked the Low Church clerics, accusing them of propagating rebellious doctrines and undermining the foundations of the Church of England. ${ }^{34}$ The Whigs, in contrast, argued that the Revolution could be defended only by resistance theories.

In the course of these struggles over the memory of the Revolution, the canonical narrative established in the early years of King William's rule became brittle. William's bloodless victory, for example, was now questioned not only by Jacobites but also by Whig writers. Hoadly, for

29 Offspring Blackall, The subjects duty. A sermon preach'd at the parish-church of St. Dunstans in the West, on Thursday, March the 8th 1704/5 (London, 1705).

30 Benjamin Hoadly, A sermon preach'd on the eighth of March, 1704-5. Being the anniversary day of Thanksgiving for the queen's accession to the crown (London, 1705). For the life and work of Benjamin Hoadly see William Gibson, Enlightenment prelate. Benjamin Hoadly, 1676-1761 (Cambridge: Clarke, 2004); Stephen Taylor, 'Benjamin Hoadly', in The Oxford Dictionary of National Biography, 6o vols. (Oxford: Oxford University Press, 2004), vol. $27,340-348$.

31 Benjamin Hoadly, The measures of submission to the civil magistrate consider'd. In a defence of the doctrine deliver'd in a sermon preach'd before the rt.hon. the lord mayor, aldermen, and citizens of London, Sept. 29, 1705 (London, 1706), 70-71, 79-83.

32 Benjamin Hoadly, A sermon preach'd before the right honourable the lord mayor, and aldermen, livery-men, of the several companies of London (London, 1705).

33 Francis Atterbury, An enquiry into the nature of the liberty of the subject, and of subjection to the supreme powers (London, 1706). For Atterbury see Bennett, Tory crisis.

34 Henry Sacheverell, The perils of false brethren, both in church, and state. Set forth in a sermon preach'd before the right honourable the lord-mayor, aldermen, and citizens of London, at the cathedral-church of St. Paul, on the 5th of November, 1709 (London, 1709); Geoffrey Holmes, The trial of doctor Sacheverell (London: Eyre Methuen, 1973). 
instance, stated with regard to the doctrine of the right of resistance that the Revolution was 'begun upon the foundation of this doctrine', and one of his defenders asserted: 'Now 'twas resistance which brought about the late happy Revolution'. ${ }^{35}$ In that context, even battles and skirmishes in the course of William's march towards London were mentioned as arguments against the non-resistance doctrine. ${ }^{36}$

Another example of the shift of argument concerns the birth of James' son. Whereas Jacobites had stressed his legitimacy from the beginning, ${ }^{37}$ the consensual view was that he was an 'imposture', who had not been borne by the Queen but had been smuggled into the Queen's bedchamber to perpetuate Catholic rule in England. Therefore, James Francis Edward could not have any claims to the throne of his abdicated father. In contrast to this view, Daniel Defoe, for example, stressed in 1705, 'that the true divine right of the crown, is in the person of King James III, as they count him'. ${ }^{38}$ The following year Robert Fleming stated that Queen Anne's title to the crown could not be contested, 'even upon the supposition, that they could prove the legitimacy of the birth of a certain Prince'. ${ }^{39}$ The main line of argument against the 'Pretender', for these authors, was not his illegitimacy but his being educated in French and 'popish' principles. ${ }^{40}$

For these changes of strategy, one can cite at least two obvious reasons. The first is that, even if the coronation of William and Mary as well as that of Anne could be represented as maintaining hereditary monarchy, the succession of the House of Hanover caused difficulties because at least some authors denied the hereditary right of the Elector. ${ }^{41}$ Divine hereditary right, therefore, was a weak foundation for the Protestant succession. To solve this problem, stress was laid on the sovereignty of the people

35 Hoadly, Measures, 83; Bess o'Bedlam's love to her brother Tom: with a word in behalf of poor brother Ben Hoadly (London, 1709), 12.

36 E.g. John Dunton, The bull-baiting: or, Sach-ll dress'd up in fire-works. Lately brought over from the Bear-Garden in Southwark; and expos'd for the diversion of the citizens of London, at six pence a-piece (London, 1709), 17.

37 Cf. e.g. [Charles Leslie], Remarks on some late sermons; and in particular on Dr. Sherlock's sermon at the Temple, Decemb. 30.1694. In a letter to a friend (2nd ed. London, 1695), 29.

38 Daniel Defoe, Review of the affairs of France, no. 82, 11 September 1705, ed. John McVeagh (London: Pickering \& Chatto, 2004), vol. 2, 580.

39 Robert Fleming, Seculum Davidicum redivivum; or, the Divine right of the revolution evinc'd and apply'd: in a discourse, occasion'd by the late glorious victory at Ramilly (London, 1706), 25 .

40 Reasons against receiving the pretender, and restoring the Popish line (London, 1710), 4; Fleming, Seculum, 39; Defoe, Review, no. 79, 4 September 1705, 563; Reasons prov'd to be unreasonable: or, an answer to the reasons against a war with France (London, 1702), 10-11.

41 Very strongly put forward by the anonymous author of Reasons against receiving, 10. 
and the right of Parliament to alter the succession, if necessary to avoid tyranny. Daniel Defoe, again, pointed out, 'that parliamentary authority has a superior right to that of primogeniture or inheritance, and can, and may lawfully limit succession'. ${ }^{42}$

The second reason is that the right of resistance became a central theme for Whigs as well as Low Church clerics. By focusing on that theme, they could not only challenge the established narrative but also attack their Tory and High Church counterparts. That means that the targets of their attacks were no longer the nonjurors and Jacobites but their opponents within the Revolution camp, who still maintained that the 'Pretender' was an 'imposture' and that the Revolution had been brought about by James' abdication without any relevant changes in the constitution.

Thus, opposing groups used the memory of the Revolution to stress their political doctrines-non-resistance and passive obedience, on the one hand, parliamentary sovereignty and resistance against tyranny, on the other. Remarkably, both parties insisted that they approved of the Revolution. The 'memory war' about the 'Glorious Revolution' during the reign of Anne, therefore, was not about whether the Revolution could be justified or not but about its meaning and the ways of justifying it. There were competing interpretations of the Revolution already established in the early years of William and Mary and leading to deep divisions during the reign of Anne. The anniversaries and services of thanksgiving provided by the state were used by opposing groups who attempted to implement their interpretation of the event. By this means, they tried to shape memories according to their political doctrines.

\section{The Use of Memory}

In this struggle between the church parties and their political equivalents, both sides attempted to sharpen their positions and their political identities. Even more important, they also tried to position themselves as the best and most loyal asserters of the Revolution. Both sides were keen to accuse their adversaries of 'blackening' the Revolution. From the point of view of Whiggish authors, Blackall, Atterbury and Sacheverell had tried to condemn the Revolution by rejecting resistance and maintaining Divine Right. ${ }^{43}$ An anonymous author wrote, 'that by upholding the doctrine of

42 Defoe, Review, no. 82, 11 September 1705, 580.

43 E.g. Hoadly, Measures, 20. 
passive obedience to the will of a prince, he [Blackall] might cast a slur upon the justice of the late happy Revolution, and make void the principle upon which it was grounded'.44 Other writers accused their adversaries of 'making the late Revolution a damnable rebellion and usurpation' and of 'blacken[ing] all the glorious instruments of our deliverance'. ${ }^{45}$ Benjamin Hoadly, in an 'Election dialogue' in 1710, used the argument against the Tories: 'You will see who they are that revile, and lessen your glorious deliverer, and glorious deliverance'. ${ }^{46}$

Tory and High Church authors, however, denied that they had any intention of vilifying the Revolution. On the contrary, they accused the Whigs of casting odium on the Revolution by their attempts to justify it through their doctrine of resistance. It was not only the known Jacobite Charles Leslie who accused Whig authors of 'blackening and aspersing' the Revolution, 'by making it coercion and consequently rebellion' ${ }^{47}$ Atterbury also denied that he or Blackall had ever rejected the Revolution. They had only tried to cleanse it of any association with unlawful rebellion. The anonymous pamphlet The Revolution no Rebellion makes this point very clearly: The Revolution, the author argued, cannot be derived from any resistance by the people but only from the abdication of King James. James had not been deprived by reason of his mal-administration, but he himself had voluntarily resigned his throne and left the government in a state of anarchy. On these grounds, the Convention had offered the Crown to the next heirs. ${ }^{48}$

The same arguments were applied in the Sacheverell affair. The Whigs condemned Sacheverell's sermon as an attack against the Revolution. By condemning resistance, they argued, Sacheverell and others rejected the Revolution as utterly illegal. ${ }^{49}$ Even in the 'Articles of impeachment'

44 Bess o'Bedlam's love, 6.

45 Vox populi, vox Dei: being the true maxims of government (London, 1709), 26-27; Samuel Johnson, An answer to the history of passive obedience, just now reprinted under the title of A defence of Dr. Sacheverell (London, 1710), 1.

46 [Benjamin Hoadly], The election-dialogue, between a gentleman, and his neighbour in the country, concerning the choice of good members for the next parliament (London, 1710), 8-9.

47 [Charles Leslie], 'The rehearsal, No 9', in A view of the times, their principles and practices. In the fourth volume of the rehearsals (London, 1709), unpag.

48 The revolution no rebellion; or, serious reflections offered to the reverend Mr. Benjamin Hoadly, occasion'd by his considerations on the bishop of Exeter's sermon (London, 1709).

49 Chuse which you please: or, Dr. Sacheverell, and Mr. Hoadly, drawn to life (London, 1710); An appeal from the city to the country, for the preservation of her majesty's person, liberty, property and the protestant religion (London, 1710); [John Toland], Mr. Toland's reflections on Dr. Sacheverells sermon preach'd at St. Paul's, Nov. 5, 1709 (London, 1710). 
against Henry Sacheverell, the preacher was charged with denouncing the Revolution. ${ }^{50}$ Sacheverell, however, denied any intention to condemn the Revolution. On the contrary, during the impeachment launched against him in the House of Commons by the Whigs, he insisted that his intention had been 'to clear the Revolution and His Late Majesty, from the black and odious colours which their greatest enemies had endeavoured to cast upon both'. ${ }^{51}$

For Tory and High Church authors, non-resistance was an indispensable part of their political creed and identity. Therefore, it was of vital importance for them to distinguish between the Revolution, which was brought about without any resistance and coercion against the King, and the Rebellion of the 1640s, which was unlawful and had ended in regicide. $^{52}$ The allegation, therefore, that the Whigs by justifying resistance in the Revolution also legitimised the Rebellion and Civil War of the midcentury, played a central role in Tory propaganda. Even in popular ballads and poems, the accusation against the Whigs was: 'Again they play the Game of Forty One'. ${ }^{33}$ Thus, Whigs were accused by their Tory counterparts of being republicans, whereas the Whigs charged the Tories with being Jacobites.

\section{Conclusion}

The controversies over the memory of the 'Glorious Revolution' did not end in 1714 when Georg Ludwig of Hanover, as George I, ascended the throne of Great Britain. It is not easy to say who at that time had won this 'memory war' although it may be tempting to say that the long period of one-party government by the Whigs could at least partly be explained by their successful 'self-fashioning' as the real asserters of the Revolution, whereas the Tories were suspected of being disloyal to the Revolution settlement. At the end of Queen Anne's reign, at least two positive versions of a narrative about the Revolution existed. In terms of composition and narrative patterns, they were quite similar and thus strengthened the canonical elements of the narrative. But they differed in many points of

50 The answer of Henry Sacheverell D.D. to the Articles of Impeachment, exhibited against him by the honourable House of Commons etc. (s.l., 1710), 5.

51 Ibid., 9.

52 The revolution no rebellion.

53 A collection of poems, for and against Dr. Sacheverell (London, 1710), 3. 
interpretation and referred to different value systems and political creeds. However, two important results of the struggle over memory during the reign of Anne can be named:

1.) One main result was the development of distinct party identities, which were often simplified and popularised in printed dialogues and comparisons. The two political and church parties could now be identified by sets of ideological statements, which allowed a broader public to position the actors in the political landscape. For both parties the Revolution was a common point of reference, and both parties had to develop their political creeds with regard to the Revolution. But they could easily be identified by their associating the Revolution either with resistance or with the idea of a voluntary abdication of King James.

2.) However, what at first sight seemed to have deepened the ditches between opposing groups and to have heightened ideological antagonisms, in fact contributed greatly to the 'growth of political stability'. ${ }^{54}$ Because the two most important political currents in post-revolutionary England attempted to build up their political identities on the Revolution, they, thereby, accepted the Revolution Settlement and propagated it to different target groups, some of which could be suspected to be potentially hostile to the Revolution. The differing opinions, in spite of their harsh confrontation, had a common point of reference, which became normative in the course of the debates. That does not mean that there was universal, whole-hearted acceptance of the Revolution, but by the repeated utterances in favour of the Revolution, it became more and more difficult to ignore the dominant discourse. By the end of the century, especially during the centenary celebrations of the Revolution in 1788, it became clear that the 'Glorious Revolution' had become a canonical episode in the national memory and an important part of British national identity. ${ }^{55}$

\footnotetext{
54 Term by John H. Plumb, The growth of political stability in England, 1675-1725, reprint (London: Macmillan, 1982).

55 For the 1788 celebrations see Lois G. Schwoerer, 'Celebrating the Glorious Revolution, 1689-1989', Albion 22 (1990), 1-20; Kathleen Wilson, 'Inventing revolution. 1688 and eighteenth-century popular politics', The Journal of British Studies 28 (1989), 349-386.
} 
Erika Kuijpers, Judith Pollmann, Johannes Müller, and Jasper van der Steen - 978-90-04-26125-9 Downloaded from Brill.com04/26/2023 11:57:20AM via free access 


\title{
CIVIC AND CONFESSIONAL MEMORY IN CONFLICT. AUGSBURG IN THE SIXTEENTH CENTURY
}

\author{
Sean F. Dunwoody
}

In the summer of 1584 , an uprising over a reform of the calendar in the city of Augsburg occasioned a struggle to define both the memory of the debates that had precipitated the uprising and the memory of what the uprising was about. In Augsburg, the magistracy adopted the reformed Gregorian calendar against the will of an increasingly organised oppositional Protestant group formed around the Protestant ministers, the municipal church warden, and members of the municipal elite. In debates and legal suits prior to the adoption of the reformed calendar and in the aftermath of the introduction of the reform, the two sides pursued divergent strategies of framing the events. On the one side, the magistracy cultivated a memory of the debates and of the uprising as one of politico-legal authority challenged; and it sought to demonstrate its authority over public spaces within the city and its authority as an imperial estate within the structures of the Holy Roman Empire. On the other side, the oppositional Protestant group cultivated a memory of the events within the frame of the soteriological story of Christian persecution, martyrdom, and constancy.

Such divergent strategies of cultivating memory are not surprising in an age of confessionalizing cultures. What is remarkable, however, is the fact that these divergent strategies were cultivated within a single community, and centring on an event that nearly upended all civil life, and yet did not lead to further conflicts. On the contrary, the two memories coexisted within a community that managed to keep the peace even in an age of growing confessional-political tensions in the wider Empire. What is surprising about Augsburg is thus not only the degree to which this community showed itself capable of generating divergent memories of a contentious moment in the city's history, but the degree to which Augsburg's citizens were capable of accommodating them.

How was it possible for some Augsburgers to cultivate a memory centred around their identity as members of a persecuted faith groaning 
under the tyranny of magisterial authority, while simultaneously embracing their place within the civic elite of the city? Though this essay cannot answer this question fully, it can help us better appreciate the degree to which the Reformation gave rise to a new world in which particularistic, confessionalised memories and identities could be crafted that were at odds with municipal or official memories and identities. The way in which these two memories were simultaneously accommodated in Augsburg reveals something of the ways in which this city, unlike so many similar communities in early modern Europe, remained largely at peace in the face of confessional diversity. ${ }^{1}$ In this essay, I will explore the divergent strategies used to construct competing memories of the events surrounding the introduction of the Gregorian calendar in Augsburg and suggest how these strategies underlined divergent conceptualisations of community in the wake of the Reformation. I argue that divergent memories were grounded on divergent foundations: the accusatory writings of the oppositional Protestant group, especially in the person of Augsburg's former superintendent of the Protestant churches in Augsburg, Georg Müller, were rooted in their claims to probity as preachers of the Word, as exemplified in their use of biblical references drawing parallels with the present. By contrast, the exculpatory publications of the council highlighted juridical procedures rooted in imperial traditions and constitutional prerogative in order to emphasise the legality of its actions. As such, these two justifications underline the degree to which political and confessional unity could be split in the wake of the Reformation.

Similarly, each side sought to articulate the space of its memory in its own particular way. Müller and his party crafted their narrative clandestinely in the city, through missives sent by an exiled minister to his congregants left behind in Augsburg. The magistracy, through its main spokesman, the city syndic Georg Tradel, ${ }^{2}$ asserted its power to craft the official memory of events by proclaiming its narrative in the council house and in the public squares of the city. Each side mobilised publishing networks that underlined confessional allegiance, on the one hand, and traditional municipal authority, on the other.

A religiously pluralist imperial city is an especially useful context in which to think about this development for several reasons. First, in the

\footnotetext{
1 I explore this process of peace more fully in my dissertation, 'Conflict, confession, and peaceful coexistence', PhD diss., University of Chicago (2012).

2 Gernot Ludwig, 'Dr. Georg Tradel, ein evangelischer Jurist aus Dillingen', Jahrbuch des Historischen Vereins Dillingen an der Donau 90 (1988), 326-340.
} 
absence of princely superioritas, imperial cities are arguably the most extreme case of fractured authority in the early modern world. The radical diversity of early modern authority structures could be read on the cityscape of any early modern imperial city, and this was most certainly the case in Augsburg. Second, the religiously pluralist society of a city like Augsburg forced explicit, critical re-examination of the foundations of the commonwealth in a way that was usually only latent in pre-Reformation imperial cities or in cities where only one faith was legally sanctioned and tolerated. In some parts of contemporary Europe, religious conflict, once overcome, was supposed to be 'forgotten' and painful memories of the past cast into oblivion. ${ }^{3}$ On the other hand, in confessionally uniform Protestant cities and principalities, confessional identity prompted historically minded authors to rewrite memories of the past and of recent tribulations as trials of the righteous at the culmination of history. 4

In a city like Augsburg, however, neither of these things was entirely possible. As we shall see, magisterial attempts to impose a 'forgetting' of injuries suffered proved unsuccessful. At the same time, confessional pluralism prevented the emergence of an officially sanctioned confessionalised memory of the events. In the place of these two alternatives-far more familiar to scholars of religious conflicts in early modern Europe-stood a third: a reconsideration of the place and limits of political authority and civic life, on the one hand, and of religion and confessional particularism, on the other. Competing memories in Augsburg of the Calendar Controversy and of the events of 4 June 1584 and the way in which this particular 'memory war' was resolved offer insights into Augsburg's peculiar success at maintaining religious peace in an age of religious war.

That the traditional Julian calendar was in need of correction was not the discovery of Europeans in the Age of the Reformation. For centuries, scholars had sought to offer a way of realigning the civil calendar with the astronomical realities, an incongruity that had led to calendrical Easter

3 See, for instance, Philip Benedict, 'Divided memories? Historical calendars, commemorative processions and the recollection of the Wars of Religion during the Ancien Regime,' French History 22 (2008), 381-405.

4 D.M. Loades (ed.), John Foxe and the English Reformation, St. Andrews studies in Reformation history (Aldershot and Brookfield, VT: Scolar Press, 1997); Gregory B. Lyon, 'Baudouin, Flavius, and the plan for the Magdeburg Centuries', Journal of the History of Ideas 64, no. 2 (2003), 253-272. 
slipping ever further back into astronomical winter. ${ }^{5}$ By 1582, the calendric vernal equinox fell on 11 March, ten days earlier than the astronomical equinox. The solution-one that was ultimately sanctioned by the Catholic Church-called for skipping ten days on the calendar. Accordingly, on 24 February 1582, Pope Gregory XIII decreed the implementation of the reform in the night of $4-5$ October 1582 (so that the next day was reckoned as 15 October). The papal bull in which the decree was included, Inter gravissimas, threatened excommunication as the penalty for all who failed to institute the reform. At first, the new calendar was implemented only in the Papal States; but the Papacy invested considerable efforts in seeing that it was adopted everywhere.

Recognition of the calendar's inaccuracies was ecumenical, but because the change was ordered by the pope, to many Protestants throughout Europe, the new calendar came to be considered anathema. Adoption might insinuate papal authority in Protestant territories; it could imply papal authority over civil and their derivative liturgical calendars. In a short time, this inchoate sentiment had started to evolve into a unified, theological opposition.

The city of Augsburg was in a particularly difficult position. Inhabited by both Protestants and Catholics and surrounded by Catholic powers already committed to the new calendar, the Augsburg magistracy necessarily had to apply a more complicated calculus. Some of Augsburg's Protestants feared that the calendar reform might be a first step towards a papal take-over of the city; petitions were sent to the city council by the

5 On the history of the calendar, the recognition of its defects, and of efforts to reform it, see Gregorian reform of the calendar. Proceedings of the Vatican Conference to commemorate its 4ooth anniversary, 1582-1982, ed. George V. Coyne, Michael A. Hoskin, and Olaf Pedersen (Vatican City: Pontifica Academia Scientiarum, Specola Vaticana, 1983). For a more specific review of the situation in Germany, see Felix Stieve, 'Der Kalenderstreit des 16. Jahrhunderts in Deutschland', Abhandlungen der historischen Classe des königlich Bayerischen Akademie der Wissenschaften 15, no. 3 (1880), 1-99. See also Dirk Steinmetz, Die Gregorianische Kalenderreform von 1582. Korrektur der christlichen Zeitrechnung in der frühen Neuzeit (Oftersheim: Steinmetz, 2011), esp. 46-72. The following survey of events is indebted to Paul Warmbrunn, Zwei Konfessionen in einer Stadt. Das Zusammenleben von Katholiken und Protestanten in den paritätischen Reichsstädten Augsburg, Biberach, Ravensburg und Dinkelsbühl von 1548 bis 1648 (Wiesbaden: F. Steiner, 1983), esp. 359-375; Eberhard Naujoks, 'Vorstufen der Parität in der Verfassungsgeschichte der schwäbischen Städte (1555-1648). Das Beispiel Augsburg', in Jürgen Sydow (ed.), Bürgerschaft und Kirche (Sigmaringen: Thorbecke, 1980), 38-66; and especially Bernd Roeck, Eine Stadt in Krieg und Frieden. Studien zur Geschichte der Reichsstadt Augsburg zwischen Kalenderstreit und Parität, 2 vols. (Göttingen: Vandenhoeck \& Ruprecht, 1989), vol. 1, esp. 125-137. 
Protestant church wardens voicing their opposition. ${ }^{6}$ They even submitted a petition to the Imperial Chamber Court to force the council to stay any decision. By contrast, the majority of the politically active citizenrythe confessionally mixed patriciate and the largely Protestant merchant elite-focused on Augsburg's economic fate, fearing the consequences were the city to be left ten days behind its neighbouring territories. ${ }^{7}$ Both quotidian provisioning of the city and the annual trading cycles of the longdistance merchants would be subject to considerable inconveniences. ${ }^{8}$ In the end, the council_-Protestants and Catholics alike-decided to implement the new calendar against the protests of Protestant theologians in other territories, initially only in 'court, council, and market days' to satisfy a stay issued by the Chamber Court. ${ }^{9}$ Though the council had won support from a (mostly Protestant) Diet of Cities in 1583, it soon faced an oppositional group in Augsburg that railed against the new calendar. This group - which grew and coalesced around the lay Protestant church wardens, the ministers, and especially Georg Müller-not only voiced their opposition from the pulpit but also continued their case before the Chamber Court. Meanwhile, within the city, each side disputed the legitimacy of the other's claim to speak with authority in the matter. ${ }^{10}$ What had begun as a relatively unexciting question of ensuring the relative correspondence of civil and church calendars with astronomical realities had

6 Stadtarchiv Augsburg (hereafter: StadtAA), Reichsstadt (hereafter: RS), Rat, Ratsprotokolle, ad 1583 January 15 , f. 5 r.

7 For a reading that emphasises the confessional aspect of the conflict from the perspective of a key contemporary's correspondence, see Regina Dauser, Informationskultur und Beziehungswissen. Das Korrespondenznetz Hans Fuggers (1531-1598) (Tübingen: Niemeyer, 2008), 251-283.

8 Dauser, Informationskultur, 258, though Dauser implies that the council's decision was driven far more by confessional considerations than mercantile ones. In this, she follows the interpretation of Warmbrunn, Zwei Konfessionen. By contrast, Roeck's interpretation centres on commerce: Eine Stadt, vol. 1, 125. Roeck's arguments, taken together with Naujoks' foregrounding of confessional and economic grievances ('Vorstufen'), can be taken as an indication of the complexity of the events beyond a simply confessional mindset.

9 StadtAA, Rat, Ratsprotokolle, ad 1583 January 5 , f. 3 r. See also the council justification in ibid., ad 1583 January 19, ff. $7 \mathrm{r}-8 \mathrm{r}$. See also StadtAA, RS, Geheimer Rat, Religionsakten, Serie B, Kalenderstreitsakten, vol. 6o, f. 16v; Tradel claims that two sitting mayors, Ulrich Walther, a Protestant patrician, and Andreas Harder, a Protestant merchant, approved the measure. Council decision regarding civil matters: see the council decision of 29 March 1583, StadtAA, RS, Rat, Ratsprotokolle, f. $24 \mathrm{~V}$.

10 See for instance the exchange between the theologians and jurists reproduced in Staats- und Stadtbibliothek Augsburg (hereafter: SStBibAugsburg), $2^{\circ}$ cod $\mathrm{H} 18$, 'Augspurgischer Calender-Streit von anno 83 bis 9o', ff. 52-68 and 69-92, respectively. 
become a question crucial to both the Protestant community in Augsburg and the civil magistrates.

In the following months, tensions between the two sides only grew. Both political authorities and religious authorities - and their respective supporters in the wider populace-perceived the other to be encroaching on their rights and authority. Though the council tried to maintain the distinction between enforcing the calendar reform in civil matters and allowing the Protestant churches to retain the old calendar in their liturgy, peace was not achieved in the community. The divergence between the two calendars created considerable problems in everyday life. For instance, the overwhelmingly Protestant butchers refused to slaughter their cattle at the end of Lent in 1584; according to their calendar, the traditional Lenten prohibition on eating meat had not yet been lifted. ${ }^{11}$ However, for the council a line was crossed when the leader of the Protestant activist front in Augsburg, Georg Müller, authored a text in support of the Protestants in Cologne. In the text, Müller claimed that a citizenry had the right to overthrow a council. ${ }^{12}$ The obvious implications for Augsburg were too dangerous to ignore. When the same Müller led his fellow ministers in a defiant public rejection of a new council order in May 1584 ordering the reform of the Protestant liturgical calendars, the council decided to take more drastic measures.

On 4 June 1584, the council attempted to quietly seize Müller from his home and banish him from the city. The plot was discovered and the reaction swift. Within hours an armed mob of several thousand had gathered in the city centre around the council house, where panicked authorities trapped inside feared an overthrow of the government. We should see in this mob of artisans not only an angry reaction to a single event but an expression of discontent about the loss of political standing by guildsmen since the 1540 . The decision to focus energies on the prominently public space of the council house and the square before it was therefore no coincidence.

In the end, the mob refrained from open assault on the authorities, but they were quieted only by the arrival of the remaining Protestant ministers, who persuaded the populace to return to their homes. Though spectacular, the event resulted in little real violence. However, the clearing of

11 StadtAA, RS, Rat, Ratsprotokolle, ad 1584 February 4, f. 7 v.

12 Georg Müller (Mylius), Christlicher Sendtbrieff an einen Ersamen Raht der... Reichßstadt Cölln... (Heidelberg, 1583). 
the council house square only signalled the shift of the struggle to new terrain: a new battle was already brewing over how to craft a memory of the events.

The council was the first to begin articulating its own version of events. From the start, the council's efforts at memory-making appealed to traditional understandings of political authority. On 14 June 1584, the council published a proclamation, issued throughout the city's marketplaces, in the city squares, and other key sites of public authority in the city. ${ }^{13}$ In doing so, the council reclaimed those civic spaces briefly claimed by the mob. As laid out in the council's proclamation, the uprising occurred on account of the lack of proper deference to the civic authorities, the failure to maintain civic fraternity and the privileging of particularistic, confessional identities at the expense of a shared municipal one. If plastering the city's public spaces with proclamations was done in support of the council's claim to political authority, the same concern for undivided political authority also figured prominently in the council's next move.

Two weeks after the uprising, once hotter heads had cooled somewhat and the council again felt itself in undisputed practical control of the city, the council pressured the preachers to issue a statement from their pulpits during their Sunday sermons. In this statement, the preachers were forced to voice their acceptance of the magistracy's version of the events and their causes. With only minor changes, the statement repeated the main claims of the council's first post-crisis proclamation. ${ }^{14}$ In forcing the ministers to read this proclamation from their pulpits before their congregations, the council sought to reassert the political subordination to civic authority of the ministers, who in the previous few years had preached in increasingly strident tones.

The third step in the council's crafting of its memory of the events was to ground them in an insistence upon the council's political and legal function within the frame of the Empire. Accordingly, the council commissioned the publication of several pamphlets that included large portions of the materials submitted to and issued by the Imperial Chamber Court, where the council's position was ultimately vindicated. ${ }^{15}$ Legal authority

13 'Berüff So ein E Raht der Statt Augspurg den 14. Junij Anno 1584. auff den Plätzen der Stat thün vnd publicieren lassen', in SStBibAugsburg, 4 Aug 1021, 'Ordnungen ...', vol. 1.

14 StadtAA, RS, Geheimer Rat, Religionsakten, vol. 58, ff. 85r-91r.

15 Publikation der Röm[ischen] Kai[serlichen] Maj[estät] zwischen der Oberkeit und den Kirchendienern Augsburgischer Konfession in der Stadt Augsburg ergangenen letzten Resolution, ([Augsburg], 1586). 
and the council's place within the traditional political structures of the Empire were used as a means of authenticating the narrative constructed by the council. These pamphlets did more than merely restate the council's legal and procedural justifications for an audience at home; it is clear that the council was now writing for a wider Imperial audience that was highly attuned to the events in Augsburg. These pamphlets also sought to undermine an emergent, confessionalised counter-narrative of the events. As a council pamphlet put it:

An honourable council knew that God the Almighty, the one true author, source, protector, and guardian of all lordly authority and just causes, would never abandon his ordered creation and right justice, but rather that he would in his own good time, against all improper abominations, ensure that truth shone through. To God is due the highest and most obedient thanks and praise, that he, in his grace, ensured that the council's righteousness shone through as brightly as the midday sun. ${ }^{16}$

At this point, the council appears sensitive to the fact that religious ideals stood at the heart of the conflict. Accordingly, the council claimed the standard of righteousness for itself. The divine order was invoked to underline the justice of the council's legal and jurisdictional claims. The Protestant activist front bore responsibility for the uprising and for the general distrust among the citizenry, according to this council portrayal, because it had failed to respect the council's divine authority and jurisdiction, and especially to acknowledge that this authority was imperially sanctioned and constitutionally prescribed.

This official effort to craft the memory of events did not go unchallenged for long. The same minister who had channelled the emergent confessionalised identity of Augsburg's Protestants from the city's pulpits, Georg Müller, now took up the pen to ensure that his former congregants' memory of the events was not determined by the council's position. Writing from his exile in Ulm, Müller offered a 'missive and letter of solace' (Send- und Trostbrief) as an immediate reply to the council's version of events. In his absence, Müller reminded Augsburgers of the righteousness of their religious purpose and counselled steadfastness in a time of troubles. The events of 4 June, and all that had happened since, were bound

16 Publication / dern in der Calender sach / am hochlöblichen Kayserlichen Camergericht zü Speyer / den 13. dem Alten / oder den 23. tag May dem Newen Calender nach / zurechnen / jetztlauffenden 1584. Jars / für einen E Raht der Statt Augspurg / vnd wider etliche desselben widerwertige / eröffneter Urteil, a copy of which can be found in Stadt- und Staatsbibliothek Augsburg, $4^{\circ}$ Aug 1021, Ordnungen ... vol. 1, document no. 2. 
up in an almost eschatological framework, all tied to his congregants' identity as steadfast Protestants. ${ }^{17}$

A version of this missive was soon published for an audience that Müller now understood to be interested in this oppositional Protestant memory of events. ${ }^{18}$ The meaning and memory of Augsburg's domestic dispute was now being fought out before the much larger audience of the Imperial political public. The themes that Müller employed in this pamphlet reflect an attempt to frame the events in Augsburg as a story of individual salvation in the context of iniquitous secular powers. Accordingly, Müller's story is framed around biblical analogies. Rather than searching for justification with references to legal rights and procedural measures taken in the Empire's various institutions, Müller looked to the story of Exodus. Here, in his portrayal, Augsburg's Protestants - that is, Augsburg's true Christians - suffer under the unjust rule of a magistracy that is obstinate against God, which will ultimately lead to its downfall:

And yet every day their hearts are emboldened to seize at the Lord their God, and just like Uzziah, the king of Judah, they usurp what does not belong to them but to the ministers, who have been consecrated. They do not do God honour by that. Rather, they will be punished and the Church shall remain in the good order meant for it by God. ${ }^{19}$

Müller's reference here is to the story in the Second Book of Chronicles, in which Uzziah, in his arrogance and immoderation, usurped the priestly right to burn incense for God. What Müller does not spell out, but references only obliquely, is the outcome of that biblical parable: Uzziah, in the moment of his usurpation, was struck by leprosy, forced to cede the reign to his son; he lived out his days in seclusion. For Müller's Augsburg audience, the moral of this story was unmistakable: whereas the council made every effort to justify itself with reference to a-confessional legal rights and super-confessional imperial institutions, Müller sees only Catholics on one side and Protestants on the other. For him, the council in

17 A Latin version of this letter, 'Dominis Georgij Mylij ex Ulm 29. Maij, ao: 84. Reuerendis \& doctis viris \& Dominis M: Martino Riegero \& alijs Ministris Augustam versus missae litterae' can be found in SStBibAugsburg, $2^{\circ}$ cod. Aug. 195, 'Acta Augustana d.i. Amtshandlungen und amtliche Correspondenz der Stadt Augsburg 1566-1745', vol. 2.

18 Send- und Trostbrief an die evangelische Bürgerschaft in Augsburg, da ihre Seelsorger zur Stadt ausgetrieben worden (Wittenberg: Matthäus Welack, 1586), included in Stadtund Staatsbibliothek Augsburg, $4^{\circ}$ Aug 1021, Ordnungen ... vol. 1 as document no. 5 .

19 Ibid. 
Augsburg - even though there were still many Protestants in high municipal offices-is only a 'Papist council'.

Later that year, Müller published a second, widely disseminated pamphlet with different themes, but an identical purpose. The events in Augsburg were an attempt at unjust usurpation of priestly authority on the part of the council; and the Augsburg Protestants' suffering was a reflection of the Gospel story of suffering and salvation. ${ }^{20}$ The Augsburgers' actions were not a question of legal subjecthood, but rather of moral responsibility and Christian duties. Müller then rather quickly moves from these abstract pastoral admonitions to an explicit framing of the Augsburg events of $1583^{-84}$ as a story concerning Christian duty in a divinely ordained plan: the suffering in this life is a part of attaining the Kingdom of God. It is the true believers who suffer; they are the ones that are hated, who are insulted. In fact, their suffering at the hands of iniquitous rulers is a mark, a proof of their faith.

It is unsurprising that the council in Augsburg rejected this soteriologically centred memory of the events of $1583-84$. Instead, the council and Tradel restated and elaborated the official municipal memory of events as a matter of procedural, legal, and constitutional propriety on the part of the council, challenged by a cabal of disobedient citizens. In the document the council commissioned and published in response to Müller's publication, entitled 'Truthful Rejoinder to the Infamous Libel', the approach was markedly different. ${ }^{21}$ Here, the matter was one of civil discord. Müller had sought to rend the commonwealth in two and, to an extent, the authors concede, he succeeded. Inasmuch as his readers believed his fantastical version of events-Tradel calls Müller's text a 'fiction' (gedicht) - the effect has been of discord and divisions. There is no trust or friendship (vertrawen oder Freündschafft) between the council and Augsburgers. ${ }^{22}$

20 Georg Mylius, Augsburgische Handel, so sich wegen der Religion und im währenden Kalenderstreit mit Georgen Müller zugetragen (Wittenberg, 1586).

21 Der Herren Pfleger vnd Gehaimen Rät des heyligen Reichsstatt Augspurg Warhaffter gegenbericht / der Augspurgischen Händel vnd gegründte widertreybung und D. Georg Müllers nechstuerschinen 1586. Jars in Truckh außgetrewten Famos gedichts (Augsburg: Valentin Schönigk, 1587). A copy of this can be found in StadtAA, RS, EWA 510, vol. 2. On the printer Schönig(k): Theodor Wohnhaas, s.v. 'Die Schönig', Archiv für Geschichte des Buchwesens 5 (1964), col. 1473-1484; Schönig was, like most of Augsburg's printers, a Protestant. In 1572/73, he became the city's official printer (Stadtdrucker).

22 'Wann aber sein Famoßschrifft nit nun die Personen der Oberkeit priuatim verletzt / sondern sein gedicht zü gemeiner Statt allhie jmmerwerender zerrüttung vnnd spaltung / vnnd zu anrichtung newen vngehorsams vnnd mißtrawens wider die Oberkeit / one mittel gereichte... wa in gemein seinem gedicht / sonderlich bey diser Statt / geglaubt wurde / 
In discounting Müller's accusations, Tradel cultivates an official memory of the events that, in the course of fifty-three punctilious steps, relies on jurisdictional, legal, procedural and constitutional claims to counter Müller's version of the events.

The memory of the events leading up to the uprising of 4 June had clearly become a question of some considerable significance, quite obviously to the Augsburg magistracy. That Müller initially felt compelled to counter this official memory of events does not surprise, given his prominent position within the Augsburg Protestant community. But even years later, from the distance of his new life and professional commitments in Saxony, Müller remained committed to the cultivation of the oppositional Protestant memory of the events. Whether Müller continued to pursue the matter out of a residual sense of pastoral obligation to his Augsburg flock or whether he did so out of commitment to the Protestant cause in the increasingly acrimonious exchanges circulating in wider Imperial circles, Müller's crafting of the memory of events remained focused on the centrality of confessional identity. Like his first letter sent back to Augsburg in the early months of his exile in Ulm, this latest document, published in Wittenberg, adopted the voice of a concerned pastor for his congregants. In his Send- und Trostbrief an seine lieben Pfarrkinder in Augsburg ('Missive and Letter of Condolence to his Dear Pastoral Children in Augsburg'), Müller continued to attack the memory of events cultivated by Tradel and to which, in the meanwhile, most of the remaining ministers in Augsburg had acquiesced. ${ }^{23}$ Whereas Tradel and the council wanted to remember the events of $1583 / 84$ as centred around the a-confessional legality and constitutionality of the Empire's institutions, and Augsburg's own place in the Empire, Müller emphasised a memory centred on the Protestants in Augsburg as defined by their confessional affiliation. As Protestants, what befell them was an imitation of biblical precedents. However, in contrast to his earlier texts, Müller's own role was now amplified: Müller is now like David, who, in the Books of Samuel, after the death of Saul and David's ascension to the throne of Israel, was driven from Jerusalem by the Jebusites.

vnnd daselbst hero kein vertrawen oder Freündtschafft zwischen der Oberkeit / vnnd den Inwohnern derselben / vnmmermehr auffgepflantzt werden möchte ...; Der Herren Pfleger vnd Gehaimen Rät des heyligen Reichsstatt Augspurg Warhaffter gegenbericht.

${ }^{23}$ The pamphlet was published by Zacharias Krafft in Wittenberg (1586); see StadtAA, RS, EWA, No. 510, vol. 1. 
In accordance with his rejection of the political and legal frame of the official memory of the events, Müller could not see the council as magistrates, but rather as either Catholics or Protestants who happened to occupy an office in the magistracy. And because there were more Catholics than Protestants in the council in Augsburg in the 1580s, for Müller the magistracy is a Catholic magistracy. Müller recalled the events in Augsburg not as a matter of legal, constitutional or procedural dispute, but as an instantiation of confessional primacy, refracted through a biblical lens, which sees Augsburg's Protestants and now especially Müller himself as reiterations of the chosen people of the Bible. And because Tradel and those Protestant ministers in Augsburg who had accommodated themselves to council oversight and the calendar reform were likewise Protestants, they had to be revealed as false Christians. Noteworthy about Müller's continued efforts in cultivating a Protestant memory of the events in Augsburg is the degree to which his own movement from Augsburg to Ulm and later to Wittenberg parallels the way the crafting of a memory of the events of $1583 / 84$ had become as much an imperial as a local issue.

By this point, the memory of the events in Augsburg of $1583 / 84$ had developed along two divergent strands. On the one hand, there was an increasingly Empire-wide memory battle over whether the dispute in Augsburg was one of just civil authority and jurisdiction or confessional violence and depredation. This memory war was fought by the council on the one side and Müller on the other. Each enjoyed the growing support of imperial confessional networks of publishers and audiences keenly interested in the Augsburg affair. Just as the memory of Magdeburg or of the Bartholomew's Day massacre had become important chapters in the confessionalised memory of the Empire's Protestants, so too did the creation and maintenance of a certain interpretation of the 'Calendar Crisis' became a hallmark of imperial Protestant memory. The confessional steadfastness of men like Müller was celebrated as a model of Protestant conduct in Augsburg and in the Empire. Yet, while Protestants in confessionally uniform territories could openly celebrate their memory of the events in Augsburg in 1583/84, Protestants in Augsburg were foiled in similar efforts.

Just as the Augsburg council went to considerable lengths to refute Müller's missives both for a domestic and an imperial audience, it also set strict policies frustrating attempts by certain parts of Augsburg's Protestant community to live out a memory of the events of $1583 / 84$ as a religiously persecuted group. First, the council worked to prevent attempts to 
commemorate Müller. The council even charged the Protestant ministers with helping to reject any residual celebration of Müller in the citizenry, something that the ministers did, but to little effect. ${ }^{24}$ On the contrary, the ministers in Augsburg frequently complained of the abuse they suffered from their congregants. That is, those parts of the Protestant citizenry that identified with Müller were still able to implicitly challenge the council's version of the events as pertaining to constitutional or procedural matters. Though the council's authority could not easily be defied, the council's ministers - the so-called 'scabs' - could be boycotted. Ordinances forbidding baptisms outside the city or privately at home and those forbidding marriages elsewhere could not entirely prevent many of Augsburg's Protestants from seeing the events as a question of confessional identity. There was little that the council in Augsburg could do to stop this more passive form of resistance. However, the council was far more stringent in its enforcement of the use of the Gregorian calendar. Particularly in the years between 1586 and 1600 , it made considerable efforts to ensure that all artisans-including those in the more sensitive trades, like butchers-observed the calendar reforms in all of their dealings, whether it meant slaughtering cattle before Ash Wednesday or working on municipal construction projects during what, by the old calendar, was a Sunday. The municipal authorities used an extensive network of spies and informants to find out which weavers wove on a day that, by the new calendar, was a holiday. These people, so suspected the council, sought to live out in defiance of the municipal authorities their everyday lives in line with an interpretation of the events of 1584 as an episode of confessionalised martyrdom. ${ }^{25}$ Through such measures, the council in Augsburg sought to enforce public acceptance of its official memory of the troubles as a matter of legal and constitutional authority.

Nonetheless, since the judicial and occasional sources reveal a number of cases from the 1590 in which some of Augsburg's Protestant community continued to celebrate their feast days (and observe civil holidays) in accordance with the Julian Calendar, we can see that counter-memories of the events of the 1580 semained pervasive. In addition to observing the

24 One minister, Stephan Engelbronner, penned an appeal to the Protestant community in Augsburg, entitled 'Ein Kurze Aber Christliche vnd nottwendige / Vermahnung...', in StadtAA, RS, EWA, no. 511, doc. no. 46), but this document never seems to have made it past this draft stage.

25 See the judicial records (Urgichten) for the entirety of the second half of the 1580 s and the 1590 in StadtAA, RS. 
old calendar, some of Augsburg's Protestants demonstrated their commitment to commemorating the events of $1583 / 84$ by wearing white ribbons, something that between 1584 and 1586 had become a way to show loyalty to those who had fled Augsburg in the wake of the uprising of 1584 . These 'true hearts' represented their memory of the events as episodes in their confessionalised memory of the tumultuous years of the early $1580 \mathrm{os}$. Their continuing loyalty to and identification with those who had served as the ringleaders in the uprising of 4 June 1584 was as much a part of that confessionalised memory as was their continued observation of holidays according to the old calendar. This confessionalised memory animated a rather brisk cottage industry in penny pamphlets circulating throughout Augsburg and the Empire, which included songs of praise or sorrowful dirges for the sufferings of Müller and the Protestants in Augsburg. ${ }^{26}$ In contrast with the municipal memory of the uprising as a moment of civil disobedience and citizens' failure to respect imperially sanctioned and constitutionally prescribed authority, the events of the 158 os became for many of Augsburg's Protestants a basis on which to define themselves in marked difference to their Catholic neighbours. Though Augsburgers, both the leaders of the Protestant activist front and the municipal authorities, were able to lay formally to rest the debates over who had a right to name the ministers to serve in municipal churches and whether the calendar reform was to be implemented, there remained in the cultural landscape of Augsburg, for decades and, indeed, centuries, to come a difference in the way that many Protestants in Augsburg thought about the events of the early 1580 s.

Yet in the ability of Augsburgers to remain at peace while fostering such divergent memories of their own, common past, we can also see one reason why the city remained at peace despite all of the potential for conflict. What was effectively demonstrated was the degree to which diver-

${ }^{26}$ A collection of these songs can be found, transcribed, in SStBibAugsburg, $4^{\circ}$ cod. S 1, 'Collectanea zur Geschichte der Stadt Augsburg, 16. Jahrhundert'. It is very difficult to say with any certainty just how popular or widespread these songs were, but we can infer that they were popular enough from the fact that they were deemed worthy of careful transcription in this rather costly, fine volume. Alexander Fisher has discussed one of the most widely spread of the songs as reflected in the interrogation of its author, Abraham Schädlin (see his 'Song, Confession, and Criminality. Trial Records as Sources for Popular Music Culture in Early Modern Europe', Journal of Musicology 18, no. 4 (2001), 616-57). Allison Creasman, Censorship and civic order in Reformation Germany, 1517-1648. 'Printed poison \& evil talk' (Farnhamand Burlington, V.T.: Ashgate, 2012), esp. 147-184 has shown the lengths to which the municipal censors went in their efforts to stanch the flow of these texts in the civic spaces of the city's streets and marketplaces. 
gent memories could be accommodated even within the rigid structures of an early modern urban community. The memory of an event held among a particularistic confessional group was very much at odds with the official memory propagated by the political authorities. But that tension did not lead to open conflict. Instead, the one was relegated to the sphere of domestic sociability and private conscience and the other demanded public acquiescence. Though the official memory could not suffer the presence of a competing memory of the events in public spaces, it could not suppress the confessionalised memory cultivated at home. In Augsburg, the memories of these trying events thus mirrored a more general development that helped maintain peace in Augsburg in the years between the Peace of Augsburg and the coming of the Thirty Years War: politics, independent of confessional particularism, and a civic-mindedness centred on legal, social, and economic affairs were matters for public spaces and municipal business; confessional identity, matters of religion, as contemporaries put it, were restricted to the pews of churches and sermonhouses and to the privacy of citizens' homes. 
Erika Kuijpers, Judith Pollmann, Johannes Müller, and Jasper van der Steen - 978-90-04-26125-9 Downloaded from Brill.com04/26/2023 11:57:20AM via free access 
CHAPTER FIVE

\title{
TALES OF A PEASANT REVOLT. TABOOS AND MEMORIES OF 1514 IN HUNGARY
}

\author{
Gabriella Erdélyi
}

In April 1515, an ordinary priest from South Hungary, Clemens Canimich, submitted to Pope Leo X a petition confessing that:

When he [Clemens] was notary of a captain in the army of Thomas, the cardinal-primate and legate of the Holy See, and a crusade was declared [...] against the infidels, out of ignorance and because of the cowardice of the captain, he [Clemens] forged letters in the name of the Hungarian King and the Cardinal which were sent to the Christian faithful so that they should join the fight against the Turks. When many Christians had gathered [...], out of fear of the captain, and since he could not escape the peril of death otherwise, he took part in numerous battles, fights, pillaging, rape, arson and the murder of laymen and even clerics, which they perpetrated against Christians with the captain's troops. ${ }^{1}$

This account is a personal recollection of the events which are usually referred to as the greatest peasant revolt in Hungarian history. At first sight the story as Clemens told it six months after the event seems to be quite incongruous: why and how did he and his captain end up fighting against Christians if they originally summoned an army to take up arms against the Ottoman forces? Yet it made sense, nevertheless. The revolt had developed in response to a call for a crusade in 1514, in which peasants were ordered by pope and king to fight the 'infidel' Ottomans. When the nobility had tried to stop their peasants from leaving home during the busy summer season, the 'rustici cruciati' had turned against their 'infidel' landlords under the leadership of Georgius Dózsa, a Sekler lesser noblemen and soldier in the royal army. The rebellion was supported by many simple priests, who together with a new generation of Observant

\footnotetext{
1 Archivio Poenitentiaria Apostolica, Registra Matrimonialium et Diversorum [hereafter: APA], vol. 59, ff. $72 \mathrm{r}-\mathrm{v}$ (7 April 1515, Bachiensis diocesis). The present study was prepared within the framework of a research project funded by the Hungarian National Research Fund (OTKA-81435) and was supported by the Bolyai fellowship of the Hungarian Academy of Sciences.
} 
Franciscan friars had forged documents and used their preaching as an ideological tool to turn the war against the pagans into a war against the nobility. The uprising was put down in August 1514 by royal forces, and its military leaders were brutally and theatrically executed. ${ }^{2}$

Priest Clemens was one of the thousands of ordinary priests who had joined the peasants, and the first among fifteen who, in the decade up to 1525 , asked for the pope's absolution from the office of the Apostolic Penitentiary for partaking in warfare. By the fifteenth century the Penitentiary had become the chief and the cheapest route to both the salvation of souls and justice on earth in Renaissance Rome, handling violations of canon law ranging from irregular clerical ordinances and marriages to such heinous crimes as murder, sodomy or sacrilege. ${ }^{3}$ The petitioners discussed here, all of them clergymen, needed the papal pardon of their war crimes in order to repair their infringement of canonical rules and regain their clerical status. ${ }^{4}$

Although their stories were clearly influenced both by the procedure of issuing a pardon, which involved the transcription of a petition by a professional proctor who followed a prescribed protocol, and also by the legal demands to which they had to conform, petitioners were unquestionably the authors of their own narratives. While their accounts were intended to be efficacious, they also had to be authentic and truthful since the content was subsequently checked and had to be ratified by witnesses. As documents soliciting the benevolence of the pope, it was also essential that they be formulated very humbly and respectfully. ${ }^{5}$ Additional force

2 On the political and military history of the revolt see: Gábor Barta and Antal FeketeNagy, Parasztháború 1514-ben [Peasant War in 1514] (Budapest: Gondolat, 1973). On its leader, Georgius Dózsa see: 'Georgius Zekeltől Dózsa Györgyig' ['From Georgius Zekel to György Dózsa'], Századok 109 (1975), 63-88. On the manifold relations of the Hungarian province of Observant Franciscans to the revolt see: Jenő Szücs, 'A ferences obszervancia és az 1514. évi parasztháború. Egy kódex tanúsága' ['The Franciscan Observants and the peasant war of 1514'], Levéltári Közlemények 43 (1972), 213-263, and Jenő Szűcs, 'Dózsa parasztháborújának ideológiája' ['The ideology of Dózsa's peasant war'], Valóság (1972) no. $11,12-38$.

3 On the office of the Apostolic Penitentiary see most recently: Kirsi Salonen and Ludwig Schmugge, A sip from the 'Well of Grace'. Medieval texts from the Apostolic Penitentiary (Washington, D.C.: The Catholic University of America Press, 2009).

4 The so-called 'irregularitas ex delicto' was an impediment of priestly ordination. Willibald M. Plöchl, Geschichte des Kirchenrechts, 5 vols. (Vienna and Munich: Verlag Herold, 1955), vol. 2, 290.

${ }^{5}$ In this respect, the scenario of papal pardoning was very similar to the process of royal clemency in sixteenth-century France. Cf. Claude Gauvard, 'Le roi de France et l'opinion publique à l'époque de Charles VI', in Jean-Claude Maire Vigueur-Charles Pietri (eds.), Culture et idéologie dans la genèse de l'État moderne (Paris and Rome: École française de 
could be given to their stories if the supplicant went to Rome to present his petition to the Curia in person. Significantly, all the lesser clerics discussed here were prepared to invest the time and money to undertake such a trip, which suggests that these petitions were primarily a response to the risk of being reported to the diocesan authorities by local competitors; the rivalry among a growing mass of poor clerics for ecclesiastical offices was intense. ${ }^{6}$

Whereas the voices of the victors of the 1514 revolt are quite familiar to historians, these petitions to the pope provide a rare opportunity to hear the voices of the losing side. Research on collective violence often focuses on the motivation of agents and the relation between social status and the willingness to participate in a revolt. ${ }^{7}$ Historical scholarship on the events of 1514 has also been concerned primarily with such issues. ${ }^{8}$ Examining the petitions of the participants, however, provides us with a different perspective and makes it possible to construct a 'bottom up' narrative of the revolt. ${ }^{9}$ The autobiographical narratives constructed after the events enable us to explore the processing of the experience of collective violence. It has been observed that in the twentieth century collective violence tended to be followed by silence, with violent events becoming a taboo subject and only much later followed by a 'wave of speech'. Such a wave of speech can be interpreted either as a form of individual or collective therapy or as an attempt to stake a claim to monopoly over a 'true' version of events. In the verbal battle to establish authority over the

Rome, 1985), 353-366.; Hélène Millet (ed.), Suppliques et requêtes. Gouvernement par la grâce en Occident (XII $-X V^{e}$ siècle) (Rome: École Française de Rome, 2003); Natalie Zemon Davis: Fiction in the archives. Pardon tales and their tellers in sixteenth-century France (Stanford: Stanford University Press, 1987), esp. 57-59.

6 On the market of small benefices and the rivalry among lesser clergy in late-medieval Hungary see Gabriella Erdélyi, Szökött szerzetesek. Erőszak és fiatalok a késő középkorban [Runaway Friars. Violence and Youth in Late Medieval Hungary] (Budapest: Libri, 2011), 97-113, with further literature on the European context.

7 Clark McPhail, The myth of the madding crowd (New York: De Gruyter, 1991).

8 See the chapter on the social and economic standing of the peasantry in Barta and Fekete-Nagy, Parasztháború, 42-59; Ferenc Szakály argues that observant Franciscans joined the peasants because of their own their peasant origins, Mezőváros és reformáció. Tanulmányok a korai magyar polgárosodás történetéhez [Market-town and Reformation. Studies on the early phase of the rise of the burgess class in Hungary] (Budapest: Balassi Kiadó, 1995), 7-32.

9 See the landmark study by John Keegan, The face of battle. A study of Agincourt, Waterloo, and the Somme (London: Penguin, 1976), who first produced a battle narrative focussing on the experiences of common soldiers based on narrative sources. More recently on the culture of total war see Stéphane Audoin-Rouzeau and Annette Becker, 1914-1918: understanding the Great War (London: Profile Books, 2002). 
past, the 'possession' of the dead and claims to martyrdom are essential weapons. ${ }^{10}$

Generally speaking, war memories of the late medieval and early modern period are difficult to get at, due to the limited availability of sources as well as to the different structure of the public sphere. The memories of the Thirty Years War seem to be an exception to this rule, perhaps because in the war's immediate aftermath the events became a major source of contestation between Catholics and Protestants. Eventually, it was the Lutherans who succeeded in monopolizing the commemoration of the war: the annual commemorations turned into a celebration of their victory over their Catholic opponents. By the nineteenth century, however, the military Festkultur that flourished in the multiconfessional cities of Southern Germany was domesticated and turned into a celebration of peace. Framed as a cultural memory the Thirty Years War became a constitutive part of national identity. ${ }^{11}$

The memory of the 1514 revolt developed quite differently. Most recently there has been the rather robust claim that the revolt constitutes 'the unspoken trauma of Hungarian history, which was turned into a taboo right after the event and has remained so ever since.. ${ }^{12}$ Instead of offering a historical-psychological evaluation of the type inherent in this statement, I will apply a sociological approach to cultural trauma by seeking to reconstruct processes of remembering and forgetting after the 1514 peasant revolt. This sociological approach rests on the premise that the events themselves may become traumatic only subsequently, under the impact of narratives forged by historical agents sharing an interest in the making of trauma. ${ }^{13}$ To judge whether this was the case we need to

10 On the phase of repression followed by an outburst of speaking in the aftermath of the 1956 revolution in Hungary, see György Kövér, 'Források, értelmezések, történelmek' ['Sources, interpretations, histories'], in idem (ed.), A felhalmozás ive [The arch of accumulation] (Budapest: Új Mandátum, 2002), 391.

11 Hilmar Sack, Der Krieg in den Köpfen. Die Erinnerung and den Dreißigjährigen Krieg in der deutschen Krisenerfahrung zwischen Julirevolution und deutschem Krieg (Berlin: Duncker \& Humblot, 2008). I use the distinction between communicative and cultural memory introduced by Jan Assmann, Das kulturelle Gedächtnis. Schrift, Erinnerung und politische Identität in frühen Hochkulturen (München: Verlag C.H. Beck, 2007), 48-55.

12 Katalin Péter, A reformáció. Kényszer vagy választás? [The Reformation: coercion or free choice?] (Budapest: Európa, 2004), 73.

13 Jeffrey C. Alexander, 'Toward a theory of cultural trauma', in Jeffrey C. Alexander et al. (eds.), Cultural trauma and collective identity (Berkeley, CA: University of California Press, 2004), 1-30; Wulf Kansteiner, 'Finding meaning in memory. A methodological critique of collective memory studies', History and Theory 41 (2002), 179-197, esp. 186-187. 
ask who were the agents of trauma (or the dramatisation of memory) and what was at stake for them.

In the first part of my paper, I will briefly outline the dynamics of the memory war that followed the dramatic events of the revolt and address the question of how personal memory and identity formation interacted with public stories in petitions. In what ways did individual and collective memories shape representations of the violence? In the second part, I will sketch the later memories of the uprising in early modern cultural memory in Hungary and abroad.

\section{Rebels, Traitors, Infidels, and Barbarians}

The petition of priest Clemens makes no mention of the revolt, instead isolating and portraying the events as the outcome of a personal exchange between him and the cardinal:

Since, however, Holy Father, the petitioner was warned by the cardinal to desist from his acts [that is: illegal recruiting], he was excommunicated for his obstinacy, $[\ldots]$ which he regretted and regrets now. [...] He therefore asks to be absolved for homicide and other excesses and sins in return for due penitence and also to be suspended from divine services for a time. He would like though to keep his priestly office and benefices under the condition that he exercises penitence in front of the cardinal and humbly requests his forgiveness.

As we have seen, Clemens' effort to conceal the uprising and his role in it involves an incongruous story, starting with a proclamation of a crusade against the Ottomans and ending with Christians killing Christians. It is so peculiar that I suspect priest Clemens was one of the illegal preachers of the crusade who organised the uprising. His dissimulation may reflect the defensive reorganisation of his personal identity under the impact of the new social realities, which he must have perceived to be menacing. He composed his story in the aftermath of the uprising in a very tense situation dominated by anger and fear. Inevitably, his version of events was grounded in the brutal execution of the peasant leaders and the decree of the National Diet ordering the search for and execution of all rebels, who were called 'public malefactors', the murderers of noblemen and the rapists of virgins. ${ }^{14}$ Characterizing the reaction of the frightened nobility,

14 Corpus Juris Hungarici. Magyar Törvénytár 1000-1526, ed. Dezső Márkus (Budapest: Franklin Társulat, 1899), anno 1514/art. no. 4, 13, 14, 33. 
one sixteenth-century chronicler of the events noted that 'the Hungarian landlords behaved ruthlessly with the poor, oppressed the crusaders in many different ways' ${ }^{15}$

However, petitions from subsequent years reveal that the rebel memories of the revolt were suppressed only temporarily. As the bloody wave of noble revenge came to an end and the anticipated mass executions did not ensue, former rebels could resurface and present themselves publicly in the emerging memory war over the monopoly of legitimate violence and just war. We can witness the fabrication of the rebel myths penned by lesser priests from villages and market-towns situated in the heartland of the rebellion. In the dramatic story of the priest Benedictus of Nagyhatvan, written in 1519, the opposing protagonists are the crusaders and the nobility:

When a crusade against the infidels was declared in Hungary , and he himself took up the cross with many others, a conflict and quarrel erupted between the nobles and the crusaders, in the course of which the nobles attacked the crusaders. To defend themselves, he needed to take up arms too with his fellow crusaders. ${ }^{16}$

By attacking the crusaders as they were preparing to fight the natural enemies of Christianity, the nobles had taken the place of the Ottomans and had themselves become infidelis. This chain of thought must have appeared familiar in the papal Curia since it borrowed its central concepts from the papal bull declaring the crusade against the Turks. Both Pope Leo $X$ and the crusaders spoke of a 'holy' and 'praiseworthy crusade'. ${ }^{17}$ The pope had promised the remission of all sins for participants and supporters of the war while threatening absentees and those obstructing the war with excommunication on earth and eternal damnation in hell. The peasants could thus interpret the revolt as the realisation of the papal curse and replace the infidelis Turks with the infidelis landlords. ${ }^{18}$ Of course, this version of events countermanded the plot in the official stories of the ruling elite, in which the label infidelis had connotations of rebellion and treason and is used instead to as an attribute for the peasantry. ${ }^{19}$

15 1504-1566 Memoria Rerum, ed. József Bessenyei (Budapest: Magyar Helikon, 1981), 17.

16 APA vol. 64, ff. 111r-v (19 April 1523).

17 Monumenta rusticorum in Hungaria rebellium anno MDXIV (Publicationes Archivi Nationalis Hungarici II. Fontes 12), ed. A. Fekete Nagy - V. Kenéz - L. Solymosi - G. Érszegi (Budapest: Akadémiai Kiadó, 1979), 47.

18 Szűcs, 'Dózsa parasztháborújának ideológiája', 12-38.

19 See the exhaustive analysis concerning the characterization of the rebellious peasant in the different genres and sources produced in the sixteenth century by Gábor 
The voices of the verbal battle emerged in the geographical centres of the revolt (Abaúj and Zemplén Counties, the border region of Békés and Bihar Counties, the area around the city of Csanád, Bodrog and Bács Counties). The parties disputed who had been the aggressor, who had had to defend themselves, and which party had been (more) ruthless. On both sides, the dramatisation of events climaxed in a conspiracy theory.

After he had recruited many crusaders against the enemies of the Christian faith, and when they were ready for launching this honourable expeditionsuddenly, at the instigation of the enemy of humankind - the nobles attacked the crusaders. When the crusaders realised the betrayal of the nobility, they bravely started to defend themselves in order to save their lives.

This quote is taken from one of the rebel narratives by Nicolaus of Bihar, the chantry-priest of the parish church of the market-town of Bihar. ${ }^{20}$ In this account, penned in 1523 , the conflict is no longer attributed to the discord between the crusaders and the nobility but rather to the treachery of the latter. A very different conspiracy theory is elaborated in the counternarrative of a noble participant, Dionisious Kascach in 1525:

When his most reverend eminence, Cardinal Thomas, was sent as legate to Hungary in order to launch a crusade with royal permission and apostolic authority, some ignorant rebels and troublemakers rebelled against him and his followers, and took up the cross in order to kill his eminence and his followers. [...] Among them was the royal captain, Georgius Székely, too. [...] When he [the captain] discovered the fraud, he turned at once against the aggressors and rebels. ${ }^{21}$

The story of Dionisius is modelled on the plot developed in a humanist epic poem about a revolt in the cardinal's court: Stephanus Taurinus, Stauromachia id est Cruciatorum Servile Bellum, Vienna, 1519. In this Moravian humanist tale, events which had originally occurred in various locations and had very complex causes were all subsumed in one easily comprehensible conspiracy theory. It presents the crusaders as determined from the outset to exterminate the entire nobility under the pretext of the crusade led by a fraudulent and power-thirsty leader, Dózsa. ${ }^{22}$ The idea is repeated

Klaniczay, 'Images and designations for rebellious peasants in late medieval Hungary', in Balázs Nagy and Marcell Sebők (eds.), The man of many devices, who wandered full many ways ... Festschrift in Honor of János M. Bak (Budapest: CEU Press, 1999), 115-127.

20 APA vol. 7o, ff. 358v-359r (2 April 1523, Waradiensis diocesis). Bihar is today Biharia, in Romania.

21 APA vol. 73, ff. 157r-58r (3 January 1525, Wesprimiensis diocesis).

22 Stephanus Taurinus Olomucensis, Stauromachia id est cruciatorum servile bellum. Servilis belli pannonici libri V, ed. Ladislaus Juhász (Budapest: Egyetemi Nyomda, 1944). 
in the autobiographical account by another cleric, Gregorius Koppándi, from the landed nobility of Transylvania, who wrote in $15^{20}$ :

Many peasants gathered under the pretext of a crusade in the Kingdom of Hungary and revolted against the nobility with the intention to destroy them totally. Then, on royal orders he took up arms with the barons and nobles to destroy this huge peasant army. After they had defeated the peasants, he imprisoned forty peasants by the law of war, and considering the brutality the peasants had committed against nobles and clergymen, he made a peasant sit on a trunk and nailed his genitals and his buttocks to the trunk with iron nails, so that by punishing him, others would be terrified and deterred. ${ }^{23}$

The narrator obviously derived a strange pleasure from the detailed account which he volunteered here of the torturing of the peasant. Within the context of the memory war such details may seem surprising since they run counter to usual practice. When petitioners claimed in their formal written statements that they had committed legitimate violence, they refrained from any explicit, let alone literal, depiction of precisely what they had done. Instead, the legitimacy of their act was underpinned by brief references to the brutality of the enemy. The powerful, on their part, accounted for their bloody retribution simply with reference to their defence of the patria and their right to wage war. ${ }^{24}$ Our noble cleric was more talkative: it was possible for him to speak about his own extreme violence. The volubility of Koppándi is comprehensible when viewed in its contemporary context. In the late medieval culture of honour and the ritual processes of conflict negotiation which involved rites of both violence and law, there was much room for extreme but legitimate violence. ${ }^{25}$

In Hungarian: Taurinus, Paraszti háború [Peasants' War], trans. László Geréb (Budapest: Magyar Helikon, 1972). Taurinus belonged to the entourage of Cardinal Bakócz but later became the vicar of Franciscus Várdai, Bishop of Transylvania, who was the vice-legate entrusted by Bakócz to gather the army for the crusade in Transylvania. See also Várdai's petition to the pope after the revolt: SPA vol. 59, fol. 424r (August 1515).

23 APA vol. 66, ff. 52r-v (28 March 1520, Transylvaniensis diocesis). Gregorius probably describes one of the last battles fought at the castle of Bihar (July 1514) with the army of Pál Tomori, castellan of Fogaras (Fặgặras in Romania), who was his patron.

${ }^{24}$ For example Franciscus More, canon of Vác argued that 'alias atrocissima rabie illius rusticane thyrannidis in Regno Hungarie vigente' he fought 'pro domestica libertate conservanda', APA vol. 63, ff. 74r-v (1518); Franciscus Várdai, bishop of Transylvania: 'conflictibus et bellis iustis pro defensione patrie [...] armatus interfuit'. APA vol. 59, f. $424 \mathrm{r}(1515)$.

25 See the anthropological approaches towards violence, both interpersonal and collective, as well as the studies of legal anthropology: Daniel Lord Smail, The consumption of justice. Emotions, publicity, and legal culture in Marseille, 1264-1423 (Ithaca, N.Y-London: 
Koppándi depicted his violence as an act of law enforcement by arguing that he took part in a defensive war under royal orders and that he captured and punished the rebels in accordance with what was common wartime practice. In a similar vein, in subsequent petitions to the pope, those fighting a just war against the infidel Turks readily and extensively recounted their savage deeds. ${ }^{26}$ The sexual torture, mutilation and dehumanisation of the enemy served to exert power over the body of the rebels and, in this way, symbolically restore the social order. ${ }^{27}$ Rather than being brutal, Koppándi was being just. Furthermore, his story is a textual representation of the late medieval theatre of horror where public execution and the cruelties of warfare were the regulated and accepted sites of representing the body in pain. ${ }^{28} \mathrm{We}$ read the naturalistic portrayal of the execution of the 'peasant king' Dózsa in the humanist epos: 'The lymph burst forth abundantly from his broken skull, his brain bubbling out through his ears, mouth, and nose'. ${ }^{29}$ In 1514 a pamphlet entitled 'The Hungarians' crusade and the extreme cruelty committed on both sides' appeared in Rome. ${ }^{30}$ In its pages, the pious peasants who deemed themselves 'followers of the cross' are transformed into 'savage pagans' after they collectively rape noblewomen, but the climax of the story is the 'brutal, but well-deserved' death of the peasant leaders:

The leaders were immediately taken, and their naked bodies tied with irons to long stakes and burned alive on fire, some of them put on the cross, others skinned and left alive for some days. Some were quartered and fed to the dogs. ${ }^{31}$

Cornell University Press, 2003); Stuart Carroll, Cultures of violence. Interpersonal violence in historical perspective (London: Palgrave Macmillan, 2007).

${ }^{26}$ As did the Transylvanian nobleman Petrus Berekszói: once 'exercitum penes mare contra infideles haberet dictus exponens in dicto exercitu fuit et ibidem quamplures turcos $[\ldots]$ viros et mulieres cum parvulis manu propria interfecit, quandam etiam mulierem puerum lactantem manu propria interfecit et puerum etiam mortuum exinde credit'. APA vol. 3, ff. 397v-98r (1452).

27 Natalie Zemon Davis, 'The Rites of Violence' in her, Society and culture in early modern France (Stanford: Stanford University Press, 1975), 152-188.

${ }^{28}$ Péter Tóth G. 'A fájdalom metaforái. A testi fájdalom, a kegyetlenség és a vértanúság látványa a kora újkori Magyarországon' ['Metaphors of pain. The scene of bodily pain, brutality and martyrdom in early modern Hungary'], in Éva Pócs (ed.), Mikrokozmoszmakrokozmosz. Vallásetnológiai fogalmak tudományközi megközelítésben [MicrocosmMacrocosm. Concepts of religious ethnology in an interdisciplinary approach] (Budapest: Balassi Kiadó, 2001), 319-372, with further literature.

29 Taurinus, Paraszti háború, 65.

30 Janus Vitalis Panormitanus, De Ungarorum Cruciata facto anno 1514. et de infanda saevitia utrinque patrata, Roma 1514 in Monumenta rusticorum, 242-245.

31 Ibid., 245 . 
The staging of their torture had a moral, spiritual and aesthetic value in a communicative space distinct from the memory war. Moreover, reports such as these were trying to meet the increasing demand of an international public for news and entertainment. ${ }^{32} \mathrm{~A}$ pamphlet series published in German cities as the events unfolded during 1514 ended with an image of the peasant king crowned with a red-hot iron crown, being roasted on his throne and eaten by his fellows while listening to a $T e$ Deum laudamus. ${ }^{33}$ The author promised a second issue to update readers on the continuing fight on the battlefield, but this never appeared, as-we might guess - the appetite for horror of the readership was already well satisfied.

With regard to the Hungarian battle of words, we have seen how participants on either side, rebels and the powerful alike, fabricated conspiracy theories, transforming very varied individual motives and chaotic happenings into a linear and logical sequence of events. A process of smoothing personal and public memories into basic stories that made normative claims and aimed to shape the experience of those in the present and future alike seems to have been well underway, but it was still tied to the original setting of events. The accounts of those participants who remained outsiders to the subsequent memory war, however, have a very different narrative structure. Since they were not influenced by retrospective schemes of explanation and communal mythmaking, they remained far closer to the horizon of authentic individual experience of chaos and brutality. This can be observed in the story of Stephanus Mening, a cleric from Transylvania, who, four years after the events, did not even mention the uprising and used a biographical frame instead:

He was schoolmaster in the village of St. Ladislaus, when, together with other villagers living under the landlord Antonius Polner, he was forced by the threats and orders of the late Johannes Székely, and took up arms against the city of Segesvár. He did not intend to hurt, mutilate or kill anybody, and was unaware of the intentions of Johannes Székely, who broke

32 Péter Tóth G. 'A lator teste és a lator test. A bűnösség kultúrája a kora újkori Magyarországon és a büntetés-emlékeztetés problémája (vázlat)' ['The body of the rouge and the rouge body. The culture of sin in early modern Hungary and punishments as rites of memory. A draft'] Korall 5-6 (2001), 141-162, there 150.

33 Zeckel Jorg, Die auffrur so geschehen ist im Vngerlandt mit dem creutzern vnnd auch darbey wie man der creutzer haubtman hat gefangen vnnd getoedt [1514], in Monumenta rusticorum, no. 227; Paul Freedman also stresses the barbarous manner of Dózsa's execution which also astounded contemporaries. Paul Freedman, Images of the Medieval Peasant (Stanford: Stanford University Press, 1999), 269-270. 
into the house of the said landlord living in the city and killed him and his wife. On his road home, however, Johannes was murdered by the friends and kin of Antonius, in which he did not participate in any way. ${ }^{34}$

This well-known account of the uprising was modelled on the universal theme of feuding neighbours and on murder stories that never mention war at all. ${ }^{35}$ Four years later Mening again recounted his experiences through the lens of a direct participant: he said that he had been drifting with the crowd and had no idea whatsoever about what was happening to him. This may be realistic in the sense articulated by some theorists of collective violence, who argue that the majority are in the dark about what is going on around them and cannot foresee its possible consequences. ${ }^{36}$

There is no space here to elaborate on other examples, but such accounts by neutral 'outsiders' permit some generalisations about their narrative patterns. ${ }^{37}$ First, representations of violence in accounts of individuals who were not involved in the uprising differ from those in the public stories told in the context of the memory war. Outsiders remembered themselves participating in collective violence but denied having killed anyone personally, which suggests that it was possible to preserve the coherence of personal identity at the expense of making a taboo of interpersonal violence (a memory practice that has also been observed in individual memories of World War I). ${ }^{38}$ Interpersonal violence, however, resurfaced in the memory war, in which competing group identities were at stake and when there were political arguments to justify the use of extreme violence even outside the context of the normal suspension of everyday norms in wartime.

Given the barbarity of the enemy, war is frequently idealised and presented publicly as a fight of civilisation against barbarity. ${ }^{39}$ In the bloodthirsty 'public history' of the pamphlets, however, both parties were rendered as extremely cruel. Secondly, the centres of the memory war overlap with the intellectual and military centres of the revolt. Interestingly, these were exactly the same regions that in earlier decades had

\footnotetext{
${ }^{34}$ APA vol. 63, ff. 34r-v (1518).

35 See the royal donation letter from 1520 . Monumenta rusticorum, no. 383 .

36 This is called the irrational theory of collective violence, see McPhail, The myth.

37 Benedictus de Pellerd, presbyter Quinqeecclesiensis diocesis (APA vol. 63, ff. 38r-39r, 1518); Emericus Wolconz scolaris Zagrabiensis diocesis, (vol. 66, ff. 24v-25r, 1520); Georgius de Bodon, frater ordinis predicatorum Quinqueecclesiensis diocesis, (vol. 62, ff. $57 \mathrm{v}-58 \mathrm{r}$, 1517).

38 Audoin, Rouzeau and Becker, 1914-1918, 39.

39 For the modern analogy see ibid., 116.
} 
produced the bulk of long-distance pilgrims and where the evangelical teachings in following decades met with a quick and intense response. ${ }^{40}$ These paradoxical coincidences can most probably be explained, as Jenő Szücs has proposed, with reference to the presence of Observant Franciscans, whose friaries show a similar geographical distribution. ${ }^{41}$ This finding, in turn, suggests that the popular public sphere of the late fifteenth and the early sixteenth centuries was strongly shaped by the activity and preaching of these Observant Franciscan friars, which ranged from exhortations to take up the cross to anti-noble sermons and the spreading of spiritualist, messianic ideas.

\section{Dózsa, the Martyr}

In the $15^{20 s,}$ it was in the same places, and simultaneous with the memory war about the 1514 Revolt, that the first investigative campaigns against 'heretics' began. It is remarkable and surprising that during these inquests, the charge of heresy was never reinforced by identifying the accused as rebels, as Katalin Péter has noted. ${ }^{42}$ This decoupling is all the more remarkable since during the time of the bloody retribution for the peasant revolt of 1525 in Germany, the figure of the rebel and the Lutheran were totally fused. For example, a Würzburg pastor was put in prison by a landowner in 1525 because 'he preached the tenets of Luther and a rebellion' and was therefore considered a dangerous person 'liable to make the ordinary folk rebel in the future'. ${ }^{43}$ From the perspective of Catholic and Lutheran authorities alike, the German Lutheran was considered to be an insubordinate subject.

In Hungary, by contrast, the identities of rebel and Lutheran were not coterminous because the revolt was not instrumentalised in the construction of Catholic and Protestant identities. Instead of the figure of the

40 The regions in question are the Abaúj and Zemplén counties in the North-East; Csanád, Békés and Bihar counties in the Great Plain; and Bács-Bodrog in the South along the Danube. Cf. Enikő Csukovits, Középkori magyar zarándokok [Medieval Hungarian Pilgrims] (Budapest: MTA TTI, 2003), 188, and Szűcs Jenő, 'Ferences ellenzéki áramlat a magyar parasztháború és reformáció hátterében' ['Franciscan opposition movement in the background of the Hungarian peasant revolt and the Reformation'], Irodalomtörténeti Közlemények 78 (1974), 409-435, 426.

41 Szücs, 'A ferences obszervancia', 243-244.

42 Péter, A reformáció, 72-73.

43 Robert W. Scribner and Tom Scott (eds.), The German Peasants' War. A history in documents (London and New Jersey: Humanities Press International, 1991), document no. 149. 
rebel, the extreme brutality of the death of the 'peasant king' Dózsa later came to epitomise memories of the revolt. By that time, they were already disconnected from the original sites where the events had occurred. Thus, Stephanus Istvánffy, an early seventeenth-century chronicler at the court of the Habsburg king, introduced his lengthy description of the execution as follows:

I shudder at the thought of enumerating the horrible, extreme and unprecedented punishments of these miserable people. Since even if they deserved this terrible torture and death, it would nevertheless have rather suited pious Christians to subdue such a cruel massacre by piety and compassion. ${ }^{44}$

Looking at it from a century's distance, the experience of the theatre of horror of public executions seems to have undergone a profound shift. The image of the peasant leader sitting silently on a burning throne with a red-hot crown on his head and watching the execution of his brother while awaiting being quartered, displayed publicly, and finally devoured by his starved fellow-rebels continued to be reproduced in word and image (figures 2 and 3 ). It seems that this image persisted in the consciousness of the aristocracy and nobility since they were familiar with historical chronicles of the revolt and occasionally commissioned such texts. ${ }^{45}$ The memory of the revolt could thus be used to mobilise the paralyzed nobility in times of crisis. The aristocratic political leader, Palatine Nicolaus Esterházy (1625-1645) exhorted the nobility in 1632 with the following words:

You should remember the peasants' attack in the time of king Ladislaus, which caused huge bloodshed and the country's devastation. Those who have ever read the chronicles about it, will possibly know [...] that we will have to follow the example of John Szapolyai [who put down the revolt and ordered the executions] when acting against the peasants, not letting the traitors go and searching after them all possible ways. ${ }^{46}$

44 Nicolaus Istvánffy, Historiarum de rebus Ungaricis libri XXXIV (Cologne, 1622). Istvánffy Miklós magyarok dolgairól írt históriája Tállyai Pál XVII. századi fordításában [The history of Nicolaus Istvánffy in the XVIIth century translation of Pál Tállyai], ed. Péter Benits, vol. 1. (Budapest: Balassi, 2001), 141-142.

45 István Monok, A müvelt arisztokrata. A magyarországi fónemesség olvasmányai a $X V I-X V I I$. században [The erudite aristocrat. The readings of the Hungarian aristocracy in the XVI-XVII centuries] (Budapest-Eger: Kossuth, 2012), passim.

46 Letter of Esterházy to the nobility of Sáros county, 31 March 1632. Published in János Reizner, 'A Császár-féle Felső-Magyarországi 1631-1632. évi pórlázadás okmánytára' ['The documents of the Peasant Revolt led by Császár in 1631-1632'] Történelmi Tár 11 (1888), 128. 


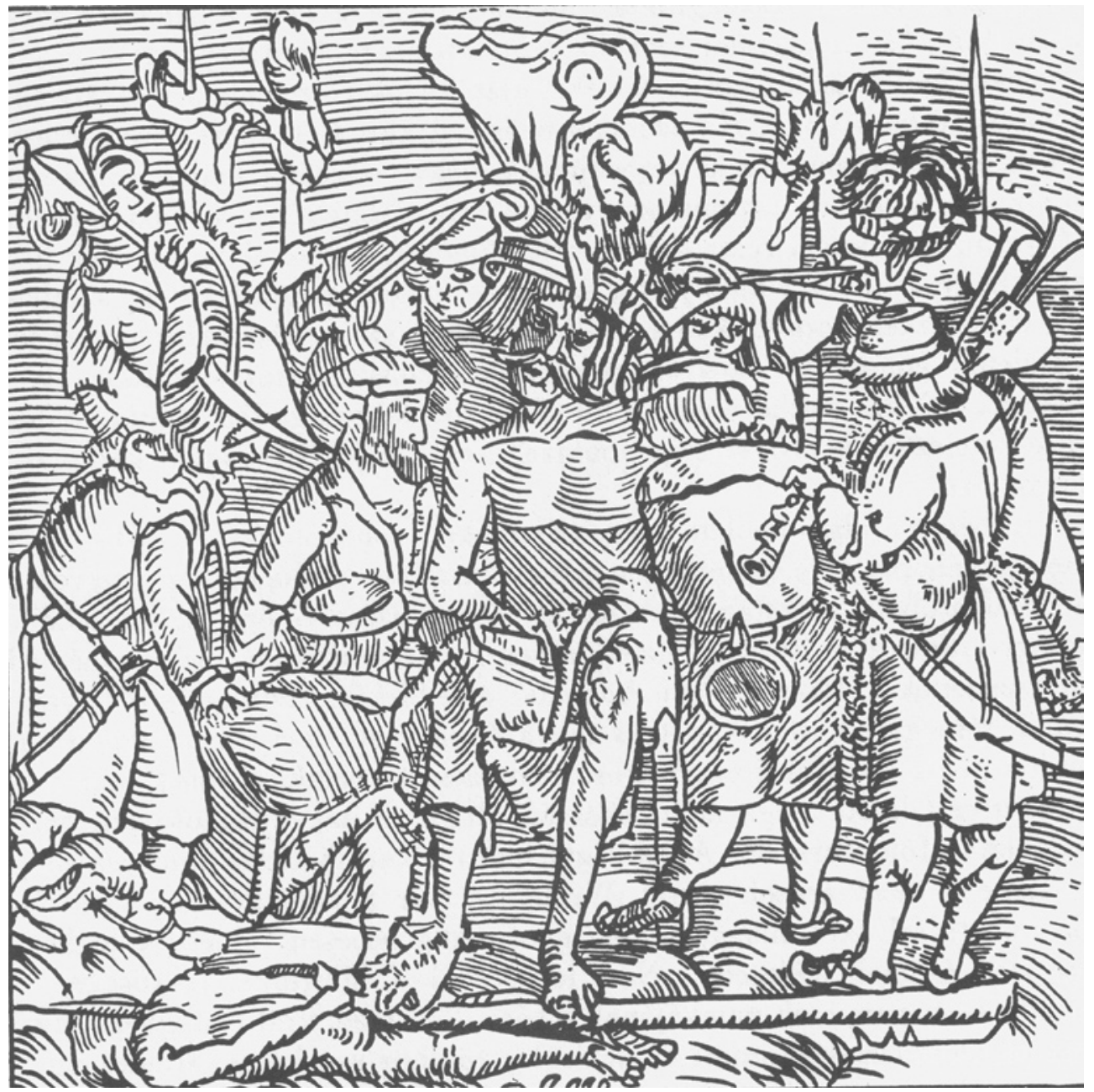

Fig. 2. The execution of Dózsa on the front page of Stephanus Taurinus, Stauromachia (Vindobonae, 1519), With the permission of the National Széchényi Library (Budapest), Régi Nyomtatványok Tára (Collection of Old Prints). 

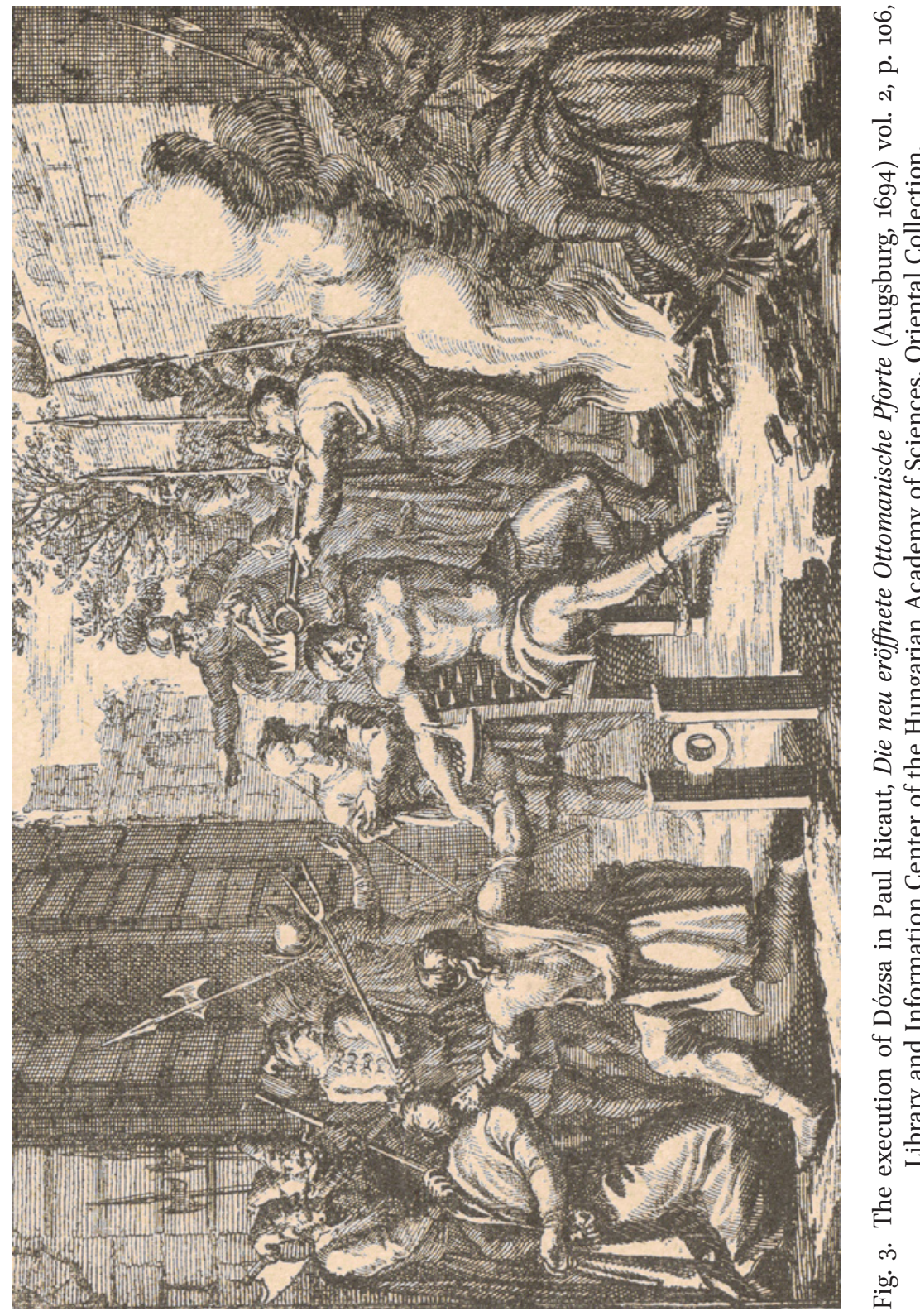
Esterházy was a man of his word. The leader of the 1632 peasant revolt, Peter Császár was tortured and his body quartered. ${ }^{47}$ From the sixteenth to the eighteenth century the ritual retributions for peasant revolts and other political rebellions became public occasions for remembering $1514 .{ }^{48}$ The public execution of early modern rebels reminded spectators of the sacralised death of Dózsa staging the passion of Christ and the ritual of holy communion. I would go so far as to speculate that the nobility's perceptions included even the Dózsa-Christ analogue. For them, the sufferings of the peasant rebel must have represented the deserved penance for the sins of his fellows, whose redemption in the afterlife must have seemed natural for them as well. The contemporary chronicler, Georgius Szerémi, a native of the region where the execution happened, recorded that Georgius Dózsa soon after his death was venerated as the 'second St George of Macedonia, the martyr' and the place of his execution became a site of pilgrimage. ${ }^{49}$ The above-mentioned chronicler Istvánffy commented on the execution of the leader Matej Gubec of the Croatian peasant revolt in 1572:

tearing dreadfully with burning pliers and crowned with a burning ironcrown and finally cut into four in the manner of thieves, he received the due punishment for his crime and usurpation of the royal title; he was punished with such severity, so that the elderly, who are still alive, would remember with horror the unfortunate assault of Georgius Sekler Dózsa who had wanted to extirpate the nobility. ${ }^{50}$

\section{Conclusions}

The ruling elite, who had learned to fear the peasants in 1514, engineered the staging of the dramatic memorialisation of the Revolt and then of its stigmatisation in subsequent centuries. Public executions were designed to deter crime and to legitimate power by reminding people of the consequences of rebellion and making them recoil from any repetition. We do not know how ordinary folk responded. If early modern spectators

\footnotetext{
47 László Makkai, A felsőtiszavidéki parasztfelkelés 1631-1632 [The peasant uprising in the Upper-Tisza region, 1631-1632] (Budapest: Müvelt Nép, 1954).

48 For further examples see Tóth, 'A fájdalom metaforái', 352-353, 359-36o.

49 Georgius Sirmiensis, De Perditione Regni Hungariae, trans. into Hungarian by László Juhász (Monumenta Hungarica V), (Budapest: Magyar Helikon, 1961), 68. The association of Christ's martyrdom with Dózsa's death was suggested by István Nemeskürty in 1983, Önfia vágta sebét [Wounded by his own son] (Budapest: Magvető, 1983), 164-166.

50 Istvánffy Miklós magyarok dolgairól, 485.
} 
remembered, identified with and experienced the pain when it was displayed on stage, as several scholars have suggested, they may have felt that this suffering contributed to their purification and salvation. ${ }^{51}$ In terms of the psychological concepts current today, the repeated recollection and staging of such painful events would have hindered mental healing and we would expect the pre-modern practice of public execution as a commemorative ritual to have worsened any collective traumas. But if 'nations can [freely] repress [and forget] with psychological impunity', 52 as Iwona Irwin-Zarecka has recently argued, we may have to conclude that the self-image of early modern society in Hungary was in fact stabilised by the cultivation in text, image and ritual of the martyr Dózsa and his crown of thorns. ${ }^{53}$

51 See for example Valentin Groebner, Defaced. The visual cultures of violence in the late middle ages (New York: Zone Books, 2004), 99-104.

${ }^{52}$ Iwona Irwin-Zarecka, Frames of remembrance. The dynamics of collective memory (New Brunswick, NJ: Transaction, 1994), 116.

${ }^{53}$ For this definition of cultural memory see Jan Assmann, 'Collective memory and cultural identity', New German Critique 65 (1995), 132. 
Erika Kuijpers, Judith Pollmann, Johannes Müller, and Jasper van der Steen - 978-90-04-26125-9 Downloaded from Brill.com04/26/2023 11:57:20AM via free access 


\title{
SHAPING THE MEMORY OF THE FRENCH WARS OF RELIGION. THE FIRST CENTURIES
}

\author{
Philip Benedict
}

In 1683, the historian Louis Maimbourg dedicated his Histoire de la Ligue to Louis XIV with some reflections about the past century. ${ }^{1}$ Although France was now a unified kingdom capable of dictating terms to the entire globe, he wrote, it had almost been destroyed in the sixteenth century by 'two baneful leagues of rebels'. 'Heresy formed the first against the true religion; ambition disguised as zeal gave birth to the second'. Mercifully, divine providence subsequently granted the house of Bourbon the glory of triumphing over both of these leagues. First Henry the Great defeated the 'League of False Zealots (Ligue des Faux-Zelez)' with his valour and his clemency. Then Louis the Just disarmed the Calvinists by capturing the strongholds in which they had established a form of rule contrary to monarchical sovereignty. Finally Louis the Great, through his combination of charity, zeal for the conversion of the heretics, and concern for the just application of the law, reduced the Protestant party to so weak a condition that its end seemed nigh.

Maimbourg's depiction of the later sixteenth century as a time of two baneful leagues reminds us that the history of how later generations recalled and passed along the story of the French Wars of Religion is a particularly complex one not merely because so many specific episodes of trauma, from local ambushes to larger massacres to political assassinations shook families, localities and the kingdom over nearly forty years of conflict, but also because the conflicts involved two different insurgent parties in two different phases with two different outcomes. The party whose emergence was central to the initial conflicts, the Protestant party, survived every threat to its existence and gained renewed legal recognition at every peace. The party whose emergence was central to the conflicts of the later phase, the Catholic League, was decisively defeated in what can be called the War of the Bourbon Succession from 1589 to 1598 . Since

\footnotetext{
${ }^{1}$ Louis Maimbourg, Histoire de la Ligue (Paris, 1683), 'épitre au roi'.
} 
the former group was present as a legally recognised religious minority from 1598 to 1685 and would live on even after the Revocation, each side in the initial Protestant-Catholic conflicts had descendants who judged it important to keep alive their side of a story that engendered dramatically divergent perceptions, justifications and memories. The League, however, had no posterity eager to transmit a positive account of its history across the generations. Many of its most committed members went into exile. Those who stayed in France and made their peace with Henry IV had a strong interest in seeing their prior opposition to the founder of the new ruling dynasty forgotten. Memories of this phase of the civil wars would be far less contested.

In the case of the French Wars of Religion, the tension between memory and forgetting present in all post-civil-war or post-regime-change situations was also distinctively shaped by the emphasis on oubliance in the peace-making efforts of the era. From the edict of pacification that ended the first civil war in 1563 through the Edict of Nantes, every edict of pacification that brought another civil war to an end enjoined those who had just been fighting one another to consider everything that happened in the prior tumults 'extinguished and as if they were dead, buried and had never happened', and to refrain from suing or provoking one another on account of what had happened. ${ }^{2}$ These amnesty clauses were meant chiefly to prevent lawsuits or vendettas arising from events of the justconcluded war, but contemporaries also understood them to set limits to what published historical works could recall. Two edicts of pacification, the 1576 and 1577 peaces of Beaulieu and Bergerac also forbade specific memorial practices, notably processions held to commemorate the death of the prince of Condé, Saint Bartholomew's Day, 'and other acts that might revive the memory of the troubles'. ${ }^{3}$ An explicit legal obligation if not to bury this era of the past in silence then at least to be very careful not to write, say or do anything about it that might provoke offense or discord thus remained in force from 1598 to 1685 .

Oubliance, however, had its limits - three important limits in particular. First, the terms of the Edict of Nantes based the rights of assembly of many local Protestant churches on the fact of their having regularly gathered at specific dates during the Wars of Religion. Disputes about or verification of these churches' right to exist led inexorably to appeal to the

2 André Stegmann (ed.), Édits des guerres de religion (Paris: Vrin, 1979), passim, esp. 36.

3 Stegmann (ed.), Édits des guerres de religion, 109, 143. 
historical record. Second, confessional identity and confessional rivalry were powerful antidotes to historical amnesia. For each side, recalling the hostile actions of the other reminded members of the community of the importance of continued vigilance and of the emptiness of the rival faith's claim to be the true Christian church. Third, the growing interest in the history of both the nation and the ruling dynasty during these centuries of early modern state-building, together with the fact that certain events simply could not be avoided in any coherent attempt to tell the story of the local or national community, ensured that historical examination of this period never ceased. And since the imperatives of critical history advanced among the learned as the century advanced, the manner in which these events were told became increasingly constrained by respect for documentary evidence and its critical evaluation. These last developments pulled the memory of the Protestant-Catholic conflict in a different direction from that encouraged by the ongoing confessional rivalry.

\section{The Initial Civil Wars and the Catholic-Protestant Struggle}

From the Conspiracy of Amboise in 1560 onward, France's 'troubles of religion' gave rise to rival stories of victimisation, vindication and deliverance through divine protection on either side of the confessional rift. The Protestants were the first to publish histories of these events in abundance, probably because, as a minority movement accused from the $1530 \mathrm{~s}$ onward of being seditious, they felt particularly compelled to justify their actions and to defend themselves against the charge of sedition. Their histories took many forms: the martyrologies that Jean Crespin and his continuators began to produce regularly from 1554 onward; short histories of specific events designed to spin them favourably for the cause; compilations of pamphlets and manifestos of which the Mémoires de l'estat de France sous Charles neufiesme (1576-1577) and the Mémoires de la Ligue (numerous instalments from 1587 to 1599 ) were the most copious and important; longer accounts of specific periods constructed on the model of Johann Sleidan's Commentaries on the State of Religion and Public Affairs under Charles V by Pierre de La Place (1565) and Louis Regnier de La Planche (1576); the collaborative ecclesiastical history of the first years of the Reformed churches in France published in 1580; and finally the fulldress histories of Lancelot Voisin de La Popelinière (1581) and Agrippa d'Aubigné (written between 1595 and 1612; published between 1616 and 1620). Although these histories often copied entire passages from one 
another, they did not agree on every detail of the stories they recounted. With the exception of La Popelinière, who self-consciously aimed to write a non-partisan account of these years 'as the good historiographer should do', they nonetheless all presented the Protestants as the victim of unceasing and illegitimate attempts to exterminate them who, when they had taken up arms, had only done so to protect themselves and the king against unlawful attempts by ambitious members of the clan of Guise to subvert royal authority and undo the toleration granted them in January $1562 .{ }^{4}$ This representation of the past quickly became a fundamental building block of Huguenot identity and political self-understanding, even if after 1620 few additional Protestant histories of the years 1560-1598 made their way into print. ${ }^{5}$ This is because the accounts of the massacres and civil wars drawn from the histories of religion and public affairs were integrated into later editions of the Acts of the Martyrs, which in turn became a staple of both individual and collective reading in French Protestant households, the most widely owned book after only the Bible and the Psalter. ${ }^{6}$ The influence of this initial corpus of early Huguenot histories also came to be felt beyond the Protestant community since these works were characterised by ample circumstantial detail and a strong concern to document their assertions through the direct citation of purportedly authentic records. This would impress later generations of historians of all perspectives. ${ }^{7}$

4 The literature on Huguenot historical writing is abundant. See in particular André Thierry, Agrippa d'Aubigné, auteur de l'histoire universelle (Lille: Service de reproduction des thèses, 1987); Jean-François Gilmont, Jean Crespin, un éditeur réformé du XVIe siècle (Geneva: Droz, 1981); Philip Benedict, Graphic history. The wars, massacres and troublesof Tortorel and Perrissin (Geneva: Droz, 2007), 125-129 and the works cited there; and Amy Graves-Monroe, Post tenebras lex. Preuves et propagande dans l'historiographie engagée de Simon Goulart (1543-1628) (Geneva: Droz, 2012). Huguenot historiography, memory and identity across the centuries was also the subject of a major conference held at Ascona, Switzerland in October 2010, the acts of which, edited by Philip Benedict, Hugues Daussy and Pierre-Olivier Léchot, are scheduled to appear in 2013 in the Publications de l'Association Suisse pour l'Histoire du Réfuge Huguenot under the title L'identité huguenote. Faire mémoire et écrire l'histoire (XVI $-X X I^{e}$ siècles). I have been able to draw with profit on many of the communications presented there.

5 Elisabeth Labrousse, 'Les guerres de religion vues par les Huguenots du XVII e siècle', in Philippe Joutard (ed.), Historiographie de la Réforme (Neuchâtel: Delachaux et Niestlé, 1977), 37-44.

6 One Huguenot household in eight owned a copy according to a sample of post-mortem inventories from seventeenth-century Metz. Philip Benedict, 'Protestant and Catholic book ownership in seventeenth-century Metz', in his The faith and fortunes of France's Huguenots, 160o-85 (Aldershot: Ashgate, 2001), 173, 188.

7 Henri Hauser, Les sources de l'histoire de France. XVIe siècle (1494-1610), 4 vols. (Paris: A. Picard, 1906-15), vol. 3, 14 . 
Catholic historians were slower to respond with histories of their own, more given to invective, and less concerned to document their assertions with the same appearance of care. Nevertheless, beginning with Claude de Sainctes' 1562 Discourse on the sacking of Catholic churches by the ancient and the new Calvinist heretics, quickly published in six editions between Paris, Verdun, Toulouse and Avignon, Catholics too produced histories and martyrologies that highlighted the subversive and violent actions of the Protestants, dwelled in pornographic detail on the torture of clergymen and the desecration of sacred objects, and hailed the Catholic champions who had preserved the faith. ${ }^{8}$ Also beginning amid the first civil war of $1562-1563$, Catholic authorities initiated commemorative processions to recall their deliverance from Huguenot takeover attempts or their liberation after a period of Protestant occupation.

When one compares the great majority of Catholic and Protestant histories of this period, one finds little common ground between them. Each side recalls its own victimisation and the other's violence. Accounts of the same event diverge sharply. A small number of chronicles of these years may nonetheless be situated at some sort of midpoint between the most partisan historians on both sides. For instance, the 'Short discourse and memoir of certain events in Normandy and France since the beginning of the year 1559, chiefly in Rouen', probably written by the Rouen canon Jean Nagerel, deplored the loss of life on both sides and found nothing to celebrate in the recapture of the city by the royal and Catholic forces in

8 This Catholic historiography has never been studied as a whole. Important works include Claude de Sainctes, Discours sur le saccagement des églises catholiques, par les hérétiques anciens, et nouveaux calvinistes, en l'an mil cinq cens soixantedeux (Paris and Verdun, 1562, Paris, 1563, Toulouse and Avignon, 1564, Paris, 1567, 1587); Pierre Belon, 'Cronique', published by Monica Barsi as L'énigme de la chronique de Pierre Belon. Avec édition critique du manuscrit Arsenal 4651 (Milan: LED, 2001); Georges Bosquet, Hugoneorum haereticorum Tolosae coniuratorum profligatio (Toulouse, 1563; French transl. Toulouse, 1595); Loys de Perussiis, Discours des guerres de la Comté de Venayscin et de la Provence: ensemble quelques incidentz, (Avignon, 1563; Antwerp, 1564, 1565); Loys de Perussis, Le second discours des guerres de la Comté de Venayscin (Avignon, 1564); Gabriel de Saconay, Discours des premiers troubles avenus à Lyon, avec l'Apologie pour la ville de Lyon, contre le libelle faussement intitulé: "La Juste et sainte défense de la ville de Lyon" (Lyon, 1569); Henri Hauser, 'Un récit catholique des trois premières guerres de religion. Les Acta Tumultuum Gallicanorum', Revue Historique 108 (1911), 59-74, 294-318; 109 (1912), 75-84; Jean Le Frere de Laval, La vraye et entiere histoire des troubles et guerres civiles, avenues de nostre temps pour le faict de la religion, tant en France, Allemagne que païs bas (Paris, 1573, 1574, 1575, 1576, 1578, 1582); 'De Tristibus Galliae', published by Léon Cailhava as De Tristibus Franciae Libri Quatuor (Lyon: Louis Perrin, 1840); François de Belleforest, Les grandes annales et histoire générale de France (Paris, 1579); Mémoires de Claude Haton, 4 vols. (Paris: Comité des Travaux historiques et scientifiques, 2001-07). 
October $1562 .{ }^{9}$ A moderate or moyenneur historiographic tradition also quickly took shape, albeit in a minor key. ${ }^{10}$

The edicts imposing oubliance and the urgency the crown felt to enforce them in certain times and places limited the circulation of the more partisan histories, especially on the Catholic side. A Catholic history of the Huguenot attempt to take over Toulouse in May 1562 that was published soon after the 1563 pacification edict of Amboise and that particularly offended against the principle of oubliance by naming the names of those who fought on both sides and by dwelling on the 'cruelties, indignities and barbarous acts' of 'the faction of Huguenots and Calvinists, miserable offspring of Luther' was immediately banned by the Conseil du Roi. All copies were ordered destroyed.11 Thereafter, partisan Catholic histories chiefly found their way into print from presses outside the kingdom in such places as Avignon, Turin and Antwerp or during periods when Protestant worship was not tolerated in France. Most Protestant histories were also published outside France, in Geneva, but its active presses and steady flow of men and books back and forth to France made it easier for the Protestants to get around the restrictions governing what might be said within the kingdom. The Protestants thus not only beat the Catholics to the punch in terms of writing extensive, well-documented histories in a manner concordant with their view of events; they got a higher percentage of their most important histories into print. While barred from print, however, partisan Catholic chronicles recalling Huguenot treachery, sacrilege and violence circulated in manuscript, as their textual history and citation in later local histories shows. ${ }^{12}$

9 Alexandre Héron (ed.), Deux chroniques de Rouen (Rouen and Paris: Société de l'Histoire de Normandie, 1900); Philip Benedict, 'Deux regards catholiques sur les premières guerres de religion à Rouen', in Jean-Pierre Poussou and Isabelle Robin-Roméro (eds.), Histoire des familles, de la démographie et des comportements en hommage à Jean-Pierre Bardet (Paris: Presses de l'Université Paris-Sorbonne, 2007), 735-740.

10 Another work in this key is Jean Philippi, 'Histoire des troubles de Languedoc, 156o16oo', published by Louise Guiraud, La Réforme à Montpellier, vol. 2, Preuves (Montpellier: Mémoires de la Société Archéologique de Montpellier, 1918).

11 Recueil de pieces historiques relatives aux guerres de religion de Toulouse (Paris: A. Abadie, 1862), 3 .

12 For evidence of the circulation of manuscript histories and how they were used, see Julien Blauf, Issoire pendant les guerres de Religion, ed. André Serre (Clermont-Ferrand: La Française d'Édition et d'Imprimerie, 1977), 11-20; L'invasion de la ville du Mans par les religionnaires en l'année mille cinq cens soixante et deux (Le Mans, 1667); Hilary J. Bernstein, 'Réseaux savants et choix documentaires de l'histoire locale française. Écrire l'histoire de Bourges dans la seconde moitié du XVII e siècle', Histoire Urbaine 28 (2010), 65-84, esp. $79-80$. 
In cities with a significant Huguenot presence, the clauses of edicts of pacification prohibiting Catholic commemorative processions were also generally applied to keep tension between the two communities from sparking violence, but in overwhelmingly or exclusively Catholic cities that had witnessed some form of Huguenot threat during the civil wars, they often were not. Here, such ceremonies lived on for centuries. Processions recalling a foiled Huguenot siege, 'surprise', or 'escalade' formed a regular part of the ceremonial year throughout much or all of the Ancien Régime in eleven cities that have been identified to date, and more cases surely remain to be discovered. ${ }^{13}$ These rituals regularly mobilised the participation of the local civil and ecclesiastical elites. They often included sermons recalling the event in question and warnings of the dire consequences that would follow if the plague of heresy contaminated the city again. The largest drew crowds of spectators estimated in the tens of thousands. They were thus powerful collective instruments for keeping alive stories of the danger that the Protestants had once posed to the community and might do again if not carefully controlled. ${ }^{14}$

In some of the same cities, the Catholic memorial tradition emphasising victimisation and deliverance was also passed along through paintings in the town hall recalling the city's resistance to a Protestant siege (as in Poitiers and Chartres) or local legends recalling how at a key moment in the fight against the Huguenots the Virgin or the patron saint of the city had come to its aid (as in Chartres, Verdun and Le Mans). ${ }^{15}$ Material

13 Philip Benedict, 'Divided memories? Historical calendars, commemorative processions, and the recollection of the Wars of Religion during the Ancien Régime', French History 22 (2008), 392, to which list can now be added the case of Auxerre.

14 André Sanfaçon, 'Légendes, histoire et pouvoir à Chartres sous l'Ancien Régime', Revue Historique 279 (1988), 337-357; André Sanfaçon, 'Evénement, mémoire et mythe. Le siège de Chartres de 1568', in Claire Dolan (ed.), Evénement, identité et histoire (Sillery Que.: Éditions du Septentrion, 1990), 187-204; Pascal Julien, “Assaut, invocation tutélaire et célébrations séculaires. Le 17 mai 1562 'delivrance de Toulouse' ", in Gabriel Audisio (ed.), Prendre une ville au XVIe siècle (Aix-en-Provence: Publications de l'Université de Provence, 2004), 51-62; Hilary Bernstein, Between crown and community. Politics and civic culture in sixteenth-century Poitiers (Ithaca: Cornell University Press, 2004), 179; Stefano Simiz, 'La mémoire catholique d'un échec protestant à travers les siècles. La tentative de surprise de Verdun en septembre 1562', Annales de l'Est 59 (2009), 129-139; Olivier Christin, 'Mémoire inscrite, oubli prescrit. La fin des troubles de religion en France', in Reiner Marcowitz and Werner Paravicini (eds.), Vergeben und Vergessen? Vergangenheitsdiskurse nach Besatzung, Bürgerkrieg und Revolution (Munich: Oldenbourg Verlag, 2009), 81-84.

15 Benedict, Graphic history, 110-111 and plates 5 and 6; Sanfaçon, 'Légendes, histoire et pouvoir à Chartres', esp. 347; Benedict, 'Divided memories?', 394-395; [Claude Blondeau?], L'invasion de la ville du Mans par les religionnaires en l'année mille cinq cens soixante et $\operatorname{deux}($ Le Mans: Louis Peguineau, 1667), 64. This last work also reveals that by the second 
objects could also testify to past events. An explosive device that failed to go off properly after the Protestants had planted it by a city gate in their effort to capture Le Puy by surprise in 1585 stood on display in that city's cathedral for generations. ${ }^{16}$

Even in cities that lacked public rituals of commemoration, other vectors perpetuated a Catholic martyrological tradition in clerical milieus and among some laymen. The Augustinian monastery in Lyon contained a painting depicting a prominent member of the order being flayed alive during the 1567 massacre of Catholics in Nimes, the Michelade. ${ }^{17}$ The hagiographic work of the friar Saint Martin, The Life of Saint Augustine and of several saints of his order (Toulouse, 1641), told the same story in print. ${ }^{18}$ A pious work in a different genre, the father Archange de Clermont's Jerusalem's Mount Calvary transported to France by the piety of a Dauphiné Catholic (Lyon, 1638), surprisingly includes a detailed account of the harassment of clergymen and confiscation of church property in Romans during the First Civil War based on solid research in the municipal registers from the period of Huguenot domination. ${ }^{19}$ Well into the eighteenth century, local histories dwelled at length on Protestant plots against the city or the violence and misery that accompanied periods of Huguenot domination. ${ }^{20}$

The Protestant counterpart to commemorative processions would have been the action de graces or thanksgiving ceremony, but no evidence has yet been found of a regular celebration of this sort in a Protestant stronghold in France comparable to Geneva's fête de l'Escalade or England's Guy Fawkes Day - which is not to say that further research might not uncover some. As the minority faith, however, the Reformed rarely controlled the public spaces and public rituals. During the seventeenth century, their martyrological and self-justificatory tradition survived chiefly

half of the seventeenth century these legends were beginning to be viewed with skepticism by the local learned elites. This phenomenon would become yet more marked in the eighteenth century.

16 Bruno Maes, Le roi, la Vierge et la nation. Pèlerinages et identité nationale entre guerre de Cent Ans et Révolution (Paris: Publisud, 2002), 138n.

17 Léon Ménard, Histoire civile, ecclésiastique et littéraire de la ville de Nismes, 7 vols. (Paris: Hugues-Daniel Chaubert, 1750-58), vol. 5, Notes, 4.

18 Ibid., vol. 5, Notes, 4.

19 Jules Chevalier (ed.), Mémoires du Pere Archange de Clermont pour servir à l'histoire des Huguenots à Romans 1547-1570 (Romans: R.S. André, 1887).

20 For a late example of a very common phenomenon: Calendrier historique de la ville de Lyon pour l'an de grace 1726 (Lyon, s.a.), 234-238 and Calendrier historique de la ville de Lyon pour l'an de grace 1727 (Lyon, s.a.), 239-264. 
in the intimacy of the community. The historical calendars printed for inclusion in many seventeenth-century Psalters reminded the faithful of major episodes of the Wars of Religion and especially of the massacres that had been the cause's lot. ${ }^{21}$ The abundant papers of the Metz minister Paul Ferry show that he devoted many studious hours to collecting information about the community's early history that could be drawn upon by the church's spokesmen if needed to defend its right of assembly. ${ }^{22}$ The reading notes of another pastor from later in the seventeenth century show him paying particular attention to the Book of Martyrs' account of the Saint Bartholomew's massacre and writing in the margin alongside its estimate of 30,000 killed 'or 100,000' ${ }^{23}$ Most tellingly, when at the approach of the Revocation, the political context in which the edicts of pacification had been granted and the history of the French Reformation more generally became a subject of intense public debate between Catholic and Protestant historians, the positions defended by the Protestants cleaved to exactly the same lines as those defended by the earliest selfjustificatory histories of the movement. ${ }^{24}$

Such would no longer be the case by the later seventeenth century among learned Catholic historians. While the martyrological, self-justificatory and commemorative traditions continued to be perpetuated in hagiography, in legends and in the public rituals of certain cities, an alternative view of the Wars of Religion had taken shape by this time among many of the most authoritative Catholic historians and their readers. This view depicted these conflicts as arising not from the seditious and sacrilegious actions of the heretics, but from the rivalry between the greatest noble families of the day, the overweening ambition of the house of Guise, and the character flaws of other key political actors, most notably Catherine de Medici.

At the fountainhead of this tradition stood the towering figure of Jacques-Auguste de Thou, who took as the primary lesson of his 3,400-page History of his own time that attempts to uproot heresy by banishment or

21 Benedict, 'Divided memories?', 388-389.

22 Julien Léonard, 'Histoire, mémoire et identités réformées chez Paul Ferry', forthcoming in Philip Benedict, Hugues Daussy and Pierre-Olivier Léchot (eds.), L'identité huguenote. Faire mémoire et écrire l'histoire (XVIe-XXIe siècles) (Geneva: Droz, forthcoming).

23 Philip Benedict, 'The owl of Minerva at dusk. Philippe Le Noir de Crevain, a pastorhistorian under Louis XIV', Faith and Fortunes, 255.

24 Philip Benedict, 'La conviction plus forte que la critique. La Réforme et les guerres de religion vues par les historiens protestants à l'époque de la Révocation', forthcoming in Benedict, Daussy and Léchot (eds.), L'identité huguenote. 
burning never worked, but instead only intensified people's commitment to their religious opinions and sparked wars that enabled the minority faith to reinforce its numbers and power. Written from a politique perspective in the wake of the League in which the Guises had so clearly played a leadership role, it had no difficulty accepting what had previously been the partisan Protestant view that the ambition and treachery of the house of Lorraine had been the chief cause of the early troubles as well. Sympathetic to toleration rather than concerned with justifying Catholic violence against Protestantism, it often relied upon early Huguenot histories. It broke with the prior Catholic historical tradition by recounting in detail the popular violence following Saint Bartholomew's day and even hinting that the massacre, which it clearly deplored, might have been premeditated. The extensive research on which it was based and its masterful Latin style, not to mention its sheer bulk, gave the work enormous authority. To suggest that the civil wars were born out of aristocratic rivalry, monarchical weakness and errors of policy-making, of course, was to imply that a country could live in peace even if it contained two religions so long as factionalism was brought to heel and a stronger crown pursued wiser policies. ${ }^{25}$

In the wake of De Thou, other leading historians such as Enrico Davila, François Eudes de Mézeray and Antoine Varillas also wrote essentially political narratives of this period whose accounts of individual events stood somewhere between those offered in the earlier, more partisan Protestant and Catholic accounts. Whereas the first Catholic histories to touch on the Saint Bartholomew's massacre presented it as a wholly justified response to previous Calvinist plotting and violence, these histories generally deplored the extent of the killing and made heroes of those local authorities who kept their city from re-enacting the Parisian bloodbath. ${ }^{26}$

25 Jacques-Auguste De Thou, Histoire universelle, 11 vols. (The Hague, 1740), esp. vol. 1, xlii-xlvii. De Thou's historical work still awaits an adequate treatment. I hope to explore his depiction of the Wars of Religion and its influence on the subsequent historiography of the subject further in future essays.

26 Enrico Caterino Davila, The history of the civil wars of France (London, 1678); François de Mézeray, Histoire de France, 3 vols. (Paris, 1685), vol. 3, esp. 1-3, 740-751; Antoine Varillas, Histoire de Charles IX (Paris, 1683). For the broader context of historical writing in seventeenth-century France and biographical information about these authors: Blandine Barret-Kriegel, Les historiens et la monarchie 4 vols., (Paris: Presses Universitaires de France, 1988); Orest Ranum, Artisans of glory. Writers and historical thought in seventeenth-century France (Chapel Hill: University of North Carolina Press, 1980); Steve Uomini, Cultures historiques dans la France du XVII e siècle (Paris: Harmattan, 1998); Christophe Blanquie, Un magistrat à l'âge baroque. Scipion Dupleix (1569-1661) (Paris: Publisud, 2008). 
By the latter half of the century, the new political vision of the civil wars was sufficiently powerful for substantial elements of it to be integrated into Bossuet's lessons for the dauphin; the history that the future bishop of Meaux dictated to his princely pupil even incorporated into its account of the Saint Bartholomew's massacre the story of Charles IX shooting at fleeing Protestants from a window of the Louvre, a purported detail of the event first recounted in the radical Protestant Reveille-matin des François and repeated by Mézeray. ${ }^{27}$ Not all prominent seventeenth-century Catholic historians accepted the broad interpretation of the late-sixteenthcentury conflicts as first and foremost aristocratic civil wars. Scipion Dupleix, writing during the 1620 s and 1630 s, explicitly defended the view that the conflicts were above all wars of religion and stressed that the Protestants were the first to begin the cycle of tit-for-tat violence and war crimes that marked the period. ${ }^{28}$ In the historical controversies of the era of the Revocation, a series of Catholic historians likewise reiterated the responsibility of the Calvinists for each new cycle of the civil wars in order to make the case that it was just to end the toleration of this inherently seditious heresy. ${ }^{29}$ Yet when these latter historians took up specific episodes of the troubles, they no longer narrated them as their sixteenthcentury predecessors had done. For instance, where previous generations of Catholic historians asserted baldly that the conspiracy of Amboise aimed to seize the king and overthrow the monarchy, the historians of this generation admitted that the evidence concerning the goals of the

Wilfred Evans, L'historien Mézeray et la conception de l'histoire en France (Paris: J. Gamber, 1930); Antoine Varillas, Les anecdotes de Florence, ou l'histoire secrète de la maison des Médicis ed. Michel Bouvier (Rennes: Presses Universitaires de Rennes, 2004), Introduction.

27 Régine Pouzet (ed.), Charles IX. Récit d'histoire par Louis Dauphin et Bossuet (ClermontFerrand: Adosa, 1993), 47, 239. On the place of the story of Charles IX's firing on the Huguenots in the memory of the massacre, see Philippe Joutard, Janine Estèbe, Elisabeth Labrousse and Jean Lecuir, La Saint-Barthélemy ou les résonances d'un massacre (Neuchâtel: Delachaux et Niestlé, 1976), 66, 105, 110-117, 153; Philip Benedict and Barbara Diefendorf, 'Religionskriege: Bartholomäusnacht', in Pim den Boer et al. (eds.), Europäische Erinnerungsorte, 3 vols. (Munich: Oldenbourg Verlag, 2012), vol. 2, 403-412.

${ }^{28}$ Scipion Dupleix, Histoire générale de la France, 3 vols. (Paris, 1644), vol. 3, esp. 568.

29 Louis Maimbourg, Histoire du Calvinisme (Paris, 1682); Pierre Soulier, Histoire des Édits de pacification et des moyens que les P.R. ont emploés pour les obtenir, contenant ce qui s'est passé de plus remarquable depuis la naissance du Calvinisme jusqu'à présent (Paris, 1682); Pierre Soulier, Histoire du Calvinisme, contenant sa naissance, son progrès, sa décadence, et sa fin en France (Paris, 1686); Jacques-Bénigne Bossuet, Histoire des variations des Eglises protestantes (Paris, 1688). See also Elisabeth Israels Perry, From theology to history. French religious controversy and the Revocation of the Edict of Nantes (The Hague: Martinus Nijhoff, 1973); Alfred Rebelliau, Bossuet historien du protestantisme (Paris: Hachette, 1891). 
conspirators was contradictory. ${ }^{30}$ Increased respect for documentary evidence and critical methods had reduced the degree of divergence between Catholic and Protestant accounts of the same events.

\section{The Memory of the Catholic League}

Since, as has already been suggested, the memory of the Catholic League was less contested, there is less to be said about it. Once Henry IV converted to Catholicism and secured the allegiance of the different League chieftains and cities, the dominant historical interpretation of what had just transpired was quickly fixed. As the first important historian of this conflict, the Protestant convert to Catholicism Pierre Palma Cayet, wrote, the war of the League had been 'a war for the state and not a war for religion'. ${ }^{31}$ The overweening ambition of the house of Guise had been the principal cause. Spanish and papal meddling had exacerbated the situation. If Catholic zeal entered into the equation, it was a false or deformed zeal. 'All forms of zeal are not good,' he wrote; 'the Holy Scriptures do not approve of those that are ill considered, extravagant and desperate'. ${ }^{32}$ The view first set forth in Palma Cayet's Chronologie Novenaire of 1608 and in the later chapters of De Thou's History of His Own Time still structured understanding of this era when Maimbourg sat down to write his Histoire de la Ligue on the eve of the Revocation. ${ }^{33}$ One dissenting history is known. Probably written by a Parisian robin around 1620, it downplayed foreign intervention and emphasised the concern of the movement's founders to defend the Catholic faith and the principle that the king of France must profess it. But it was never published, although it was preserved in the library of the Oratorians in Paris, where scholars might have consulted it. ${ }^{34}$

30 Maimbourg, Histoire du Calvinisme, 127; Soulier, Histoire du Calvinisme, 18.

31 Pierre-Victor Palma Cayet, Chronologie novenaire (Clermont-Ferrand: Paleo, 2007), 23.

32 Ibid., 24. See also Ann W. Ramsey, Liturgy, politics and salvation. The Catholic league in Paris and the nature of Catholic reform 1540-1630 (Rochester: University of Rochester Press, 1999), chpt. 4.

33 A brief overview of how successive epochs viewed the League is Marco Penzi, “'Damnatio memoriae'. La 'Ligue catholique française' e la storiografia, tra 'politiques', rivoluzionari, mistici e liberali”, Quaderni Storici 118 (2005), 263-284.

34 'Histoire de la Ligue', Bibliothèque nationale de France, mss Fonds Français 2329523296; Charles Valois (ed.), Histoire de la Ligue, oeuvre inédite d'un contemporain (Paris: Renouard, 1914), esp. viii; see also Paul Fournier's review of this edition, Bibliothèque de l'École des Chartes 76 (1915), 169. 
With the League generally disgraced and stigmatised, the less said about it the better most Catholics agreed, especially those descended from erstwhile Leaguers or attached to cities that had adhered to it. Seventeenth- and eighteenth-century local histories of former League strongholds regularly adopted the stance of Auxerre's Symphorien Le Beuf, who wrote that the city had sought to bury the era of League domination in eternal forgetfulness by destroying all of the archival documents concerning it, so he would do the same. ${ }^{35}$ Three generations of the Ruffi family of Marseille wrote histories that examined the period of the League in which their family had been deeply implicated. The descendants of the first generation buried their role in silence. Two generations later LouisAntoine de Ruffi claimed that they had sided against the League. ${ }^{36}$

What was most frequently recalled about this period was opposition to the League, Henry IV's skill in overcoming it, and the rallying to his banner in the wake of his conversion. When, early in the eighteenth century, an annual guide to Lyon's courts, government and trade fairs included instalments tracing successive eras in the city's history, the instalment devoted to the years 1568-1599 raced through the period of the League, asserting that it was not necessary to speak of the misfortunes of the time since they were common to the entire kingdom. It then highlighted that as soon as Lyon learned that Henry IV had embraced Catholicism, it recognised him as its rightful king, becoming the first major city to do so. As Paris had led the way to revolt, Lyon led the way to obedience. ${ }^{37}$ Paris, Dijon and Avallon held annual processions to recall the moment when they recognised the authority of the first Bourbon and opened their gates to him, while Senlis, a rare bastion of fidelity to Henry of Navarre in a region otherwise dominated by the League, commemorated the city's successful resistance against a siege by the forces of the Sainte-Union in $1589 .{ }^{38}$ Dijon's city council also met in a room whose inscriptions recalled

35 Quoted in Claire Dolan, 'L’identité urbaine et les histoires locales publiées du XVIe au XVIII ${ }^{\mathrm{e}}$ siècle en France', Canadian Journal of History 17 (1992), 284. Hilary Bernstein, who is currently researching local histories of the period 1560-1660, tells me that neglect of the period of the League is recurrent in the histories she has examined from this period.

36 Wolfgang Kaiser, 'Le passé refaçonné. Mémoire et oubli dans les Histoires de Marseille, de Robert Ruffi à Louis-Antoine de Ruffi', Provence Historique 193 (1998), 279-292.

37 Calendrier historique de la ville de Lyon pour l'an de grace 1728 (Lyon: André Laurens, s.a.), 286-287. The same boast appears in Claude de Rubys, Histoire véritable de la ville de Lyon (Lyon, 1604), 450.

38 Benedict, 'Divided memories?', 393; Michel Cassan, 'Conclusion', in Michel De Waele (ed.), Lendemains de guerre civile. Réconciliations et restaurations en France sous Henri IV (Quebec City: Presses de l'Université Laval, 2011), 256; Thierry Amalou, Le Lys et la Mitre. 
several mayors who had opposed the League and secured the city's return to obedience to its rightful king. ${ }^{39}$ Processions commemorating the end of the League nonetheless seem to have been considerably less common than those recalling a city's deliverance from an attempted Protestant takeover.

For politique Catholics, the League was also worth recalling as an object lesson in the dangers of excessive clerical intervention in politics. One notorious episode encapsulated this message: the 1590 parade of clergymen and students armed to defend Paris under siege in the course of which one gun-toting friar accidentally shot a member of the papal legate's entourage. Numerous painted and graphic versions of this Procession of the League are known, several of which drive the message home with the Lucretian inscription 'Tantum religio potuit suadere malorum' (to such evil are men driven by religion). So popular was this image that a character in Agrippa d'Aubigné's 1630 Les Aventures du Baron Faeneste speaks of having 'seen these paintings in all the great houses' and asks the baron to acquire one for him. ${ }^{40}$ Seventeenth-century re-printings of the Satyre Ménippée also made members of the learned elite familiar with its burlesque account of the 1593 Estates General. Seventeenth-century Protestant historical calendars noted episodes such as the Sorbonne's call to refuse obedience to Henry III after the killing of the duke and cardinal of Guise. ${ }^{41}$ Come the eighteenth century and Voltaire's enormously influential epic the Henriade, these events, and the history of the League more generally, would assume a still larger place in the national memory, now as a synecdoche not for the dangers of false zeal, but of zeal tout court.

To conclude, forgetting was much easier when one side in a conflict had been definitively defeated than when its descendants remained to preserve and defend their understanding of a contested past, and indeed

\footnotetext{
Loyalisme monarchique et pouvoir épiscopal pendant les guerres de Religion (1580-1610) (Paris: Éditions du CTHS, 2007), 352-356, 449.

39 The former council chambers are today the reading room of the Archives Départementales de la Côte-d'Or, where the inscriptions can still be seen.

40 Cited in Tom Hamilton, "The 'procession de la Ligue'. Parisian processions and their representation toward the end of the wars of religion", unpublished paper. I have relied heavily on this paper for my discussion of this image and wish to thank Mr. Hamilton for sharing his research with me. Paintings of the Procession de la Ligue may be found in the Musée Carnavalet in Paris, the Musée de l'Histoire de France in Versailles, and the Musée des Beaux-Arts of Rouen. For engraved versions see G. Duplessis, Inventaire de la collection d'estampes relatives à l'histoire de France, leguée en 1863 à la Bibliothèque Nationale par Michel Hennin, 5 vols. (Paris: Menu, Picard, Champion, 1877-84), nos. 1033-1038.

41 Benedict, 'Divided Memories?', 383, 405.
} 
had quickly produced a large, well-documented corpus of histories about the subject. Despite the clauses of oubliance, starkly polarised rival views of the Protestant-Catholic conflicts of the Wars of Religion were preserved in many histories and martyrologies of both sides, in the public rituals and iconography of certain overwhelmingly Catholic towns, in Catholic legend, and in Huguenot historical calendars. From the turn of the seventeenth century onward, however, the sharply polarised rival historical accounts of both parties that dwelled overwhelmingly on the evils done to their camp were increasingly challenged and partially displaced by ones that emphasised personal rivalries and poor political decision-making as the causes of conflicts and that moved the narrative of events toward a common ground that owed a great deal to the earliest Protestant accounts of events. The story of the League was far less contested and changed less over time. There was simply nobody to defend the cause nor any authoritative published histories transmitting an alternative view. 
Erika Kuijpers, Judith Pollmann, Johannes Müller, and Jasper van der Steen - 978-90-04-26125-9 Downloaded from Brill.com04/26/2023 11:57:20AM via free access 


\section{PART TWO}

\section{MEDIALITY}


Erika Kuijpers, Judith Pollmann, Johannes Müller, and Jasper van der Steen - 978-90-04-26125-9 Downloaded from Brill.com04/26/2023 11:57:20AM via free access 


\section{CELEBRATING A TROJAN HORSE. MEMORIES OF THE DUTCH REVOLT IN BREDA, 1590-1650*}

\section{Marianne Eekhout}

In 1866 the chief inspector of the fortifications of the Dutch city of Breda signed an affidavit testifying that he had found a piece of peat inside one of the brick walls of the city's castle. Joined together by a piece of string, peat and affidavit were allotted to the collection of the provincial museum of Brabant, where they still can be found today. ${ }^{1}$ To understand why this piece of peat was handled with such care, and ended up in a museum, we need to go back to the year 1590, when Breda was recaptured by the Dutch Republic from Alessandro Farnese, governor of the Habsburg Netherlands. This was no ordinary attack, however, but one that was achieved by stealth. Seventy Dutch soldiers were smuggled into the city while hiding in the barge of the local supplier of peat to the castle of Breda. Once inside the castle, soldiers overpowered the small Italian garrison and recaptured the city. ${ }^{2}$

Although the peat's provenance was endorsed only through its place of discovery, its presence in the castle apparently reminded officials in nineteenth-century Breda of the way the soldiers hid in the barge, the cunning manner in which the attack had been prepared and executed, and the excellent outcome of this endeavour. It was these circumstances that rendered a simple piece of peat found in a wall of the castle into a significant find and an illustration of how a vivid memory culture surrounding the peat barge had developed in Breda. Yet, in the seventeenth century the local commemoration of the attack of 1590, and the role which

* Research for this article was funded by an NWO VICI grant for the research project Tales of the Revolt. Memory, oblivion and identity in the Low Countries, 1566-1700, and with support of the IAP project City and Society in the Low Countries, 1200-1850.

1 Noordbrabants Museum, 's-Hertogenbosch, inventory number 05957.

2 J.P. Meeuwissen, "'... de onderste turven levendich', het verhaal van de inname", in J.F. Grosfeld et al. (eds.) 1590-1990. Het Turfschip van Breda (Breda: Breda's Museum, 1990), 18-39. 
memories of this event would play in Breda's urban community had not been self-evident.

While the memory culture around most of the events during the Dutch Revolt against the Habsburg authorities started on a local level and was incorporated into a 'national' memory canon at a later stage, the commemoration of the peat barge seems to have developed the other way around. The ruse of the peat barge was celebrated immediately as a new Trojan horse in pamphlets and news tidings all over the Northern Netherlands. In these media, Breda appeared only as the scene of action. ${ }^{3}$ There were good reasons for common 'national' interest in the peat barge attack: the attack had been organised and executed by the army of the Dutch Republic, without any help or interference from the people inside the city of Breda. The heroes of this episode were not the locals of the Brabant town but the brave soldiers of the States' Army. Furthermore, the attack on Breda was celebrated as the beginning of a series of victories by Stadholder Maurice, which was to last for ten glorious years. ${ }^{4}$

In Breda itself, there was less to celebrate. The city's population had been loyal to its Habsburg rulers. Moreover, the citizens of Breda did not have their own stories of the event to remember. The peat barge attack was directed against the castle instead of the city, and the magistrate of Breda had refused to let the soldiers in. It was the soldiers and skippers who manned the barge who kept the personal memories of the coup alive. ${ }^{5}$ Nevertheless a local memory culture surrounding the peat barge began to emerge in the first decades of the seventeenth century. Paradoxically, the memory of the peat barge finally became so dominant that other crucial events in the town were overshadowed by it. Even though the town suffered two more sieges during the first half of the seventeenth century, in 1624-25 by the Spanish army and in 1637 by the Dutch army, these episodes left fewer traces in the local memory culture. While in other cities, such as Haarlem and Leiden, memories of sieges were incorporated into the civic memory canon, Breda continued to commemorate the memories

3 Histoire memorable de la reprinse de la ville et chasteau de Breda au pays de Brabant, au mois de mars, 1590 (Middelburg, 1591), 5; Een nieu Geusen Lieden-Boecxken (The Hague, 1592), f. 71 .

4 Simon Groenveld, 'De man met de loden schoenen. Een levensschets', in Kees Zandvliet (ed.) Maurits, Prins van Oranje (Amsterdam: Waanders, 2000), 82-151, there 23-24; A.Th. van Deursen, Maurits van Nassau, 1567-1625: de winnaar die faalde (Amsterdam: Bakker, 2005), 58-59.

5 Simon Vosters, 'Een Spaans soldaat over Breda ten tijde van Parma', De Oranjeboom 13 (1960), 102-120, there 112, 118. 
of the peat barge instead. ${ }^{6}$ The Brabant town was therefore rather unique in its appropriation of a national attack with slim connections to the local community.

The aim of this article is to understand how the peat barge developed as the dominant memory of the Dutch Revolt in Breda during the seventeenth century. I will investigate who was involved in this process and ask why the sieges of 1625 and 1637 do not seem to have influenced the existing memory culture of the 1590 peat barge attack. In the literature on Breda, some of the answers to these questions can be found, as the political and religious impact of the peat barge attack on the city and its elite have been studied thoroughly. Yet, most historical research on the issue has concentrated on the period between 1590 and 1625 , and again after 1637 when Breda once more became part of the Dutch Republic. ${ }^{7}$ Moreover, existing studies have focused either on the peat barge or on the two sieges and have not tried to explain why the events of 1590 were commemorated so much more extensively than the sieges. To do so we must analyse the development of the local memory culture in a long-term perspective. In this article, I will therefore explore the commemoration of the peat barge attack from 1590 until the end of the seventeenth century and consider the evolution of this iconic event as a constitutive part of civic memory in Breda in order to show how this memory reached its iconic status.

This chapter will examine a wide range of material sources. Most of this material has already been described in an exhibition catalogue in 1990, during the celebration of the 40oth anniversary of the peat barge attack. ${ }^{8}$ Still, these sources have never been examined as constituting a broader so-called 'memory landscape' which not only analyses objects

\footnotetext{
6 See for example Judith Pollmann, 'Een "blij-eindend" treurspel. Leiden, 1574', in Herman Amersfoort et al. (eds.) Belaagd en belegerd (Amsterdam: Balans, 2011), 118-145; Marianne Eekhout, 'De kogel in de kerk. Herinneringen aan het beleg van Haarlem, 1573-1630', Holland. Historisch tijdschrift 43 (2009), 108-119.

7 See for example, Simon Groenveld, "Breda is den Bosch waerd" Politieke betekenis van het innemen van Breda in 1625 en 1637', De Oranjeboom 41 (1988), 94-109; Marijke Meijer Drees, 'Liever een rechtvaardige oorlog dan een geveinsde vrede. Politieke propaganda in een vroeg zeventiende-eeuws toneelstuk over het turfschip van Breda', De Oranjeboom 43 (1990), 1-15; R.H.M. van Immerseel, Breda 1568-16oo. De politieke elite in een frontierstad (Breda: Gemeentearchief Breda, 1999); Ton Kappelhof, 'De stedelijke financiën van 's-Hertogenbosch en Breda onder de Republiek', TSEG 3 (2006), 96-117; F.A. Brekelmans, 'Aanzien en luister van de stad Breda van de 16de tot de 18de eeuw', Bijdragen tot de Geschiedenis 68 (1985), 157-172.

8 Grosfeld et al. (eds.), 1590-1990: Het Turfschip van Breda.
} 
and textual sources in conjunction but also maps who had access to different material and immaterial sources. This approach therefore enables researchers to examine both the dynamics and the reach of early modern memory cultures.

\section{The Celebration of a New Trojan Horse}

On 4 March 1590 the city of Breda was captured by the Dutch. An ordinary peat barge, disguised to smuggle seventy soldiers, entered the castle of Breda and subsequently overpowered the garrison and forced an entry into the city. The plan for this attack had been the work of Stadholder Maurice and Holland's advocate Johan van Oldenbarnevelt with the help of the barge's skipper. Because the soldiers at the gate knew the skipper they did not search his boat properly, and at midnight, after several hours of waiting, the soldiers overwhelmed the guard from within the castle. ${ }^{9}$ Within the city of Breda the magistrate tried to convince the Italian garrison of the castle to fight, but once the city authorities realised that Maurice's army was approaching and further resistance was pointless, they changed their tune and celebrated victory. Breda had been liberated by the States' army and joined the Dutch Republic. ${ }^{10}$

For Stadholder Maurice and the States General the conquest of the strategic city of Breda was a breakthrough in the war against the Habsburg Netherlands and marked the beginning of a successful sequence of other triumphs in cities such as Zutphen, Deventer, Hulst, Nijmegen and Groningen. Moreover, the outcome and execution of the attack proved that the States' army could achieve victory without casualties due to fire, pillaging or fighting. ${ }^{11}$ Soon the news of the Dutch Trojan horse spread through the Low Countries in poetry, prints and beggar songs. ${ }^{12}$ Inspired by the excitement of the news of Maurice's first great victory, the national festivities in

\footnotetext{
9 Meeuwissen, '... de onderste turven levendich', passim.

10 Ibid., 35 .

11 Groenveld, 'De man met de loden schoenen', 23-24; Van Deursen, Maurits van Nassau, 58-59.

12 Anton van Duinkerken, 'Het Turfschip van Breda als poëtisch motief', De Oranjeboom 10 (1957), 12-47, there 20-27; Frans Hogenberg, Breda door verrassing ingenomen, 1590, Scheepvaartmuseum Amsterdam and Stadsarchief Breda, Breda Beeldcollectie, nr 1989 1855; Christi Klinkert, Nassau in het nieuws. Nieuwsprenten van Maurits van Nassaus militaire ondernemingen uit de periode 1590-160o (Zutphen: Walburg Pers, 2005), 70-75.
} 
1590 were extensive. The success was celebrated in many cities across the Low Countries with bonfires, bell ringing and church services. ${ }^{13}$

The significance of Breda's capture for the States General was also expressed in the way they celebrated the victory. Both the States General and individual provinces issued copper and silver jetons to mark the events. These jetons, which were used by officials to assist them in collecting taxes, were seen by many and so propagated the importance of the attack throughout the Low Countries. ${ }^{14}$ Besides these jetons, the States General commissioned commemorative medals depicting their victory, for all the participants in the peat barge attack. This commission represented the first time such a medal was issued and started a tradition for other memorable events during the Revolt. This medal was made out of gold and worth twenty-four guilders, a small fortune for the soldiers and skippers involved in the attack (figure 4$).{ }^{15}$ On top of this reward, the soldiers and skippers received two months' pay from the city of Breda and other financial compensation. ${ }^{16}$

The magistrate of Breda, after their initial reluctance to let the States' army into the city, now became actively involved in rewarding their conquerors with gifts. When the States General decided to purchase the damaged peat barge from the skippers to compensate them for their loss, it was taken out of the water to be put on display on the docks. Originally, the States General had agreed to sink the ship in the castle of Breda in eternal commemoration' of 1590 but soon it became clear that a sunken barge would block the city's waterway. ${ }^{17}$ The decision to lift the barge out of the water and to put it on display ensured that the city of Breda possessed the most important reminder or 'relic' of the (soon to become) legendary peat barge attack. In 1625 it was said to have been on display on

13 Meeuwissen, ‘... de onderste turven levendich', 35.

14 Rijksmuseum Amsterdam, inventory numbers NG-VG-3-726, NG-VG-3-727-A, NG-VG-3-727-B and NG-VG-3-727; Jaco Zuijderduijn, 'Schuiven, schenken, strooien, of sparen? Het gebruik van rekenpenningen in de 16de eeuw', Holland. Historisch tijdschrift 43 (2011), 24-36, there 27-30.

15 Resolutiën der Staten-Generaal 7 (1590-1592), ed. N. Japikse (The Hague: Martinus Nijhoff, 1923), 22.

16 Ibid., 20-22; Stadsarchief Breda (SAB), ARCooo1, number 2483, Stukken betreffende de uitbetaling van twee maanden soldij door de stad Breda aan twee compagnieën bij de inname van de stad door staatse troepen.

17 Meeuwissen, '... de onderste turven levendich', 38; Japikse, Resolutiën 7 (1590-1592), 22. 


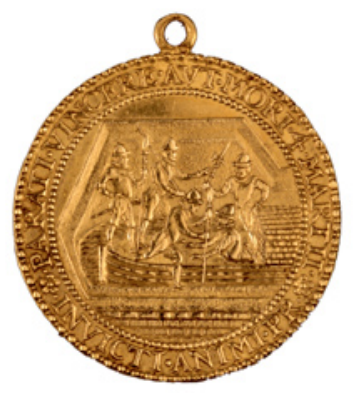

Fig. 4a. Gerard van Bijlaer, commemorative medal peat barge of Breda, 1590, gold, Noordbrabants Museum 's-Hertogenbosch, front.

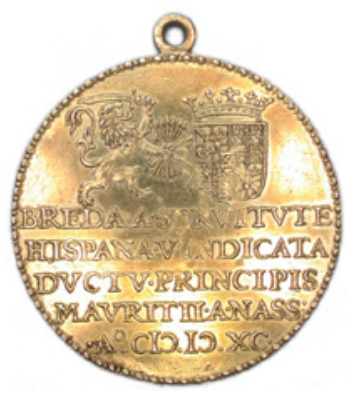

Fig. 4b. Back.

the market square, proof of the importance which the magistrate of Breda now attributed to the events of $1590 .^{18}$

Another reminder of the episode of the peat barge was the new governor of the city. Charles de Heraugière, the captain of the soldiers in the barge, had been appointed as governor of Breda in $1590 .{ }^{19}$ To celebrate his arrival, the city presented him with a silver dish and two bottles. ${ }^{20}$ These gifts were an important gesture by the magistrate to show their appreciation of the new urban regime. This act was especially relevant, because although the magistrate had changed since 4 March, a number

18 Poppo van Burmania, Enege gedenckwerdege geschiedenissen. Kroniek van de Friese militair Poppo van Burmania uit de Tachtigjarige Oorlog, ed. Wiebe Bergsma (Hilversum: Verloren, 2012), 92.

19 Meeuwissen, '... de onderste turven levendich', 36.

20 Grosfeld, 1590-1990, 109. 
of prominent citizens had been allowed to retain their posts, even though they had previously served the enemy. Therefore, it was necessary for them to demonstrate their loyalty to the new regime. ${ }^{21}$ Another example of such a gift was the 'coupe-tasse' commissioned for Count Philips von Hohenlohe, who had led the States' army outside Breda's gates. Because he had excused the city from paying him his reward of two months' wages, the magistrate of Breda decided in 1600 to present him with a large drinking goblet on which a detailed account of the attack including the roles played by Von Hohenlohe and the magistrates was depicted. ${ }^{22}$ The commission, executed by silversmith Marcus Elias of Breda, cost over 1000 guilders. The goblet shows the magistrates holding their hats in their hands while negotiating the future of their city after the army captured the castle. This reference to the humble position of the magistrate after 1590 was another sign of newly found loyalty. The message of the goblet therefore focused primarily on the prosperous future Breda could expect now that it had come under the control of the Republic. ${ }^{23}$

\section{Appropriating the Peat Barge}

In addition to showering participants with gifts and embracing the attack by putting the barge on display in the centre of Breda the new magistrate also started to celebrate the victory annually on 4 March. In 1616, a play written by poet Jacob Duym in 1606 was performed for this occasion. ${ }^{24}$ Even when Breda was besieged by the Spanish Army in 1624, the city still celebrated the anniversary of the return to the prince of Orange in 1590 with cannon fire. ${ }^{25}$ In 1610 a new place of memory relating to the attack was created when a freshly dug part of Breda's waterway was given the name Spanjaardsgat or 'Spaniard's gap' in reference to the breach in the Spanish

21 After 1590 the magistrate in Breda consisted of Reformed citizens, but Catholic members of the urban elite were still included. These magistrates opted for a moderate political course. See Simon Groenveld, 'Een notabele frontiere. Breda en zijn regenten in het spanningsveld tussen noord en zuid, 1576-1610', De Oranjeboom 43 (1990), 16-39, there 26, 31-32; Immerseel, Breda 1568-160o, 67, 81 .

22 Grosfeld, 1590-1990, 109; Meeuwissen, ‘... de onderste turven levendich', 29-34.

23 Meeuwissen, '... de onderste turven levendich', 29-34; Kees Zandvliet (ed.), Maurits, Prins van Oranje (Amsterdam: Waanders, 2000), 271.

24 Meeuwissen, '... de onderste turven levendich', 38.

25 Eimermann, 'De Breda obsessa', 123-124. 
defence during the 1590 attack. ${ }^{26}$ The magistrate of Breda thus successfully appropriated the attack of 1590 by actively creating a memory landscape inside the city walls. The barge and the celebrations could be visited freely by citizens and tourists in Breda.

The soldiers in the barge were very proud of their achievements, but their stories did not normally form part of the local civic memory. For example, young Rochus Rees was painted in 1622 wearing a large, gold medal depicting the peat barge (figure 5). ${ }^{27}$ This medal, which he probably inherited through the female line, served as a symbol of his ancestor's involvement in the attack more than thirty years before. ${ }^{28}$ Others did not have the funds to depict themselves or their descendants wearing the medals, but just passed down the medal itself, and this practice continued for centuries. ${ }^{29}$ Or they requested payment of pensions and other amounts of money in relation to their role in the attack of $1590 .{ }^{30}$ The personal attachment to the attack thus lived on beyond Breda, which ensured that the story stayed alive across the Low Countries.

Within Breda there were few people who could tell personal stories associated with the attack, but one man in particular kept his personal memories of the peat barge alive: Captain Charles de Heraugière. This nobleman from Cambrai had served in the States army for many years, but his reputation had been compromised by his involvement in the plans of the earl of Leicester in $1587-88 .{ }^{31}$ Therefore, his position as captain of the peat barge offered an opportunity to clear his name. After the successful completion of his mission De Heraugière was named governor of Breda and given a medal and several pieces of silver. He was so proud of his achievements that he also commissioned two objects to commemorate his part in the events of 1590: a painting (figure 6) and a silver table piece.

26 Th. Roest van Limburg, Het kasteel van Breda. Aanteekeningen betreffende het voormalig Prinsenhof te Breda (Schiedam: Roelants, 1904); Pieter Nuyts, De Bredaasche Klio (Amsterdam, 1697).

27 Anonymous, Kinderportret, 1622, oil on panel, Dordrechts Museum.

28 The list of soldiers does not include the name 'Rees'. 'Krijgsvolk in het turfschip van Breda 1590', De Navorscher 13 (1883), 170-171.

29 Testament Sijloo family, Gemeentearchief Rotterdam (GAR), Notariële akten, Delfshaven, 3865 number 32 (1704) and 3878 number 125 (1723).

30 See for example 24 November 1608, 8 June 1612, 6 May 1620 and 5 March 1622, Resolutiën der Staten-Generaal Oude en Nieuwe Reeks 1576-1625, 7 vols. (Den Haag: Nijhoff, 1915-1994), 331 (1608), 667 (1612), 456 (1620) and 426 (1622).

31 John Lothrop Motley, History of the United Netherlands: from the death of William the Silent to the Twelve Years' Truce 3 (1590-1600) (Reproduction 1867 edition, Cambridge University Press: Cambridge, 2011), 7. 


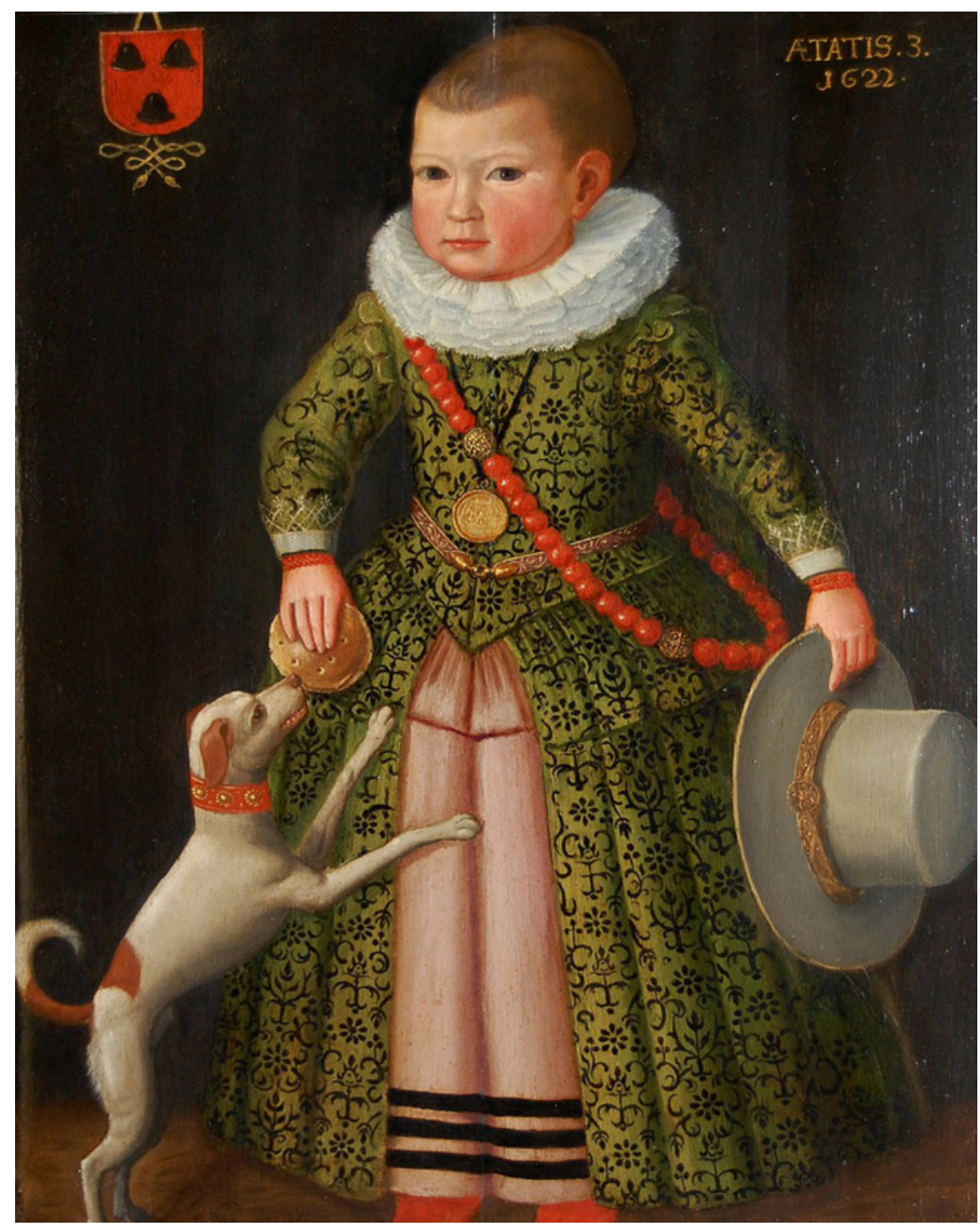

Fig. 5. Anonymous, portrait of Rochus Rees, 1622, oil on panel, Museum Huis van Gijn, Dordrecht. 


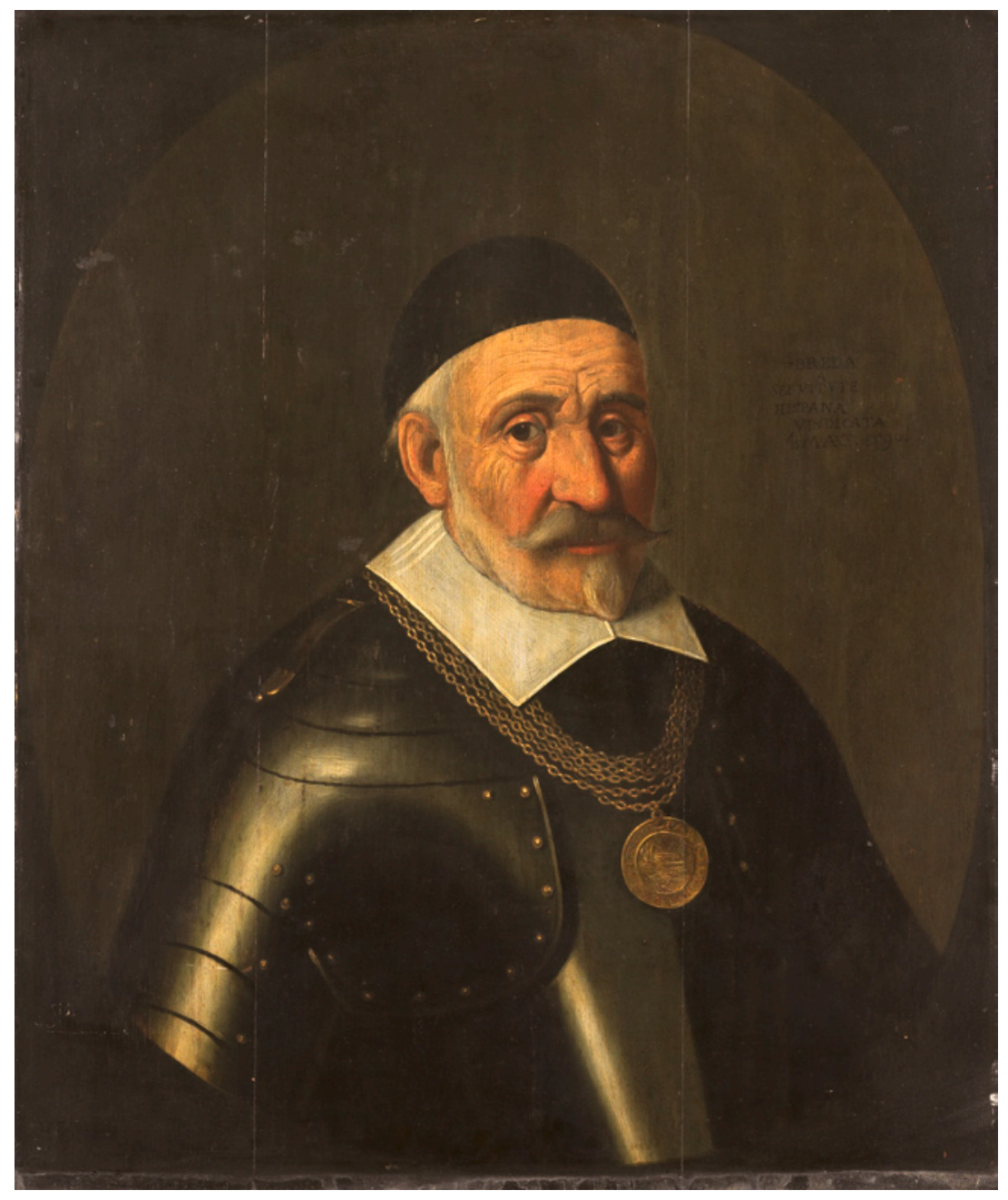

Fig. 6. Anonymous, Charles de Heraugières (1556-1601), after 1590, oil on panel, Rijksmuseum Amsterdam. 
De Heraugière's portrait depicted the captain of the barge, proudly wearing his medal. A Latin text was positioned beside his head, explaining the events of 1590 . Although it is not clear whether he commissioned the painting himself, it conveyed the same triumphant message as the depiction of Rochus Rees. ${ }^{32}$ The second piece De Heraugière commissioned was a spectacular commemorative object: a small silver peat barge. He wanted to create a 'memory of the capture of the castle and city of Breda by way of a peat barge' and for this memory he was willing to spend 900 guilders. ${ }^{33}$ After the governor's death, his widow offered the ship to the States General in 1611, and since it represented such an important event the States bought the object from her. ${ }^{34}$ What had once started as a personal memory of the peat barge now became part of its national memory culture. But while States General bought the ship to prevent it from being melted or sold to someone who did not appreciate its commemorative value, they did not, apparently, think it was essential for them to keep the ship. When Charles de Heraugière's son petitioned the States General to return the ship to him in 1621 , he received the silverware on the promise that he would not sell or pawn it without their consent. ${ }^{35}$

Although this meant that the silver barge disappeared from the public domain, the short period in possession of the States General points to the continuous appreciation for the memory of the peat barge. It is also significant that De Heraugière's widow turned to the States General with her request instead of to the magistrate of Breda. Even though public commemoration had been appropriated on an urban level, his widow appealed to the States General, either because she thought she would receive a better price or because she wanted to emphasise her husband's importance during the Revolt and wanted to think of the episode of the peat barge as a national rather than as a local event.

\section{The Peat Barge Destroyed. The Siege of 1625}

The national value of the peat barge had been emphasised since 1590. In songs, plays, news tidings and prints about the attack the skipper, Captain

\footnotetext{
32 Anonymous, Charles de Heraugières (1556-1601), after 1590, oil on panel, Rijksmuseum Amsterdam, SK-A-575.

33 S. Muller, 'Een zilveren turfschip van Breda', Oud Holland 32 (1914), 72.

34 Ibid.

35 Resolutiën der Staten-Generaal. Nieuwe Reeks 1610-1670 5 (1621-1622), ed. J. Roelevink (The Hague: Martinus Nijhoff, 1983), 370.
} 
De Heraugière or Maurice were celebrated as the heroes of the peat barge without referring to Breda as much more than the place of action. ${ }^{36}$ The role of Stadholder Maurice was commemorated especially after his series of military victories in the 1590 os and in the prelude to the Twelve Years Truce (1609-1621). In 1601 a new Nassau genealogy was published which featured Maurice's victories such as the peat barge attack in prints. ${ }^{37}$ In 1606 Jacob Duym wrote six plays to commemorate the Spanish cruelties and Dutch victories including one relating to the events in Breda in 1590. Duym, as a member of the anti-peace faction in Dutch politics, emphasised Maurice's successes to convince the peace faction that new victories would and could be achieved. ${ }^{38}$ And in 1614 the city of Amsterdam chose to honour the 1590 s victories by commissioning a silver dish depicting these military triumphs. ${ }^{39}$ Thus we find the history of the peat barge being widely used in national propaganda at the beginning of the seventeenth century.

Yet while the Dutch Republic celebrated its heroes in the period after 1590, in 1621 at the end of the Twelve Years Truce in the war between the Republic and its Habsburg foes, conflict returned to Breda. The strategic and military importance of the city made it one of the most important targets for the Spanish army, and in 1624 the Habsburg commander Ambrogio Spinola therefore commenced a long siege. Prince Maurice tried to lure the Habsburg troops away from Breda but failed in this attempt. On 23 April 1625, several months before the siege was decided in favour of Spinola, the stadholder died. On 2 June 1625 the capitulation treaty was signed by the magistrate of Breda, and on 5 June the Spanish victors entered the city. ${ }^{40}$

The loss of the strategic city of Breda made a great impression in the Dutch Republic and the Habsburg Netherlands. In the Republic, the loss was considered a personal defeat for the new stadholder, Frederick Henry, who, with the city, lost his family's barony, while the States General also

36 'Een nyeu Liedeken vant innemen van Breeda', in E.T. Kuiper and P. Leendertz (eds.), Het Geuzenliedboek (Zutphen: W.J. Thieme, 1924), 21-25; Duinkerken, 'Het Turfschip van Breda', 17, 22; Klinkert, Nassau in het nieuws, 75-77.

37 See for example, Bartolomeus Dolendo, Inname van Breda 1590, 1597-1601, engraving, Rijksmuseum Amsterdam, RP-P-OB-80.089; Klinkert, Nassau in het nieuws, 76-77.

38 Meijer Drees, 'Liever een rechtvaardige oorlog', 1-4, 11.

39 Adam van Vianen, Schaal met veld- en zeeslagen uit de Tachtigjarige Oorlog, 1614, metal, Rijksmuseum Amsterdam, BK-AM-17-A. See also Klinkert, Nassau in het nieuws, 82.

40 V.A.M. Beermann et al. (eds.), Geschiedenis van Breda 2. Aspecten van de stedelijke historie, 1568-1795 (Schiedam: Interbook International, 1977), 55-56; Groenveld, 'Breda is den Bosch waerd', 98-100. 
lost control over a large part of western Brabant. ${ }^{41}$ For the Habsburg Netherlands and Spain, however, Spinola both avenged the humiliating attack with the peat barge and recaptured a strategic city in the northern Netherlands. In the celebrations that followed the end of the siege, Spinola ordered the destruction of all evidence of the peat barge attack, including archival records and the old barge that still stood in the city centre to commemorate the attack. ${ }^{42}$ In the days following the siege, 'the ship... that had transported the pious Trojans' was burned. ${ }^{43}$

The burning of the barge also returned in popular Habsburg imagery following the siege of 1625 . For example, Paulus Pontius made an engraving after a portrait of Archduchess Isabella in 1625 in which he incorporated the rudder of the peat barge in the cornice to emphasise her role as conqueror of Breda. ${ }^{44}$ Another engraving, published in Antwerp, depicted a fictitious funeral procession of the Dutch regime leaving Breda with the peat barge in the middle foreground (figure 7). In the dialogue below the illustration the peat barge is described

And there underneath the roof the peat barge which was preserved to commemorate that thirty five years ago it endangered the city, in this triumph comes in usefully to make a merry fire..$^{45}$

Frisian nobleman and soldier Poppo of Burmania noted that

As soon as they entered with their garrison, the Spaniards chopped the peat barge, by which the city was captured before, to pieces, since it stood on display on the market [square].46

Both sources remark on the fact that the barge had been a successful object of memory for Breda. The efforts of the magistrate of Breda to create a memory culture of the peat barge and to appropriate the attack as the story of the city had therefore been effective. The barge, which was the

41 Zandvliet, Maurits, 222.

42 Y.P.W. van der Werff, 'Rond het Turfschip', De Oranjeboom 11 (1958), 96-104, there 99-100.

43 Nicolaes van Wassenaer, Historisch verhael alder ghedenck-weerdichste geschiedenissen die hier en daer in Europa 3 (Amsterdam, 1626), 85. See also Constantijn Huygens, De gedichten van Constantijn Huygens, ed. J.A. Worp, 3 vols. (1636-1644) (Groningen: Wolters, 1893), 36; Duinkerken, 'Het Turfschip van Breda', 36.

44 Paulus Pontius, D. Isabella Clara Eugenia, Hispaniarum Infans etc., 1626, engraving, British Museum, Rıb.141; Beermann, Geschiedenis van Breda, 406.

45 Anonymous, Treurfeest der Calvinisten, 1625, print, Rijksmuseum, Amsterdam, inventory number 19590019 .

46 Burmania, Enege gedenckwerdege geschiedenissen, 92. 


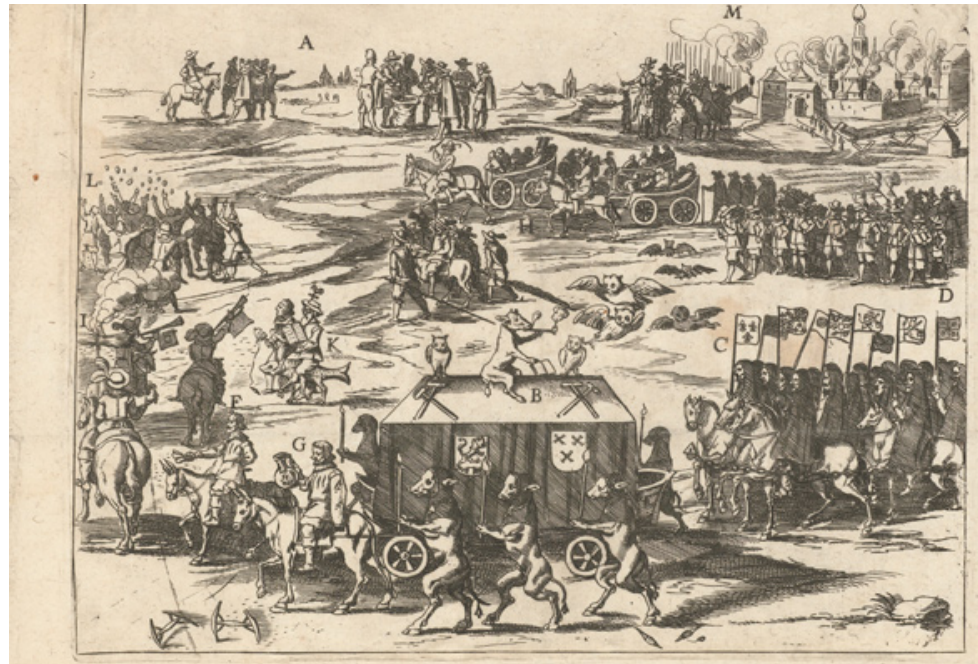

TRE V R.F E E T D E R C A L V I N IST E N, MIDTSGAEDERS DE VVT.VAERT VAN BREDA.

T'famen-fprekinghe tuffchen eenen Brabander, ende Hollander.

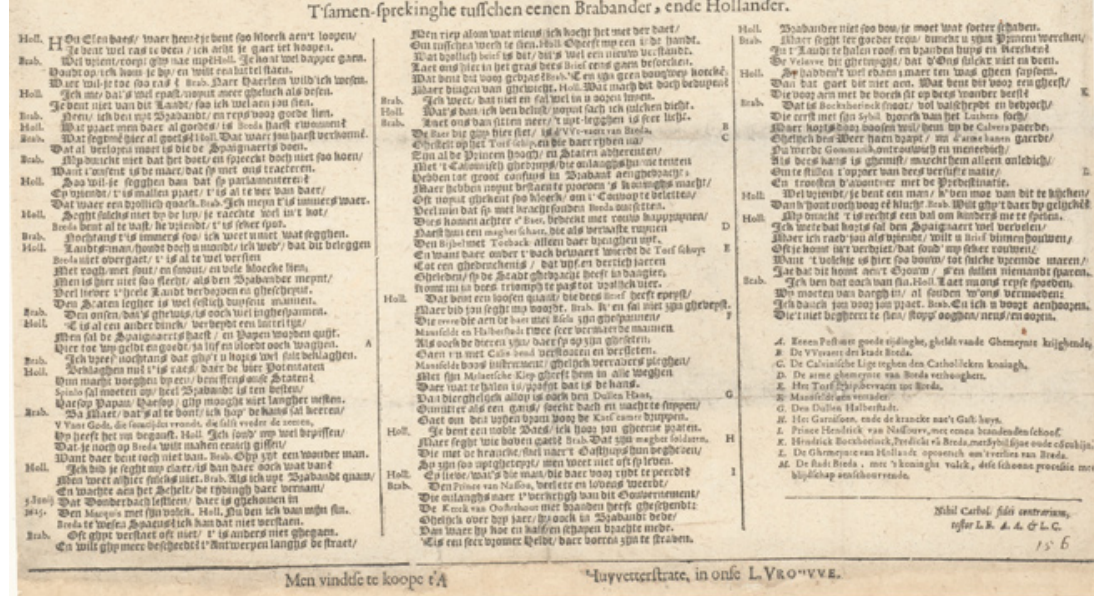

Fig. 7. Anonymous, Treur-feest der Calvinisten, midtsgaeders de wt-vaertvan Breda, 1625, etching, Rijksmuseum Amsterdam. 
most important relic of the events of 1590, had become part of the urban memory landscape. The peat barge, prominently on display in the city centre, had been the symbol of the Calvinist submission of Breda, and as such was now subjected to ritual destruction. ${ }^{47}$

Spinola's attempts to erase the traces of the humiliating defeat were temporarily successful. Moreover, as the Dutch had done before him in 1590, the Habsburg capture of Breda in 1625 also became the subject of national propaganda. The government in the Habsburg Netherlands commissioned medals and a map to commemorate the event. ${ }^{48}$ In Spain, the siege became one of the Habsburg successes which became very popular in the 1630 s and which were cited as a source of future inspiration. Its most famous representation, by Diego Velázquez, retains its renown. ${ }^{49}$ For Breda, however, the period between 1625 and 1637 proved to be only an interruption in Dutch rule. For the Spanish army the siege of 1625 had been a costly affair. Shortly afterwards, stadholder Frederick Henry conquered important cities in the border regions of the Dutch Republic, including Grol in 1627, 's-Hertogenbosch in 1629, and Maastricht in 1632, before finally recapturing Breda in October $1637 .{ }^{50}$ The city could now re-embark on creating a memory culture as once again a part of the Dutch Republic.

\section{The Return of the Peat Barge}

Through his strategic victory in Breda in 1637, Frederick Henry had recaptured his family's seat, avenged the loss of the city in 1625 and achieved greater security for the key province of Holland. ${ }^{51}$ After his victory Frederick Henry did not visit the city. Although he ordered that an annual celebration should be organised on 10 October, the day the Dutch army entered the city, this decree was never observed. ${ }^{52}$ Neither did the siege of

\footnotetext{
47 Grosfeld, 1590-1990, 37, 104.

48 See for example, Noordbrabants Museum, Collection, Inventory numbers 03663, 04530.2 and 04530.3; Zandvliet, Maurits, 224-416.

49 For example, Diego Velazquez, the surrender of Breda, 1635, oil on canvas, Prado Madrid; Zandvliet, Maurits, 417; Vosters, Het beleg en de overgave van Breda, 205-208.

50 Groenveld, 'Breda is den Bosch waerd', 101-109; J.W.M. Schulten, 'Het beleg van Breda in 1637', De Oranjeboom 41 (1988), 156-167, there 161; W. Klinkert, 'Het beleg verslagen. Ooggetuigen, tijdgenoten en historieschrijvers over het beleg van Breda in 1637', De Oranjeboom 41 (1988), 110-123, there 110-112.

51 Groenveld, 'Breda is den Bosch waerd', 101-109; Schulten, 'Het beleg van Breda', 161; Klinkert, 'Het beleg verslagen', 110-112.

52 Schulten, 'Het beleg van Breda', 164-166.
} 
1637 ever reach the same standing in seventeenth-century histories as the sixteenth-century sieges of Leiden and Alkmaar or Frederick Henry's 1629 victory at 's-Hertogenbosch. Even the official date of surrender, 8 October, coincided with the relief of Alkmaar, which was still considered more significant than the siege of Breda. ${ }^{53}$

From a national perspective, however, the siege of 1637 nevertheless received ample attention, sometimes in combination with a reminder of the peat barge episode. The States General immediately commissioned a medal to celebrate the surrender of Breda in both 1590 and 1637 (figure 8). The peatbarge is displayed on the left while on the right the starving patroness of Breda represents the siege of 1625 . In the middle a harnessed arm appears from the sky, referring to Divine Providence and the way Frederick Henry won his victory in 1637. This reading of the imagery is confirmed by the caption which states: 'In the past the road was cleared by starvation or cunning, yet now by force. ${ }^{54}$

Despite pointing to the different ways in which the city had been conquered in the past, the connection between 1590 and 1637 was made obvious. As in 1590, the significance of the siege of 1637 went beyond Breda. Like Maurice, Frederick Henry was praised for his role in the victory, and the event became national news. ${ }^{55}$ The siege of 1637 was also painted many more times than the peat barge attack, and depictions of the event could be found hanging in private homes in the Low Countries in the ${ }_{1640 s .}{ }^{56}$ Later in the seventeenth century, after the Peace of Westphalia in 1648 , the topic continued to remain popular. ${ }^{57}$

In due course, there emerged a local and personal memory culture after 1637. Yet, the sources reveal that 1637 was more frequently described by authors from outside the city than by those from Breda. ${ }^{58}$ Although indi-

53 Ibid., 118-119.

54 Johannes Looff, Breda heroverd door Frederik Hendrik, 1638, silver, Noordbrabants Museum, 's-Hertogenbosch, inventory numbers 03679. This is one of two medals issued to commemorate the victory of Frederik Henrik; the other does not contain references to earlier sieges, inventory number 03680 .

55 Boxhorn, Geschiedenis van het beleg; Klinkert, 'Het beleg verslagen', 118.

56 The Frick Collection, Montias Database, inventory numbers 174.0013. 369.0017, 432.0019, 464.0067, only one painting is known of the peat barge inventory number 12160.0037 via http://research.frick.org consulted 7 November 2012.

57 For example, Hendrick de Meijer, De uittocht van de Spaanse besetting van Breda, 1647-1683, oil on panel, Rijksmuseum Amsterdam, SK-A-1511; Abraham van Calraet, Officieren en dorpelingen bij een kamp buiten Breda, 1670-1680, Paleis 't Loo, Apeldoorn; Abraham van Calraet, Frederik Hendrik bij het beleg van Breda, ca. 1680, Paleis 't Loo, Apeldoorn.

58 Schulten, 'Het beleg van Breda'; Klinkert, 'Het beleg verslagen'. 


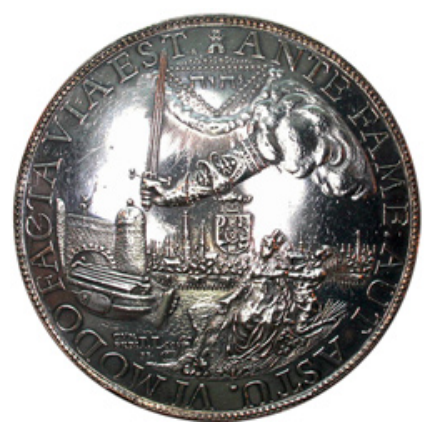

Fig. 8a. Johannes Looff, commemorative medal, Breda recaptured by Frederick Henry, 1638, silver, Noordbrabantsmuseum 's-Hertogenbosch, front.

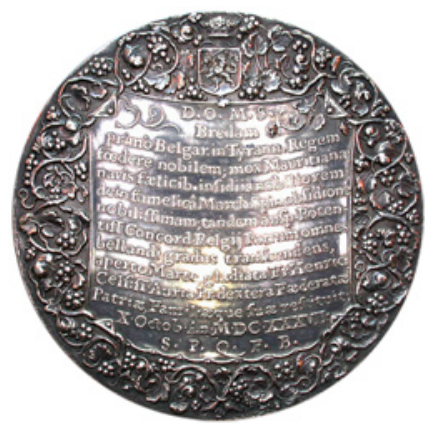

Fig. 8b. Idem, back.

vidual memory practices of 1637 may have existed, public commemorations in Breda seem to have focused almost entirely on the restoration of the peat barge. The continued importance of the barge had been expressed by the States' reference to the attack in the medal. Of course, the magistrate organised a service to commemorate the siege, but the peat barge soon elbowed more recent memories into second place. ${ }^{59}$ Even the most challenging obstacle to the renewed commemoration of the attack of 1590, the fact that the barge had been burned, was solved. After 1637 the rudder of the barge, which had been displayed on the print of Isabella in 1625 , resurfaced in Breda and was put on display again. ${ }^{60}$

59 Schulten, 'Het beleg van Breda', 164-166.

60 G.C. Postma, 'Met een Statencommissie op reis naar Brabant in 1767', Handelingen van het Provinciaal Genootschap van Kunsten en Wetenschappen in Noord-Brabant (1943), 74. 
And so the 'remains' of the peat barge, as Englishman Edward Brown described them in 1682 , remained a prominent feature in the centre of Breda. ${ }^{61}$ Not only the rudder, but other memorials were put in place by the magistrate to commemorate the events of 1590 . In 1744, local historian Thomas van Goor recounted that

One still sees today on the east side of that canal, near the back-court of the castle, some blue stones protrude from the wall, as a memorial, so people say, that the peat barge has lain at that place ${ }^{62}$

Moreover, the city displayed its pride over its 'Trojan horse' when government officials visited the city. In 1767 , when the States Committee visited Breda they saw that

at the rear [of the castle] 12 great and protruding stones have been placed, to commemorate the peat barge by which Prince Maurice captured the city in the year 1590; these stones that measure 60 feet at a rough estimate denote the length of an average ship, which has been burned in the year 1625 when the Spanish captured the city again by treaty, yet the rudder is still to be found in a warehouse beside the castle, being kept there in remembrance. ${ }^{63}$

Through the display of the rudder, the stones in the castle and commemorative poems on the centenary of the barge in 169o, the city of Breda continued to associate itself with the peat barge. ${ }^{64}$ Despite the potential of the stories of the siege of 1637 , the magistrates chose to emphasise the heroic capture of the city in 1590.

\section{Conclusion}

The cunning capture of Breda with a peat barge in $159^{\circ}$ placed the city at the heart of the military history of the Dutch Republic. Stadholder Maurice's taking of the strategic city that was also his family's seat was celebrated on a national level as the new Trojan horse. Moreover, it marked the beginning of a series of military successes in the 1590s. For Breda, however, the connection to national history proved tenuous because the city's population did not share in the personal memories of the soldiers who were

61 Edward Brown, Naukeurige en gedenkwaardige reysen van Edward Brown (Amsterdam, 1682), 34 .

62 Thomas van Goor, Beschryving der stadt en lande van Breda (Breda, 1744), 63.

63 Postma, 'Met een Statencommissie', 74.

64 Diana Giesbergen, 'Het Turfschip van Breda', Meertens Insitituut, Nederlandse Volksverhalenbank, via verhalenbank.nl, consulted 30 October 2012. 
involved in the attack. With the exception of the new governor Charles de Heraugière these soldiers had moved on and taken their stories and mementos of the attack home with them. This meant that even though the story of the peat barge spread throughout the Low Countries, Breda itself featured only as the place of action.

The new magistrate of Breda nevertheless immediately made the decision to appropriate the attack. In this process the acquisition of the actual barge was a crucial element. The barge was put on display in the market square, plays were performed, and an annual celebration was established. After 1590 the barge became the symbol of the attack, and the centre of Breda's memory landscape. This changed when the barge was burned by Spanish army commander Spinola after he recaptured the city in 1625 . Yet, the symbolic function of the barge was also confirmed in this action. The relic had become such an important part of the memories of the attack, that it needed to be destroyed. Moreover, in 1637 when Stadholder Frederick Henry secured the city for the Dutch Republic the symbol returned when the barge's rudder reappeared. Once again the barge took centre stage in the memory culture of Breda. Breda's sieges of 1625 and 1637 were commemorated on a national rather than a local level. Yet even there, the memories of the two other sieges did not displace the events of 1590 but rather emphasised the significance of the peat barge.

By examining the full range of commemorative objects and artefacts associated with the capture of Breda in the long term and comparing them with both texts and the memory culture after the sieges of 1625 and 1637, one can make some more general points. Early modern local memory cultures did not arise as a matter of course. They were the result of the actions of significant stakeholders. In some Dutch cities, those stakeholders included people of all ranks, who both added to and appropriated commemorative practices initiated by the authorities. In Breda, it was mostly the magistrates who took charge of the memory culture. Yet that is not to say that memory culture was limited to elite circles only. Although few of Breda's citizens had access to the traditional elite media such as paintings and silver, every citizen could participate in singing songs, attending plays or beholding the peat barge on display on the market square. Once we are aware of the enormous range of media being used for commemorative purposes and of the strong intermediality between them, it becomes possible to appreciate that even before the age of mass media, it was possible for the urban landscape to be saturated with significant memories, visible and understandable to all. 
Erika Kuijpers, Judith Pollmann, Johannes Müller, and Jasper van der Steen - 978-90-04-26125-9 Downloaded from Brill.com04/26/2023 11:57:20AM via free access 


\title{
'THE ODIOUS DEMON FROM ACROSS THE SEA'. OLIVER CROMWELL, MEMORY AND THE DISLOCATIONS OF IRELAND
}

\author{
Sarah Covington
}

As with any country subject to colonisation, partition, and dispossession, Ireland harbours a long social memory containing many villains, though none so overwhelmingly enduring — indeed, so historically overriding — as Oliver Cromwell. Invading the country in 1649 with his New Model Army in order to reassert control over an ongoing Catholic rebellion-turned royalist threat, Cromwell was in charge when thousands were killed during the storming of the towns of Drogheda and Wexford, before he proceeded on to a sometimes-brutal campaign in which the rest of the country was eventually subdued, despite considerable resistance in the next few years. Though Cromwell would himself depart Ireland after forty weeks, turning command over to his lieutenant Henry Ireton in the spring of 1650, the fruits of his efforts in Ireland resulted in famine, plague, the violence of continued guerrilla war, ethnic cleansing, and deportation; hundreds of thousands died from the war and its aftermath, and all would be affected by a settlement that would, in the words of one recent historian, bring about 'the most epic and monumental transformation of Irish life, property, and landscape that the island had ever known'. ${ }^{1}$

Though Cromwell's invasion generated a significant amount of international press and attention at the time, ${ }^{2}$ scholars have argued that Cromwell as an embodiment of English violence and perfidy is a relatively recent phenomenon in Irish historical memory, having emerged only as the result of nineteenth-century nationalist (or unionist) movements which

1 William J. Smyth, Map-making, landscapes, and memory. A geography of colonial and early modern Ireland, $1530-1750$ (Notre Dame: University of Notre Dame Press in association with Field Day, 2006), 196. For a more recent treatment of Cromwell, see Micheál Ó Siochrú, God's executioner. Oliver Cromwell and the conquest of Ireland (London: Faber \& Faber, 2008).

2 Michaél Ó Siochrú, 'Propaganda, rumour and myth. Oliver Cromwell and the massacre at Drogheda', in David Edwards, Pádraig Lenihan and Clodagh Tait (eds.), Age of atrocity. Violence and political conflict in Ireland, $1550-1650$ (Dublin and Portland: Four Court Press, 2007), 266-282. 
constructed traditions or shaped memories around him in order to justify their respective causes. As Toby Barnard has written, Irish histories of the later seventeenth century tended in their royalist concerns to overlook the Cromwellian interregnum, while the heroic symbol of the Protestant ascendancy rested not in Cromwell but William III, 'a man not without [his own] embarrassing blemishes, but altogether less dangerous than Cromwell'. If anyone was to be the great enemy, it was the Protestant James Butler, the duke of Ormonde, or on a lesser level Murrough O'Brien, Lord Inchiquin, who recovered their estates during the restoration of Charles II and, in the former's case, oversaw new or existing land transfers into the hands of a Protestant minority. ${ }^{3}$ Meanwhile, the eighteenth century, while rich in Irish historical and literary activity, witnessed Catholic and Protestant histories that focused not on 1649 or the 1650 , but on the rising of 1641, the Restoration, and the Williamite settlements, with Cromwellaccording to Barnard-presented as an honourable enemy rather than a 'duplicitous fiend'. It was not until the works of J.P. Pendergast and W.E.H. Lecky, both Victorians, that a darker Cromwell came forth, with Lecky writing that Drogheda and Wexford and the subsequent resettlements 'made the name of Cromwell eternally hated in Ireland', leading to the deep and sustaining antipathy 'both of England and of Protestantism'. ${ }^{4}$

Lecky's remark that Cromwell had been 'eternally hated' reveals, however, that the calamitous legacy of the conqueror was very much remembered, and demonised, long before nineteenth-century partisan historians or folklorists discovered his use as an effective villain. For the previous two centuries Cromwell had already appeared in a variety of forms across oral

3 See Coleman A. Dennehy, Restoration Ireland. Always settling and never settled (Aldershot and Burlington: VT: Ashgate, 2008), 167ff. For Ormonde's reputation, see Éamon Ó Ciardha, 'The unkind deserter' and 'the bright duke'. Contrasting views of the dukes of Ormonde in the Irish royalist tradition', in Toby C. Barnard and Jane Fenlon (eds.), The dukes of Ormonde. 1610-1745 (Woodbridge: Boydell Press, 2000), 177-194.

4 For memory and 1641, see Ireland: 1641: Contexts and Reactions, ed. Micheal O Siochru and Jane Ohlmeyer (Manchester: Manchester University Press, 2013); John Gibney, The Shadow of a Year: The 1641 Rebellion in Irish History and Memory (Madison, WI: University of Wisconsin Press, 2013). Toby C. Barnard, 'Irish images of Cromwell', in Roger C. Richardson (ed.) Images of Cromwell (Manchester: Manchester University Press, 1993), 180-206; Jason McElligott, 'Cromwell, Drogheda, and the abuse of Irish history', Bullán. An Irish Studies Review 6:1 (2001), 109-132. McElligott takes issue with Barnard's sole focus on the histories of literate Irish elites as well as his failure to explore the oral or folkloric tradition; rather than trace this other tradition back in time, however, McElligott himself cites only a few nineteenth-century folklorists, thus implying that the Cromwell of enduring and hated memory, in other words, did not truly become a presence as such until elite historians, writers of textbooks, and professional folklore anthologists deemed him so. See also William E.H. Lecky, A history of Ireland in the eighteenth century (London: Longmans, Green \& Co, 1906), vol. 1, 101. 
and popular culture, in response to an experience of deep rupture that he had effected in Irish history. Yet these earlier memories-contained in poetry, folklore, or popular religion-resist modern expectations of what collective memory (or for that matter, history) is to be since they play loose with historical details or avoid psychological accounts of the 'traumatic', particularly if that term is taken in its modern sense as a sudden, violent, accidental and contingent intrusion of the 'meaningless' onto existing frames of thought. ${ }^{5}$ In the years immediately following the conquest, for example, martyrologies, sermons, and eyewitness letters told of priests being summarily executed by Cromwell's men, which was true enough, though such accounts also described the killing of 'virgins', thus connecting the massacres to the virgin martyr legends from centuries before; ${ }^{6}$ religious folklore of the seventeenth century onward echoed these stories, which also described resistance in the form of monks hiding treasures from Cromwell's invading men or fleeing their monasteries with their books - which also surely occurred, even though the reference also directly echoed older stories related to medieval Irish monastic traditions. More than simply chronicles or victimologies of the deaths occurring under Cromwell, these stories were thus memorialisations of catastrophe assigned to transcendental or providential categories, which occurred in a distinctly pre-modern, enchanted world.

Though their work is imbued in already existing literary conventions, poets such as Brian Mac Giolla Phádraig (d. 1652) or Aogán Ó Rathaille (d. 1729) for their part lamented the world lost under Cromwell and the conquerors before and after him, with Mac Giolla Phádraig-as a priest, executed by Cromwell's men in 1652 - writing, 'A trick of this false world has laid me low: servants in every home with grimy English but no regard for one of the poet class save "Out! and take your precious Gaelic with you!" '7 But an altogether different Cromwell also appeared as a character in folkloric mummers plays, beginning in the late seventeenth and early

5 See Cathy Caruth, Unclaimed experience. Trauma, narrative and history (Baltimore and London: Johns Hopkins University Press, 1996); see also Shoshana Felman and Dori Laub, Testimony. Crises of witnessing in literature, psychoanalysis and history (London and New York: Routledge, 1992).

6 Patrick Corish and Benignus Millet (eds.), The Irish martyrs (Dublin: Four Courts Press, 2004), esp. 181-201; Clodagh Tait, 'Adored for saints. Catholic martyrdom in Ireland c. 1560-1655', Journal of Early Modern History 5 (2001), 128-159.

7 See Tom J. Dunne, 'The Gaelic response to conquest and colonisation. The evidence of the poetry', Studia Hibernia 20 (1980), 7-30; Nicholas Canny, 'The formation of the Irish mind. Religion, politics, and Gaelic Irish literature, 1580-1750', Past and Present 95 (1982), 91-116. 
eighteenth centuries, with his large copper nose and his boastful nonsense ('Here comes I, Sir Oliver Cromwell, With my large and copper nose. I made the Frenchman for to tremble, and the Germans for to quake, I bet the jolly Dutchman coming home from the wake'). ${ }^{8}$ Both the mumming genre and the nose - a universally significant motif in folklore-had migrated over from England, after gaining popular currency in depictions by royalist polemicists and satirists; for all the violence of the civil wars in England, however, Cromwell carried a different history in Ireland, which made the Irish mumming of Cromwell noteworthy in being denuded of all biographical detail, and rendered peripheral and utterly powerless in the legendary pantheon of other mumming characters such as Beelzebub (Cromwell's partner) or St Patrick. ${ }^{9}$ But a darker kind of diabolism was also at work in yet other migratory tales, which told of Cromwell training his men under the flag of the devil, or sealing various pacts with Satan, or serving as a bogeyman, or as the instigator of a curse or insult ('the curse of Cromwell on you'). ${ }^{10}$ The memorialisations of Cromwell were therefore not simply diverse, but multimedial and multidirectional, extending across oral and print expressions, high and low culture, regions and countries, the archaic world before and its modern aftermath.

Nowhere was Cromwell memorialised more insistently, however, than in the very land that he affected through his policies of confiscation, expulsion, and re-settlement. ${ }^{11}$ Landscape had always functioned as

8 For a recent and incisive treatment of the mummers and folk drama around the world, see Steve Tillis, Rethinking folk drama (Westport, CT and London: Greenwood, 1999); see also Alex Helm, The English mummers' play (London: Brewer for the Folklore Society, 1981); for traditional and more recent approaches to the performance in Ireland and England, see for example Alan Gailey, Irish folk drama (Cork: Mercier Press, 1969); Reginald J.E. Tiddy, The mummers' play (Oxford: Clarendon Press, 1923); Alan Brody, The English mummers and their plays. Traces of ancient mystery (Philadelphia: University of Pennsylvania Press, 1970); Susan Pattison, 'The Antrobus soulcaking play. An alternative approach to the mummers' play', Folk-Life 15 (1977), 5-11; Bryan Jones, 'Christmas mumming in Ireland', Folklore 27 (1916), 301-307; H. Coote Lake, 'Mummers' plays and the 'sacer ludus', Folklore 42 (1931), 141-149; Alan Gailey, 'Chapbook influence on Irish mummers' plays', Folklore 85 (1974), 1-22. See also William Smith Clark, The early Irish stage. The beginnings to 1720 (Oxford: Clarendon Press, 1955), 3-8 and William Smith, The Irish stage in the county towns, 1720 to 1800 (Oxford: Clarendon Press, 1965).

9 Laura Lunger Knoppers, Constructing Cromwell. Ceremony, portrait, and print 1645- $^{-}$ 1661 (Cambridge: Cambrigde University Press, 2000), esp. 11-15, 46-50.

10 For Cromwell and the Irish cursing tradition, see for example William Carleton, Traits and stories of the Irish peasantry, ed. D.J. O'Donoghue (London: J.M. Dent and New York: Macmillan, 1886), 213; for a longer history of the curse, see also Bernard Mees, Celtic curses (Woodbridge: Boydell Press, 2009).

11 See Karl Bottigheimer, English money and Irish land. The adventurers in the Cromwellian settlement of Ireland (Oxford: Clarendon Press, 1971); for Cromwellian governance, 
a mnemonic device in Ireland, beginning with the ancient tradition of dinnseanchas, a kind of story-lore in which features of the landscapetrees, rocks, wells - were imbued with tales of origin, implying, in Seamus Heaney's words, 'a system of reality beyond the visible realities' ${ }^{12}$ This symbiosis between lore and landscape - or, to put it another way, the narrativisation and at times sacralisation of landscape-imbued that landscape with emotion, resulting in what Yi-Fu Tuan has called 'topophilia', or the affective bond between people and their place or setting. ${ }^{13}$ Story telling made this bond possible, since 'narratives [served to] vivify the landscape, transforming it from a neutral piece of territory into a stage set for ever evolving and changing historical events'. Yet as Kent Ryden has written, if 'place enfolds relationships, relationships shape memories, memory sparks stories, [and] stories cling to place with such tenacity', then 'the destruction of place threaten[ed] the entire structure'. ${ }^{14} \mathrm{Crom}$ well's severing of the connection between people and their environment thus threatened to dislocate all the associations and memories contained within that connection; yet as this essay will argue, while Cromwell disrupted that bond, he did not destroy it. Instead, with his presence came a new archaeological layer of narrative that was inscribed onto the landscape, as rocks, wells, and ruins become new 'places of memory', even if those places were now testimonials to the violence and dispossession that he and his soldiers inflicted.

Thousands of stories attest to remembrance of Cromwell in the National Folklore Collection at University College Dublin, an archive of memory that grew out of the National Folklore Commission established in 1935, after decades of folkloric collecting and anthologizing in Ireland. ${ }^{15}$ Containing

see Toby C. Barnard, Cromwellian Ireland. English government and reform in Ireland, 16491660 (Oxford: Oxford University Press, 1975).

12 Seamus Heaney, Preoccupations. Selected prose 1968-1978 (London: Faber \& Faber, 1980), 132. For the role of landscape in memory, see Katharina Schramm, 'Landscapes of violence. Memory and sacred space', History and Memory 23 (2011), 5-22; Christopher Tilley, 'Introduction. Memory, place, landscape and heritage', Journal of Material Culture 11 (2006), 7-32, there 8; Barbara Bender (ed.), Landscapes, politics and perspectives (Providence and Oxford: Berg, 1993); and Barbara Bender and Margot Winer (eds.), Contested landscapes. Movement, exile and place (New Yorkand Oxford: Berg, 2001).

13 Yi-Fu Tuan, Topophilia. A study of environmental perception, attitudes, and values (Englewood Cliff, N.J., and London: Prentice-Hall, 1974).

14 Kent C. Ryden, Mapping the invisible landscape. Folklore, writing, and the sense of place (Iowa City: University of Iowa Press, 1993), 94.

15 For a description and analysis of the National Folklore Archive and its implications for historical study and memory, see Guy Beiner, Remembering the year of the French. Irish folk history and social memory (Madison, WI, and London: University of Wisconsin Press, 2007), esp. 36-37. 
manuscripts of oral and ethnological material transcribed from interviews and questionnaires in the 1920 s and 1930s, the collection contains many hundreds of references to Cromwell, who ranks second to Daniel O'Connell in the amount of material devoted to him. With the exception of scholars such as Guy Beiner, however, early modern historians have avoided these archives, viewing them not as traces from a deep past but as products that reflect late nineteenth- and early twentieth-century land policy concerns or incipient nationalist sentiments on the eve of a country's independence. For Barnard, many of these folkloric deposits are difficult to locate in time and therefore should be dismissed from historical analysis, constituting as they do a possibly invented tradition rather than evidence of cultural persistence. ${ }^{16}$ Yet too many recurring motifs and tropes connect the transcribed tales to the relatively scanty early modern folkloric evidence for scholars to entirely dismiss those latter-day sources as corrupted products of bias-driven nationalists. Taking into account their inherent distortions, tales written down in the twentieth century can be measured against the more fragmentary evidence of the past, in sources such as sermons, pamphlets, almanacs, early travel accounts, and even tombstones, to recover some evidence of oral attitudes across time. ${ }^{17}$ As Peter Burke has pointed out, if treated cautiously, such stories thus have the potential to reveal the attitudes and mentalities of a past society and as such are able to extend the historical agenda into new and significant directions. ${ }^{18}$ In addition, and particularly in the case of Ireland, folklore, or one could say 'popular' memory, carried the potential to subvert the past and manipulate trauma towards a different, imaginative Irish history, even if the channel to do so was by way of an intentional or unintentional misremembrance of that past, across the early modern and modern periods. ${ }^{19}$

The many iterations of Cromwell in early modern and modern Irish memory lead one to question why he alone merits all the attention in the first place. Cromwell was certainly not the only one to oversee acts

16 Barnard, Cromwellian Ireland, 187.

17 See for example the 1667 tomb in Kilconnell, Galway, of Matthias Barnwell, the 12th Baron of Trimblestown: '... transplanted to Connaught [by] the usurper Cromwell'. (H.V. Morton, In search of Ireland (London: Methuen, 1931)), 62. I wish to thank Kevin Whelan for this reference.

18 Peter Burke, Popular culture in early modern Europe (New York: Harper and Row, 1978), esp. $65^{-87}$.

19 For the usefulness of studying folklore in Irish history, see Beiner, Irish folk history, esp. 17-33. See also Linda Dégh, 'Oral folklore. Folk narrative', in Richard Dorson (ed.) Folklore and folklife. An introduction (Chicago: University of Chicago Press, 1972), 53-83. 
of sometimes shocking violence and radical land reconfigurations, which had begun with the increasingly brutal attempts by the Tudors to suppress rebellion and re-exert control over the land. ${ }^{20}$ The first and second Earl of Essex, Henry Sidney, Lord Grey de Wilton, Lord Mountjoy, Arthur Chichester all preceded Cromwell as agents of this more ruthless colonisation; even in his own time, it would not be defending Cromwell to point out that contemporaries such as Charles Coote or Roger Boyle, Lord Broghill, overtook him in methods of brutality when it came to relations with the Irish. ${ }^{21}$ Cromwell, however, represented the culmination of over one hundred years of Tudor-Stuart conquest, signalling the final defeat of the old Gaelic aristocracy and English-Irish order (his being 'the war that finished Ireland');22 though he represented the last in a continuum of conquest and appealed to previous biblical and providential models, he was also radically modern, not only in the army he brought with him but in the administrative centralisation, planting schemes, utilitarianism, and Protestant ascendancy that came in his wake. Indeed, he had even killed a king. No other English antagonist was therefore so given over to an already-existing and extensive mythmaking process undertaken by admirers, enemies, and, not least, by Cromwell himself; as a result, his persona was adaptable to different frames of narrative and meaning, giving rise to an array of alternative memories that ran parallel or counter to the more conventional histories. Attention to such material is thus important, for as Michel-Rolphe Trouillot has written, we need to be reminded that 'the production of historical narratives involves the uneven contribution of competing groups and individuals who have unequal access to the means of such production'; despite the importance of the official and linear histories, the popular and often contested 'recollections' of more marginal groups are 'no less powerful' in their own contributions to the memorialisations that define a country. ${ }^{23}$

20 See Clodagh Tait, David Edward and Pádraig Leninhan, 'Early modern Ireland. A history of violence', in Edwards, Lenihan and Tait (eds.), The age of atrocity, 9-32.

21 James Scott Wheeler, Cromwell in Ireland (New York: Macmillan, 1999), 5. See also John Morrill, 'The Drogheda massacre in Cromwellian context', in Edwards, Lenihan and Tait (eds.), Age of atrocity, 242-265; Patrick Little, Lord Broghill and the Cromwellian union with Ireland and Scotland (Woodbridge and Rochester, NY: Boydell Press, 2004), 59-90.

22 See the anonymous poem containing the phrase 'an Siogai Romanach' ('the war that finished Ireland'), in James Hardiman (ed.), Irish minstrelsy, or bardic remains of Ireland (London: Robins, 1831), vol. 2, 306-388.

23 Michel-Rolph Trouillot, Silencing the past. Power and the production of history (Boston: Beacon Press, 1995), xix; Jeffrey K. Olick and Joyce Robbins, 'Social memory studies. 
Memory itself does not recall past events so much as it makes meaning out of them, thereby forging a common identity and affective bonds among closed communities of shared values. ${ }^{24}$ It is therefore not synonymous with history, though the manner in which the landscape was memorialised and narrativised in post-Cromwellian Ireland cannot be fully discussed without a larger understanding of what he actually did to that landscape. Under Cromwell more than any previous ruler or administrator, Ireland's geography, in William Smyth's words, became 'the visible symbol of colonial rule', not only in terms of the confiscation and division of land for adventurers and soldiers, but in the more efficient mapping and surveillance of that land (in the cartographic work of William Petty and the censuses respectively). ${ }^{25}$ Over 10,000 landowners were forced to renounce their estates in accordance with the Commonwealth legislation; ${ }^{26}$ perhaps 45,000 people travelled west, to the more barren regions of Connaught, though the vast majority stayed where they had lived, residing now as tenants and thereby subject to vast social upheavals that also carried implications in terms of their new relationship to the land. The overall depopulation of Ireland's landscape also carried implications for the perpetuation of collective memory, with a fortytwo per cent decline in population from 1641 to $165^{2}$-due, it should be said, to the 1641 uprising and confederate campaigns as well as Cromwell's actions. Meanwhile, these developments took place in a landscape laid waste by a scorched earth policy conducted in the years $165^{\circ}$ to 1653 , after Cromwell had left; this left 11 million acres, half of Ireland, requiring planting, which would be conducted by New English owners and settlers. Planning was thus set in motion, as Smyth puts it, for 'the phenomenal transformation of the economic, cultural, and political geography of Ireland', as the 'whole island now lay at the mercy of the Commonwealth'. ${ }^{27}$

In this new dispensation, maps became instruments of state power in the administration and control of territory, in order to regulate, allocate, and tax the newly confiscated lands. This was not new to the Cromwellian period; for Attorney General Sir John Davies, writing in the early seventeenth

From "collective memory" to the historical sociology of mnemonic practices', Annual Review of Sociology 24 (1998), 105-124.

24 See Kerwin Lee Klein From history to theory (Berkeley, CA: University of California Press, 2011), 116.

25 Bottigheimer, English money and Irish land.

${ }^{26}$ Jane Ohlmeyer, Making Ireland English. The Irish aristocracy in the seventeenth century (New Haven and London: Yale University Press, 2012), 28off.

27 Smyth, Map-making, 170. 
century, mapping was not only an instrument of state control, a means by which 'every plot of land' could be made 'amenable to state regulation, allocation, inspection and taxation', but it also represented a form of knowledge, a science that reflected English colonial identity. By contrast, the rejection of this cartographic science was made unfortunately manifest in the murder of the military cartographer Richard Bartlett by the inhospitable natives of Ulster, who-in John Davies' words, 'would not have their country discovered'. ${ }^{28}$ Despite this setback, the colonizing mapping of Ireland continued, resulting in William Petty's famous and unprecedented Down Survey of the 1650s; like Bartlett, Petty worked within a military context, which would continue into the nineteenth century as Ordnance Survey mappers worked alongside sappers to 'name, own, and reconfigure' the landscape. In all cases, the progression was the same, writes John Andrews, as colonial cartography moved seamlessly from 'regional sketches to fort plans, and thence to plantation surveys and estate plans'. 29

Maps for the English thus served as a form of printed and therefore fixed (though not necessarily public) knowledge that stood in contrast to a landscape memory that was primarily oral, mostly localised, inaccessible to outsiders, and passed down through generations-in other words, the landscape knowledge held by the Irish or Old English. Most scholars focus on the permanent record and representation of landscape conducted by the English on the Irish; it is important, however, to understand this counter-knowledge of the land that persisted in the midst of these new cartographic and surveying impositions, particularly as they existed as a response and even a form of resistance to the official record of a Down Survey. The oral record as it exists in the National Folklore Collection and earlier transcriptions, for example, repeatedly echoes not with memory of the massacres at Drogheda and Wexford but with the land and its transference away. 'The time that Cromwell came to Ireland [and] put the people out of their lands and gave it to his own soldiers' is a repeated statement, occurring in reminiscences from all counties, in originary tales of how one property was gained, lost, or subject to different machinations or trickery on both sides. Some tales simply recall the bare facts, as with

28 C.W. Russell and John P. Pendergast (eds.), Calendar of state papers, Ireland, James I, 1608-1610 (London: Longman, 1874), 280.

29 See John Andrews, Shapes of Ireland. Maps and their makers 1564-1839 (Dublin: Geography Publications, 1997), p. 118. See also John Andrews, A Paper landscape. The ordinance survey in nineteenth-century Ireland (Oxford: The Clarendon Press), 1975. 
one eighteenth-century description of a Wexford bishop, born in Kilkenny, whose grandfather had lost 'a very large [estate] by Cromwell's sanguinary proscriptions'. ${ }^{30}$ Or: 'There was a man and his name was [Carson]. He had [six?] miles of the best land and there was nothing living on it but horses, cattle and sheep and he even had the rabbits. No one could take one rabbit out of the [fields]'.31 The term 'sanguinary' reappears again, in the more heated early nineteenth-century memoir of Miles Byrne, who spreads the blame more widely, writing that the land belonging to his ancestors remained with 'the descendants of the sanguinary followers of Cromwell, who preserved their plunder and robberies after the restoration of that scoundrel Charles II' ${ }^{32}$

Yet numerous examples also exist that reveal agency on the part of Irish who outwit the colonialist presence through cleverness or opportunity. ${ }^{33}$ Thus does a stonebreaker provide dinner for a half-starved Cromwellian soldier who is on his way to claim land (or 'ill-gotten gains'); as payment for dinner, the stonebreaker is given a grant of 2000 acres in return. Another tale recounts Cromwell expelling monks from an abbey and bequeathing the property to a tinker 'breaking stones on the side of the road'; afterwards he was given his demanded reward - the property - in return for directions to the place. ${ }^{34}$ The reality, of course, was different, with no rewards for tinkers and stone-breakers. As William Smyth has pointed out, the allocation of land during the Cromwellian settlement was not only relatively systematic but undertaken with military discipline; while exceptions did occur, fierce competition frequently existed between the claims of the army and those of the adventurers back home, who had been promised land in return for their financial support of the campaign ${ }^{35}$ _all very different from the claims of the alternative folkloric narrative.

Mapping and surveying also required the redesignation or anglicizing of place-names - a process most famously memorialised in Brian Friel's play

30 Finn's Leinster Journal, 1 November 1786 (Carrigan, Ossory, iii, 333). For other droll examples, see also The Parliamentary Gazeteer of Ireland (Glasgow, 1844), 744; National Folklore Collection, University College Dublin, Main Manuscript Collection (hereafter IFC), \#1417, I.4.

31 IFC \#1405, I.134.

32 Miles Byrne, Memoirs I (Dublin: Maunsel, 1907), 3.

33 See for example Thomas Crofton Croker (ed.), The tour of the French traveller M. de la Boullaye le Gouz in Ireland (London: T. and W. Boone, New Bond Street, 1837), 28 (n. 54), 98 .

34 National Folklore Collection, University College Dublin, Schools' Manuscript Collection (hereafter IFC S), \#862,I.313.

35 Smyth, Map-making, 190-191. 
Translations regarding the nineteenth century, even if the Englishing of the landscape began much earlier. ${ }^{36}$ In this regard, and as in a palimpsest, English names were superimposed onto the landscape, overlaying if not altogether erasing the traces of previous names and the memories behind them. But once again, the oral and literary culture perpetuated its own counter-naming processes that incorporated and subverted Cromwell's presence; the town of Dundrum, for example, was said to have earned its name when one of the drummers in Cromwell's army decided to quit his position and settle where he was, claiming, 'I'm done drumming'. In actuality, Dundrum - a suburb of Dublin — was not founded by a Cromwellian but was an ancient location centred on a church and dating to the sixth century and fortified by the Normans beginning in the twelfth century. In addition, many of the names did not simply mark destruction and loss but also memorialised the death of Cromwell's own men, and by the same token, the small victories of Ireland's defenders. Tales were woven of the Trooper's Mound in Westmeath, where many Cromwellian soldiers were said to have been killed and buried; or in Sligo, a sheer drop into a ravine known as the 'Protestant Fall', where Cromwellian soldiers plunged after being tricked to go there by locals. ${ }^{37}$ Such informal, unofficial names were significant for they helped to consolidate identity in the encoding of language and historical referents in a manner closed to outsiders, all of which was important as a means to grasp agency in a world of otherwise overwhelming impositions. ${ }^{38}$

Cromwell in the folklore was himself said to have joined in with the unofficial place-naming, as illustrated by one folk story, which also captures the yoking of Cromwell to a range of motifs and therefore deserves some analysis in its own right. 'Cromwell was a big English general and a bad man', begins the tale from the West; 'He'd stick the bayonet in the child and hold it up in the air until one of his officers would fire a shot through it. When he came to County Clare, he never halted until he came as far as Spancil Hill and 'twas Cromwell that started the first horse fair in Spancil Hill on June twenty-third'. ${ }^{39}$ Keeping in mind that folk tales truly come alive only in the telling and that they are characterised by

36 Smyth, Map-making; Ted McCormick, William Petty and the ambitions of political arithmetic (Oxford: Oxford University Press, 2009), 117.

37 IFC S. \#156, I.150-52.

38 Gerry Smyth, Space and the Irish cultural imagination (New York and Basingstoke: Palgrave Macmillan, 2001), 48-51.

39 See Henry Glassie, Irish folk tales (New York: Pantheon Books, 1985). 
ever-changing fluidity in narrative, the odd juxtapositions within this story are nevertheless revealing. On the one hand, the recounting of the murdered child reflects a time-worn trope of atrocity literature extending back through ancient times and most recently appearing in English pamphlets as well as John Temple's martyrological account written in the wake of the 1641 uprising - an account that told dozens of lurid tales relating to babies being piked, hanged on clothes lines, or of course taken from their mothers' wombs. But to follow the image of the baby with a straightforward account of the first horse fair in Clare brings a banality to the story, resulting in the fusion of fiction with fact, the nowhere of place (it is not clear where Cromwell 'ordered the execution' of the child) with the topographically specific (Spancil Hill, Clare). The tale thus captures both dimensions of the colonial experience - the malignant and the ordinary, the moral and the utilitarian, the bad and, with the horse fair, the arguably good; it reflects the capaciousness of memories to hold contradictions within themselves, while also expressing ambiguity of experience.

Much of the folklore derived from the territories around the Pale, which may account for the transmission of a vibrant Cromwellian-related oral culture to and from England, based on common motifs. ${ }^{40}$ Cromwell's copper nose has already been mentioned, as it circulated in England and then migrated over, as a kind of floating legend, to Ireland. The persistent theme of Cromwell's ubiquity was also evident in English popular culture, where he appeared in bodily form in places he had never visited or as a spectre drifting across the land; as in Ireland, English folklore also abounded with stories of Cromwell stabling his horses in churches, leaving behind the impression of hoofprints on the floor. But differences in the folklore are also revealing. Protestant England did not have additional tales of monks being thrown into rivers, priests being hanged from trees, crosses being smashed, holy water fonts miraculously surviving destruction, chalices and the gold of monasteries and churches being

40 Alan Smith, 'The image of Cromwell in folklore and tradition', Folklore 79 (1968), 17-39; Seán Ó Súilleabháin, 'Oliver Cromwell in Irish oral tradition', Folklore Today (1976), 73-483; Adam Fox, 'Remembering the past in early modern England. Oral and written tradition', Transactions of the Royal Historical Society 9 (1999), 233-256, there 241. For oral culture in England in general, see for example Daniel R. Woolf, "The "common voice". History, folklore and oral tradition in early modern England', Past and Present 120 (1988), 26-52; Walter Johnson, Folk memory, or the continuity of British archaeology (Oxford: Clarendon Press, 1908), 13; Michael T. Clanchy, 'Remembering the Past and the Good Old Law', History 55 (1970), 165-176, there 167 ; Keith Thomas, The perception of the past in early modern England. The Creighton Trust Lecture 1983 (London: University of London, 1984), 8-9. 
buried or preserved as relics, and appearances arising of the Blessed Virgin. In Ireland, landscape thus became more connected than ever before to Catholic imagery and iconography - a connection which of course had existed for centuries, though not to the extent that the land was called upon to resist an unprecedented invader, and one who framed his own conquest in godly terms.

In martyrological and popular literature as well as folklore, fugitive priests on the run from Cromwell and his men also constituted a frequent motif as they assumed a kind of itinerancy that mirrored Cromwell and his soldiers' own roaming omnipresence. ${ }^{41}$ More noteworthy than tales speaking of sympathisers coming to the aid of such men are stories of the land itself, alive with faith, and rising up in resistance. Rocks especially served as active protectors of the besieged innocent; in one story, a hunted priest is chased on the Mullet peninsula by Cromwell's men until he finds refuge on the beach, under rocks which miraculously appear and hide him successfully until his own people arrive. ${ }^{42}$ The priest is significant not only in asserting a Catholic dimension to a man-and by extension, a country - under siege, but it also once again reinforces Catholicism as an essential component in an oppositionally defined identity and presents the landscape itself as a divine intercessor in the resistance against evil.

Ruins also became part of the memory landscape, with Cromwell's targeting of monasteries and churches a constant reminder of defeat (even if many of those monasteries first entered their decline if not destruction under Henry VIII). In his travels with Mountjoy, the aforementioned cartographer Richard Bartlett, for example, sketched a number of 'new' ruins, most notably O'Neill's burned and destroyed castle at Dungannon, now with the flag of St George flying over it. ${ }^{43}$ In the eighteenth century, the sketches of English or Anglo-Irish antiquarians such as James Boyle tended to collapse Cromwellian ruins with megalithic monuments, castles, and churches, thus projecting Cromwell's legacy into a misty past. Others were

41 See Nicholas French's seventeenth-century Apologia, written upon his departure from Ireland, quoted in Denis Murphy, Cromwell in Ireland. A history of Cromwell's Irish campaign (London: M. H. Gill \& Son, 1885), 163-164.

42 See for example John Lynch, Cambrensis Eversus, seu potius Historica fides in rebus Hibernicis Giraldo Cambrensi abrogata; in quo plerasque justi historici dotes desiderari, plerosque nævos inesse, ostendit Gratianus Lucius, Hibernus [pseud.], qui etiam aliquot res memorabiles Hibernicas veteris et novæe memorice passim e re nata huic operis inseruit: impress. an. MDCLXII (Dublin: Celtic Society, 1848), vol. 1, 82, 166 (n. 42.)

43 Glenn Hooper, 'Planning control. Cartouches, maps and the Irish landscape', in Glenn Hooper (ed.), Landscape and empire, 1770-200o (Aldershot and Burlington, VT: Ashgate, 2005), 40. 
not so romantic about the legacy, however. In the early eighteenth century, Jonathan Swift, for example, would refer to Cromwell's ruins in the following words, 'Examine all the eastern towns of Ireland, and you will trace this horrid instrument of destruction, in [defaced] churches...nine in ten of them lying among their graves and God only knows when they are to have a resurrection'. Like Cicero on his return from Asia, Swift surveyed all before him, as it lay 'prostrate and in ruin' - due, he wrote, to Cromwell. ${ }^{44}$

The ruins of a landscape could also bear the folkloric mark of Cromwell, as in the Round Tower on Aran (which actually was felled in a gale), numerous stone crosses (evidence of Romanism), or various castles ('If any great man stood against him, he would pull down his castle'). ${ }^{45}$ As one Ordnance Survey administrator was to write in the early nineteenth century, 'almost every devastation of the kind is attributed to [Cromwell], perhaps with some justice, as he certainly could not be charged with any great love of popery or its emblems' ${ }^{46}$ English ruins thus represented the distressing aftermath of Cromwell's regime, but they also embodied another meaning distinctive to the land. In Kevin Whelan's words, if the Enlightenment and Romantic English ideal held that ruins were a nostalgic reminder of a vanquished past, yet one that held continuity to the present, as a mature living state 'recalled' its childhood, the ruins of Ireland, 'from an anti-colonial Irish perspective', were seen as a 'traumatic tear in the fabric of time', with tradition and custom 'not based on continuity but on violence, instability, and discontinuity'. In this sense, ruins were 'materialisations of the colonised's defeat, the presence of absence, in which the long-term effects of historical trauma [became] fixed in place' ${ }^{47}$

44 Jonathan Swift, Works (London, 1900), vol. 13, 29.

45 See, however, Smyth, Map-making, 164 for the number of ruined castles in Co, Tipperary in 1654 .

46 Ordnance Survey Letters (hereafter OS), MS 389 (bk 118, 1839); Parish Church of Clonmore [Carlow].

47 Kevin Whelan, 'Reading the ruins. The presence of absence in the Irish landscape', in Howard B. Clarke et al. (eds.), Surveying Ireland's past. Multidisciplinary essays in honour of Anngret Simms (Dublin: Geography Publications, 2004). See also Luke Gibbons, 'Romanticism in ruins. Developments in recent Irish cinema', The Irish Review 2 (1987) 59-63; Luke Gibbons, 'Between Captain Rock and a hard place. Art and agrarian insurgence', in Tadhg Foley and Seán Ryder (eds.) Ideology and Ireland in the nineteenth century (Dublin: Four Courts Press, 1998); and Georg Simmel, 'The ruin', in Kurt H. Wolff (ed.) Georg Simmel, 1858-1918. A collection of essays with translations and a bibliography (Columbus, OH: Ohio State Univ Press, 1959), 266. Georg Simmel wrote of ruins that the past with its destinies and transformations has been gathered into this instant of an aesthetically perceptible present'. 
It was perhaps inevitable that the great issues of the nineteenth century - namely, land tenure and reform, Catholic emancipation, and rising nationalism - would also lead to the invocation of Cromwell's name, which by then had assumed the form of a kind of imaginative and all-purpose signifier, a symbol of what one nineteenth-century newspaper called the 'land hunger of the Anglo-Saxon race'. ${ }^{48}$ And Cromwell was certainly a fitting name to recall, since the various Land Acts of the later nineteenth and early twentieth centuries were attempts to address discriminatory ownership laws that derived from Cromwellian policy and reached their peak in the eighteenth century. Accompanying these attempts to reform property ownership and land tenure by also looking again to where it all originated were parallel developments in historiography and poetry that placed a new kind of emphasis on the violence of the Protector, and his role as the 'butcher of Drogheda and Wexford'. Celtic revivalists such as Yeats, however, would not cast hatred onto Cromwell as much as they would attempt to scratch him from the record or limit his presence severely in their own folklore anthologies; for them, Cromwell represented an interlude best left forgotten in the quest to retrieve a more authentic and mythical-indeed, a yet earlier pre-modern and archaicIrish past. As Declan Kiberd has written, for Yeats the 'Cromwellian' encompassed not only imperialism but dreary, dream-barren middle class consciousness as well as the leveling vulgarity of the Cromwellian planters'. ${ }^{49}$ Yet for all the ruins he left behind, and despite the effacements of Yeats, Cromwell also stood at a positive place in the formation of an emerging Irish identity, beginning not in the nineteenth century but in the early modern period; the fact that he 'lived on' in different guises as well as regions and counties - most of which, again, never bore his actual presence-served to unite the country through a common if regionally varied constructed 'memory' that conveyed agency and resistance in the period of the Protestant ascendancy.

Whether sinister or comic, physically embedded in the land or traveling from county to county, the Cromwell of early modern memory thus represented the source of different living fictions that rebounded through the diverse and regional popular cultures. ${ }^{50}$ Landscape lore particularly

\footnotetext{
48 Quoted in John P. Pendergast, The Cromwellian settlement of Ireland (London: Longmans, Green, Reader and Dyer 1870), 135 (n. 2).

49 Declan Kiberd, Inventing Ireland. The literature of a modern nation (New York: Random House, 2009), 483 .

50 Trouillot, Silencing the past, xix.
} 
grounded Cromwell spatially and temporally in a place, as a 'thing that happened here', or as a force which was both 'factual and mythic', claiming the rocks or the sea at the same time that those topographical features could rise up against him. Yet to incorporate Cromwell into popular memory was also, in a sense, to bring him into the national story, and landscape, of Ireland and to perhaps even make a claim on him as well. He was alien because the soil rejected him or brought magpies which darkened the skies, strange birds bearing ill-fortune; but the Cromwell of popular memory was also fused onto existing folkloric tropes, or incorporated into a long-held Irish pantheon of myth. He was a devil, a usurper, a conqueror, yet his engagements with the land and its people - and on a larger level its myths and folklore-transformed him into something distinctly 'Irish' as well. Perhaps this is one reason for the bizarre tales that speak of Cromwell being born and raised in Ireland, or even ascending to the Irish kingship, before leaving for England and returning as a conqueror, to betray his own people. Such was the distinctly 'pre-modern' memory that persisted alongside later narratives: a more dynamic, diverse, and contested set of memorialisations than the linear and historical accounts of modernity but no less important for the way they affected a changing national identity, and one based, then as before, in the land and the stories it told. 


\title{
MATERIAL MEMORIES OF THE GUILDSMEN. CRAFTING IDENTITIES IN EARLY MODERN LONDON
}

\author{
Jasmine Kilburn-Toppin
}

In July 1528, William Vynyard, former master and major benefactor of the Armourers' guild of London donated to his fellow guildsmen a polychromed oak sculpture of St George, patron saint of the company (figure 9). Standing at just under a metre high and clad in miniature iron armour which had been crafted in the workshop of Vynyard himself, the sculpture was set before the high table in the Armourers' communal Hall, the highlight of a broader visual and material culture of devotion and memorialisation. ${ }^{1}$ The Armourers' model of St George, a virtuoso piece of craftsmanship, was retained by the guild throughout the early modern era. A rare pre-Reformation survival, this sculpture is still in situ within the institutional home of its maker. ${ }^{2}$ As one of the Armourers' most prized corporate possessions in the sixteenth and seventeenth centuries, the sculpture played an active role in the rich ceremonial life of the guildsmen - within and outside the Armourers' Hall-and became the founding piece in a large collection of miniaturised and full-sized suits, all of which were connected to the workshops and memory of significant makers and guildsmen.

Within the late-medieval craft fraternities and early modern guilds of London, the gifting of material culture for display in livery halls, and use in company rituals, was a significant means for guildsmen to establish reputations in life and uphold memory within the craft community after death. Though the Reformation swept away the intercessory value of material objects, physical things continued to act as significant prompts for the memorialisation of a guildsman's achievements, skills and qualities in life. In the following chapter, material gifts and bequests by craftsmen

\footnotetext{
1 William Vynyard was master of the Armourers' Company on three separate occasions: 1503-04, 1513-14 and 1531-32.

2 For the devastating consequences of iconoclasm upon English sculpture survival, see: Richard Deacon and Phillip Lindley, Image and idol. Medieval sculpture (London: Tate, 2001).
} 


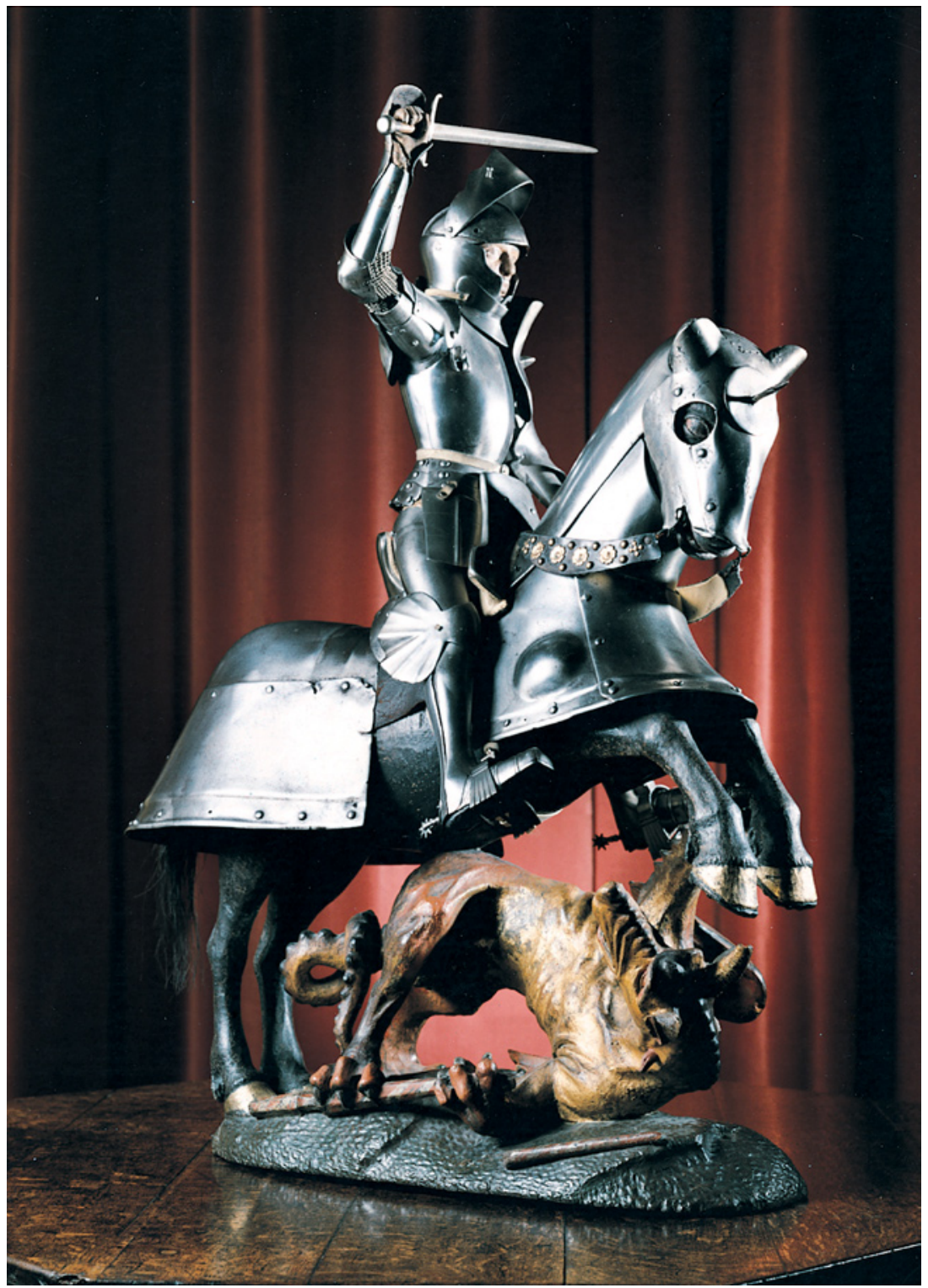

Fig. 9. St George and the Dragon, c. 1528, polychromed oak, iron, leather and horse hair, Armourers' Company, London. 
to their guilds are considered as dynamic bearers of personal and communal memory and cultural identity across the early modern period. Though objects had particular meanings or resonances at the point of donation, these material 'things' also continued to have active social and ritual lives for many decades beyond, thus perpetuating the memory of the dead within the community of living guildsmen. ${ }^{3}$ Therefore in contrast to the existing historiography of English civic institutions, which has proposed a decisive shattering of time-honoured cultures of collective memory in the wake of the Reformation, this chapter will suggest that within the early modern artisanal guild, memory cultures displayed aspects of continuity, as well as change. ${ }^{4}$ Fundamentally, the communal identity of a craft guild as an association of skilled makers of physical things had a bearing on how individuals shaped their post-mortem reputations. Particular materials, tools and visual representations of accomplished artisanal labour were significant foundations in the construction of personal and collective memories within the political and social body which constituted a London livery company.

The guilds of early modern London originated from late-medieval craft fraternities. These associations of craftsmen were bound together through mutual economic regulation and support, shared standards of respectability and dedication to a patron saint; usually a figure specifically associated with their particular workshop practice. ${ }^{5}$ As one of the most revered warrior saints throughout Christendom-allegedly an army officer who was martyred in the late third or early fourth centuries - the chivalric, crusading St George was naturally a favourite among armourers' guilds across Europe, and the London Armourers were no exception. ${ }^{6}$ The

3 Arjun Appadurai, 'Introduction. Commodities and the politics of value', in his The social life of things. Commodities in cultural perspective (Cambridge: Cambridge University Press, 1986), 3-63.

4 Robert Tittler, 'Reformation, civic culture and collective memory in English provincial towns', Urban History 24 (1997), 283-300; Robert Tittler, The reformation and the towns in England: politics and political culture, c. 1540-1640 (Oxford: Clarendon Press, 1998); Victor Morgan, 'The construction of civic memory in early modern Norwich', in Marius Kwint, Christopher Breward and Jeremy Ansley (eds.), Material memories (Oxford: Berg, 1999), $183-197$.

5 George Unwin, The gilds and companies of London (4th ed., London: Frank Cass, 1966), 93-126; Gervase Rosser, 'Crafts, guilds and the negotiation of work in the medieval town', Past and Present 154 (1997), 3-31.

6 Jonathan Bengtson, 'Saint George and the formation of English nationalism', Journal of Medieval and Early Modern Studies 27 (1997), 317-340; Muriel C. McClendon, 'A moveable feast. Saint George's Day celebrations and religious change in early modern England', Journal of British Studies 38 (1999), 1-27. 
Goldsmiths' guild revered the figure of St Dunstan, said to be a skilled tenth-century Glastonbury metalworker. ${ }^{7}$ As bodies which nourished the spiritual, as well as social and economic needs of their members, these craft fraternities were deeply involved in the 'cult' of the dead: the rich culture of memorialisation, centred on a belief in Purgatory, which bound living and dead communities together through perpetual cycles of masses, indulgences and fasts. ${ }^{8}$ A collective memory culture in which visual and material representations, signs or embodiments of the Holy Family and 'heavenly society' of saints acted as essential-if not entirely uncontroversial-intercessory tools. ${ }^{9}$ Crucially, the late-medieval craft fraternities provided lights in honour of their patron saints, and the memory of departed brothers; they organised alms, prayers and funerals for their members and on significant days in the ritual calendar, hosted feasts for the advancement of commensality and charity amongst the living brethren. ${ }^{10}$ The London Armourers' guild acquired the advowson of a chantry dedicated to St George in the Chapel of St Thomas in St Paul's Cathedral in the first half of the fifteenth century and were not unusual-among craft institutions in the city-in maintaining such perpetual supplications to their patron saint." ${ }^{11}$ The mercantile guilds with the wealthiest members and largest endowments supported multiple intercessory services at any one time; the Guild of the Merchant Taylors of the Fraternity of St John the Baptist funded nine chantry priests and an additional fourteen obits. ${ }^{12}$

Craft fraternities usually had close associations with city churches in the same streets and parishes as their guild halls, and it was in these spaces

7 Douglas Dales, 'Saint Dunstan, patron saint of goldsmiths', in Timothy Schroder (ed.), Treasures of the English church. A thousand years of sacred gold and silver (London: Goldsmiths' Company in association with Paul Holberton Pub., 2008), 11-15.

8 Eamon Duffy, The stripping of the altars. Traditional religion in England, c. 1400-c. 1580 (2nd ed., New Haven and London: Yale University Press, 2005), 301-302.

9 For a recent analysis of the ambivalent [or 'paradoxical'] relationship between materiality and devotional objects in a pre-Reformation context, see: Caroline Walker Bynum, Christian materiality. An essay on religion in late medieval Europe (New York: Zone Books, 2011).

10 Duffy, The stripping of the altars, 142-144; Barbara Hanawalt, " Keepers of the light". Late medieval English parish gilds', Journal of Medieval and Renaissance Studies, 14 (1984), 26-37; Gervase Rosser, 'Going to the fraternity feast. Commensality and social relations in late medieval England', Journal of British Studies 33 (1994), 430-446.

11 Elizabeth Glover, Men of metal. History of the Armourers and Brasiers of the City of London (Huddersfield: Jeremy Mills for The Worshipful Company of Armourers and Brasiers, 2008), 24.

12 Charles M. Clode, Memorials of the Guild of Merchant Taylors of the Fraternity of St. John the Baptist, in the City of London (London: Harrison \& Sons, 1875), 84-92. 
that members' funerals were held, and prominent brothers buried and memorialised. In the late sixteenth-century Survey of London, the historian John Stow revealed some of the significant connections between medieval craft fraternities, places of workshop and memorialisation of members. In the ward of Aldersgate, the site of the Goldsmiths' Company Hall, lay the church of St John Zachary, which many brothers of the fraternity had sponsored and were subsequently remembered within: 'A fayre church, with the monuments wel[l] preserved, of Thomas Lichfield who founded a chauntrie there ... Nicholas Twiford, Goldsmith, mayor 1388 . . of whose goods the church was made and new builded, with a tomb for them and others of their race...' (and so the list continues, naming nearly a dozen significant goldsmiths).$^{13}$ In the parish church of St Leonard, located on the same lane as the Goldsmiths' Hall, there was a monument to Robert Trappis, a goldsmith, who died in $15^{26}$, with an epitaph which deliberately played with notions of memorialisation or remembrance: 'When the bel[l]s be merily roong, And the masse devoutly sung, And the meat merily eaten, Then shall Robert Traps his wives And children be forgotten'. ${ }^{14}$ The goldsmith Henry Coote, who passed away in 1513, left seventy pounds to St Dunstan's chapel in the church of St Vedast, for the rebuilding of the chapel and a glass window 'to be made according to a pattern I have caused to be made containing the life of St Dunstan and the figures of me and my two wives'. ${ }^{15}$

Inventories compiled by late-medieval craft guilds show that members established their identities or reputations in life and memory after death, through the donation of material goods and furnishings for neighbouring churches and their institutional homes, the livery halls. An inventory taken in 1490 by the 'bretherhode of the assumpcion of our Blessid Lady of the crafte of pewter of London', a list of gifts donated and bequeathed to the guild by its members, records textiles, silver plate and torches or lights, items which were linked specifically to the performance of Eucharistic worship, 'a much favoured way of securing remembrance'. ${ }^{16}$ Guildsmen also gave the essential material apparatus for carrying out the funerals of brothers of the fraternity, such as 'a bla[c]k cofyn with iii chapelet[s] of

13 John Stow, A survey of London, ed. Charles Lethbridge Kingsford, 2 vols. (Oxford: Oxford University Press, 1908), vol. 1, 305.

14 Ibid.

15 Thomas F. Reddaway and Lorna E. Walker, The early history of the Goldsmiths' Company, 1327-1509 (London: Edward Arnold, 1975), 293.

16 Pewterers' Company, 'Inventories 1490-1838', MS 7110, Guildhall Library, London; Duffy, The stripping of the altars, 331 . 
red saten with the ymage of our lady assumpcion of sylver'. ${ }^{17}$ Silver and pewter plate such as apostle spoons, cups and bowls, and textiles such as table and banner cloths, were also given to the craft for the performance of commemorative funeral feasts, dinners and civic processions which punctuated the ritual calendar of the guild; most significant was the election of the new master and wardens (which was usually held on the patronal feast day). This was an event to which members of the civic elite (from outside the specific guild) might be invited, and thus a valuable opportunity for observing ritual practices and interior furnishings of rival companies. The end of the annual election process was marked by a church service on the Sunday following the election feast, during which a mass requiem for the dead members was heard, prayers were made for the departed and the priest said a prayer for the entire surviving brotherhood 'naming each individual separately by name'. ${ }^{18}$ The Pewterers' inventory also shows that guildsmen materialised their memory within the company Hall through the sponsorship of windows; in 1494, seventeen individual guildsmen paid for the glazing of window panels in the hall, including a bay window and 'the high window over the high dais', using 'flemysshe' and 'normandy' glass. ${ }^{19}$ Coloured glass panes bearing benefactors' arms were also installed in the fifteenth-century halls of the Carpenters' and Merchant Taylors' Companies. ${ }^{20}$ Guildsmen took care to ensure that their heraldry was displayed in the most prominent spaces, and thus after death, their memory (and that of their ancestors), would be associated with political prestige within the guild. ${ }^{21}$

This culture of collective memorialisation within the London guilds was undoubtedly disrupted by the Reformation, specifically by the injunctions of the 1540 , which outlawed fraternities, chantries, the provision and performance of obits and the burning of lights. ${ }^{22}$ Fundamentally, craft guilds were no longer permitted to perform intercessory acts on behalf of dead members of the brotherhood. But though the traditional 'cult of the dead' had been undermined, the guild institutions themselves, as economic,

17 MS 7110, f. 2v.

18 William Herbert, The history of the twelve great livery companies of London, 2 vols. (London: William Herbert, 1837), vol. 1, 68-69.

19 MS 7110, f. 4v.

20 John Schofield, Medieval London houses (New Haven and London: Yale University Press, 1995), 106.

21 MS 7110, f. 4v.

22 Duffy, The stripping of the altars, 451-455; Herbert, The history of the twelve great livery companies, vol. 1, 113-115. 
political and social bodies, and their built environments, thrived. The craft guilds and their company halls continued to be important arenas for establishing and upholding post-mortem reputations and social memory, and guildsmen continued to give material gifts (including plate, textiles and furniture), as a focus or prompt for remembrance. As in the pre-Reformation era, objects were given for the performance of specific rituals; masses had been abolished, but guildsmen still donated objects for use at funerals, feasts and civic processions. ${ }^{23} \mathrm{In} 1605$ for instance, ' $\mathrm{Mr}$ Richard Lockson [an armourer] and Isabell his wife gave a velvett cloth imbroidered to bee used att ye buriall of any of ye assistants or livery of ye [Armourers'] Company'. ${ }^{24}$ Court minutes and accounts from across the London companies show that the funeral and burial of a guildsman continued to be a communal responsibility. A guildsman's coffin would be draped with the company hearse cloth, some of which were adapted late-medieval survivals, and members were urged to witness the burial, attend the sermon or hear the preacher, and subsequently participate in the memorial drinks or dinner in the livery hall, in his honour. ${ }^{25}$ In their last wills and testaments, prominent guildsmen provided funds for such occasions of remembrance (and no doubt sociability), and some bequeathed plate specifically for use at the table; at their memorial dinner and during subsequent rites of commensality. At his death, David Gitting, a member of the Vintners' Company, left a relatively humble ceramic pot with silver mounts to his guild, with the following inscription: 'Thank David Gittings for yis [this]. Think and thank. 1563'. A senior member of the Skinners' Company, William Cockayne, bequeathed one hundred and twenty pounds for the making of five silver cups in the shape of cockerels, for use at guild election dinners at the feast of Corpus Christi. The novel

23 Vanessa Harding, 'Choices and changes. Death, burial and the English Reformation', in David Gaimster and Roberta Gilchrist (eds.), The archaeology of Reformation 1480-1580 (Leeds: Maney, 2003), 386-98, there 387 , 'many of the characteristics and accompaniments of the pre-Reformation rite continued to hold their (social) value both for the dying and for their survivors'.

24 Armourers' and Brasiers' Company, 'Will and gift Books', MS 12105, f. 17, Guildhall Library, London.

25 Guildsmen were also required to attend these commemorative events in the appropriate apparel. In 1567 for example, the carpenter Thomas Harper was fined $12 \mathrm{~d}$ for 'comyng in a wronge lyverie gowne at the buryall of Mr Trull' (Edward B. Jupp, An historical account of the worshipful company of carpenters of the city of London (London: W. Pickering, 1848), 141). 
design, playfully based upon his family name, created an unforgettable connection between the guildsman and his gifts. ${ }^{26}$

Guildsmen also frequently made bequests of silver, engraved with their familial arms and inscriptions that spoke of fraternal love and memorialisation. In $1630 \mathrm{Mr}$ Warden Leadam presented to the Goldsmiths' court a great standing cup and cover, with his own arms and that of the company engraven upon it and the inscription that: "This guifte I leave amongst my friends, Of that which God did give, That when I dye this guifte of myne Amongst my friends may live'. ${ }^{27}$ Two years later Mr Avenon, another goldsmith, also donated a silver cup and cover, with an inscription that clearly anticipated the convivial context in which the gift would operate: 'When at your Hall doth shine with plate, And all your dishes served in state, When mirth abound, and wine is free, then (freely drinking) think on me'. ${ }^{28}$ Through the use and display of such objects at guild feasts and dinners, 'amongst my friends', there must have been a very real sense that the memory of the deceased was revived, and that the community of guildsmen thus extended beyond the living, present company. ${ }^{29}$ Though plate collections were on occasion melted down or sold for the inherent value of the material during particularly acute financial crises, guilds might record crucial details before sale or destruction, which would subsequently be re-inscribed on new pieces of silver when the economic climate improved, thus preserving the memory of donors. ${ }^{30}$

If the Reformation had swept away the significance of memorialisation as a social process, which ensured intercessory activities of the living fraternity on behalf of the souls of the deceased, then how might we interpret the guildsman's continued desire to be remembered within mercantile and artisanal communities? It has been proposed that within reformed society at large, the memorialisation of individuals became focused upon Christian virtues, particularly charitable endeavours; thus we see a cultural shift 'from the active memory of the dead toward charity for

26 Philippa Glanville, Silver in Tudor and early Stuart England. A social history and catalogue of the national collection, 1480-1660 (London: Victoria and Albert Museum, 1990), 335. Unusually, these cups were permanently retained by the guild.

27 Walter Sherburne Prideaux, Memorials of the Goldsmiths' Company, 2 vols. (London: Eyre \& Spottiswoode, 1986-87), vol. 1, 150.

28 Ibid., $156-157$.

29 Sheila Sweetinburgh, 'Remembering the dead at dinner-time', in Tara Hamling and Catherine Richardson (eds.), Everyday objects. Medieval and early modern material culture and its meanings (Farnham: Ashgate, 2010), 257-266.

30 The Drapers' Company recorded benefactors' details and inscriptions on silver before disposal of plate in the 1640s; the Goldsmiths' Company in the 1630 s and 1660 s. 
the living'. ${ }^{31}$ Nigel Llewellyn has demonstrated that funeral monuments in post-Reformation England-objects which perpetuated the presence of the dead in the social and political communities of their descendantsno longer sought supplication, but rather demonstrated the deceased's achievements and exhorted observers to follow his godly example. ${ }^{32}$ In relation to the London guilds in particular, Ian Archer has convincingly suggested that the 'arts and acts of memorialisation' in the later sixteenth and seventeen centuries were focussed upon the recollection of charitable activities and accomplishments of the company elite: 'a spur to further charitable endeavour' and an affirmation or legitimation of 'a set of unequal power relations'. ${ }^{33}$ Within their company halls, guildsmen were repeatedly reminded of the benevolence and generosity of politically prestigious, dead brothers: their wills were recited on quarter days; their gifts were inscribed upon wooden tables, mounted upon company walls; their donations recollected at feasts and at sermons. ${ }^{34}$ At his death in 1566, Sir Martin Bowes-a hugely significant figure in life, who had repeatedly served as Master of the Goldsmiths' Company and once as Lord Mayor of London-left funds to his guild for an annual sermon and distribution of alms to the poor at St Mary Woolnoth, to be followed by a memorial feast in the Goldsmiths' Hall. ${ }^{35}$ In his last will and testament, drawn up in 1565 , Bowes also decreed that over thirty close family members and guild associates were to each be given a gold mortality ring of his own design, 'with two bowes bent and a deaths hedd graven between them ... with the inscripture about it "Remember the end"'. ${ }^{36}$ Guildsmen clearly wished to be remembered as benevolent, civic philanthropists; but within organisations whose primary purpose was the regulation of the craft or trade, and whose memberships were largely composed of working artisans, identity

31 Peter Sherlock, 'The reformation of memory in early modern Europe', in Susannah Radstone and Bill Schwarz (eds.), Memory. Histories, theories, debates (New York: Fordham University Press, 2010), 30-40, there 33.

${ }^{32}$ Nigel Llewellyn, Funeral monuments in post-Reformation England (Cambridge: Cambridge University Press, 2000), 255-256; Peter Sherlock, Monuments and memory in early modern England (Aldershot: Ashgate, 2008), 97-127.

33 Ian Archer, 'The arts and acts of memorialization in early modern London', in Julia F. Merritt (ed.), Imagining early modern London. Perceptions and portrayals of the city from Stow to Strype, 1598-1720 (Cambridge: Cambridge University Press, 2001), 89-113, there 9o; Robert Tittler, 'Portrait, precedence and politics amongst the London liveries c. 1540-1640', Urban History 35 (2008), 349-362, there 356 .

34 Archer, 'The arts and acts of memorialisation', 95-102.

35 Ibid., 101-102.

36 PROB 11/49, The National Archives, Kew. 
and memorialisation were also associated with one's virtuosity (in life) as a master craftsman. Further, this feature of commemoration-embodied in material things, and displayed in guild halls_-remained constant across the Reformation divide.

In 1567 , the armourer John Kelte was at the peak of his professional career: he had been selected to become a liveryman of his guild and he had achieved the honour of being appointed Master Workman at the royal armour workshops at Greenwich, the first English armourer to have been selected for this role since the royal workshops had been established by Henry VIII over fifty years before. ${ }^{37}$ At the election feast in that same year, Kelte presented his fellow guildsmen with a gift, carried on a platter to the high table before the multiple dishes of food: a miniature harness in the latest Greenwich armoury style, upon a wooden sculpture of St George, referred to as the 'George of compleat armo[u]r on foote' in the court minutes. ${ }^{38}$ Unfortunately this object is no longer extant; there are few material survivals from London guilds as a result of repeated fire and flood damage to company buildings. However another such model does survive from earlier in the century, for when Kelte presented his material gift to the Armourers' guild, another miniature sculpture of St George, fitted with steel armour, was displayed in the company Hall 'over the [hall] skrein [screen]' ${ }^{39}$

Forty years before Kelte gave his gift, the armourer William Vynyard had presented his guild with a polychromed oak sculpture of their patronal figure St George, clothed in a miniature suit of armour which had been crafted in the donor's own workshop. ${ }^{40}$ The Armourers' 'Benefactor's book', compiled in the 1660 s as a retrospective account of material gifts to the guild, demonstrates that the sculptural offering of William Vynyard, in 1528, was clearly intended to be part of the company's larger visual and material culture of religious devotion, civic honour and personal commemoration, housed within the Armourers' Hall on Coleman Street in the City of

\footnotetext{
37 Glover, Men of metal, 39.

38 Armourers' and Brasiers' Company, 'Inventories', MS 12107, f. 2r, Guildhall Library, London.

39 Armourers' and Brasiers' Company, 'Court minutes', MS 12071/2, f. 475v, Guildhall Library, London.

40 It is hard to ascertain why this sculpture of St George has survived to the present day; whereas almost all other pre-Reformation sculptures in England (including hundreds of this popular saint), were destroyed in waves of iconoclasm throughout the early modern era. It is possible that through its prominent role in the convivial recreations and civic representations of the guild, and its relocation to the Armourers' hall screen, its devotional associations were defused.
} 
London, a 'theatre' or 'site of memory' ${ }^{41}$ All the gifted items and furnishings for the Armourers' Hall, crafted by a range of artisans within the city, were no doubt expected to act as lasting embodiments of the donors' generosity, political influence and devotional piety; but the saintly sculpture given by Vynyard had a more nuanced symbolic value, for it represented the Armourers' patronal saint in the material and form in which the guildsmen themselves were familiar and skilled. ${ }^{42}$ In 1428, John Amflesh, who had been Master of the guild in the previous year, gifted to his guildsmen 'the hallyngs to the high deysse' [dais], an impressive set of 'steyned' or painted textiles, hung at the high end of the communal hall, which combined a visual representation of St George with celebratory textual verses by the poet John Lydgate. ${ }^{43}$ In the same year, two senior guildsmen 'gave the crest of the high deyesse with three angells', a wooden carving which framed the impressive textile, and the high table, below. ${ }^{44}$ Nearly a century later, in 1522 , with 'the hallyngs' still prominently displayed, Master of the Armourers' Company, John Alleyn, gave 'a table of joyners worke with the picture of St George upon it in vellom'. ${ }^{45}$ Significantly, when William Vynyard presented his St George sculpture to the Company, in that same decade, accompanied with 'a Lattin candlestick that is before it', he also fashioned the broader architectural and material context in which the figure might operate, including all 'the lattice [work] that be about the galleryes into the [hall] Chamber' ${ }^{46}$ The guild's annual commemoration of St George's Day, a great convivial event celebrated throughout the sixteenth and seventeenth centuries - which started with a mass, or a sermon from the 1570s-and whose highlight was the extravagant feast, hosted in the Armourers' Hall, would have been the moment when the sculpture and other material representations of their saintly patron performed to best effect. The figurative representation of St George also had a social or ritual life when the guildsmen presented their craft outside the Hall in a wider civic context, as for example when the company travelled

41 Pierre Nora, 'Between memory and history. Les lieux de memoire', Representations 26 (1989), 7-25; Archer, 'The arts and acts of memorialisation', 9o. The Armourers do not make it clear why this retrospective account was made at this date. It might have been related to the recent Restoration of the English monarchy (in May 1660).

42 The gifts are recorded from the later 1420s; from the acquisition of their communal hall at the northern end of Coleman Lane, in the City of London.

43 MS 12105, f. 2.

44 Ibid.

45 Ibid., f. 9 .

46 Ibid., f. 10. 
by boat to Greenwich in 1540, to celebrate the marriage of Henry VIII to Anne of Cleves, with 'banners, targets and our George standing over the rails' ${ }^{47}$ During the annual civic processions and theatrical performances of the Midsummer Watch and Lord Mayor's Show, the Armourers' sculpture of their patron saint might also have taken a prominent place in the company's pageant display. 48

Standing at just under a meter high, $(84.5 \mathrm{~cm})$, William Vynyard's figure of St George, his horse and their reptilian adversary were carved in the $15^{20}$ from a single piece of English oak. ${ }^{49}$ Dragon and visible elements of the Saint and his steed were polychromed, an entirely typical decorative feature of contemporary devotional sculpture. ${ }^{50} \mathrm{~A}$ sense of material veracity was achieved through the incorporation of genuine hair for the horse's tail, textiles for the saddle, studded leather for the reins and most strikingly of all, the perfectly proportioned full plate iron armour for man and horse. That the style of armour was intended to be that commissioned and worn for a joust or tournament is suggested by the broken lance on the base of the statue and gripped in the dragon's claws, as well as the reinforced left pauldron or shoulder-plate. Significantly, the suit was crafted by William Vynyard according to contemporary continental fashions for armour; the waistline is pinched (as stressed by a copper belt), there is an emphasis upon the commanding upper body (achieved through vertical ridges running down the breastplate), and the figure's sabatons or shoes are squared-toed, a clear contrast to the long tapering footwear which had been fashionable in the previous century. ${ }^{51}$ These traces of stylistic and technical engagement with Italian fashions, the centre of quality armour production in late-medieval Europe, would undoubtedly have been interpreted by an organisation of skilled metalworkers as an unambiguous statement of Vynyard's personal artisanal virtuosity. An impression which would have been heightened by the scale of the suit; differing from a full-sized armour simply in having its articulated parts made solid. ${ }^{52}$

47 Glover, Men of metal, 43-44.

48 Michael Berlin, 'Civic ceremony in early modern London', Urban History Yearbook 13 (1986), 15-27; Anne Lancashire, London civic theatre. City drama and pageantry from Roman times to 1558 (Cambridge: Cambridge University Press, 2002), 153-184.

49 Karen Watts, 'The arts of combat', in Richards Marks and Paul Williamson (eds.), Gothic art for England 1400-1547 (London: V\&A Publications, 2003), 192-208, there 199.

50 Michael Baxandall, The limewood sculptors of renaissance Germany (New Haven and London: Yale University Press, 1980), 48.

51 Angus Patterson, Fashion and armour in renaissance Europe. Proud lookes and brave attire (London: V\&A Publications, 2009), 33-35.

52 Watts, 'The arts of combat', 198. 
Miniaturised armour, as distinct from that made for young boys or adolescents, was a very rare spectacle in early modern Europe. The technical skills required for such an intricate assemblage of metalwork would have no doubt evoked curiosity or wonder. In this respect it is pertinent that Vynyard made such a material testimonial of his personal masterly skills in precisely the same era as the creation of the royal armour workshops at Greenwich, a centre established by Henry VIII for the production of impressive, bespoke tournament suits, by highly skilled Italian, Flemish and 'Almain' armourers. ${ }^{53}$ The presentation of miniature armour by the Master of the indigenous guild and subsequently the Master of the Greenwich workshops - by Vynyard in 1528 and Kelte in 1567 - must have thus been a substantial symbolic statement regarding the ability of English armourers to create customised suits themselves. The continued presence (and addition) of these armoured sculptures suggest that the association of their craft and personal memory with religious honour and antiquity was a valued cultural motif within the early modern guild.

Across late medieval and early modern Europe, armour, in general, was understood to be a hugely important statement of a man's taste, affluence and identity in life-as exemplified by the numerous portraits of kings and aristocrats posturing in their made to measure suits-as well as a particularly suitable artefact for ensuring that one endured as a figure of historic significance after death; a lasting shell which physically embodied personhood, perhaps even spirit. At the funeral of the Prince of Wales, heir to the English throne, in 1502, a knight clad in Arthur's own armour led the funeral procession; over a century later, Christian II, Elector of Saxony (1591-1611) had a loyal squire wear his bespoke armour at his own funeral, 'in effigie'. ${ }^{54}$ In both cases, the desired effect must have been for the customised armour-in motion-to suggest the continued presence of the 'political body' of the deceased. In his castle at Ambras, Ferdinand II, Holy Roman Emperor (1619-1637) had a specially constructed Rustkammer, a collection of arms and armour that had formerly been owned-and worn-by famous men. Decades after they had been crafted and donated (and their makers had passed into the illustrious community of deceased

53 Thom Richardson, 'The royal armour workshops at Greenwich', in Graeme Rimer, Thom Richardson and J.P.D. Cooper (eds.), Henry VIII. Arms and the man, 1509-2009 (Leeds: Royal Armouries, 2009), 148-154.

54 Llewellyn, Funeral monuments, 95; Heinz-Werner Lewerken, 'The Dresden armory in the new stable', in Dirk Syndram and Antje Scherner (eds.), Princely splendor. The Dresden court, 1580-1620 (Milan: Electa; Dresden: Staatliche Kunstsammlungen, 2004), $70-79$, there 79 . 
benefactors), Vynyard and Kelte's sculptures might have embodied both the presence of patron saint within the institutional home of his guildsmen and the skilled identity of the masterly armourers themselves. Inventories of communal possessions reveal that from the later decades of the sixteenth century, prominent men associated with the Armourers' Company had their (full-sized) suits displayed in the Armourers' Hall, along a specially constructed semi-public gallery. ${ }^{55}$ Within a space dedicated to the operation of the craft, this collection of suits represented the close connections between memorialisation of prominent members and the highly skilled practices of the associated artisanal practitioners.

In the early 1570 , several senior members of the Carpenters' Company of London commissioned a series of four wall paintings for the decoration of the dais end of their communal Hall, a building which was situated on London Wall, a short distance from the Armourers' institutional headquarters. ${ }^{56}$ The paintings — three of which are still extant - approximately three foot high and twenty-three foot in length, were applied directly onto plaster and were organised as a coloured narrative frieze, with each image framed and separated from the others by a classically-inspired architectonic border. The paintings depict the crucial role of carpentry throughout Old and New Testament biblical history: Noah receiving the command of God for the construction of the ark, and his three sons at work (Genesis 6:9-22); King Josiah ordering the rebuilding of the Temple at Jerusalem (2 Kings 22:1-7); Jesus (and Mary) loyally observing Joseph at work as a carpenter (Luke 2:41-52) and Jesus, 'the carpenter's son', teaching in the synagogue (Matthew 13:53-58). ${ }^{57}$ Each image is accompanied by the associated biblical verse in a black letter inscription; the clear emphasis on the 'process of a story', perhaps a self-conscious attempt to avoid allegations of idolatry. ${ }^{58}$ In three of the frames, full-bearded senior male figures are featured wearing contemporary livery dress of the $1560-70$ - - with distinctive blackcap and fur-trimmed gown-alongside those dressed in 'traditional' biblical costume. It is probable that these liverymen were likenesses of the commissioners of the paintings, and thus the guildsmen in question were immortalised in these historic narratives alongside senior

55 MS 12107, f. 6r.

56 Jupp, An historical account, 239.

57 All references from The Geneva Bible (1560).

58 Tessa Watt, Cheap print and popular piety, 1550-1640 (Cambridge: Cambridge University Press, 1991), 209. 
biblical figures. This personal inclusion within the mural was an enterprising means of establishing individual authority and memory within a broader visual statement about communal craft identity. Such a personal rendering within a wider pictorial narrative would also have alluded to the guild tradition, throughout late-medieval Europe, of patronal representation within ecclesiastical fixtures such as stained glass and altarpieces. ${ }^{59}$

Crucially, these wall paintings marked a significant event in the communal life of the guild, as they were commissioned by the liverymen at the beginning of a substantial rebuilding project: the paintings were undertaken at the same time as the dais end of the internal hall was wainscoted and a wood panelled gallery was also established. Within the next twenty years a new parlour had been built, a counting house was constructed and the internal hall was substantially enlarged 'at the east ende'. ${ }^{60}$ The paintings were thus not simply an isolated visual statement about the genealogy of the carpenters' craft but were themselves an integral element of the new built environment. The visual representations of reconstruction or rebuilding were highly apposite at a time of structural remodelling, and must have drawn attention to the surrounding materiality of the new Carpenters' Hall: the wood panelling in particular. In an age in which boundaries between 'wall' and 'painting' were yet to be precisely defined, a narrative history of the craft of carpentry had become literally embedded in the built fabric of the Carpenters' Hall, and memorialisation of eminent guildsmen inseparable from collective physical structures. ${ }^{61}$ Thus in the case of the Carpenters' Company, their newly modelled guild hall was itself the artisanal masterpiece, and interior decorative features drew attention to the senior craftsmen who had undertaken the rebuilding project and commissioned the wall paintings.

When the aforementioned armourer William Vynyard died in 1535, he bequeathed to his guild both his workshop tools-his anvil and plate shears-and enough money for the wardens and yeomanry to host a substantial 'drinking' in his honour; a memorial which would have taken place in their Hall, in the presence of Vynyard's figurative sculpture of

59 Duffy, The stripping of the altars, 163.

60 Carpenters' Company, 'Wardens' Accounts 1592-1622', MS 4326/6, f. 42r, Guildhall Library, London.

61 Juliet Fleming, Graffiti and the writing arts of early modern England (London: Reaktion, 2001), 32; Lucy Gent, 'The Rash Gazer': economies of vision in Britain, 1550-1660', in Lucy Gent (ed.), Albion's Classicism. The visual arts in Britain, 1550-1660 (New Haven and London: Yale University Press, 1995), 377-393, there 382. 
St George. ${ }^{62}$ Among prominent master craftsmen, Vynyard was not unusual in bestowing his personal artisanal tools to his guild, objects which embodied a lifetime of accumulated artisanal knowledge, experience and skill, and which appear to have been displayed within company buildings. At his death, in the mid sixteenth century, the armourer William Seger gave 'to the clothing [the liverymen] thirteen shillings fower pence to the yeomanry tenn shillings and to the hall a great biccorne [an anvil] and a paire of great sheires'. ${ }^{63}$ Members of the Pewterers' Company frequently donated workshop moulds to their guild, objects of considerable value, which were subsequently stored in the guild counting house or treasury alongside charters, wills and silver plate. ${ }^{64}$ Master masons routinely bequeathed workshop tools or instruments, building 'plots' or plans, designs and books: a 'cumulative resource' which represented erudition, craft knowledge and the sustained identity of the craft practitioner ${ }^{65}$ Significantly, when master craftsmen were depicted in portraiture from the later decades of the sixteenth-century-visual representations which were displayed in prominent chambers within guild halls - they were sometimes shown with their artisanal tools. ${ }^{66}$ A posthumous portrait of the master carpenter William Portington-former Master of the Carpenters' guild and royal Master Carpenter for half a century, from 1579 to $1629-$ presented this hugely accomplished artisan with the tools of his craft, dividers and ruler, in his hands. ${ }^{67}$ Based upon an original painting of 1626 , commissioned by Portington himself, this 1637 version was-according to a textual inscription at the base of the portrait-commissioned for display in the Carpenters' Hall, by another carpenter, Matthew Bankes, 'who served him 14 years'. ${ }^{68}$ The representation of this great guildsman with his workshop tools was a clear visual memorial of Portington's artisanal skills and achievements in life and his continued connection to the living arti-

62 Glover, Men of metal, 45.

63 MS 12105, f. 11.

64 MS 7110, f. 13v.

65 John Summerson, 'Three Elizabethan Architects', Bulletin of the John Rylands Library 40 (1987), 202-228.

66 Robert Tittler, The face of the city. Civic portraits and civic identity in early modern England (Manchester: Manchester University Press, 2007), 150-154.

67 Anthony Gerbino and Stephen Johnston (eds.), Compass and rule. Architecture and mathematical practice in England, 1500-1750 (New Haven and London: Yale University Press, 2009), 63 .

68 Tarnya Cooper, Citizen portrait. Portrait painting and the urban elites of Tudor and Jacobean England and Wales (New Haven and London: Yale University Press, 2012), 197. 
sanal community (including the commissioner, Bankes) who had trained within his workshops.

In late medieval and early modern London the livery halls were hugely significant sites for the memorialisation of eminent members. Through the donation of material artefacts to company buildings-and their subsequent use in the rites of the guilds-merchants and master craftsmen were able to shape their post-mortem reputations and legacies. Their material bequests reveal complex memory cultures, within which a wide range of qualities and achievements were valued. Guildsmen wished to be remembered as affluent charitable benefactors and men of honour, who comprehended the importance of company customs and the illustrious histories and patrons of their companies; they presented themselves as perpetual participants in convivial rituals and crucially, as masters of their respective artisanal practices. Though the break with Rome and discrediting of Purgatory undermined the traditional intercessory observances of living brothers on behalf of deceased members, later generations of guildsmen never forgot their fraternal obligations to remember their benefactors and uphold the reputations of the dead in the community of the living company. 
Erika Kuijpers, Judith Pollmann, Johannes Müller, and Jasper van der Steen - 978-90-04-26125-9 Downloaded from Brill.com04/26/2023 11:57:20AM via free access 
CHAPTER TEN

\title{
BETWEEN STORYTELLING AND PATRIOTIC SCRIPTURE. THE MEMORY BROKERS OF THE DUTCH REVOLT*
}

\author{
Erika Kuijpers
}

During the violent sack of the Brabant town of Tienen or Tirlemont in 1635, a maidservant of a burgher family who had fled the town was tied to a tree and raped by two Dutch soldiers from the army of Frederick Henry of Orange. The young woman cried so pitifully that the soldiers began to feel sorry for her, and, as a compensation for her loss of honour, both men proposed marriage; she just had to choose one of them. So the maid did. The maid and the soldiers congratulated each other with this happy ending and had a meal and drinks together. Moreover, she showed her future husband where her employers hid their silverware and subsequently ran away with him and the stolen treasure. The author who recorded this story concludes with the moral: never tell your servants where you hide your valuables. ${ }^{1}$

The author of this story was Johannes Jakinet alias Jean Jaquinet, an antiquarian or chronicler from Louvain, living in Tienen. He was about twenty years old when he witnessed the sack of Tienen by the Dutch and French armies in 1635. We know little about his identity, social status or office, but during his life he compiled a number of lengthy manuscripts on the history of the Netherlands and the Duchy of Brabant. ${ }^{2}$ He recorded personal memories and information from learned sources, pamphlets and popular books as well as tales and jokes he acquired from hearsay.

* Research for this article was funded by an NWO VICI grant for the research project Tales of the Revolt. Memory, oblivion and identity in the Low Countries, 1566-1700, and with support of the IAP project City and Society in the Low Countries, 1200-1850.

1 Royal Library Albert I Brussels, MS. 10245-6 'Chronijck van Nederlant (1523-1636)', ff. $195^{-195 v}$; The passage by Jakinet on the siege and plundering of Tienen in 1635 can also be read in transcription in: P. Kempeneers, 'Jan Jaquinet en de verwoesting van Tienen', Oost-Brabant. Heemkundig tijdschrift van het Hageland en omgeving 21 (1984), 16-29, there 26-27.

2 We know of two other manuscripts both in the Royal Library Albert I in Brussels: MS. 15938, Joannes Jakenet, 'Historie der Nederlanden onder de regering van Albertus en Isabella Philippus IV en Karel II. 1612 tot 1683, met bygevoegde portretten' and MS. 21769, Jan Jaquinet, 'Chronyke der Nederlanden (1500-1693)'. 
We do not know whether his texts circulated widely, but it is clear that he did his very best to entertain his intended audience. In the early modern period, history was meant to entertain as well as moralise: some stories were meant to amaze, others to horrify the reader. A good story articulated a clear message, a warning or a lesson, or if not, at least had to be funny.

For readers today, it is not completely clear what this particular story was meant to convey nor whether we are meant to believe it. We are amazed because this maid agrees to marry her rapist, but we cannot be sure that this would also have surprised a seventeenth-century audience. In any case that audience is likely to have been scandalised because the maid stole the family's silverware. The tale confirmed popular views on the proverbial untrustworthiness of housemaids. To us, the lack of reference to any source-had there been witnesses to the rape? - gives the impression that Jakinet merely recounted an urban legend. Yet he gave his story an air of historical realism by adding specific details about the protagonists. These were people that his local audience might have known about. He tells us that the maid was named Maria Iuliano, that she was a beautiful brunette, and that she was the daughter of the quarter master of the regiment of Ian de Velasco. Her employers, the owners of the house, were 'Ioncker' (Sir) Negrona and his wife 'Iouffrau' (Mistress) Backs who had fled with their children to Louvain. This family really existed. ${ }^{3} \mathrm{He}$ also notes that Maria should not bear all the blame because she should not have been left alone and she had fought to defend her virginity. Jakinet does not explicitly mention his source, but it is likely that he knew this story from hearsay. Orally transmitted anecdotes can be recognised by their funny or unexpected plots and by their normative message, for instance through recounting the consequences of a transgression of norms and values. Although they may refer to a narrative context or common history that is familiar to the audience, they usually lack external information such as details about time, place and people that do not matter to the plot. Narrative structuring is essentially a process that gives meaning to events by identifying their role in and contribution to an outcome. ${ }^{4}$ During the structuring of narratives in plots details are omitted; some

3 Paul Kempeneers located the house of the family Negrona where the event should have taken place. Paul Kempeneers, Thuis in Thienen (Tienen: Orientaliste, 1999), 357-359.

4 Donald E. Polkinghorne, 'Narrative psychology and historical consciousness. Relationships and perspectives', in Jürgen Straub (ed.), Narration, identity, and historical consciousness (Oxford and New York: Berghahn Books, 2005) 3-22, there $5^{-6 .}$ 
parts of the story will be condensed while others need to be sharpened or accentuated. Over time the storyteller will also get rid of inconsistencies and loose ends, while external, context-dependent information gets lost. ${ }^{5}$ Once younger generations start to write down the tales they have heard from their parents and grandparents, the lack of historical detail in oral accounts may become a problem.

Seventeenth-century histories were expected to contain some references, facts and figures in order to be received as truthful. There are many ways to solve that problem. The simplest and a very common one is for the author to acknowledge that this is a story that he or she got from hearsay. Seventeenth-century authors often state that they heard their stories from old people. This is a way to say that there might be some truth in the tale as these old people had witnessed the events themselves, but, at the same time, such a disclaimer prepares the audience for a specific genre of story. Like Jakinet, authors may also try to recontextualise the story by adding details like names, places, exact data, etc. Usually they would enrich the text with their own historical knowledge: they place the story in a broader historical context and connect it to a specific time and location. Yet, the internal 'smoothing' of the story-the 'flattening', stereotyping and rationalisation that has taken place during oral transmission-cannot be undone. That is why orally transmitted stories often remain recognisable to the attentive reader.

The extraordinary experience of war was a rich source of inspiration for storytellers, as several chapters in this volume illustrate. Families and local communities were the bearers of memories shaped in tales that could easily be transmitted from one generation to the next during long winter nights at the fire. Today as well as in the sixteenth and seventeenth centuries orally transmitted memories play a constituent role in identity formation of social groups. Recalling extraordinary war tales of suffering, victory, escape, salvation and heroism, and narrating them is a way of belonging and being part of the family's or community's history. Therefore people usually care about the stories' preservation and become worried if their bearers are getting old and dying off. The boom in memory studies of the past decades has shown that orally transmitted memory has a lifetime of up to three generations. At the moment when the communicative memory of the past threatens to come to an end because of the passing away of one's elders, the children or grandchildren start writing the tales

\footnotetext{
5 Ibid., 9.
} 
down. In the scholarly terms developed by Aleida and Jan Assmann, this is the moment when communicative memory turns into cultural memory. ${ }^{6}$

The transformation of communicative memory into cultural memory can also be observed three generations after the Dutch Revolt. From about the 1640 , seventy to ninety years after the early violent phase of the Revolt in the 156 os and 1570 , there was a rise in memory activity. In the Northern Netherlands the disappearance of the war generation coincided with the Peace of Westphalia that was celebrated fairly extensively. ${ }^{7}$ Yet the local memory that flourished around the mid-seventeenth century does not seem to be related to that event. Its focus is on the heroic exploits of locals. Between 1640 and 1660 we see a growing number of local histories of the Revolt, often written by occasional or second-rate authors, who include in their volumes previously unpublished stories that seem to derive from local oral tradition. Many of their prefaces state that the authors felt a need to write these histories down because they were at risk of being lost to oblivion. ${ }^{8}$

This chapter explores how the authors of such local histories tried to merge oral tradition with the 'patriotic scripture' that had emerged in the historical literature in the decades before. ${ }^{9}$ They seem to have functioned as brokers between overlapping yet distinctive mnemonic communities. The historical canons that had developed in both the Northern and Southern Netherlands offered a highly charged but also quite generic tale of collective suffering and struggle, which demonised the enemy and affirmed the unity and religious and/or moral superiority of the people in one's own camp. ${ }^{10}$ At first sight the local tales recorded after 1640 did not

6 Jan Assmann, 'Communicative and cultural memory', in Astrid Erll, Ansgar Nünning and Sara B. Young (eds.) Cultural memory studies. An international and interdisciplinary handbook (Berlin and New York: De Gruyter, 2008), 109-118; Aleida Assmann, Der lange Schatten der Vergangenheit. Erinnerungskultur und Geschichtspolitik (Munich: C.H. Beck, 2006), 28.

7 Simon Groenveld, T'is ghenoegh, oorloghsmannen. De Vrede van Munster: de afsluiting van de Tachtigjarige Oorlog (The Hague: Sdu Uitgevers, 1997); Mieke B. Smits-Veldt, 'De viering van de Vrede van Munster in Amsterdam. De dichters Geeraardt Brandt en Jan Vos bevestigen hun maatschappelijke positie', De Zeventiende Eeuw 13 (1997), 193-200.

8 See for example: Arnoldus van Duin, Oudewaters moord. Of waerachtig verhael van d'oudheid, belegering, in-nemen en verwoesten der geseide stad. (Oudewater, 1669), f.A1.

9 The term patriotic scripture was coined by Simon Schama, The embarrassment of riches. An interpretation of Dutch culture in the golden age (London: Collins, 1987), Chpt. 2.

10 Jasper van der Steen, 'Goed en fout in de Nederlandse Opstand', Holland: regionaalhistorisch tijdschrift 43 (2011), 82-97; Judith Pollmann, 'No Man's Land. Reinventing Netherlandish Identities, 1585-1621', in Robert Stein and Judith Pollmann (eds.), Networks, regions and nations. Shaping identities in the Low Countries, 1300-1650 (Leiden: Brill, 2010), 241-262; 
meet the moral standards laid down by those patriotic scripts. They did not mention suffering or the ideals of freedom or the true religion as a motivation for the deeds of local heroes. The first section of this chapter summarises the problematic development of public memory after a civil war and the rise of canonic scripts in both the Northern and Southern Netherlands. The second section discusses two narratives of local heroism in the Northern Netherlands, while the third deals with an example from the region of Douai in the Southern Netherlands.

\section{Contested Memories of a Civil War}

In 1566, the seventeen provinces of the Low Countries, ruled by the Habsburg King of Spain, Philip II, became involved in a civil war that officially ended with the recognition of two separate states in 1648: the Dutch Republic in the North and the Habsburg Netherlands (more or less equivalent to today's Belgium) in the South. The persecution of Protestants combined with the centralizing policies of the regime had triggered a rebellion among a part of the nobility, nicknamed Gueux or 'Beggars', who were supported by a growing number of towns. In 1572, the Habsburg governor-general, the duke of Alba, began a violent military campaign to force the rebel cities to surrender. If they did not open their gates to the Spanish troops instantly, they were put to the sack. To punish the rebels Alba's soldiers were given free rein to plunder, and hundreds-sometimes thousands - of men, women and children were murdered or died trying to escape. The memory of these episodes could be contested. In most towns that joined the rebellion in 1572, the citizens had been intensely divided, between Protestantism and the old faith and between loyalty to the king and loyalty to the rebel leader William of Orange. Often, groups among the civic militia had opened the gates to the rebels against the will of a part of the ruling elites and the population. In some places religious strife had led to violence within the urban community. Between 1578 and 1584 religious polarisation in a number of Brabant and Flemish towns, including Ghent, Bruges, Malines and Antwerp, led to the emergence of Calvinist theocracies (the so-called Calvinist Republics), in which the Catholic

Judith Pollmann, “"Brabanters do fairly resemble Spaniards after all”. Memory, propaganda and identity in the Twelve Years' Truce', in Judith Pollmann and Andrew Spicer (eds.), Public opinion and changing identities in the early modern Netherlands. Essays in Honour of Alastair Duke (Leiden: Brill, 2007), 211-228. 
clergy and sometimes also lay citizens were harassed or expelled. ${ }^{11}$ In a place like Den Bosch, by contrast, Protestants were chased out of town by the Catholic civic militia in $1579 .^{12}$ In towns like Leiden and Haarlem, besieged by the Spanish army for months, the population suffered from food and fuel shortages and an outbreak of pestilence as well the continuous stress of threats of attacks. Other places had to bear the costs of garrisoning the troops of one side or the other. In the countryside, life was particularly unsafe. The population had to deal with both rebel and Spanish troops, who exhausted resources where they did not simply pillage and completely burn down the villages. ${ }^{13}$

Newsprints, pamphlets and songbooks about the conflict circulated widely from early on. Local histories had begun to appear very soon in larger towns, and from around 1600 the first 'national' histories of the conflict were also being published. ${ }^{14}$ Eventually smaller towns also got their histories. Most of these texts focused on political and military history. Local events like the sieges of Leiden, Haarlem and Alkmaar were also commemorated in annual ceremonies, sermons, plays, monuments, and art works in public. ${ }^{15}$ The commemoration of the war as a Netherlandish conflict was boosted in the years between 1600 and 1620 when debates about the continuation of the war and the relation between state and

11 Guido Marnef, Het Calvinistisch bewind te Mechelen, 1580-1585 (Kortrijk-Heule: UGA, 1987); G. Marnef, 'Brabants calvinisme in opmars. De weg naar de calvinistische republieken te Antwerpen, Brussel en Mechelen, 1577-1580', Bijdragen tot de geschiedenis 70 (1987), 7-21; Johan Decavele (ed.), Het eind van een rebelse droom. Opstellen over het calvinistisch bewind te Gent (1577-1584) en de terugkeer van de stad onder de gehoorzaamheid van de koning van Spanje (17 september 1584) (Ghent: Stadsbestuur Gent, 1984); Judith Pollmann, Catholic identity and the Revolt of the Netherlands, 1520-1635 (Oxford: Oxford University Press, 2011), 113-124.

12 Jozef A.M. Hoekx, Vruchten van de goede en de slechte boom. Heyman Voicht van Oudheusden over de godsdiensttwisten in zijn stad's-Hertogenbosch en in Breda (1577-1581) (Den Dungen: Tilia Levis, 2008).

13 Leo Adriaenssen, Staatsvormend geweld. Overleven aan de frontlinies in de meierij van Den Bosch, 1572-1629 (Tilburg: Stichting Zuidelijk Historisch Contact, 2007).

14 The first histories of the Revolt in the Netherlands appeared in the late sixteenth century: Pieter Bor, Oorspronck, begin ende aenvang der Nederlantscher oorlogen, beroerten ende borgerlijcke oneenicheyden.... (Utrecht, 1595); Emanuel van Meteren, Belgische ofte Nederlantsche historie, van onsen tijden.: Inhoudende hoe de Nederlanden aenden anderen ghehecht, ende aen Spaengien ghecomen zijn ... Meest onder de regeeringhevan Philippus de II. coninc van Spaengien, tot synen doot, ende den vvtgaenden iare 1598. (Delft, 1599); Bernardino Mendoça, Commentaires mémorables des guerres de Flandres et Pays Bas depuis l'an 1567 jusques à l'an 1577: avec une sommaire déscription des pays bas (Paris, 1591).

15 Judith Pollmann, Herdenken, herinneren, vergeten. Het beleg en ontzet van Leiden in de Gouden Eeuw (Leiden: Primavera Pers, 2008); Judith Pollmann, Het oorlogsverleden van de Gouden Eeuw (Leiden: Universiteit Leiden, 2007). 
church had created a canonic popular patriotic narrative of the Revolt. ${ }^{16}$ Many publications in this period served as war propaganda. The party that opposed a peace with Spain tried to unify the population and bolster its arguments by stressing the collective experience of suffering, struggle and victory in the name of freedom. The Black Legend about Spanish tyranny proved an effective instrument in their war propaganda. ${ }^{17}$ An important element in this narrative was the innocence of the victims versus the 'barbarian cruelty' of the Spanish perpetrators. The anonymous victims were always depicted as harmless and defenseless: virgins, children, old people, pregnant women, and unborn babies. Some pictures referred to the biblical massacre of the innocents. The hanging of a pregnant woman in her doorway became an iconic theme in the history of the Dutch Revolt. ${ }^{18}$

Conditions for public memory practices were very different in the Southern Netherlands, parts of which 'reconciled' voluntarily with their Habsburg rulers, while others were reconciled by force. By 1585 , when the city of Antwerp fell to Alexander Farnese, all Calvinist bulwarks in the South had been captured by the Habsburgs and thousands of families of reformed citizens and sympathisers left for the North. While the Calvinist exiles in the North developed a narrative that recalled the example of the Israelites and their flight to Egypt, those who stayed home and reconciled with the regime and the Roman Catholic Church had to keep their memories private. ${ }^{19}$ All treaties by which provinces and cities were 'reconciled' with the King contained an article in which it was agreed that the past would be forgotten, an act of oblivion which was effectively a full

16 Carolina Lenarduzzi, “De oude geusen teghen de nieuwe geusen”. De dynamiek van het oorlogsverleden ten tijde van het Twaalfarig Bestand' Holland: regionaal-historisch tijdschrift 43 (2011), 65-81. See also chapter 2 by Jasper van der Steen in this volume.

17 Wolfgang Cilleßen, 'Massaker in Der Niederländischen Erinnerungskultur. Die Bildwerdung Der Schwarzen Legende', in Christine Vogel (ed.) Bilder des Schreckens. Die mediale Inszenierung von Massakern seit dem 16. Jahrhundert (Frankfurt am Main: Campus, 2006), 93-135; K.W. Swart, 'The Black Legend during the Eighty Years War', in J.S. Bromley and E.H. Kossmann (eds.) Britain and the Netherlands (The Hague, 1975). Also very influential was a history book for children: Willem Baudartius, Spieghel der ievcht, ofte corte Cronijcke der Nederlantsche geschiedenissen: In de welcke...verhaelt...worden, de voornaaemste Tyrannien ende... wreedtheden, die door het beleydt der Coningen van Hispaengien... in Nederlandt bedreven zijn ... (Amsterdam, 1615).

18 Erika Kuijpers, 'The creation and development of social memories of traumatic Events. The Oudewater massacre of 1575', in Michael Linden and Krzysztof Rutkowski (eds.) Hurting memories and beneficial forgetting. Posttraumatic stress disorders, biographical developments, and social conflicts (London: Elsevier, 2013), 191-201.

19 See chapter 15 by Johannes Mueller in this volume. 
amnesty. ${ }^{20}$ This obligation to forget may also have stopped former Protestants or sympathisers in rebel towns like Bruges, Ypres, Ghent or Valenciennes from talking about their past. We have not found many manuscripts from this group that reveal their former sympathies. The absence of memory practices in the public sphere must have marked the identity of the former Protestant generation who remained in the South. Yet many in the population in fact welcomed the return of their legitimate overlord in the hope that the troubles would come to an end for good and that the Catholic religion would be protected. This is at least the sentiment that was expressed in many chronicles at the time. ${ }^{21}$ Soon, authors of local and regional histories and chronicles, many of whom belonged to the Catholic clergy, remembered the 'troubles' as a short and regrettable interruption of a continuous history of loyalty and piety: a test, as it were, of the true believers. Fortunately, with the help of the Virgin Mary and God, the heretics had been chased away and society was cured of its evils. Many of these accounts stress continuity. By contrast, we know very little about the social memory of the local populations. Still many people must have had memories that sat uncomfortably with this Counter-Reformation narrative of their past. Moreover, the works of local historians and antiquarians usually remained unpublished, like the collections of Jakinet. Their contents, however, give the impression that they functioned just as they did in the Dutch Republic, as brokers between popular memories, oral tradition and a canonic version of the past that focused on church and state as the best guarantors of religious orthodoxy. ${ }^{22}$

\section{Freebooters in the Reed. The Northern Netherlands}

In the local oral tradition in the North, narratives tended to be either miraculous or entertaining. There was something very spectacular about the success of the Revolt in the northern province of Holland. The first years of civic resistance and the guerilla tactics of the rebels, in particular, captured the imagination. Many successes were the fruit of cunning schemes and tricks. There are tales of attacks on Spanish troops by soldiers

20 Violet Soen, 'Reconquista and reconciliation in the Dutch Revolt. The Campaign of Governor-general Alexander Farnese (1578-1592)', Journal of Early Modern History 16 (2012), 1-22; Pollmann, Catholic identity, 126.

21 Pollmann, Catholic identity, 140-142.

22 Ibid., $165^{-173 .}$ 
hidden in peat barges and beer barrels or disguised as farmers' wives. ${ }^{23} \mathrm{~A}$ very prominent role in many stories is assigned to the watery landscape that was used by the Hollanders to their advantage. While the very wet soil posed a major logistic problem for the Spanish troops with their heavy cannon, the locals could swim and were agile with boats and on skates. They crossed fields intersected by ditches and canals by jumping across them with poles. Thus the rebels could escape from the Spaniards by hiding in the fringes of reed, luring the enemy into ambushes, getting away much faster or smuggling messages hidden in a pole between the besieged towns and the rebel forces. Indeed the first rebel successes-the Beggar's invasion in Den Briel in 1572, the relief of Alkmaar in 1573 and of Leiden in 1574-were achieved through the inundation of the countryside.

Many families were proud of the wartime past of their grandfathers and -mothers. A heroic or celebrated ancestor could add lustre to the reputation of the entire family. There are numerous examples of elite families especially, who successfully promoted their ancestors' illustrious deeds. A good example is the story of Jan Pieterszoon van der Lee from the Holland town of Oudewater. Oudewater was captured, sacked and burnt down by the Spanish army in 1575. Around 1660, when Arnout or Arnoldus van Duin, a local grocer, started to write a history of this event, he relied on what he had heard 'from old people who heard these stories many times from their ancestors' and 'from people whom I have known and whom I have spoken with myself, who have a good knowledge of the events and who were already seventeen years old at the time'. ${ }^{24}$ Some of his sources had told him their family stories. One of them must have been a relative of Jan Pietersz. van der Lee $\left(1545^{-1613}\right)$ who as a young man had joined the Beggar army at sea in 1572 . He was an excellent warrior, Van Duin writes, and there were so many stories about him that it would be impossible tell them all. ${ }^{25}$ Van der Lee was born into a leading family of rope-makers (Oudewater was known for the cultivation of hemp and the rope-making industry). Jan was elected alderman and was a captain of the civic militia. ${ }^{26}$

23 Many of these popular heroic stories were collected and published by a relatively unknown author named Petrus de Lange, Batavise Romeyn: ofte Alle de voornaemste heldendaden, ridderlijke feyten en listige oorlogs-vonden, in veld en zeeslagen, overwinninge van steden en schepen, en in andere gelegentheden, by de Hollanders en Zeeuwen verricht, zedert 1492 tot 1661 (Amsterdam, 1661).

24 Van Duin, Oudewaters moord, 32.

25 Ibid., 29.

26 Nettie Stoppelenburg, De Oudewaterse moord (Oudewater: Stichting Cultureel Sociaal Fonds Mooyman-Martens, 2005), 28-29. 
During the siege of Oudewater in 1575 he played an important role in the defence of the town. However, the defenders had to yield to superior numbers, and the rebellious town was sacked and many inhabitants killed as punishment. Jan Pieterszoon Van der Lee suffered a leg wound and was caught, but after he promised to pay a ransom, his life was spared. In the Spanish camp he found his good old friend Leendert Ariensz. van Dam among the other prisoners. After Van Dam convinced the Spanish soldiers that someone in a nearby town owed him a large sum, they gave him three days to collect the money, meanwhile holding Van der Lee as a hostage. Yet Van der Lee urged Van Dam not to return. He then persuaded the Spaniards that two thousand guilders were buried in the yard of the house of his uncle. When two soldiers accompanied him to his uncle's house he pretended to be so severely wounded that he could hardly walk. At the house one of the soldiers went looking for a spade, and Van der Lee knocked down the other and escaped over a fence.

Van Duin does not spare his readers the gory details. During Van der Lee's flight, the flesh was hanging loose from his injured foot so he cut off the flapping tissue himself. Once, in accordance with their plan, he was reunited with his friend Van Dam in a neighbouring town, the two men, now penniless, decided to earn their living as porters in the town of Gouda. During this period the countryside around Gouda was particularly unsafe because of the deserters from the Spanish forces prowling around. The town of Gouda put up a prize of fifty guilders for each soldier taken prisoner and brought to town. Van der Lee killed one in ambush and cut off the poor man's head. 'Yet, because the head was bald, and he could not carry it by its hair, he had to take it to town with his fingers in the mouth to the great amazement of the people who saw him pass by'. In 1578, Van der Lee returned to Oudewater and took up his old craft of rope-making again. He was again chosen alderman and later was elected burgomaster. At the time of his death in 1613 he was a well-to-do man of distinction.

For the Van der Lee family this tale must have been a satisfactory narrative. Their grandfather had been fearless, clever and persistent. Through his hard work the family's rope yard became a flourishing enterprise that still exists today. ${ }^{27}$ The story was exciting, spectacular and funny, as well as a little gruesome. Yet, these elements were not sufficient to secure Van der Lee a place as a national hero in the historiography of the Revolt in

27 http://www.touwfabriekvanderlee.nl/touwfabriek/historie, consulted on 15 February 2013 . 
subsequent ages. Perhaps the family could have done more to spread the fame of their forefather. The case of a famous burgomaster of Leiden shows that good stories about individual heroism could develop retrospectively. Burgomaster Van der Werf's heroic offer of his own flesh to the starving population of Leiden was probably invented well after the siege had been lifted but that did not stop it from becoming one of the most famous stories in the history of the Revolt. ${ }^{28}$ The tale of Van der Lee contains no mention of self-sacrifice and no clear signs of piety or godliness. In the book by Van Duin, however, the context of the suffering of the Oudewater population helps to turn Van der Lee into an exemplary patriot nevertheless.

Oral traditions of the Revolt did not always match the moral standards of the narrative templates of suffering and courageous self-sacrifice for freedom, religion or fatherland. In an area north of Amsterdam, called Waterland, local farmers and freebooters in the 1570 s attacked Spanish convoys on both land and water in order to claim the material proceeds that helped their families to survive and the rebels to continue the military resistance. The royal army had great difficulties getting this area under control. It was of strategic importance as it bordered the waterway between Amsterdam, loyal to the king, and Haarlem, a rebel city that was besieged in 1573. The guerrilla war waged in this region generated many popular stories. Just as in Oudewater, however, it took a long time before a local historian began to write them down. Hendrik Jacobszoon Soeteboom, alias Soet, born in 1615, was the son of an innkeeper in Zaandam, a small town north of Amsterdam. Here he went to school, managed to learn Latin, and opened a bookshop. From 1640 onwards he started to publish works on the local history and archaeology of the area around Zaandam and Waterland. ${ }^{29}$ In his Zaanlandze Arcadia, first published in

${ }^{28}$ Jori Zijlmans, 'Pieter Adriaensz. van der Werf. Held van Leiden', in Joris van Eijnatten, Fred van Lieburg and Hans de Waardt (eds.), Heiligen of helden. Opstellen voor Willem Frijhoff (Amsterdam: Bert Bakker, 2007), 130-143.

29 Soeteboom was very productive and wrote a number of regional histories as well as theatre plays. For example: Hendrik Soeteboom, Vroonens begin, midden en eynde, met het opkomen der steden van West-Vrieslant, waer in nevens andere dingen te vinden is de alder oudtste en voornaemste geschiedenissen van West-Vrieslant tot aen de val van hare oude hooftstadt Vroonen, met het opkomen der steden Hoorn, Enckhuysen, Alckmaer en Medenblick, en de bloedige oorlogen, tusschen de Hollanders en kleyne Vriesen, tot het jaer 1303, alles in 4. boecken (met vlijt) by een vergadert en met kopere platen verciert (Amsterdam, 1661); Hendrik Jacobsz Soeteboom, De historie van Waterland: behelsende de oude, besondere en ghedenckwaerdige geschiedenisse van Waterlandt en de Waterlanders: mitgaders de steden van Edam, Munckendam, en de alle dorpen van Waterlandt: als mede een breede en generale 
1650, he also wrote about the impact of the war in this area in the years $1572-1578.30$

The book is a curious mixture of poorly matched ingredients. Just like Van Duin in Oudewater, Soeteboom had clearly read and used the work of several well-known historians of the Revolt, including local histories of nearby Haarlem and Hoorn. Furthermore he reported on his findings in the archives of the local magistrates, where he retraced political decisions as well as the financial administration of the payments for garrisons and labour for defence works for instance, uncovering a war economy in detail. But a large part of his narrative consists of stories which older people had told him. His own grandfather seems to have been one of his sources. ${ }^{31}$ That his sources were local can be surmised from the fact that so many people and locations are precisely named.

Here is a typical story about the activities of the freebooters which Soeteboom heard from an old farmer who was working on the land near Amsterdam. During the siege of Haarlem a number of Spanish soldiers sailed from Amsterdam to the Spanish camp outside Haarlem. When the Spaniards came ashore for a break, as the weather was nice, the freebooters emerged from their hiding places and killed them all. They cut off the noses and ears and pinned them on their hats.

On another occasion, when the freebooters in Waterland had run out of money after having been drinking at an inn, they headed for the village of Assendelft, still in the hands of the royal troops. There they went to the house of a rich single woman, whom they lifted from her bed and carried off into their boat in order to force her to pay a ransom for her freedom. On the way her nightgown was torn from top to bottom. She cried and screamed, complaining that they did not want her for her body but just for the money. One of the men piously covered her with his own cloak. There were many accounts like this, funny as well as wondrous, and some cruel. Soeteboom mentioned one occasion where the freebooters cut off the private parts of the enemy captain they killed and brought them home as a trophy. He added that he was ashamed to tell this story, yet apparently these actions were understandable and acceptable in the extreme context of warfare and perhaps also excused by existing template of Spanish inhuman cruelty and oppression. Soeteboom's book and the

beschrijvinge van 't begin, opgangh en voortgangh der stadt en heerlijckheyt van Purmer-endt (Amsterdam, 1660).

${ }^{30}$ Hendrik Jacobsz. Soeteboom, Zaanlandze arcadia in vyf boeken verdeelt (s.l., 1650).

31 Ibid., $45^{2}$. 
tales that he told have subsequently been forgotten. Only one Waterland hero entered the national history books, although the origin of this story is a mystery according to historians who have tried to identify the protagonist. ${ }^{32}$ This is a story that qualifies as a moral lesson. ${ }^{33}$ When the royal troops were approaching the village of Westzaan, a young peasant left his belongings behind and put his old mother on a sledge and brought her all the way over the ice from Waterland to the town of Hoorn. In Hoorn the magistrates commemorated this event by commissioning a wooden sculpture above one of the town gates with the following text:

When the state and Westzaan sighed under tyranny

This brave son saved his mother from death

And flew to this place in this manner

Thus a noble child shows his loyalty to his parents in times of need ${ }^{34}$

\section{Heretics in the Woods: Southern Netherlands}

In the very south of the Netherlands, in the area between Lille, Tournai, Valenciennes and Douai, Calvinist preachers attracted huge crowds in the summer of 1566, and many 'petites nobles' here were among the supporters of the new faith. ${ }^{35}$ After a wave of iconoclasm erupted in August in Steenvoorde, the violence spread rapidly to the east as well. The Catholic bulwarks of Lille and Douai were saved, yet Tournai and Valenciennes and many other towns in the area were heavily damaged by the imagebreakers. The government of Valenciennes, the 'new Geneva', was practically taken over by the Calvinist consistory in the autumn of 1566 , but it was reconquered and punished by Philip of St. Aldegonde, the baron of Noircarmes a few months later. ${ }^{36}$ The area remained in turmoil until peace and order were restored by the end of the 1570s. In many towns

32 G.J. Honig, 'Lambert Melisz. van Westzaan en zijn nageslacht te Hoorn', De Zaende. Maandblad gewijd aan de historie, folklore en genealogie van de Zaanstreek (1948), 324-334; Simon Hart, 'Lambert Melisz. De huisman van Westzaan?', West-Friesland's 'oud en nieuw' 24 (1957), 54-59.

33 Soeteboom himself devoted a play to this theme: Hendrik Jacobsz Soet, Batavische Eneas, of getrouheyts voor-beelt, nevens de verwoestinge van West-Zanen ende Crommenije, geschiet anno 1574. Treur-spel (Alkmaar, 1645).

34 Simon Hart, 'Lambert Melisz.', 54.

35 Alain Lottin and Philippe Guignet, Histoire des provinces Françaises du Nord. De Charles Quint à la Révolution française (1500-1789) (Arras: Artois Presses Université, 2006), 73-80.

36 Ibid., $87-90$. 


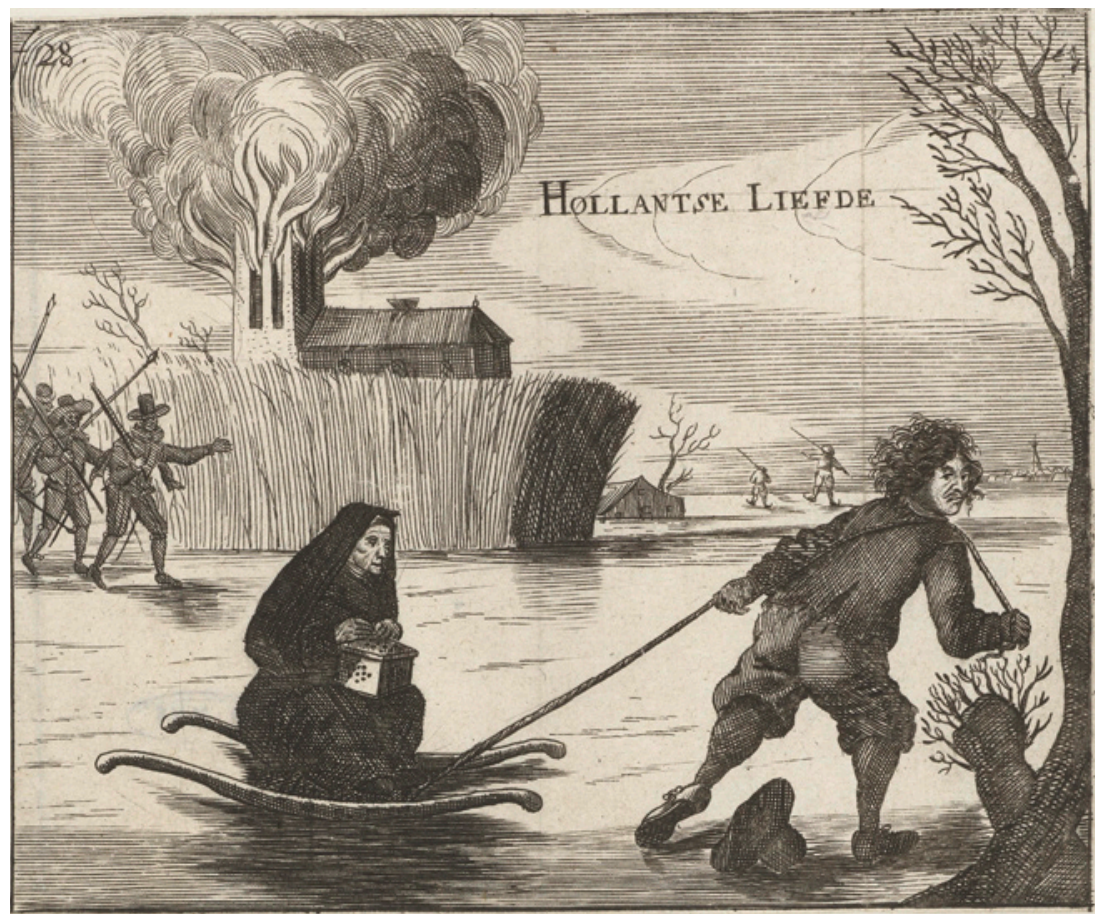

Fig. 10. Lambert Melisz saves his mother from plundering soldiers. Anonymous print 1659-1661, Rijksmuseum Amsterdam.

in this region chroniclers wrote of the history of the troubles as a closed chapter. Few of those works were published at the time; one exception is the history of Tournai published by canon Jean Cousin $(† 1636)$ in 1619. In this voluminous work a thousand years of history since the first Christians and early medieval times serve to demonstrate the venerable antiquity and authority of the Catholic Church in Tournai as well as its constancy in times of troubles over the centuries. The second volume bears a dedication to Charles de Lalaing, the count of Hoogstraten, in which the author expresses his hope that the last Calvinists in Tournai would be convinced by this long history of miracles and devotion, all the more so because heretics could not boast any miracles of their own. ${ }^{37}$

37 Jean Cousin, Histoire de Tournay, ou Quatre livres des chroniques annales, ou demonstrations du christianisme de l'évesché de Tournay... (Douai, 1619); There is also a later edition of the works edited by the Société Historique et Littéraire de Tournai: Jean Cousin, Histoire de Tournay, (Tournai: Malo et Levasseur, 1868) vol. II. 
In the last chapters Cousin finally treats the troubles of 1566 . There he mentions the fact that many farmers in and around Douai remained des bonnes catholiques thanks to a course of events which had unfolded on the morning of 26 August. After iconoclasts had pillaged the churches of Marchennes, farmers directed by one Fery de Guyon (1507-1567), the bailiff of Anchin, hunted down a group of 'heretics' in the woods and 'cut them into pieces'. The following day fights were again reported during which many Calvinists were killed. ${ }^{38}$

Fery de Guyon had been a soldier who spent a long career in the service of Charles V. He had served in the Italian wars, was present at the sack of Rome in 1527 and was later promoted to the archers du corps of the king. He became bailiff of Anchin shortly after the Peace of Cateau-Cambrésis in 1559. At some point he had married a girl from Tournai, Jeanne de Saint Raagon, and had returned to the region every now and then, having nine children with her. When he settled down for good in the town of Pecquencourt near Douai, he started to write his memoirs, a cheerful tale of many adventures. Just as in many other contemporary soldier memoirs he mainly reports on the military aspects of war and very little on his personal experiences. Expressions of emotions and piety are rare. ${ }^{39}$ Here is his account of the events of August 1566: On Sunday 25 August about four or five hundred men ransacked the church of Marchiennes as well as, 'unreasonably, the houses of monsieur Buret et monsieur Magaret'. That evening De Guyon met the prelat of the Abbey of Anchin in the town of Pecquencourt, who was on his way to seek refuge in Douai because he feared that the vandals would soon visit Anchin, 'if God would not intervene'. 'I answered laughing that our sins were the cause'. ${ }^{40}$

De Guyon returned to his home in Pecquencourt, where he found the assembled community on the market place in an agitated mood. But De Guyon 'answered them smiling (tout en riant) that God would give a remedy'. ${ }^{41}$ Then De Guyon mounted his horse again and visited several villages in the neighbourhood and mobilised a good number of peas-

38 Cousin, Histoire de Tournay, vols. 3-4 (Tournai: Malo et Levasseur, 1868), 316.

39 For the differences in the representation of individual experience in pre-modern and modern memoirs see the work of Yuval Noah Harari, Renaissance military memoirs. War, history, and identity, 1450-1600 (Woodbridge: Boydell Press, 2004); Yuval Noah Harari, 'Martial illusions. War and disillusionment in twentieth-century and renaissance military memoirs', Journal of Military History 69 (2005), 43-72.

40 Fery de Guyon, Mémoires de Fery de Guyon, ecuyer, bailly général d'Anchin et de Pesquencourt, ed. A.P.L. de Robaulx de Soumoy (Brussels: Heussner, 1858), 145-150.

41 Ibid., 146. 
ants who promised to come to his assistance at the ringing of the big bell of Pecquencourt. The next morning, before dawn, the bell rang, and with about 700 men and 24 horses they marched in the direction of Marchennes. They took Marchennes and chased the heretics out of town. And although De Guyon subsequently gave a sign to retreat, afraid that the rebels would ambush his men in the woods, many men pursued the Calvinists nevertheless. In total they killed about 70 or 80 of them. Back in Anchin, they were treated to a rich meal with beer, cheese and bread. Yet in the afternoon a preacher with 400-500 followers had again returned to Marchennes, and now the whole population was up in arms. Again the bells rang and the men chased the Calvinists in the direction of Brillon. There, they encountered the seigneur of the neighbouring village of Warling and his company, who again killed many 'sectarians', almost as many as had been killed in the morning. "This was the first defeat of the sectarians, we pray that the Almighty is contented, we have done this in the service of the king and the commonwealth', De Guyon concludes. ${ }^{42}$ In the next chapter he describes how he was rewarded for these exploits with a horse from the stables of Margaret of Parma and a sum of 50 écus.

The memoirs of Fery de Guyon were published in 1664 by his grandson Pierre de Cambry, who was a canon in Tournai. ${ }^{43}$ The publication is dedicated to Count Philip of Egmont. The central motive for publication according to the dedication was to make known the exploits of this old soldier in the summer of 1566 . The grandson apologises for the patois used in the memoirs, as they were written by a humble servant of the king, but considering 'his zeal to the extinction of the infidels and other enemies to the Catholic faith', De Cambry is confident that the reader will forgive De Guyon his naivety. By way of extra proof of the truth of this story he has added at the end of the book a song (chanson de joye) that the farmers in and around Pecquencourt 'passed on from father to son and are still singing today as they learned it from their ancestors' ${ }^{44}$ Pierre de Cambry believed that the deeds of his grandfather had brought blessings upon the family as a whole. At the end of the memoirs he added some genealogical details of the family and especially of the life of his eldest sister, Jenne

42 Ibid., 150.

43 Fery de Guyon, Les mémoires non encor veues du sieur Fery de Guyon... contenant les batailles, sièges de villes, rencontres, escarmouces, où il s'est trouvé, tant en Afrique, qu'en Europe pour l'empereur Charles V\& Philippe II roy d'espagne, son fils de glorieuse mémoire, ed. P. de Cambry (Tournai, 1664).

44 Ibid., f. A3v; see also the appendix at the end of this chapter. 
de Cambry, who was an Augustinian nun in Tournay and Lille where she died in an air of sanctity in 1639 at the age of 58 :

To whom our good God bestowed so many graces and heavenly favours that one may piously believe that this has been in reward of the services which her grandfather rendered to the Catholic faith by his arms and honour, which was also noted by lord provost Mr. André Catullus and Mr. Jacques Groulard the treasurer, canons of the collegiate church of Renaix, as censors in their approbation of these memoirs by Mr. De Guyon, who is now with God. ${ }^{45}$

\section{Conclusion}

The local memory of the glorious deeds of Fery de Guyon fitted beautifully with the Counter-Reformation rhetoric of the works of authors like Cousin. He represented an ideal of militant Catholics who risked their lives to destroy heretics. Although De Guyon himself in his memoirs focuses on the material rewards his adventures brought him, his grandson apologised for the 'naivety' of the narrative and stressed the godliness of De Guyon's deeds and the eternal rewards for his descendants. Apparently it was not so difficult to connect the 1566 killings of Calvinists with a long history of Catholic zeal.

The extraordinary exploits of the war generation were deployed to embellish the war record of families in the Northern Netherlands as well. In the oral tradition a connection with a grand narrative of patriotic struggle for freedom or a true faith may not have been explicit, but local authors could still present these stories within that context. In a recent article on the lifecycle of myths, Judith Pollmann argues that stories from oral tradition would continue to thrive 'only when they were framed historically and/or supported by material evidence'. She demonstrates that historians and antiquarians are usually the main providers of that evidence. ${ }^{46}$ And indeed, Jakinet gives us the names of the maidservant who was raped, as well as the name of her master, while Pierre de Cambry offers evidence for the significance of the acts of De Guyon by adding a variety of details: the song 'that is still sung to date', the story of the saintly life of his sister, and the authority of the censors. Arnoldus van Duin and Hendrik Soeteboom

45 Ibid., 165 .

46 Judith Pollmann, 'Of living legends and authentic tales. How to get remembered in early modern Europe', Transactions of the Royal Historical Society, 6th series 23 (forthcoming 2013). 
contextualise the local narratives with historical data they derived from respected and well-known historians, with archival material (Soeteboom) and by naming many eye witnesses (Van Duin). Thus they compensate for the loss of external data during the process of smoothing and flattening typical of oral transmission. Still, a good plot remains essential for the longevity of tales. And such a plot had to meet certain moral standards if it was to survive in the ages to come. It is typical that the only story from Waterland that found its way into the developing national histories of the eighteenth and nineteenth centuries was the story of Meindert Leendertsz, the God-fearing son who saved his mother from the Spanish soldiers. He was remembered with a new monument, a painting, poems for children, a theatre play and novels in the nineteenth century. ${ }^{47}$ With the rise of nationalism, civic virtues and devout self-sacrifice for the nation were elaborated in an elevated style. However, such heroes were quite rare in real life. The war on the ground was harsh, and its heroes were valiant but not very sentimental. The locals had their own tales of the revolt. Most of their heroes, like Van der Lee, De Guyon or the freebooters from Zaandam, did not yet meet the standards of romantic heroism: selfsacrifice was far from their guiding motive. On the contrary, they succeeded through cunning tricks and brute force: in order to survive they answered violence with more violence and did not hesitate to maltreat the enemy-even when the enemy consisted of the inhabitants of a neighbouring village. In a cruel war, cruelty was a legitimate weapon. Their descendants apparently admired their bravery and liked these stories. But in order to preserve them for the future, they had to be accommodated to a new and different historical context and adapted to changing needs and norms.

47 See e.g. Adriaan Eck, De nieuwe gedenksteen voor Lambert Melisz., bij gelegenheid der Bossu-feesten onthuld te Hoorn, den 14 October 1873 (Hoorn: Persijn, 1873), 324-334, 367-377; Anna Petronella Muller-Westerman, Lambert Melisz, of De ouderlievende jongeling van Westzanen. Vaderlandsch tooneelspel, in drie bedrijven (Amsterdam: Westerman en Van Hulst, 1834). 


\section{APPENDIX \\ CY SUIVANT A LA CHANSON PROMISE ET MENTIONNÉE EN L’EPISTRE DEDICATOIRE}

\section{CHANSON}

faite l'an 1566 par un paysan des environs le Pesquencour sur le sujet de la deffaite des brise Images à Marchiennes le 25 d' Aoust dudit an par le sieur de Guyon

Les huguenots sont assemblez

Pour les images ruiner

Et sans respecter le dimanche

Ils sont venus droit à Marchenne.

Ils ont abbatu les autels

En haine de l' Église saincte

Quand ce fut le Lundy matin

Ils ont trouvé des Catholiques.

Fery Guyon premier nommé

Le grand bailly de Pesguencour

Et nombre de ses Hennuyers

A l' Église a donné secours.

Ils y marcherent vaillament

Aux huguenots donnant l'allarme

Es maretz de monsieur l'abbé

Ils leurs ont là livré bataille.

En nombre de dix à douze vingt

Sont demeurez dessus la place

Et le Lundy au desieuner

Les huguenots avoient conclu

D'estre au disner à Bouvenies

Pour les images ruer jus

Mais ils n'avoient pas bien conclu

De prendre en ce lieu leur disner.

Ils estoient desgoustez de chair

On les voit pescher aux anguilles

Et le Lundy apres disner

Y revint tout nouvelles gens.

En despitant les Catholiques

Et aussi le saint sacrement

Ils n'y furent pas longuement

Pensant retourner tous ensembles. 
Car estans au gist à Brillon

Sont endormis dedans les kemmes

Les huguenots de Valenciennes

Quand ils en ont ouy le vent.

Ont envoyé poste sur poste

$S$ ' en enquestans par le pays

Quand ils ont sceu la verité

Ils en ont bien gratté leurs testes.

Les freres en Christ sont mis à mort

Jamais plus n'iront a la presche

Celui qui fit cette chanson

A bien gaigne les gris palto

Et voudrait bien gaigner sa vie

A combattre les Huguenots

Príons la Sainte Trinité

Qu'elle nous soit tousiours propice.

FIN 
CHAPTER ELEVEN

\section{LOST IN TIME AND SPACE? \\ GLOCAL MEMORYSCAPES IN THE EARLY MODERN WORLD}

Dagmar Freist

\section{Memory Transmission Reconsidered}

The transmission of memory is a prerequisite for the emergence, continuity and change of memory cultures. However, for the early modern period, the ways in which memories were passed on and how they changed in the process have not been studied systematically. There has also been a lack of scholarly differentiation between the transmission of memories over time, from generation to generation and their transmission through space, for instance as a consequence of migration and the dispersion of people, written media and objects. This is partly due to the fact that until recently memory and commemoration have been the domain of national and comparative historiography. In spite of differences in their research agendas both Maurice Halbwachs and Pierre Nora, the pioneers of memory studies, with their emphasis on sites and sociabilities, made the nation state the focal point of memory formation. ${ }^{1}$ Nora's Les lieux de memoire, in particular, has found many imitators who defined national sites of memory such as the Deutsche Erinnerungsorte, on which Hagen Schulze and Francois Etienne edited an influential volume. ${ }^{2}$

Students of early modern memory need to develop different parameters in order to address the more fragmented but nevertheless collective perceptions of belonging which constitute the focal point of early modern memory formation and memory transmission. A distinctive issue for the period $1500-1800$ is the formation of collective memories which were not grounded within the confines of the nation-state but which were

1 Maurice Halbwachs, On collective memory (Chicago: The University of Chicago Press, 1992), translated from: Les cadres sociaux de la mémoire (Paris: Presses Universitaires de France, 1952), originally published in Les Travaux de L'Année Sociologique (Paris: F. Alcan, 1925); P. Nora (ed.), Les lieux de mémoire, 7 vols. (Paris: Edition Gallimard, 1984-1992).

2 Etienne François and Hagen Schulze (eds.), Deutsche Erinnerungsorte, 3 vols. (Munich: C.H. Beck, 2001). 
generated in a dynamic between translocal developments and local circumstances. In this essay, religion will serve as a focal point of collective memory formation in the early modern period. Between the sixteenth and the eighteenth centuries, the conflicts between and within world religions, religious wars, the inquisitions and the prosecution of 'heretics', missionary programmes, religious print media and objects, rituals and dogma had a profound impact on collective memory formation across time and space.

Apart from the necessary reconsideration of what we might define as the focal points of memory formation in the early modern period, the analysis has to consider who were the agents in memory transmission. ${ }^{3}$ In this context, agency refers not only to people but also to media and material objects or 'things'. While people use objects to define and document their selves, things also enter and mark human lives. As tools of a practical nature or as keys to memory, things structure the actions and interactions of people. Things mark people's life stories, yet they also have their own biographies. This implies that we go beyond the idea of objects as 'memory containers' with a fixed meaning and also reject the notion of artefacts as 'repositories of memory', which are kept alive in memory transmission and which can be retrieved by cognitive acts of remembering these meanings and what they stand for. ${ }^{4}$ Instead, artefacts should be conceived of as co-actors of the social, in a network of references to varying meanings that are being bestowed on things by different actors in specific contexts and social practices. ${ }^{5}$ While the concept of the 'biography of things', first

${ }^{3}$ For the role of agents in transnational memory formation see Aleida Assmann and Sebastian Conrad, 'Introduction', in Aleida Assmann and Sebastian Conrad (eds.), Memory in a global age. Discourses, practices and trajectories (Basingstoke: Palgrave Macmillan, 2010), 1-16, there $2-4$.

4 Andrew Jones, Memory and material culture (Cambridge: Cambridge University Press, 2007), 42. In his essay on Global flows and local cultures, Helmuth Berking has stressed that 'place matters' for meaning and his ideas can be built upon for the relevance of social sites when looking at memory transmission as constituted in social practices. See Helmuth Berking, 'Global flows and local cultures. Über die Rekonfiguration sozialer Räume im Globalisierungsprozess', Berliner Journal für Soziologie 8 (1989), 381-392.

5 Whereas Bruno Latour proclaims the principle of symmetry between things and humans, others like Andrew Pickering admit that things help to constitute society but continue to focus on the human as the source of activities and practices. See for instance Bruno Latour, Reassembling the social. An introduction to actor-network-theory (Oxford and New York: Oxford University Press, 2005), Andrew Pickering, 'Practice and posthumanism. Social theory and a history of agency', in Theodore R. Schatzki, Karin Knorr Cetina and Eike von Savigny (eds.), The practice turn in contemporary theory (London and New York: Routledge, 2001), 163-174. See also Andrew Jones and Nicole Boivin, "The malice of 
introduced by Igor Kopytoff, emphasises the cognitive aspects behind the production of commodities, in which the object is 'culturally marked as being a certain kind of thing, ${ }^{6}$ the reconsideration of artefacts as participants in social practices addresses their relation to humans as constitutive of meaning. ${ }^{7}$ These processes of meaning-making do, of course, always depend on the specific sites of social practices. New social sites reconstitute social practices and in the process reconstitute memory formation and meaning, a process which can also be described as the re-memory of memory. In other words, 'human and non-human action is contextualised by social practices and arrangements in a specific sense'. ${ }^{8}$

Finally, we should not reduce memory to the cognitive act and/or competence of remembering, the ritual aspect of memory performance or the acknowledgement of collective memory sites. ${ }^{9}$ Instead, I want to propose a shift of analytical perspective by suggesting that memory formation and memory transmission are constituted in social practices around shared understandings which are defined as the 'skills, or tacit knowledge and presuppositions, that underpin activities' and need to be analysed as such. ${ }^{10}$ These social practices are construed as materially mediated activities, a perspective which acknowledges that 'things' help to constitute human sociability.

The aim of this essay is to map out a new analytical perspective on memory cultures and memory transmission during the transitory period

inanimate objects. Material agency', in Dan Hicks and Marie Claude Beaudry, The Oxford handbook of material culture studies (Oxford: Oxford University Studies, 2010), 333-351.

${ }^{6}$ Igor Kopytoff, 'The cultural biography of things. Commoditization as process', in Arjun Appadurai (ed.), The social life of things. Commodities in cultural perspective (Cambridge: Cambridge University Press), 64-91, there 64.

7 Andrew Jones has challenged the 'characterization of memory as an internalized cognitive function', and instead reconsidererd 'not only the wider role of human communities in the practice of remembering but also the participatory role of material culture in the process of remembering'. See Jones, Memory, 31 .

8 Michael Jonas, 'The social site approach versus the approach of discourse / practice formation', Reihe Soziologie / Sociological Series 92, 1-24, there 2. For the theoretical framework see Theodore R. Schatzki, The Site of the Social. A philosophical account of the constitution of social life and change (Pennsylvania: The Pennsylvania State University Press, 2002), esp. chpt. 3 .

9 Premodern memory studies have often focused on cognitive abilities and recall. See for instance the seminal study of Frances A. Yates, The art of memory (Chicago: University of Chicago Press 1966); A new approach has been suggested by Jones, Memory, esp. 6-13. See also Michael Rowlands, 'The role of memory in the transmission of culture', World Archaeology 25/2 (October 1993), 141-151.

10 Theodore R. Schatzki, 'Introduction. Practice theory', in Schatzki, Knorr Cetina and Von Savigny (eds.), The practice turn, 1-14, there 2. 
of early modern state formation. This requires a focus on the spatial as well as the diachronic dimension of memory. Memory transmission itself will be approached from the perspective of time with reference to generational memory and of space with reference to migration and the dispersion of people, written media and artefacts. It is here that the idea of being 'lost in time and space' comes in: 'Lost' in this context means the loss of a fixed and locally coded meaning through the de-contextualisation, reshaping and adaption of memory in the process of transmission and re-contextualisation in a new time and space. In the following I will first develop the concept of early modern 'glocal memoryscapes'. In a second step I will look at the phenomenon of memory transmission over time as memories are passed on, adapted, transfigured or suppressed from generation to generation. Thirdly, I will focus on the role of material culture for memory transmission. Here, too, my point of reference will be recent studies and theoretical approaches, which I will try to relate to early modern phenomena and sources. By way of conclusion I will argue that in processes of memory transmission and identity formation, time, space and things are intrinsically interrelated.

\section{Glocal Memoryscapes}

The emerging global turn in memory studies is a rather recent phenomenon, so far it has inspired mostly works focusing on the twentieth century. ${ }^{11}$ Among the first influential studies in this field is Daniel Levy's and Natan Sznaider's book The Holocaust and Memory in the Global Age of 2001. ${ }^{12}$ The authors analyze the Holocaust as a key to our understanding the construction of collective memory by demonstrating the competing cultural uses of the Holocaust in film, popular history, and social theories. According to their argument, memories of the Holocaust have been de-contextualised from the original event and offer a framework for interpreting contemporary acts of injustice such as ethnic cleansing and genocide. Building on this idea Aleida Assmann and Sebastian Conrad have argued in Memory in a Global Age that the nation is no longer the

11 John Sundholm, 'Visions of transnational memory', Journal of Aesthetics \& Culture 3 (2011), 1-5.

12 Daniel Levy and Natan Sznaider, Holocaust and memory in the global age (Philadelphia: Temple University Press, 2008), transl. by Assenka Oksiloff (first published as Erinnerung im globalen Kontext. Der Holocaust, Frankfurt/Main: Suhrkamp, 2001). 
'natural container of memory debates'. ${ }^{13}$ Instead, the interconnections of global frameworks and national memory discourses have to be analyzed; in other words, memory has to be studied from the angle of histoire croisée in its global entanglements. In their edited volume of collected essays on memory and migration, Julia Creet and Andreas Kitzmann point out that 'migration rather than location is the condition of memory', and they emphasise the connections between memory, place, and displacement. ${ }^{14}$

Whereas research on collective memories has recently discovered the transnational nature of memory formation in the twentieth century, this was actually also a central feature of early modern memory formation. From the fifteenth century on we can observe the formation of 'translocal memories', connecting people and places across time and space. This reconsideration of the spatial dimension of memory requires a specification of what is meant by 'space'. Here, it no longer refers to an administrative, constitutional, geographical or allegedly cultural unit but is emergent, that is, it is constituted and de-constituted through the interplay of social relations and practices, the attaching of meanings and interpretations, materiality and physical realities. Whereas the idea of space as emergent has been inspired by social theories, ${ }^{15}$ human geographers have re-defined the concept of landscape by emphasizing how inhabitation leads to the attribution of meaning and by proposing that landscape is a 'discovered subject'. ${ }^{16}$ Furthermore, the 'perceptions of and values attached to landscapes' 17 have been interpreted to 'encode values and fix memories to places that become sites of historical identity'. ${ }^{18}$ Landscape, so the argument goes, 'provides a context for the negotiation of place, memory and

13 Assmann and Conrad, 'Introduction', 6.

14 Julia Creet and Andreas Kitzmann, 'Introduction', in Julia Creet and Andreas Kitzmann (eds.), Memory and migration. Multidisciplinary approaches to memory studies (Toronto: University of Toronto Press, 2011), 9. See also Sundholm, 'Visions of transnational memory'.

15 Martina Löw, Raumsoziologie (Frankfurt am Main: Suhrkamp, 200o). For a wider discussion see the collection of essays by Jörg Döring and Tristan Thielmann (eds.), Spatial Turn. Das Raumparadigma in den Kultur- und Sozialwissenschaften (Bielefeld: Transcript, 2008).

16 Timothy Clack, 'Thinking through memoryscapes. Symbolic environmental potency on Mount Kilimanjaro, Tanzania', in T. Myllyntaus (ed.), Thinking Through the Environment. Green Approaches to Global History. (Cambridge: The White Horse Press, 2011), 115-134, there 116.

17 Ibid., 116.

18 Pamela J. Stewart and Andrew Strathern, 'Introduction', in Pamela J. Stewart and Andrew Strathern (eds.), Landscape, memory and history 83 (London, 2003), 83 and also Clack, 'Thinking', 116. 
community'. ${ }^{19}$ Translocal memories connect people and spaces, and they change in the process of transmission, so that the relevance and/or meaning of memories might have become lost in negotiations over memory in time and space. Memory and re-memory are evident in social practices and their relation to things and meanings.

Early modern re-memory was inseparably linked to both global and local memory cultures and can best be described by a concept that I should like to coin, that of the glocal memoryscape. In a variation on recent studies such as those by Kendall Philipps and Mitchell Reyes on global memoryscapes, ${ }^{20}$ the concept of glocal memoryscapes pays tribute to the interplay of local and translocal influences on memory thus 'collapsing the antinomy between the local and the global into the single, but complex, theme of the glocal'. ${ }^{21}$ The interplay of the local and the global is, first, based on networks which stretch across borders and are constituted by social relations, and secondly, it focuses 'on the spatial dimension of sociocultural life'.22 The term 'memoryscape' was originally coined by the discipline of human geography, and it implies an understanding of landscape as the product of an interrelation between culture, emotion, memory and the physical landscape. "The notion of the memoryscape is an expression of the convergence zone that homogenises these concepts'. ${ }^{23}$

How, then, can memory construction and memory transmission work in an early modern global setting? A prerequisite for 'memoryscapes' are global communication spaces in the form of social and cultural networks which bind people together across borders as well as a translocal perception of space as 'spatially projected reachability'. ${ }^{24}$ As an inhabited landscape, this space provides the platform for the negotiation, production and transmission of collective meanings of the past. Furthermore,

19 Clack, 'Thinking', 116. This refers to landscapes as lived and experienced space, filled with materiality and the meanings attributed to it by humans.

20 Kendall R. Phillips and G. Mitchell Reyes (eds.), Global memoryscapes. Contesting remembrance in a transnational age (Alabama: University of Alabama Press, 2011).

21 The concept of glocalization implies that the global is expressed in the local and the local is the particularization of the global. Roland Robertson, "The conceptual promise of glocalization. Commonality and diversity', consulted on 10 December 2012; and R. Robertson, 'Glocalization: time-space and homogeneity-heterogeneity,' in Mike Featherstone, Scott Lash and Roland Robertson (eds.), Global modernities (London: Sage, 1995), 25-44.

${ }^{22}$ Robertson, 'Conceptual promise'.

23 Clack, 'Thinking' 115: 'The memoryscape is a refinement of the conceptual maps of meaning promoted in the discipline of human geography.'

24 Translation by the author. Gerhard Hard, 'Der Spatial Turn, von der Geographie her beobachtet', in Döring and Thielmann (eds.), Spatial Turn, 263-315; there 292-293. 
according to Assmann, there have to be 'memory activists' and 'transnational memory alliances' at work, playing an active role in the construction of global memories and the transmission of memories in a global world. 25

The most elaborate glocal memoryscapes in the early modern period were those of diasporas. The term diaspora describes both the dispersion of people from their original homeland over different parts of the world and the community formed by such a people within their new place of residence, as well as across borders through family and religious networks. Whereas earlier research equaled diasporas with victims, more recent studies, first introduced by the sociologist Robin Cohen, also include those migrants into the concept of diaspora, who voluntarily left their homeland and maintained or formed a strong religious, cultural and/or religious identity abroad. ${ }^{26}$ A central feature of these diasporic communities were their close-knit networks, which extended across borders and also tied people together in a new environment based on family ties, ethnicity, religion, myths of origin and sociability, and - evolving from this - on trust and mutual dependence. ${ }^{27}$ The links were kept alive both through actual people on the move and, virtually, through correspondence and media which reiterated as well as constructed the sense of a closed community of shared and exclusive values and belief systems. A further characteristic of these diasporas was the awareness of 'belonging' to this group of people, the creation of an inner structure through things like poor relief, education, value systems, church formation, loan systems and trust, and loyalty towards one's own translocal group, as well as the construction of memory and narrative structures about belonging and identity.

In diasporas which were defined mainly by religion, it was obviously the clergy who served as important 'memory activists' by forming 'transnational memory alliances' through carefully designed correspondence networks in the production and circulation of newsletters. These networks

25 Assmann and Conrad, 'Introduction', 4, 9.

26 Robin Cohen, Global diasporas. An introduction (London: UCL Press and Seattle: University of Washington Press, 1997).

27 See Dagmar Freist, 'Uneasy trust relations, transcultural encounters and social change — diasporas in early modern Europe', in Sebastian Jobs and Gesa Mackenthun (eds.), Agents of transculturation. Border-crossers, mediators, go-betweens (Münster: Waxmann, 2013). Also Susanne Lachenicht and Kirsten Heinsohn (eds.), Diaspora identities. Exile, nationalism and cosmopolitanism in past and present (Frankfurt am Main: Campus Verlag, 2009) and Dagmar Freist and Susanne Lachenicht (eds.), Diasporas as translocal societies in the early modern period (forthcoming). 
aided in the construction of memories of a common root, nation and homeland (a constructed landscape independent of any real space), virtues, beliefs and practices. ${ }^{28} \mathrm{~A}$ case in point is the Protestant mission, the 'Danish-Halle Mission' which was founded in India in 1706 and which notwithstanding the worldwide dispersion of its members was based on a densely knit and highly controlled network and the permanent construction of belonging. All reports, diaries and letters sent from the various mission posts to the directors of the pietists who had their centre in the Saxon city of Halle (Germany) were censored and published as the first Protestant missionary journal, the Hallesche Berichte. ${ }^{29}$ These newsletters were introduced by prefaces which repeated and instilled religious identity through collective memories and were thus part of the pietist communication culture in a glocal sense of the word. ${ }^{30}$ Global communication spaces and the construction of a mutually inhabited religious landscape informed networks as their social and spatial reach developed through reports and letters sent in by members of the mission worldwide. Through their narratives they tried to establish their religious identity and values as separate from those of the 'heathen' world in which they worked and to reaffirm their belonging to a community of shared religious thoughts and deeds. These reports were censored in order to preserve a unified ideal of a pious life, religious practices and habitus based on the ideals of the Halle pietists.

A central question for further research will be to what extent these memories were gradually influenced and transformed by experiences of religious life in a diaspora in different parts of the world and through the encounter with other religious groups and cultures. We should also like to know how these experiences altered and complicated the construction of jointly inhabited landscapes of belonging. Correspondence with

${ }^{28}$ For a recent study on correspondence networks see for instance Gisela Mettele, Weltbürgertum oder Gottesreich. Die Herrnhuter Brüdergemeinde als globale Gemeinschaft 1727-1857 (Göttingen: Vandenhoeck \& Ruprecht, 2009).

29 'Der Königl. Dänischen Missionarien aus Ost-Indien eingesandter Ausführlichen Berichten, Von dem Werck ihres Amts unter den Heyden, angerichteten Schulen und Gemeinen, ereigneten Hindernissen und schweren Umständen; Beschaffenheit des Malabarischen Heydenthums, gepflogenen brieflichen Correspondentz und mündlichen Unterredungen mit selbigen Heyden ... Teil 1-9 (Continuation 1-108)', Halle, in Verlegung des Waysen-Hauses, 1710-1772 (Digital library http://192.124.243.55/digbib/hb.htm). For an English version of the digital library see http://192.124.243.55/cgi-bin/dhmeng.pl.

30 Cornelia Jaeger, Kontinuitäten und Diskontinuitäten in den Halleschen Berichten, unpublished master thesis, Oldenburg 2011; Ulrike Gleixner, Pietismus und Bürgertum. Eine historische Anthropologie der Frömmigkeit (Göttingen: Vandenhoeck \& Ruprecht, 2005). 
parties beyond these official newsletters casts a new light on these social networks and the emergence of social sites, as well as on social practices that are influenced by officially constructed memories and the interplay of global and local factors of memory transmission. ${ }^{31}$ Of special interest in this correspondence is the constitution of networks and forms of belonging which go beyond the officially defined diaspora and its ideals. Furthermore, the exchange of artefacts across the globe played a central role in these letters, as a vital part of social practice, memory transmission and the reconstitution of social sites.

Another form of glocal memoryscapes in the early modern period which has so far received little attention as a transnational/translocal phenomenon was the transmission of memories of martyrdom, defined as the commemoration of heroic deaths for religious reasons. Whereas these martyrologies could serve on the one hand as the basis of a national collective memory and help forge the nation state, as did John Foxe's Book of Martyrs ${ }^{32}$ in England, they also created a transnational awareness of belonging, because of the transmission of memories of suffering for religious reasons among co-believers across borders. ${ }^{33}$ 'Transnational alliances' of 'memory activists' were formed through the visualisation of martyrdom, the transmission and translation of the life stories of martyrs and finally through the de-contextualisation of martyrdom and the construction of 'martyrdom' as the epitome of religious steadfastness even in the face of persecution and death. Transnational alliances were evoked through the generalisation of suffering with religious brethren and sisters wherever they were oppressed. Memory transmission of both religious sufferings and belonging worked through the continuous reiteration of martyrdom and its material reproductions in the form of pictures and books from generation to generation, as we know from the study of inventories, testaments, woodcuts and art.

A final example of the de-contextualisation of events and memory culture and the subsequent narrative and material construction of glocal memoryscapes in the early modern period is the so-called leyenda negra, the Black Legend. The term is used to describe the complex of negative

31 See Dagmar Freist, 'Letters from Paramaribo. The Herrnhuter diaspora in the eyes of Catharina Borck', in Dagmar Freist and Susanne Lachenicht (eds.), Diasporas as translocal societies in the early modern period (forthcoming).

32 The Unabridged Acts and Monuments Online or TAMO (HRI Online Publications, Sheffield, 2011). Available from: http://www.johnfoxe.org (consulted on 30 December 2012).

33 Brad S. Gregory, Salvation at stake. Christian martyrdom in early modern Europe (Harvard: Harvard University Press, 2001). 
imagery of Spain and Spaniards that was created in numerous pamphlets, woodcuts, works of art and treatises from the sixteenth century onwards. ${ }^{34}$ The negative image was based on negative portrayals of the Spaniards which can be traced back to the thirteenth century and the work of the Spanish Inquisition but especially to the accusations which vilified the Spanish as a corrupt and cruel people who subjugated and exploited the New World Indians, stole their gold and silver, infected them with disease, and killed them in numbers without precedent. ${ }^{35}$ Bartolomé de las Casas' Brevísima relación de la destrucción de las Indias of 1552, which offered a critique of the behaviour of the Spanish conquistadores of the Americas, has often been described as the first published book to contribute to the Black Legend. This work was appropriated by groups and nations who opposed the Spanish Empire such as the Protestant Walloons, the French Huguenots, groups in Venice, and especially the rising powers of England and the Netherlands. In these reproductions and subsequent adaptations to other political contexts the 'Black Legend' was de-contextualised and emerged as an epitome of the cruelty exercised by the Spanish in general. A striking example is the anti-Spanish propaganda with which Netherlandish rebels attacked their Habsburg overlords during the Dutch Revolt in the sixteenth century, when the 'Black Legend' was re-membered and blended with memories of the cruelties committed by the Spanish in the Netherlands. In 1580, William I, Prince of Orange (1533-1584), who led the Dutch in their rebellion against Spanish Habsburg rule, declared that Spain 'committed such horrible excesses that all the barbarities, cruelties and tyrannies ever perpetrated before are only games in comparison to what happened to the poor Indians. ${ }^{36}$ The de-contextualisation of the 'Black Legend' from colonial Spain and its re-contextualisation in the Dutch Revolt in the process of memory transmission had as its objective

34 Friedrich Edelmayer, "The "leyenda negra" and the circulation of anti-catholic and anti-spanish prejudices' in European History Online (EGO), published by the Institute of European History (IEG), Mainz 2011-06-29, http://www.ieg-ego.eu/en/threads/modelsand-stereotypes/the-spanish-century/friedrich-edelmayer-the-leyenda-negra-and-thecirculation-of-anti-catholic-and-anti-spanish-prejudices, consulted on 15 February 2013.

35 For a critical reappraisal of the legend see B. Keen, "The Black Legend revisited. Assumptions and realities', The Hispanic American Historical Review 49 (1969), 703-719; and recently Margret Rich Greer, Maureen Quilligan and Walter D. Mignolo (eds.), Rereading the Black Legend. The discourses of religious and racial difference in the renaissance empires (Chicago: University of Chicago Press, 2008).

36 David Brion Davis and Steven Mintz (eds.), The boisterous sea of liberty. A documentary history of America from discovery through the civil war (Oxford: Oxford University Press, 2000), 39 . 
to legitimise the political breach with the Spanish Habsburg overlords. ${ }^{37}$ The term was coined in the nineteenth century by the Spanish historian Julián Juderías in his book La Leyenda Negra which was first published in $1914{ }^{38}$ It inspired a historiographical debate about how to analyse colonial history and created in response a 'white legend'. ${ }^{39}$ It also played a role during the Spanish Civil War and is reflected to this day in American attitudes towards Spanish migrants. ${ }^{40}$

\section{Memory Transmission over Time}

While memory transmission through space involves a complex process of decontextualisation, loss of meaning, adaptions and recontextualisations, the same can be said about the transmission of memories over time. To illustrate this, I will start from the micro-perspective of memory transmission within the family from generation to generation. In the course of the European Reformation many families were divided along religious and confessional lines, which influenced the practice and materiality of memory transmission within families and across generations. Generational studies have until recently focused on generation as an explanatory category in the process of periodisation or in understanding social dynamics. Alex Walsham, for instance, has shown how 'the notion of generational strife was invoked at various stages of England's long Reformation'. ${ }^{41}$ Other recent work has approached 'generation as a category of memory'

37 See Dagmar Freist, “The 'Dutch Century', in European History Online (EGO), published by the Institute of European History (IEG), Mainz 2012-10-17, http://www.ieg-ego.eu/en/ threads/models-and-stereotypes/the-dutch-century, consulted on 15 February 2013); Judith Pollmann, 'Eine natürliche Feindschaft. Ursprung und Funktion der Schwarzen Legende über Spanien in den Niederlanden 1560-1581', in Franz Bosbach (ed.), Feindbilder. Die Darstellung des Gegners in der politischen Publizistik des Mittelalters und der Neuzeit (Bayreuther Historische Kolloquien 6) (Cologne: Böhlau Verlag, 1992), 73-93, there 92.

38 Maria DeGuzman, Spain's long shadow. The Black Legend, off-whiteness, and AngloAmerican empire (Minneapolis, University of Minnesota Press, 2005).

39 For instance Benjamin Keen, 'The white legend revisited. A reply to Professor Hanke's "Modest proposal"', Hispanic American Historical Review 51 (1971), 336-355 and more recently with a critical review of the controversy A.L. Walsh, Arturo Pérez-Reverte. Narrative tricks and narrative strategies (London: Tamesis Books, 2007), 117.

40 DeGuzman, Spain's long shadow.

41 Quote from abstract of Alexandra Walsham, 'The Reformation of the generations. Youth, age and religious change in England, c. 1500-1700', Transactions of the Royal Historical Society, 6th Series, 21 (2011), 93-121. 
based on the understanding of memory as 'collective and social'. ${ }^{42}$ In this perspective memory is constructed rather than reconstructed through social interaction and communicative processes within the parameters of specific social milieus and their memory discourses. Generations define themselves, or are being perceived, as collective agents of these memory discourses and their inherent practices. Memory transmission as a form of bonding is constituted in social practices imbued with implicit understandings of a collective memory and its materiality, which connect various landscapes, nature and the lived environment.

Central to all empirical studies and theories on generation is the question of the degree of universality of 'generational phenomena' and of how we grasp a generation analytically. Leopold von Ranke, one of the first scholars to deal with generation as an analytical category, defined a historical generation as a 'row of shining figures who themselves are closely related and in whose antithesis the development of the world continues to progress' ${ }^{43}$ In a pioneering way, the historian and social scientist Karl Mannheim tried to capture the historical significance of generation by introducing the category of 'experience' and of 'understanding of the world' in young age through the exposure to specific environments which shape the mind for later perceptions and experiences of the world. He argues that 'we will only talk about generational context when real social and intellectual contents create a link between individuals in the same generational stratum' and adds that 'those groups who, within the same generational context, experience events in different ways, form in each case different generational units'. ${ }^{44}$ Present research acknowledges the diversity within generations rather than seeking for generational universals. Nevertheless, there remains analytical value in the idea that certain generational groups have been exposed to specific contexts and milieus in the course of their lives, which shape their ways of understanding and relating to the world. In this sense, generation as a memory category in the context of the reformation is worth further research. How were the Reformation and the religious developments of this period of unprecedented upheaval later remembered by those who experienced them? What was the manner in which such memories evolved over time?

\footnotetext{
42 Ulrike Jureit, Generationenforschung (Göttingen: Vandenhoeck \& Ruprecht, 2006), 114-115 (translation by the author).

43 Ibid., 274 (translation by the author).

44 Ibid., 278.
} 
Memory transmission within early modern families could follow various trajectories. Especially in Protestant contexts autobiographical writings served as a tool for memory transmission to create a religious identity and a specific habitus from one generation to another. Such autobiographical texts were often addressed directly to the next generation in order to instill them with the wisdom and experience of their elders. The German historian Ulrike Gleixner has analysed numerous autobiographies and other writings by pietists and has shown how the practice and the narrative construction of pietism, as it was passed down from generation to generation, produced its own religious culture and habitus, and bonded each new generation through the transmission of memory and identity building as a specific religious and social group. ${ }^{45}$ Besides the written media for memory transmission and identity building within the family, there was also the material world of religious beliefs. Here we can count family portraits endowed with religious signifiers, church pews, public donations, graveyards and gravestones, as well as the domestic material culture of religious practices which was passed down from generation to generation. However, we do not yet have any systematic study of how specific groups of one generation related to the Reformation and the emergence of religious multiconfessionalism and how these differing experiences influenced memory transmission and the building of religious and family identities. 46

Correspondence among family members as well as autobiographies provides ample evidence of the strain put on families after the conversion of some of their members and the subsequent division of family bonds along religious lines. Depending on the scope of ensuing conflicts and emotions, such acts of conversion could enter the family memory as traumatic experiences and be used to keep other members in line. The same was true for mixed marriages which always implied the danger of conversion or at least of the bringing up of future children in the 'wrong' religion. ${ }^{47}$

An interesting case in point is the dynamic between migration, material culture and memory transmission within families in religious minorities such as, for instance, Catholics in England or Protestants in Austria who

\footnotetext{
45 Gleixner, Pietismus und Bürgertum, 349.

46 For a first conceptual approach see Walsham, 'Reformation and Generation'.

47 Dagmar Freist, Glaube-Liebe-Zwietracht. Konfessionellgemischte Ehen in Deutschland in der Frühen Neuzeit (Munich: Oldenbourg, forthcoming 2014).
} 
were not allowed to practice their faith in public. ${ }^{48}$ These religious minorities were able to lead a religious life because they 'experimented with a variety of new alternatives for worship, religious identity, and communal religious experience' and 'viewed their actions as negotiating between Catholic orthodoxy and practical necessity'. ${ }^{49}$ These religious practices had to be passed down from generation to generation and were linked to artefacts. If we take the materiality of religious practices seriously, we have to reconsider the restrictions on the use of religious objects and what this meant in everyday religious practices, to find out how such restrictions shaped experiences and eventually the transmission of memory. In a fascinating study, Richard Williams has shown the various uses to which playing cards were put as material mediators of Catholic religious practices among prisoners in the Tower of London in seventeenth-century England. ${ }^{50}$ Whereas for some these playing cards were simply a game, Catholics could employ them as objects of devotion, even fold them into small altars, thus recalling forms of devotion in social practices and instilling these artefacts with specific meanings.

For Protestants, both the instructions of parents and books were vital for the survival of their faith as a minority. Protestant books were not permitted in Catholic Austria, and Protestants who tried to practice their faith privately and in secret had to invent ways of hiding and recovering the materials they needed for their religious practices. ${ }^{51}$ We still have traces of these practices in the shape of book hiding places under chimneys, above doors, under floorboards or below the ceiling. ${ }^{52}$ Whereas later

48 Alexandra Walsham, "Yielding to the extremity of time". Conformity, orthodoxy, and the post-Reformation English Catholic community', in Peter Lake and Michael Questier (eds.), Conformity and orthodoxy in the English church, ca. 1560-1660 (Woodbridge 2000), 211-236; Rudolf Leeb, Martin Scheutz and Dietmar Weikl (eds.), Geheimprotestantismus und evangelische Kirchen in der Habsburgermonarchie und im Erzstift Salzburg (17./ 18. Jahrhundert) (Vienna and Munich: Böhlau, 2009).

49 Lisa McClain, Lest we be damned. Practical innovation and lived experience among Catholics in Protestant England, 1559-1642 (New York and London: Routledge, 2004), 4.

50 Richard L. Williams, 'Forbidden sacred spaces in Reformation England', in Andrew Spicer and Sarah Hamilton (eds.), Defining the holy. Sacred Space in Medieval And Early Modern Europe (Aldershot and Burlington, VT.: Ashgate, 2005), 95-115. I thank Kerstin von der Lieth for pointing this book out to me.

51 Gustav Reingrabner, 'Einige Bemerkungen zu Frömmigkeit und Glaube der österreichischen Geheimprotestanten', Österreichische Gesellschaft zurErforschung des 18. Jahrhunderts. Das achtzehnte Jahrhundert und Österreich, Jahrbuch der Österreichischen Gesellschaft (1994), 35-55.

52 Dietmar Weikl, 'Das Buch im Geheimprotestantismus', in Johannes Frimmel and Michael Wögerbauer (eds.), Kommunikation und Information im 18. Jahrhundert. Das Beispiel der Habsburgermonarchie, Buchforschung 5 (Wiesbaden, Harrasowitz, 2005), 
generations might come across these 'gaps' in houses without recognising their past functions, family ties and generational links served as vital networks to provide the material culture needed in order to maintain religious practices in a diasporic situation. ${ }^{53}$ Thus, 'religious things' in the domestic culture of diasporas usually carried traces of other places and countries and so bore witness of religious oppression, identity and belonging; in other words, they connected to other landscapes. At the same time, passing down such 'forbidden' religious things served to transmit memories of one's coreligionists' brave and pious survival in a hostile environment. Over time such objects could become tokens of piety, symbols of the struggle for religious freedom, or simply reminders of heroism and civil courage.

\section{Material Culture and Memory Transmission}

The role of materiality in the spatial (i.e. migration) and generational dimensions of memory transmission is important in 'figuring diasporic positioning and identity politics' but also in other forms of identity formation. ${ }^{54}$ In a way material culture is a stimulus for a re-memory of memories which is part of the process of retrieving and reconceptualising memories in a new time and space.

The role of things in memory transmission always depends on the specific usages inherent in their materiality and the meaning which is attributed to them. ${ }^{55}$ As is the practice today, early modern social actors were expected to know implicitly the correct usage of a thing based on its materiality, meaning and context. If they lost the implicit knowledge and skill of how to use it and to what end, the item lost its relevance in social practices and was simply no longer intelligible. It might, however, as in the

255-263; and Dietmar Weikl, 'Das religiöse Leben im Geheimprotestantismus in den habsburgischen Erblanden und im Erzstift Salzburg', in Leeb, Scheutz and Weikl (eds.), Geheimprotestantismus, 457-474.

53 Giorgio Riello, 'Things that shape history. Material culture and historical narratives', in Karen Harvey (ed.), History and material culture. A student's guide to approaching alternative sources (New York: Routledge, 2009), 24-46, there 26-32.

54 Divya P. Tolia-Kelly, 'Locating processes of identification. Studying the precipitates of re-memory through artefacts in the British Asian home', Transactions of the Institute of British Geographers 29/3 (2004), 314-329, there 314.

55 For the relational understanding of meaning, competence and practices see Elizabeth Shove, Mika Pantzar and Matt Watson (eds.), The dynamics of social practice. Everyday life and how it changes (London: Sage, 2012). 
case of religious objects, still carry its mnemonic function-for instance that of being or of having been a relic. ${ }^{56}$ The meaning of a specific thing may shift from the useful to the forgotten object, from rubbish to a (rediscovered) collector's or cult object, or even to materialised memory in a museum or in the collective memory. ${ }^{57}$

As David Morgan and others have argued, religious belief is rooted in and sustained by material practice. ${ }^{58}$ In a recent study Carolyn Walker Bynum has shown that in the period between $115^{0}$ and 1550, an increasing number of Christians in Western Europe made pilgrimages to places where material objects - among them paintings, statues, relics, pieces of wood, earth, stones, and Eucharistic wafers - allegedly sprang into life through such activities as bleeding, weeping, and walking. ${ }^{59}$ By the fifteenth century such phenomena were at the heart of religious practice and polemic, and they became highly contested once some began to promote a turn to inward piety which rejected material objects of devotion. Consequently, the animation of images and the hostility to them on the part of iconoclasts constituted a parallel phenomenon in the course of religious fragmentation of Europe. Material culture and religious practices represented religious beliefs, and the transmission of things marked both religious belonging and its commemoration.

Students of the Reformation and religious pluralism have only gradually discovered the relevance of material culture both for the understanding of religious practices and for processes of religious subjectivisation or self-fashioning. Among the most important arguments in the present debate about relics and Protestantism is the claim that the material practices of Protestants must no longer be read as 'deviations from orthodoxy that bear witness to subconscious popular resistance to the reformation' but instead they have to be 'interpreted [...] as authentically Protestant phenomena'. ${ }^{60}$ Whereas studies on Catholicism have long emphasised the materiality of religious practices especially with reference to processions,

\footnotetext{
56 See Stefan Laube, Von der Reliquie zum Ding. Heiliger Ort-Wunderkammer-Museum (Berlin: Akademie Verlag 2011), 199-264.

57 For a discussion of material culture approaches see 'AHR conversations. Historians and the study of material culture', American Historical Review 2009, 1355-1404.

58 David Morgan (ed.), Religion and material culture. The matter of belief (London: Routledge, 2009). See also the journal Material Religion. The Journal of Objects, Art and Belief published since 2005 by Berg journals.

59 Caroline Walker Bynum, Christian materiality. An essay on late medieval Europe (New York: Zone Books, 2011).

60 Alexandra Walsham, 'Introduction', in Alexandra Walsham (ed.), Relics and remains (Past and Present Supplement 5 (Oxford: Oxford University Press, 2010), 1-36, there 23. See
} 
pilgrimages and relics, new research on the material culture of Protestantism has focused on relics, the transformation of relics into things and the importance of a 'cult of things' for religious practices and 'the ways in which Protestantism engendered its own forms of material culture'. ${ }^{61}$ Similarly, the relevance of material culture for memory transmission is only now being addressed in religious studies. An interesting example is the famous St. Elizabeth glass, whose 'biography' or 'career steps' have been recently reinterpreted by Stefan Laube. ${ }^{62}$ Probably having come to Europe during one of the crusades, the glass came into the possession of a small Franciscan order near the Wartburg in the fourteenth century. About 1470 it travelled to the Weimar count, the Wettiner Wilhelm III. and his wife Katharina von Brandenstein, who were advanced in age but childless. In its new life, the glass was attributed with the power to bring about fertility, and it circulated as such among noble relatives of the couple. In the sixteenth century the glass regained its status as a holy relic and became part of the famous Wittenberg collection of relics, the traditional start for any public viewing of the relic chamber of Fredrick the Wise. By 1541 Martin Luther was recorded as the owner of the Elizabeth glass, and he seems to have used it in company during meals. A close friend noted: 'He reached across the table for a glass which was supposed to be the St. Elizabeth glass, filled it for himself and passed it around the table'. ${ }^{63}$

This quote is of interest for several reasons. It both refers to a glass as any vessel which was being used for drinking, and at the same time it evoked the memory of its sacred past by naming it 'the St. Elizabeth glass', which might have even been meant as a provocation. In spite of the evocation of this memory, its former sacred significance was lost in the process of memory transmission from one religious context to another. In other words, 'the Reformation involved a redefinition of the relic as a symbolic memento rather than as a miraculous divine entity' ${ }^{64}$ After 1541 we lose track of the glass' 'biography'; it entered its 'rubbish phase' until in 1910 it was rediscovered in Coburg. There it was acknowledged as a rare collector's item and its museum phase began. Given the current interest

also Ulinka Rublack, 'Grapho-relics. Lutheranism and the materialization of the world', in ibid., 144-166.

${ }^{61}$ Walker Bynum, Christian materiality; Laube, Von der Reliquie, 3-20; Walsham, 'Introduction', 23 .

${ }^{62}$ Laube, Von der Reliquie, 200-202. All references to the St. Elizabeth glass are based on these pages. Translations by the author.

${ }^{63}$ Laube, Von der Reliquie, 201.

64 Walsham, 'Introduction', 22. 


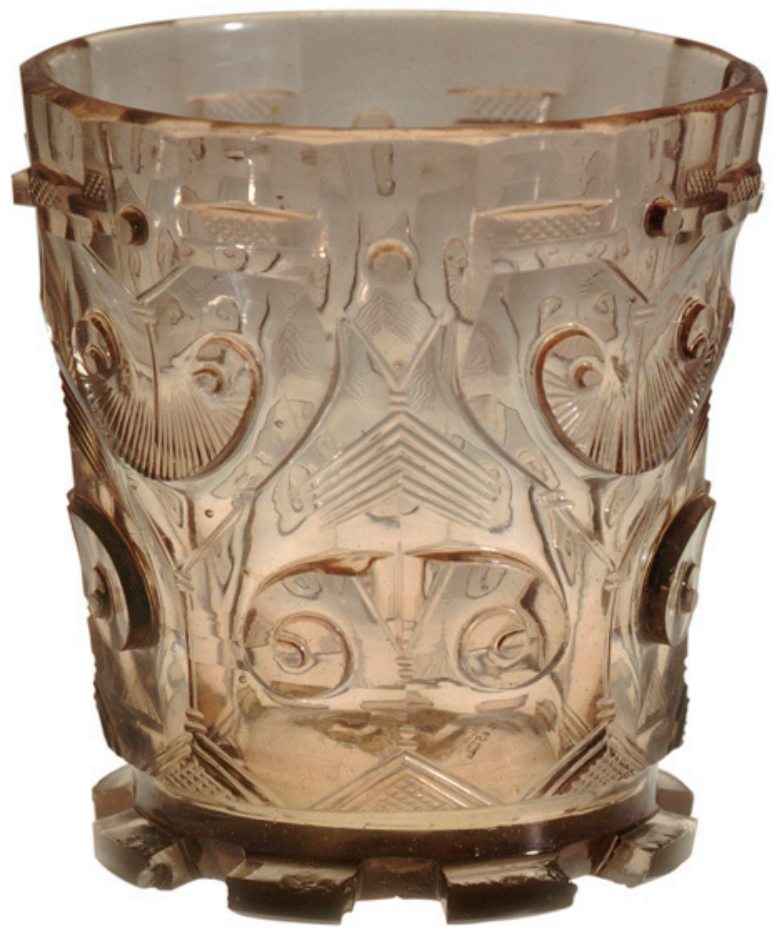

Fig. 11. St. Elizabeth glass or Hedwigsglas in possession of Martin Luther, 12th century[?], Art collection of the Veste Coburg, www.kunstsammlungen-coburg.de.

of historians in material culture the Elizabeth glass has now entered historical discourse. The glass has changed hands many times, and in the process it has been attributed with various healing and magical powers. It also served representative functions at court and, once stripped of its magical powers which soon were forgotten, it was used as a normal glass for drinking. Only in the course of becoming a collector's item and entering academic discourse was the lost memory of its former meanings reestablished and the material survival of the glass reinvested with magical power and historical significance as the 'St. Elizabeth glass'.

\section{Conclusion}

Lost in time and space: Migration, material culture, generation and memory have often been studied as isolated topics. However, a dynamic 
approach to the interplay of these phenomena opens up new ways of understanding the narrative, visual and material construction of glocal memoryscapes in the early modern period, as well as the spatial and generational dimensions of memory transmission. Whereas collective global memories have been analysed by historians of the twentieth century by focusing on 'memory activists', I have suggested a different analytical perspective by looking at how memory is constituted in social practices around shared practical understandings in specific situations and social sites. These social practices are construed as materially mediated activities, a perspective which acknowledges that objects also help to shape human sociability.

By using the experience of religious difference as a focal point of transnational memory formation in the early modern period, its materiality across time and space can serve as the material record of connections to other landscapes, natures and lived environments. The agents of memory transmission in the early modern period were people, written media and artefacts. Rejecting a merely cognitive understanding of memory, it has been argued that the meaning of memory was constituted in social practices at a specific time, situation and spatial location. 
Erika Kuijpers, Judith Pollmann, Johannes Müller, and Jasper van der Steen - 978-90-04-26125-9 Downloaded from Brill.com04/26/2023 11:57:20AM via free access 
CHAPTER TWELVE

\title{
THE SPACES OF MEMORY AND THEIR TRANSMEDIATIONS. ON THE LIVES OF EXOTIC IMAGES AND THEIR MATERIAL EVOCATIONS
}

\author{
Benjamin Schmidt
}

\section{Introduction. The Spaces of Memories}

In Greek mythology, the Titaness Mnemosyne-who personified memory and bequeathed to us the word mnemonic - is associated mostly with language and words and with the muses, including history (Clio) and poetry (Calliope). She is also a goddess of time, which reflects an association of memory and temporality. Yet the ars memoriae (art of memory) of the Ancients, inherited with great enthusiasm by Renaissance practitioners, links memory to the additional qualities of space and visuality: memory could also be pictorial and topographic (as well as textual). The Jesuit missionary Matteo Ricci famously invoked a sense of space and of the visual to convey and solidify his memory of European and Christian learning, which he carried with him to the East in the late sixteenth century (as a 'memory palace'). Ricci's mode of memory was distinctly and vividly graphic and-by dint of his exotic travels—even geographic. ${ }^{1}$

In contemplating the qualities of early modern memory, it is helpful to recall the importance of space as well as time-the 'landscape' of memory, as it has been characterised in other contexts ${ }^{2}$ - and how a sense of where we are (or have been) can shape processes of recollection and memorialisation. For if memory tends to be affiliated instinctively with time- history and our sense of the past - it plays an important role, too, in the perception of space-geography and our sense of place. The first category - time - resonates in all manner of personal, historical, and political registers, of course. Meanwhile, the second-space-allows us

\footnotetext{
${ }^{1}$ Jonathan D. Spence, The memory palace of Matteo Ricci (New York: Penguin Books, 1985).

2 Simon Schama, Landscape and memory (New York: Vintage Books, 1996); Sabine Marschall, Landscape of memory. Commemorative monuments, memorials and public statuary in post-apartheid South Africa (Leiden: Brill, 2009).
} 
not only to situate our memories (as Ricci did) in concrete spaces; but also to project onto spaces and landscapes memories that likewise incorporate personal, political, and social identities, not to mention national and imperial sensibilities. The significance of space to the project of remembering is justly underscored by Benedict Anderson in his history of collective identity and national memory, Imagined Communities. In the revised edition of that canonical book, Anderson includes a chapter on maps and geography to make the basic point that the memorialisation and articulation of space plays a vital role in the construction of 'imagined communities'. Memory expresses itself, Anderson properly points out, in geography no less than history. Mnemosyne's nine muses, that is to say, might have been augmented. ${ }^{3}$

Space is critical to an understanding of early modern memory in more ways than one. There were, to be sure, many landscapes of memory and many means of memorialising through space-in early modern Europe no less than in other moments and places in history. But early modern Europe also witnessed the dramatic augmentation of its spaces by dint of its global expansions and its flourishing interest in overseas worlds. Ricci was but one of many who described and memorialised his experiences abroad, and the field of geography thrived in these years. More generally, not only did the field of geography prosper, but so did the spaces and forms used to convey geography: the sites and sources, the methods and media, enlisted to transmit images and memories of the world. Early modern Europe was positively awash in geography; geo-memories (to coin a term) circulated in a dizzying variety of forms, recording Europe's sense of space and place in an expanding world. These sources included the putatively personal form of travel accounts as well as the less personal yet phenomenally popular genre of 'descriptions' of foreign lands; printed maps both terrestrial and maritime, along with cityscapes and numerous other manner of vedute; paintings of foreign landscapes and ethnographic subjects; exotic natural specimens and the myriad other objects collected for early modern cabinets of curiosities; and a wide range of material (socalled decorative) arts, which were embellished with exotic motifs and implicitly designed to covey to early modern consumers a sense of the world. Or better, senses of the world, since early modern geography served

3 Benedict Anderson, Imagined communities. Reflections on the origin and spread of nationalism (2nd ed., London: Verso, 1991). The key chapter, added by Anderson to his revised edition, is titled 'Census, Map, Museum', with the cartographic element especially pointing toward the visual. 
not only to introduce European audiences to the world, yet also to shape the several meanings of their world. In its many forms, geography served as an important conduit of global meaning and global memories. Images of the world and conceptions of the world passed through myriad sources and media, thereby furnishing a much valued - if also much handledform of memory. Geography, not unlike its global informants, travelled vigorously.

Early modern geography in this way imparted instructive forms of meaning and 'memory'. Sources of geography might document the personal experience of this or that traveller or artist, merchant or colonial agent overseas. Yet they do this more often than not in ways that move beyond an individual source and-in their wider iterations and circulations - in ways that register larger political and religious engagement with the world. Early modern geography, furthermore, expressly memorialised overseas sites and events - this applies for variants of modern and medieval geography, too, of course-and this memory function can be a central aspect of these sources. Richard Hakluyt offered his Principal navigations, voyages, traffiques and discoveries of the English nation (as his celebrated collection of geography narratives was titled) 'to preserve certaine memorable exploits of late yeeres by our English nation achieved.'; and this assemblage of memories came to be known as 'the Prose Epic of the modern English nation', the very foundation of imperial Britannia. ${ }^{4}$ The conceit of overseas exploits as 'memorable' - the memorialisation of exotic geography-becomes a veritable commonplace in the growing body of materials produced over the seventeenth century, especially in the most intense moment of manufacture in the century's final decades. ${ }^{5}$ Johan Nieuhof (or more likely his publisher, Jacob van Meurs) presented his readers with a 'memorable sea and land journey' (gedenkwaerdige zee en lantreize), which would go on to become one of the most popular works of geography from this period (in this case, on China). And the prolific, stay-at-home geographer Olfert Dapper typically invoked the 'memorable' accounts he described in his numerous printed geographies of the world: the 'memorable occurrences' (gedenkwaerdige geschiedenissen) of

4 Richard Hakluyt, The principal navigations, voiages, traffiques and discoueries of the English Nation (London: Christopher Barker, 1589-160o). See also Anthony Froude, 'England's forgotten worthies', in Short studies on great subjects, 4 vols. (new ed., London: Longmans, Green, 1886-88), vol. 1, 446-447.

5 This moment of geography is explored in greater detail in Benjamin Schmidt, Inventing exoticism. Geography, globalism, and Europe's early modern world (Philadelphia: University of Pennsylvania Press, forthcoming 2014). 
the Ottoman empire; the 'memorable affairs' (gedenckwaerdig bedryf) of Qing China, and so on. ${ }^{6}$

There are two things to emphasise about these self-advertised memories. First, they are not bona fide memories in the simple sense that printed volumes by the likes of Dapper-a veelschrijver, or hack writer, who churned out a steady flow of books for his profit-minded publisherdid not offer a personal memory so much as the semblance of a memory, descriptions whose origins rested in actual fact with other travellers whose manuscripts had fallen into the hands of the publisher. These were, in short, manufactured memories. Second, memories in volumes of geography were delivered not simply as narrative recollections, but also-and also more prominently - as pictorial representations. For these textual allusions to processes of memorialisation belie the basic fact that geography in this period, especially in the form produced so richly and abundantly in the hub of geography that was the Netherlands, was a pronouncedly visual medium. In the second half of the seventeenth century, Dutch ateliers specialised in a brand of large, lavishly illustrated, emphatically graphic books, which were ambitiously translated and exported to the rest of Europe. ${ }^{7}$ Nieuhof and Dapper's volumes, like so many others that streamed out of the industrious workshops of Holland, were saturated with pictures; and these readily replicable iconographic forms lent themselves, easily and naturally, to the production and reproduction of memory. Pictures preserved memories-or at least, various forms of memories.

This essay examines these pictorial forms of global memory-icons, as it were, of the early modern exotic world; pictures worth (as it turns out) well more than a thousand words. It considers how they obtained and dispersed meaning in their many iterations, and it reflects on how sources of geography functioned to shift and shape new meanings as they moved

6 Johan Nieuhof, Gedenkwaerdige zee en lantreize door de voornaemste landschappen van West en Oostindien (Amsterdam, 1682). This book also incorporated materials from the China volume, Het gezantschap der Neerlandtsche Ost-Indische Compagnie, aan den grooten Tartarischen Cham, den tegenwoordigen keizer van China (Amsterdam, 1665), which advertised (in its full title) its own 'gedenkwaerdighste geschiedenissen'. See further Olfert Dapper, Gedenckwaerdig bedryf der Nederlansche Oost-Indische Maetschappye, op de kuste en in het keizerrijk van Taising of Sina (Amsterdam, 1670); Dapper, Naukeurige beschryving der eilanden, in de archipel der Middelantsche zee, en ontrent dezelve, gelegen (Amsterdam, 1688) and Naukeurige beschryving van gantsch Syrie, en Palestyn of Heilige Lant (Amsterdam, 1677), the full titles of which also invoke the 'memorable' qualities of geography.

7 V.D. Roeper and G.J.D. Wildeman, Reizen op papier. Journalen en reisverslagen van Nederlandse ontdekkingsreizigers, kooplieden en avonturiers, Jaarboek van het Nederlands Scheepvaart Museum Amsterdam (Zutphen: Walburg Pers, 1996). 
from source to source and from medium to medium. It looks, that is, at processes of transmediation: how sources (in this case, images extracted from geography) change in meaning when they transfer to different media, or how the medium, to invoke the famous dictum of Marshall McLuhan, could often be the message. ${ }^{8}$ Finally, it explores how shifts in meaning, or transmediations, might have influenced early modern Europe's 'memory' of the world it was coming to know in this critical age of exploration and empire.

\section{Memorable Khans and Mediated Despotism}

Pictures and prints pertaining to the non-European world, made in the decades surrounding 1700 - from the 1660 s more or less through the 1730 - would have a profound influence over Europe's 'memory' of exotic space. There was a profusion of images produced in all manner of geography - much, if not most, emanating from workshops of the Netherlandsand these representations also circulated broadly across several media. ${ }^{9}$ The very range of these images - in terms of their subject matter, their market range, and the extent of their impact-is highly impressive. The conception of Chinese imperial power, for example, which would later come to define so-called Oriental despotism, derived to a striking degree from the engraved scene of the Qing emperor that opens Johan Nieuhof's 'most memorable' voyage to China, as the title page calls it (figure 12). ${ }^{10}$ First published by Jacob van Meurs in 1665, Nieuhof's account would turn out to be among the most popular works of geography produced in the early modern period. It appeared in something approaching a dozen separate editions - this does not include the numerous pirated and plagiarised versions - and these spanned the major languages of Europe. ${ }^{11}$ Its images, moreover, circulated even more broadly in other publications, other

8 Marshall McLuhan, Understanding media. The extensions of man (New York: McGrawHill, 1964).

9 Benjamin Schmidt, 'Mapping an exotic world. The global project of Dutch geography, circa 1700', in Felicity Nussbaum (ed.), The global eighteenth century (Baltimore and London: Johns Hopkins University Press, 2003), 19-37.

10 Johan Nieuhof, Het gezantschap der Neerlandtsche Ost-Indische Compagnie, aan den grooten Tartarischen Cham, den tegenwoordigen keizer van China. Waar in de gedenkwaerdighste geschiedenissen, die onder het reizen door de Sineesche landtschappen, Quantung, Kiangsi, Nanking, Xantung en Peking, en aan het keizerlijke hof te Peking, sedert den jare 1655 tot 1657 zijn voorgevallen (Amsterdam, 1665).

11 See John Landwehr, VOC. A bibliography of publications relating to the Dutch East India Company, 1602-180o (Utrecht: Hes \& De Graff, 1991). 


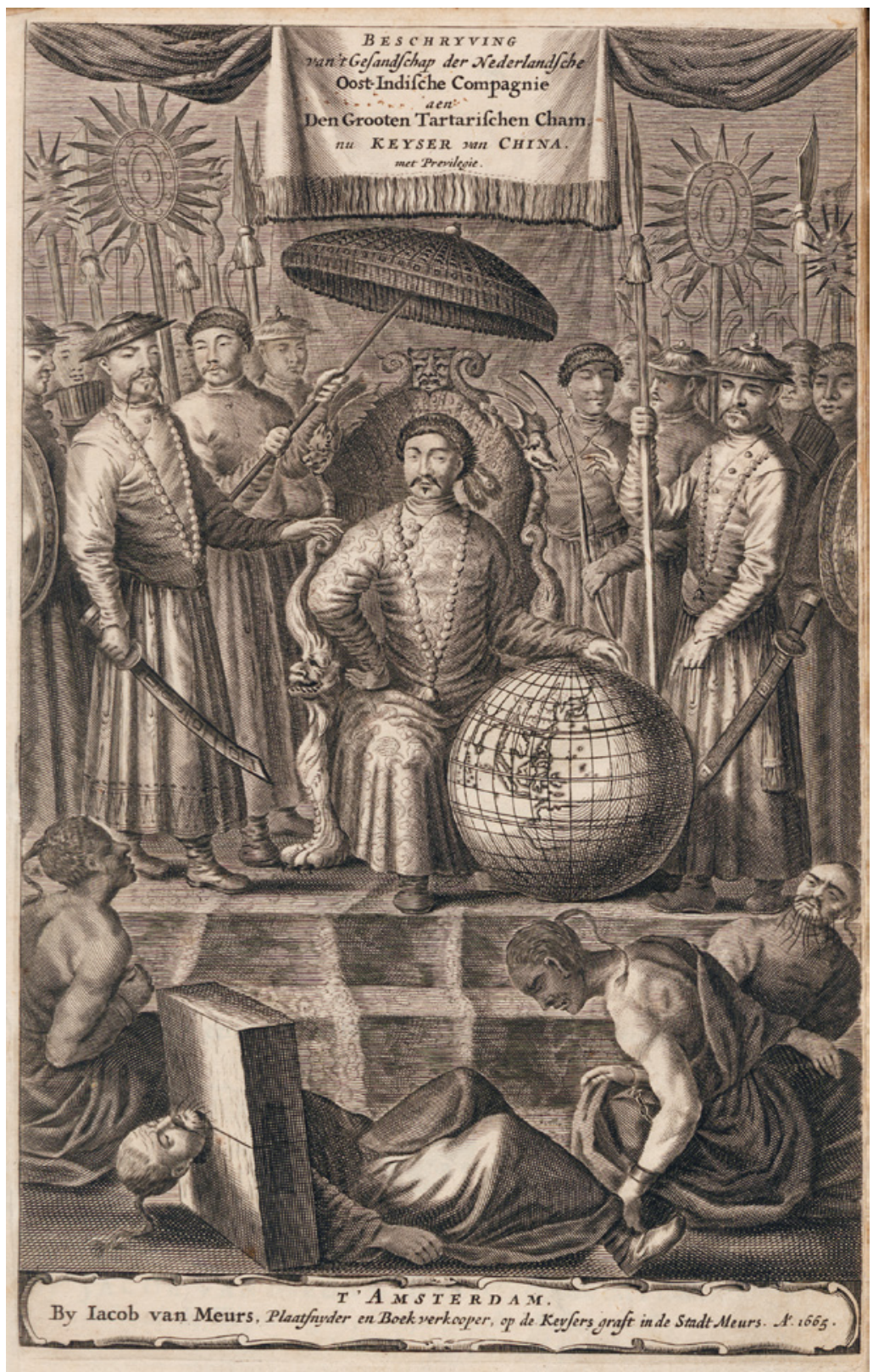

Fig. 12. Jacob van Meurs (workshop), frontispiece of Johan Nieuhof, Het gezantschap der Neerlandtsche Ost-Indische Compagnie, aan den grooten Tartarischen Cham, den tegenwoordigen keizer van China (Amsterdam: Jacob van Meurs, 1665), Universiteitsbibliotheek Leiden, Collectie N.H.K. 345. 
genres, and other media. To the European consumer of the later seventeenth and eighteenth centuries, they became icons of the Orient.

Nieuhof's enormously influential frontispiece was exemplary in this regard. An engraved, full-plate folio that serves as the opening illustration of the volume, the frontispiece centres on a regally dressed figure who sits, one arm akimbo, on a baroquely carved throne. The figure's second arm rests on a bulky globe, which displays the just-discernible outlines of China and its domains; the globe's round form mirrors that of a tilted parasol, which is held aloft by a lackey and crowns both the sitter and his throne. The engraving's protagonist-identified by the title as the Grand Tartar Cham, namely the Great Khan — positively radiates imperial hegemony. Surrounding the mighty, newly instated Qing emperor stands a fierce cadre of men bearing arms and banners, while at his feet a cluster of supplicants writhe in various forms of restraint: chains, manacles, and the cangue. These obsequious prisoners sprawled at the base of the engraving (just above the printer's cartouche) allude to the Khan's total control over his subjects' bodies, and the frontispiece image broadcasts, more generally, a message (also echoed in the text) of Chinese imperial puissance. It speaks, more globally, to contemporary European awe of the Khan's majesty and to the admiration-especially among certain elite European observers - of his absolute political and juridical control.

The image is presented ostensibly as a memory. It is meant to offer a snapshot, as it were, of a moment in Nieuhof's Chinese adventure and a record of a Dutch embassy to the imperial city. Yet a brief glance backward and forward show just how convoluted this memory could be, both in terms of the image's production and its afterlife. First, backward: Although attributed to the volume's putative author, there exists no original draft by Johan Nieuhof for this imaginative imperial passage, as, indeed, there could not be, since the scene did not take place-Nieuhof and his colleagues never actually obtained an audience with the emperor. And while the manuscript from Nieuhof's China voyage does contain an illustrated title page, this image bears no resemblance to the engraved frontispiece of the printed book. ${ }^{12}$ The latter derives, rather, from Van Meurs' workshop and not unlikely from the drafting table of the printer himself, who trained as an engraver. Yet the image does evoke a patina of memory. It extracts the figure for the Great Khan from an on-site drawing made by Nieuhof of

12 For the manuscript, see Leonard Blussé and R. Falkenburg (eds.), Johan Nieuhofs Beelden van een Chinareis, 1655-1657 (Middelburg: Stichting VOC, 1987). 
'an old [provincial] viceroy' whom the author met in his travels (figure 13). This sketched figure wears the same brocaded gown, beaded chain, furlined hat, and jaunty feathers as the engraved emperor. ${ }^{13}$ The printer, in other words, has gussied up this relatively austere, stand-alone sketch with layers of regal extravagance: the armed guards, humbled prisoners, and stately trappings of power. The combination of pomp and power, in all events, proved compelling. For while subsequent portraits of the Great Khan on his own are relatively rare, the imperial entourage appears as such across myriad prints and decorative arts. It served, unrevised, as the frontispiece to the French (1665), German (1666), and Latin (1668) editions of Nieuhof's book, while a copy of the design, mildly modified by the

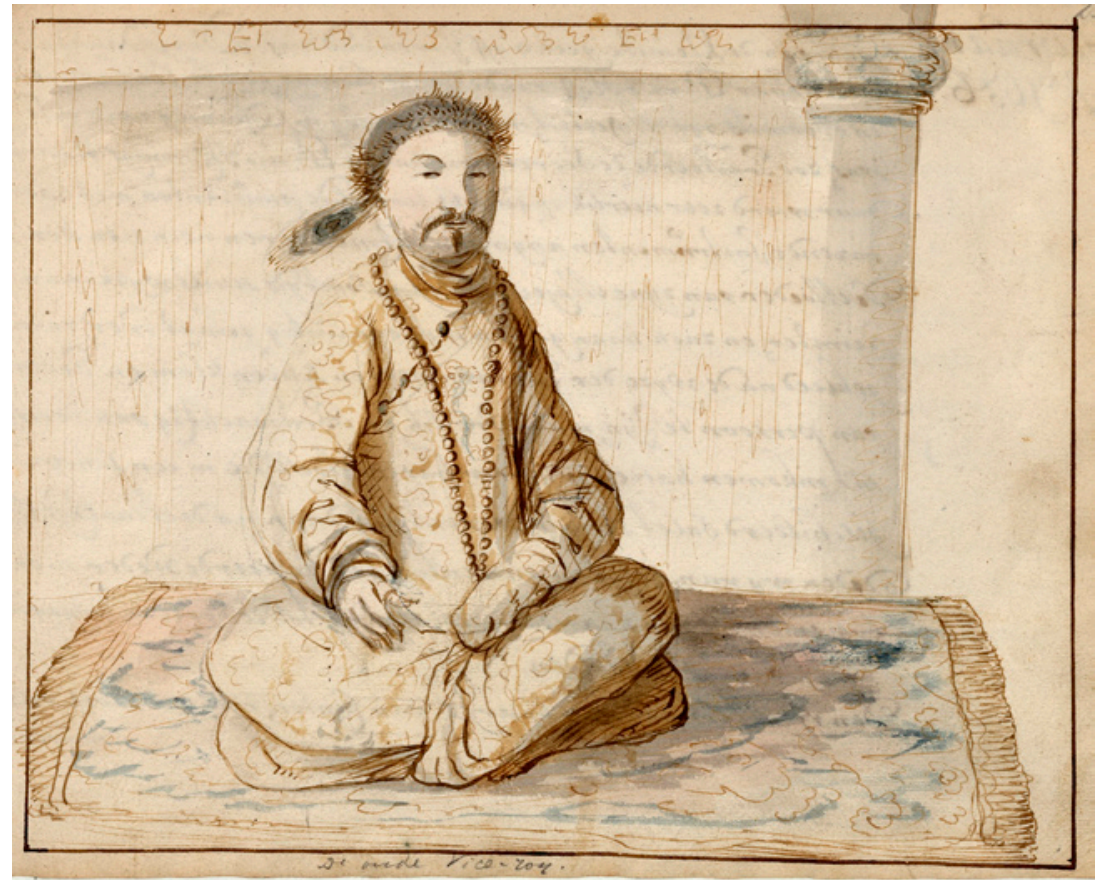

Fig. 13. Johan Nieuhof [?], drawing of a viceroy in 'Journaal van zommige voorvallen, inde voyagie vande E. Heeren Pieter de Goyer en Jacob Keyser, ambassadeurs, aande grootmachtige keizer van Chyna en Tartaryen, inde jaaren 1655, 56 \& 1657' (1659), folio 23; manuscript in the collection of the Société de Géographie, Bibliothèque Nationale, Paris.

13 Blussé and Falkenburg, Beelden van een Chinareis, between pp. 32 and 33. 
Bohemian etcher Wenceslaus Hollar, fronted the English edition of John Ogilby's Atlas Chinensis. ${ }^{14}$ Other, unrelated geographies of China adopted the basic layout of the image: enthroned emperor, flanking attendants, wretched supplicants. And it is highly ironic that the German publisher of Jean-Baptiste Du Halde's well-received Description geographique ... de L'empire de la Chine, a volume that purports to assemble Jesuit experiences in China-and a volume that, inter alia, was highly critical of those 'decorative' Dutch publications-lifted Van Meurs' design largely unchanged. This Du Halde edition appeared in the mid-eighteenth century and thereby indicates just how fixed this picture had become among Enlightened Europeans as an enduring image of imperial China. ${ }^{15}$

Yet, this image was not at all fixed. The memory of 'Nieuhof', massaged from the start, proved to be a thoroughly plastic specimen of memory, which could be further massaged and reconstituted as need be. And just as it would be a mistake to privilege the earlier forms as somehow more correct-Van Meurs' engraved adaptation of Nieuhof's sketched recollection of a vaguely allied figure who came to stand for the Grand Khan - it would also be wrong to fix on the printed figure or on any other single semiotics of the ensemble, or to discount any of the wider-ranging, later iterations of the Emperor of China (as the motif came to be called). For the image of the Khan certainly got around, and it soon moved on to other media, including the material arts, where it 'decorated' a range of goods: ceramics, silver, furniture, tapestry, and so on. And these other forms, needless to say, produced other meanings. Memories of place, that is to suggest, shifted not only with time but also with form; varying materials instigated varying messages. The astonishingly inventive 'Grieksche A Factory' of Delft, the leading European producers of tin-glazed earthenware in the second half of the seventeenth century, manufactured a vase with cover (ca. ${ }_{1675}-80$ ) that featured the emperor and his entourage, transposed virtually unchanged from Van Meurs' print (figure 14). The disciplined Chinese subjects in this arrangement are painted slightly off to the side of the imperial assembly, where a royal servant attends to their punishment. Yet rather than weakening the message of the Khan's omnipotent power, this

14 John Ogilby, An Embassy from the East-India Company of the United Provinces, to the Grand Tartar Cham Emperour of China (London: John Macock, 1669), with a 'second part' published in 1671 (London) as the Atlas Chinensis (not to be confused with the second edition published in 1673).

15 J.-B. Du Halde, Description geographique, historique, chronologique, politique, et physique de L'empire de la Chine et de la Tartarie chinoise, 4 vols. (Paris, P.G. le Mercier, 1735). 


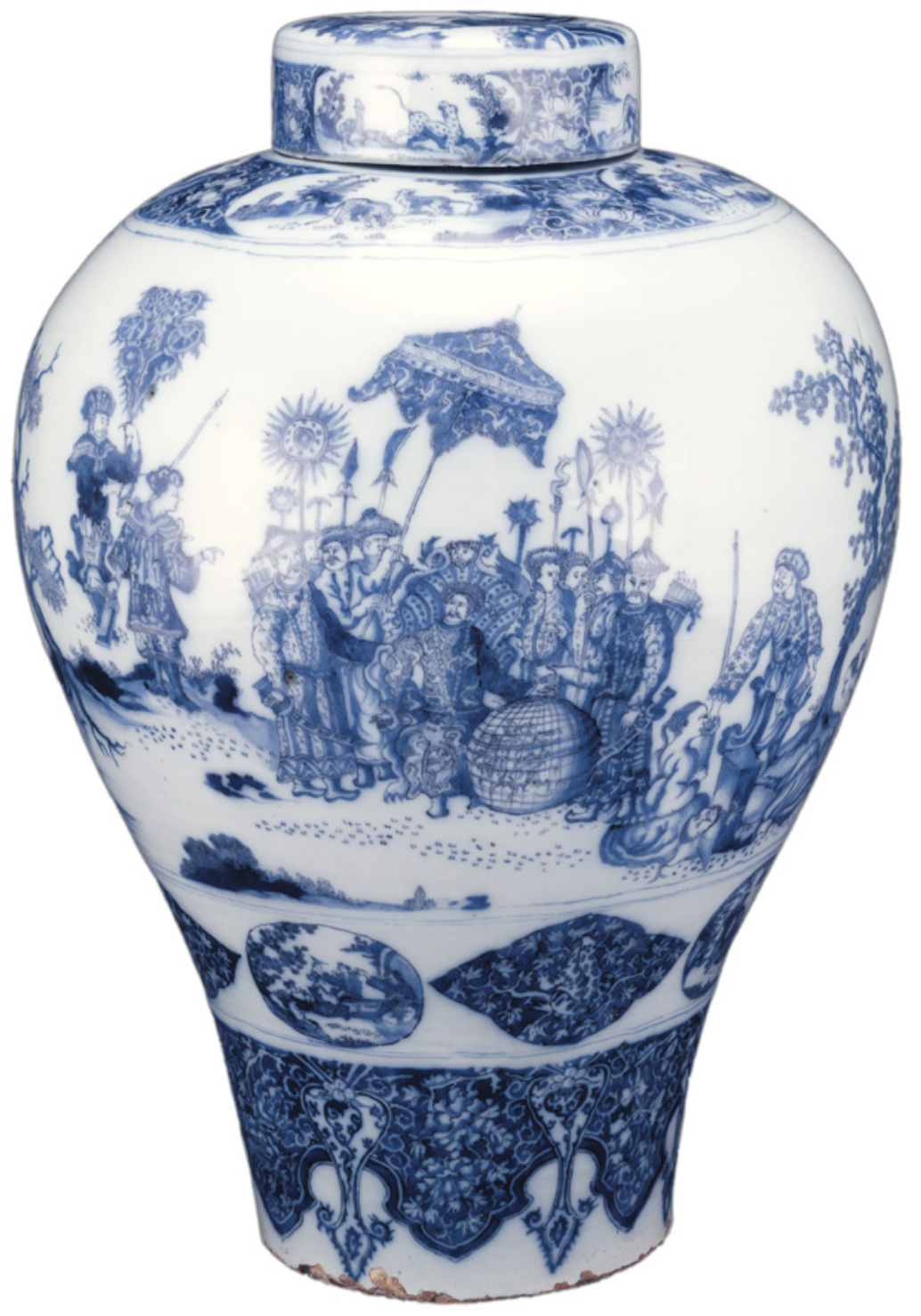

Fig. 14. Vase with Cover, ca. 1675/80, Greek A Factory (attrib.), tin-glazed earthenware, $5^{8} \mathrm{~cm}$ (height), The Art Institute Chicago, Anonymous gift in honor of Eloise W. Martin; Eloise W. Martin Fund. 
circular composition arguably enhances it: the viewer observes imperial control and its collateral damage. Still, the arabesques (top and bottom) and vignettes of exotic fauna (tigers and a rhinoceros), and the simple fact that the vase likely rested on a mantle, surely adjusts and recontextualises the meaning of Van Meurs' print. But rather than emphasise the 'decorative' aspect of the vase, we might draw the opposite conclusions: that so-called decorative arts can convey narrative; and that, in this case, the iconographic impact may not have moved so far from the frontispiece's original message of Qing imperial majesty and political might.

Emperor, entourage, and globe also appear under a tilted parasol on a large oak cabinet veneered with walnut, Brazilian rosewood, and padauk (a tropical wood), and decorated with inlaid pewter. (The cabinet was likely made circa 1700 in the workshop of Hendrik van Soest. Considerably damaged in World War II, it now resides in the Grassi Museum für Angewandte Kunst in Leipzig: see figures 15 a and b. $)^{16}$ In this instance, the original composition has changed in subtle ways - the Khan stands, the attendants recede, and the vignette now includes a richly dressed figure who offers a spread of luxury goods. Yet the side drawers of the cabinet surrounding the central imperial scene incorporate an array of exotic scenes that also derive from various, not directly related, Van Meurs' prints; and these further illustrate forms of imperial justice and control, particularly practices of Chinese legal torture (figure 15). The multiplication of somatic punishment in these images intensifies the impression of absolute imperial power, while the medium itself-exotic woods used to exhibit exotic motifs—only reinforces this message.

Another instance demonstrates even more clearly the wisdom of McLuhan's bon mot on media and messaging. A series of tapestries designed by Guy-Louis Vernansal and manufactured in the Beauvais workshops make numerous references to the Van Meurs frontispiece, along with other prints from the Nieuhof volume, in its illustration of 'The Story of Emperor of China' (as the tapestries are collectively known). In 'The Emperor on a Journey,' for example, the Great Khan sits, one arm akimbo, under an intricately designed canopy that shades a majestic throne-cum-palanquin. He is borne by attendants and accompanied by mounted escorts who bear arms and royal banners. Although the medium in this instance is neither

16 The full, undamaged cabinet is reproduced in Otto Pelka, Ostasiatische Reisebilder im Kunstgewerbe des 18. Jahrhunderts (Leipzig: Hiersemann, 1924). See also Renate Eikelmann, Die Wittelsbacher und das Reich der Mitte. 400 Jahre China und Bayern (Munich: Hirmer Verlag, 2009). 


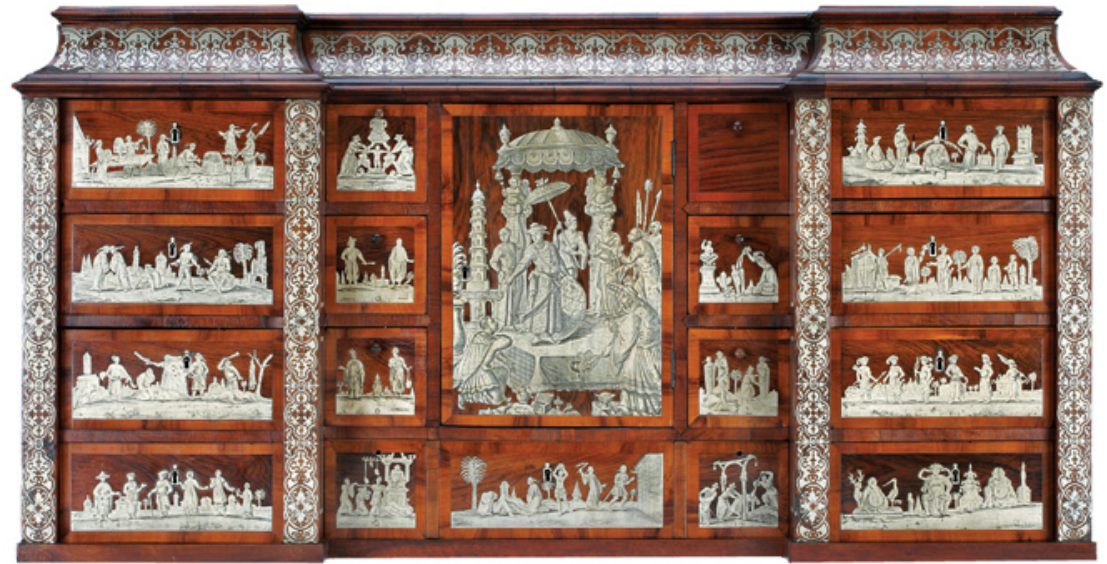

Fig. 15a. Hendrik van Soest (attrib.), Cabinet, ca. 1700, oak veneered with walnut, Brazilian rosewood, and padauk, decorated with inlaid pewter, Grassi Museum Für Angewandte Kunst, Leipzig.

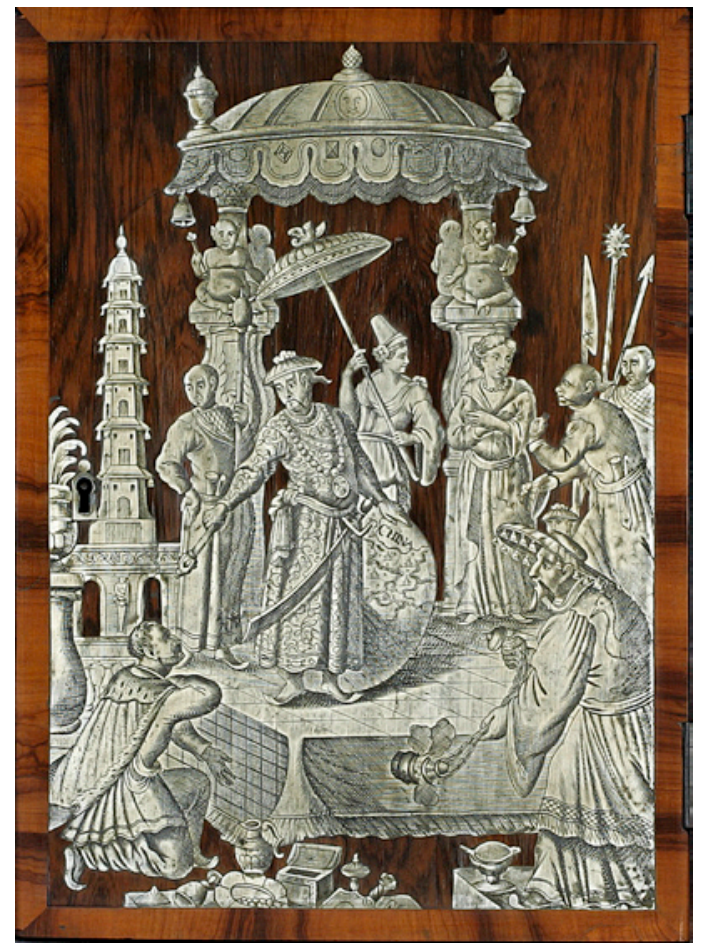

Fig. 15b. See fig. 15a. Central panel with image of the Chinese emperor. 
inherently exotic (like the tropical woods) nor formally so (like the blueand-white delftware), the message of the magnificent tapestry meshes well with the motifs of the original print: a textile fit for a prince displays the grandeur of the Chinese emperor. While it is not unusual in the European tradition to enlist large-scale tapestry for grandiose themes, the medium's deployment for 'The Story of Emperor of China' well serves this exotic, imperial narrative. More generally, while the Van Meurs frontispiece certainly travelled extensively and circuitously-from print to vase to cabinet to tapestry and so on-its mediations functioned productively, by and large, to adjust and augment the original message of what would come to be known as Oriental despotism. And while specific meanings may have shifted in individual pieces only subtly, the objects indicate collectively a more fundamental and substantive shift: In the form of a blueand-white vase, a sumptuously inlaid cabinet, and a princely designed tapestry, the original 'memory' of a putative encounter between Johan Nieuhof (and the Dutch embassy) with the newly instated Qing emperor (and his entourage) has fallen by the wayside. We have long since left the terrain of diplomatic exchange and have quietly slipped into the world of chinoiserie.

\section{Memories of Mendicants and Mandarins, or How Torture Entered the Early Modern Bedroom}

Seemingly sturdy memories can turn out to be wobbly, needless to say, and so can the texts and images that convey them. This applies especially to memories and knowledge of the exotic world - the global fare peddled in sources of early modern geography — which necessarily travelled great distances to reach consumers and left themselves open therefore to numerous imprecisions and possible interventions. Perhaps to compensate for its extensive peregrinations, geographic knowledge was typically passed off as personal account and on-site observation. Yet volumes of exotic geography were rarely the product of any singular 'author' - this applies to individual narratives such as Nieuhof's no less than to impersonal 'descriptions' (beschrijvingen) such as those of Dapper. The images that illustrate these accounts, moreover, were almost never made from bona fide witnessing (despite the persistence of this claim on the title page). When the Calvinist predikant Philip Baldaeus described for his readers the religious practices of Southern India-his self-reported 'memories' of a sojourn in Malabar, Coromandel, and Sri Lanka to observe the 
spiritual mores of the indigenes—-he borrowed said memories ('pillaged' may be too strong a word) from the manuscripts of those Jesuit missionaries who had covered this terrain a half century earlier. The images used to illustrate his account-'drawn to the life' (na 't leven), according to the title-page's breezy assertions-derived from a manuscript gifted to the Dutch governor Rijcklof van Goens by the artist Philips Angel, who had acquired and translated a journal penned by the Jesuit missionary Jacopo Fenicio. The latter had copied his images (including the volume's celebrated representation of the ten avatars of Vishnu) from a Gujarati (namely, Northern Indian) artist executed several years earlier. Baldaeus' testimony thus is not a personal memory at all—at least not in the conventional way we think of a distinctive, private memory-but rather a constructed or perhaps self-fashioned narrative, an elaborate form of cross-cultural 'telephone' wherein the starting and end points are separated by enormous gulfs of culture and context: Gujarati Hinduism, Jesuit Catholicism, Dutch Calvinism, and so on. Such forms of memories are much handled, and much gets lost (and found) in translation. ${ }^{17}$

Much gets lost and found in transmediation, as well, and this points to the material and multimedial quality of these early modern global memories. The transformation and manipulation of basic textual and graphic sources in the medium of print — words and pictures — are hardly unique. These are standard tricks of the book trade, and they cross many genres. Rather different, however, is the material transformation of imagery and motifs, or what I have been calling its transmediation: the movement of images, traces, and graphic 'memories' across media, in particular from books into material arts or what would come to be called decorative arts, and their subsequent transformations in terms of meaning. ${ }^{18}$ These transformations occurred relatively commonly to the sort of exotic motifs exemplified by the frontispiece image of emperor of China. More generally it is fair to say that exotic imagery moved easily from print

17 Philip Baldaeus, Naauwkeurige Beschryvinge van Malabar en Choromandel, der zelver aangrenzende ryken, en het machtige eyland Ceylon. Nevens een omstandige en grondigh doorzochte ontdekking en wederlegginge van de Afgoderye der Oost-Indische Heydenen (Amsterdam, 1672); Ellinoor Bergvelt and Reneè Kistemaker, De wereld binnen handbereik. Nederlandse kunst- en rariteitenverzamelingen, 1585-1735, 2 vols. (Zwolle: Waanders and Amsterdam: Amsterdams Historisch Museum, 1992), vol. 2 [catalogue], 186-187.

18 Cf. Craig Clunas, Pictures and visuality in early modern China (London: Reaktion Books and Princeton: Princeton University Press, 1997), 46, which develops a similar idea of 'iconic circuits': 'an economy of representations in which images of a certain kind circulated between [sic] different media in which pictures were involved.' 
to material arts. And this prompts the more particular question: what happens when memories of, in this case, extra-European places and things become material or 'decorative'?

An altogether different trajectory of exotic motifs can be traced back to another set of Nieuhof-derived sources, although in this case the imagery derives from a more concrete memory, a personal experience Nieuhof records in his journal on 20 May 1656, as he does other journal entries, 'for remembrance' (tot gedachtenis). On that day, while waiting on the banks of the Yangtze River not far from Nanjing, the Dutch trade delegation encountered a motley crew of local men, a scene Nieuhof worked up in a briskly executed sketch in pen and wash (figure 16). ${ }^{19}$ The figures in Nieuhof's drawing appear in an indeterminate landscape-dim allusions to mountains fill the background, yet there are no obvious signs otherwise of an exotic setting: no palms, no parasols, no pagodas-and following pre-modern conventions of composition, several distinct vignettes are combined in a single frame. The accompanying text (presumably also by Nieuhof) clarifies the subject: these are assorted beggars who perform a range of caprioles, or capers, to solicit charity from passers-by. The image offers several rich veins of inquiry - why, one wonders, is the head of the central figure so vividly aflame?-among the most curious and productive of which is the depiction of two men on the left, who hoist menacing boulders above their heads. As the narrator explains, these are blind men who, marching in order, pound stones mercilessly into their bare chests and backs 'until blood spews out'. ${ }^{20}$ And although Nieuhof seems unmoved by this garish display of masochism, a sly comment about his own belief in the Christian god suggests that he intuitively understood the sacred context of the performance: these are roadside ascetics, affiliated with the figure standing on the right, a priest, who ministers to the faithful. The sketch recollects-quite concretely and memorably-popular religious practices of early modern China.

As it turns out, this was just the beginning of the blind beggars' journey and of this particular memory's iterations. A decade or so later, the sketch was worked up in Jacob van Meurs' atelier and integrated into a print (1665), where the original meaning was partly maintained-the picture bears the title 'Mendicants,' alluding to the social context of the original drawing - yet the blind man's belly is now more comically

19 Blussé and Falkenburg, Beelden van een Chinareis, f. 101 (between pages 42 and 43).

20 Ibid., f.101 (page 44). 


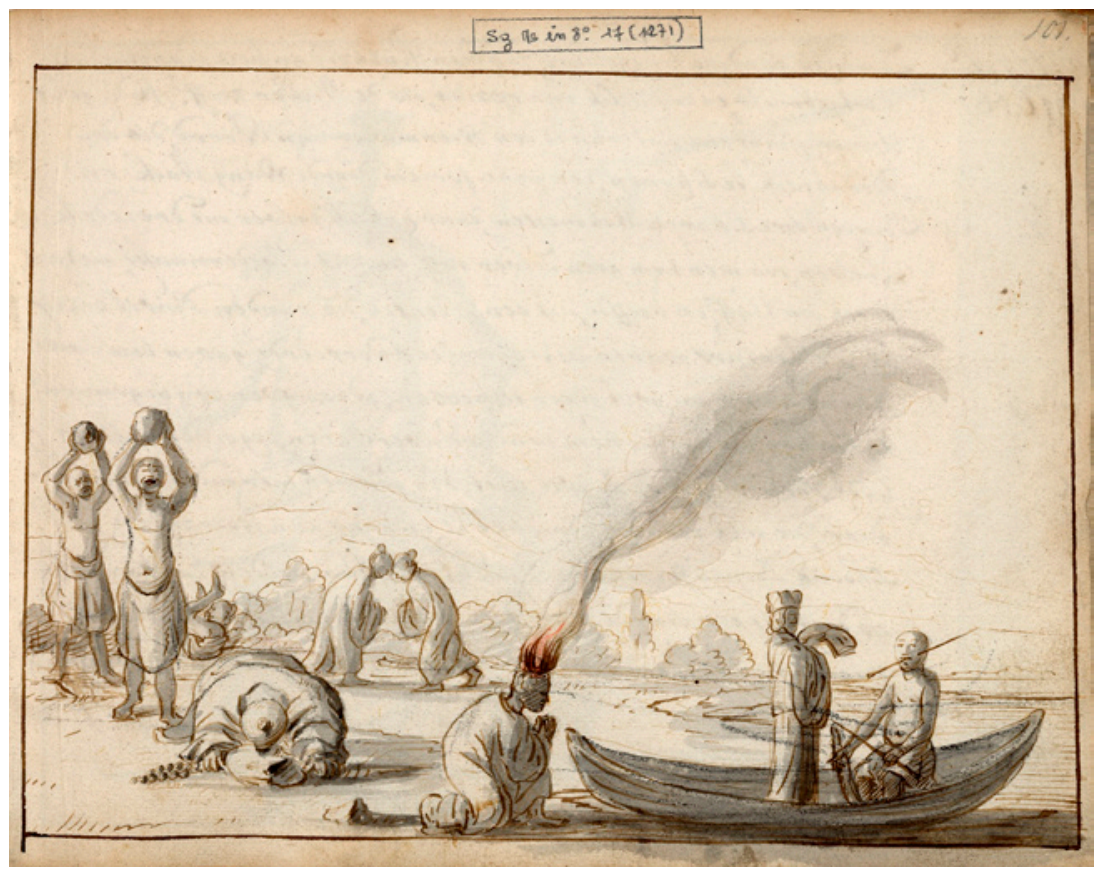

Fig. 16. Johan Nieuhof [?], drawing of ascetics in 'Journaal van zommige voorvallen, inde voyagie vande E. Heeren Pieter de Goyer en Jacob Keyser, ambassadeurs, aande grootmachtige keizer van Chyna en Tartaryen, inde jaaren 1655, 56 \& 1657' (1659), folio 101; Société de Géographie, Bibliothèque Nationale, Paris.

portly, and he joins not only the fiery figure (once again in the centre), but a wholly unrelated man in a cangue (figure 17). Very soon after that, the mendicant materialised in a painting (ca. 1666) by Jan van Kessel, where he joins a mélange of characters that includes several other members of the original cast of mendicants. Taken altogether, these figures, along with the background pagoda and several other things associated with the East, are meant to indicate all things Oriental. This is one of four Van Kessel allegories of continents, and the sum of the parts is meant to delineate the whole of 'Asia': a sweeping conflation that juxtaposes Chinese ascetics and turbaned Persians, Ottoman mosques and Buddhist statuary. ${ }^{21}$ The beggar, in all events-but one of many Asiana

21 Dante Martins Teixeira, The 'Allegory of the continents' by Jan van Kessel 'the elder' (1626-1679). A seventeenth-century view of the fauna in the four corners of the earth (Petrópolis: Index, 2002). The painting, Asie, is in the Alte Pinakothek, Munich. 


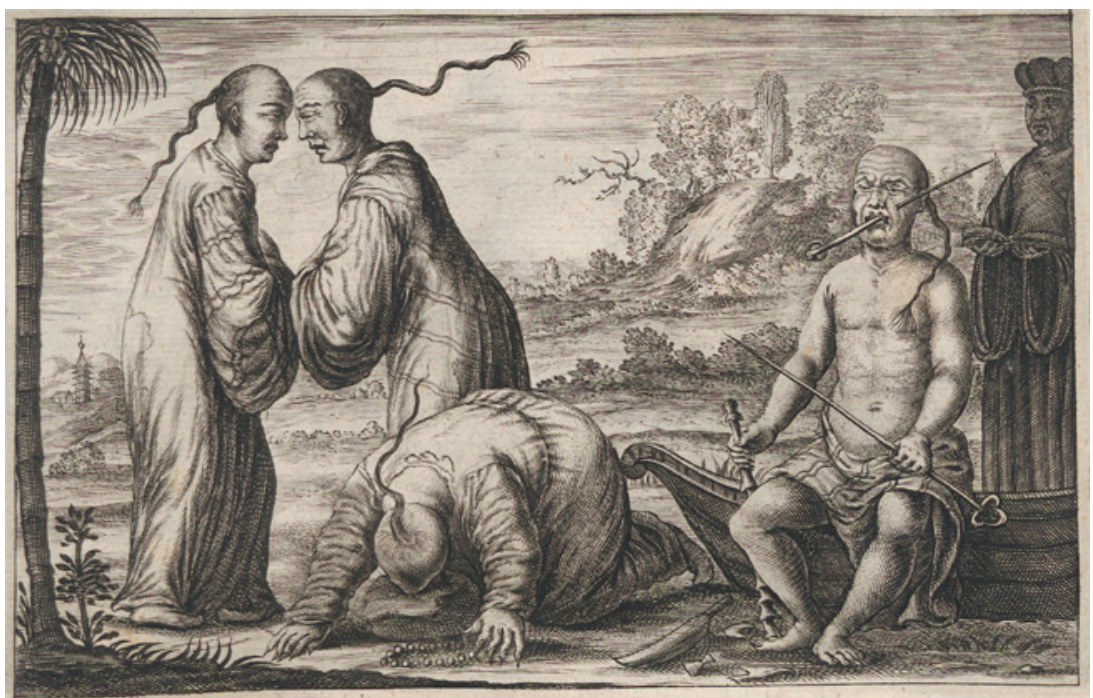

Fig. 17. Jacob van Meurs (workshop), "Mendians," engraved illustration in Johan Nieuhof, Het gezantschap der Neerlandtsche Ost-Indische Compagnie, aan den grooten Tartarischen Cham, den tegenwoordigen keizer van China (Amsterdam: Jacob van Meurs, 1665), vol. 2, p. 35, Universiteitsbibliotheek Leiden.

in Van Kessel's panel-marched on. He appeared also on a ceramic tableau made in Delft (ca. 1680-1700), where he plays the part of a strongman in a band of circus performers (mice dance beside him to the beat of a tambourine). And, after that gig, he turns up on the Grassi veneered cabinet, reunited with the not-quite flaming head (which he now readies to smash) and the stocked prisoner, who collectively make up a scene of sundry corporal punishment-Asian, one presumes, from the iconic palm trees (See figure 15a, bottom-center drawer).

It is worth noting that that these mendicants come and go with nonchalance, their place and meaning scarcely fixed. Van Meurs actually engraved several mendicants in a pair of prints (figures 17 and 18), and the lot of them undergo similar transmediations, both in clusters and on their own. Heads beat and burn on another sample of delftware: a large punch bowl, signed by Samuel van Eenhoorn (ca. 1680), which would have been used for hearty drinks after the hunt or in other carousing contexts (figure 19). And banging reverts to restrained prostration in a Rouleau vase, decorated by Ignaz Preissler around 1720. If this last rendition seems more decorous than its predecessors-it reproduces the middle mendicant of the first print (figure 17) who appears to be praying or kowtowing-, 


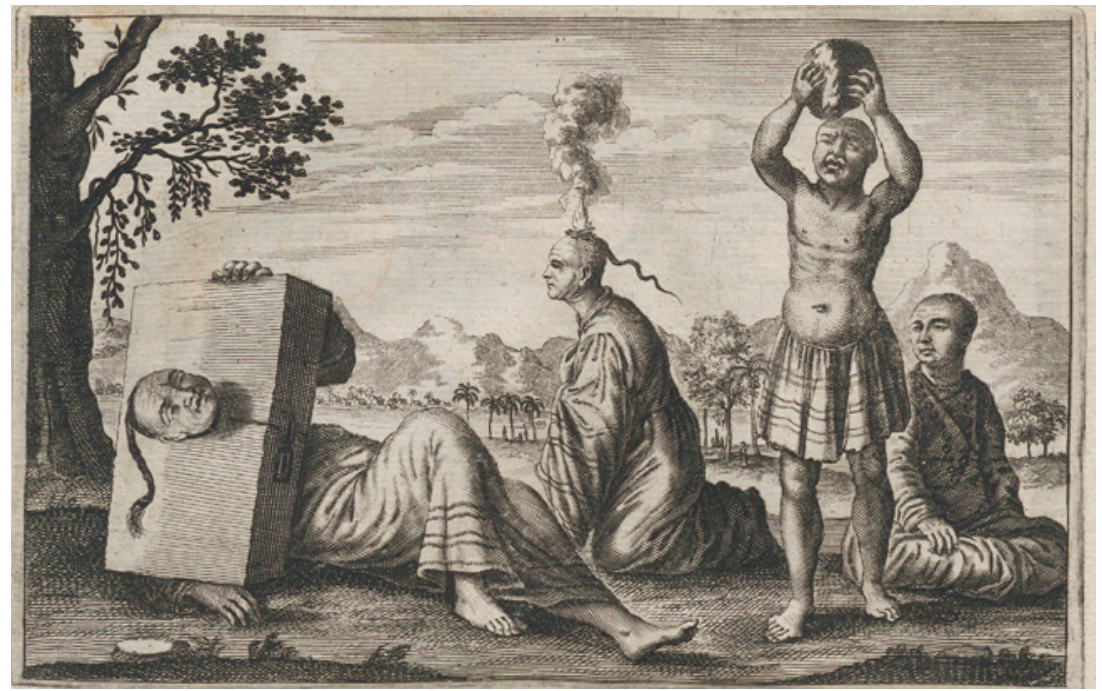

Fig. 18. Jacob van Meurs (workshop), "Mendians," engraved illustration in Johan Nieuhof, Het gezantschap der Neerlandtsche Ost-Indische Compagnie, aan den grooten Tartarischen Cham, den tegenwoordigen keizer van China (Amsterdam: Jacob van Meurs, 1665), vol. 2, p. 36, Universiteitsbibliotheek Leiden.

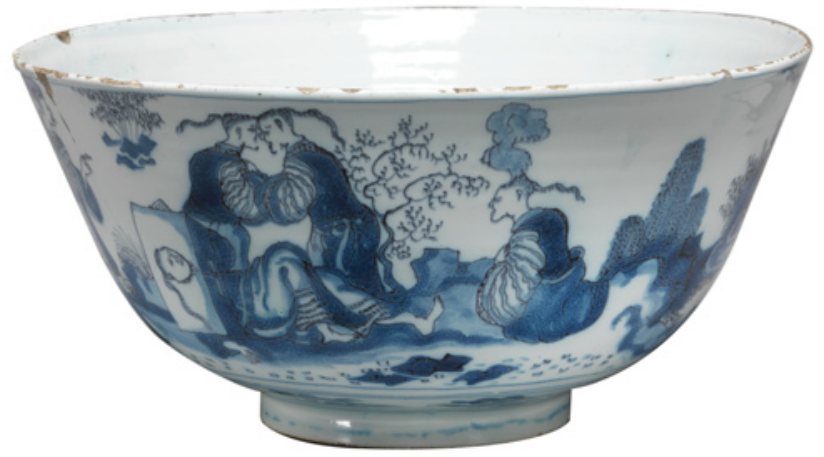

Fig. 19. Samuel van Eenhoorn, Greek A Factory, Punch bowl, tin-glazed earthenware, (ca. 1680), The Fitzwilliam Museum, Cambridge. 
that may owe to its extraction from a pattern book by Johann Christoph Weigel, which codified the image of this particular mendicant, albeit in an altered setting and with a revised meaning. Rather than the original emphasis on bodily harm and endured pain - the original image makes a point about religious practices in rural China-the message is now predicated on fantasy and pleasure. This is most certainly the sense suggested by the long-wandering exotic mendicant who appeared in the Bavarian pleasure palace Amalienburg on the grounds of Nymphenburg, by now a kowtowing prop for a prancing squirrel. ${ }^{22}$

Yet another mendicant leads us down yet another trail, prompted, yet again, by distant memories of the exotic world. The cangued figure in one of the two Van Meurs prints relates to no original drawing we know of-and presumably to no documented memory-yet it does resemble an image implicitly ascribed to Nieuhof: the frontispiece depiction of the dreadfully suffering subjects (including one in a cangue) who beseech the Great Khan for mercy (see figure 18 and compare figure 12). This image certainly implies memory: it opens and gives visual form to a volume of self-declared 'memorable occurrences' in the East. Yet the image also serves, more subtly, to arrest the reader-viewer's attention in a strikingly memorable way. A form of portable pillory used for corporal punishment in pre-modern China and an object of great fascination to early modern Europeans, the Oriental cangue - the object occurred, of course, also in the Occident, for example in New England-appeared in several Dutch-made prints spanning several publications. It came to stand for the power of the Great Khan over his subjects' bodies (as in the Nieuhof frontispiece) and for habits of 'popular' asceticism among exotic 'mendicants.' This popularity soon ushered the image from prints to material arts. Among the chief sources mediating this transition was John Stalker and George Parker's Treatise of Japaning and varnishing, a how-to book for the art of lacquer. ${ }^{23}$ The Nieuhof-inspired cangued figure, as rendered in the lacquer manual, is slyly extracted from its original imperial setting: gone is the central figure of the Khan. This revised version, rather, serves Stalker and Parker as décor for an inkstand or comb box (as they advise the practitioner): a slick pastiche of corporal punishment for the well-provisioned gentleman. Another pattern offered in the Treatise of Japaning, likewise derived from

22 See Ulrike Kiby, Die Exotismen des Kurfürsten Max Emanuel in Nymphenburg (Hildesheim: Georg Olms, 1990) 79-80 and 274-75.

23 John Stalker [and George Parker], A treatise of Japaning and varnishing, being a complete discovery of those arts (Oxford: John Stalker, 1688). 


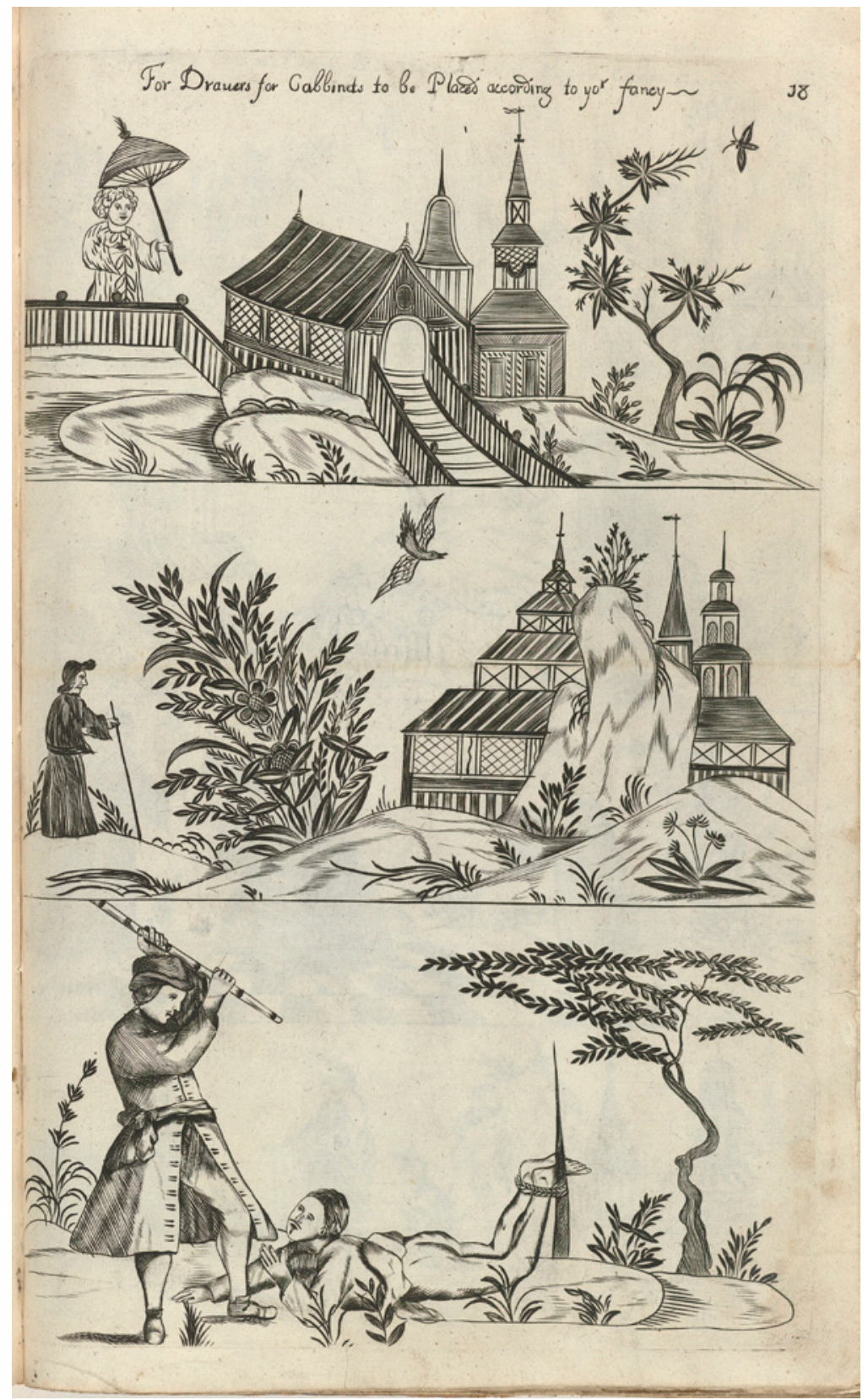

Fig. 20. John Stalker and George Parker, "For Drawers for Cabbinets to be Placed according to your fancy" (plate 18), engraving in Stalker and Parker, A treatise of Japaning and varnishing (Oxford: John Stalker, 1688), Rijksmuseum Amsterdam. 
a printed geography book and lately redesigned by Stalker and Parker 'for [the] cabinets' of a gentleman, shows an even more disturbing image: the methodical thrashing of a bare-buttocked prisoner with a bamboo cudgel, a technique of torture traditionally referenced in modern sources by its Spanish name, the bastinado (figure 20).

In this case, we can trace the image backward as well as forward, and thereby follow its transmediations from personal, site-specific memoryan image in a discreet time and space - to provocative, readily adaptable décor. Looking backward, then forward: Stalker and Parker borrowed the caning pastiche from another Van Meurs publication, in this case Olfert Dapper's account of the 'memorable affairs' of the Dutch East India Company in China. ${ }^{24}$ Textual references to caning merited two engravings from Van Meurs' atelier. In one the victim is a mandarin, identified by the garments strewn about in the foreground; the victim faces a bland landscape on the wall, while a casual witness peers in from an open window (figure 21). In the second print the subject lies grimacing, face in dirt, while a handful of other prisoners cower in the background, naked in the cold air as they await their turn (figure 22). Both images pertain to descriptions of the Chinese legal system: they depict the public spectacle of imperial justice - wrongly, scholars have pointed out ${ }^{25}$ — and the awesome power it had over the body public. Stalker and Parker's rendition, taken directly from the open-air scene, streamlines and repurposes the Van Meurs engraving and subtly changes its meaning. Absent are the background edifices and throng of victims; meanwhile, the efficient executioner is replaced by a well-dressed figure whom the victim implores for mercy (compare figures 20 and 22). While the Van Meurs image underscores the power of the judicial system and the emperor by extension-present metonymically in the grand architecture placed in the rear-Stalker and Parker personalise the exchange, granting discretion to the caner. Indeed, they may undermine the original message of the emperor's sole legal authority. More to the point, Stalker and Parker bring the image into a domestic setting. And this is even more the case for two 'scenes of caning' done on embroidered silk wall-panels, created for a South German

24 Olfert Dapper, Gedenckwaerdig bedryf also known by its English title, the Atlas Chinensis.

25 Timothy Brook, Jérôme Bourgon and Gregory Blue, Death by a thousand cuts (Cambridge, Mass.: Harvard University Press, 2008). See also Jérome Bourgon, 'Chinese executions. Visualising their differences with European supplices', European Journal of East Asian Studies 2, no. 1 (2003), 153-184. 


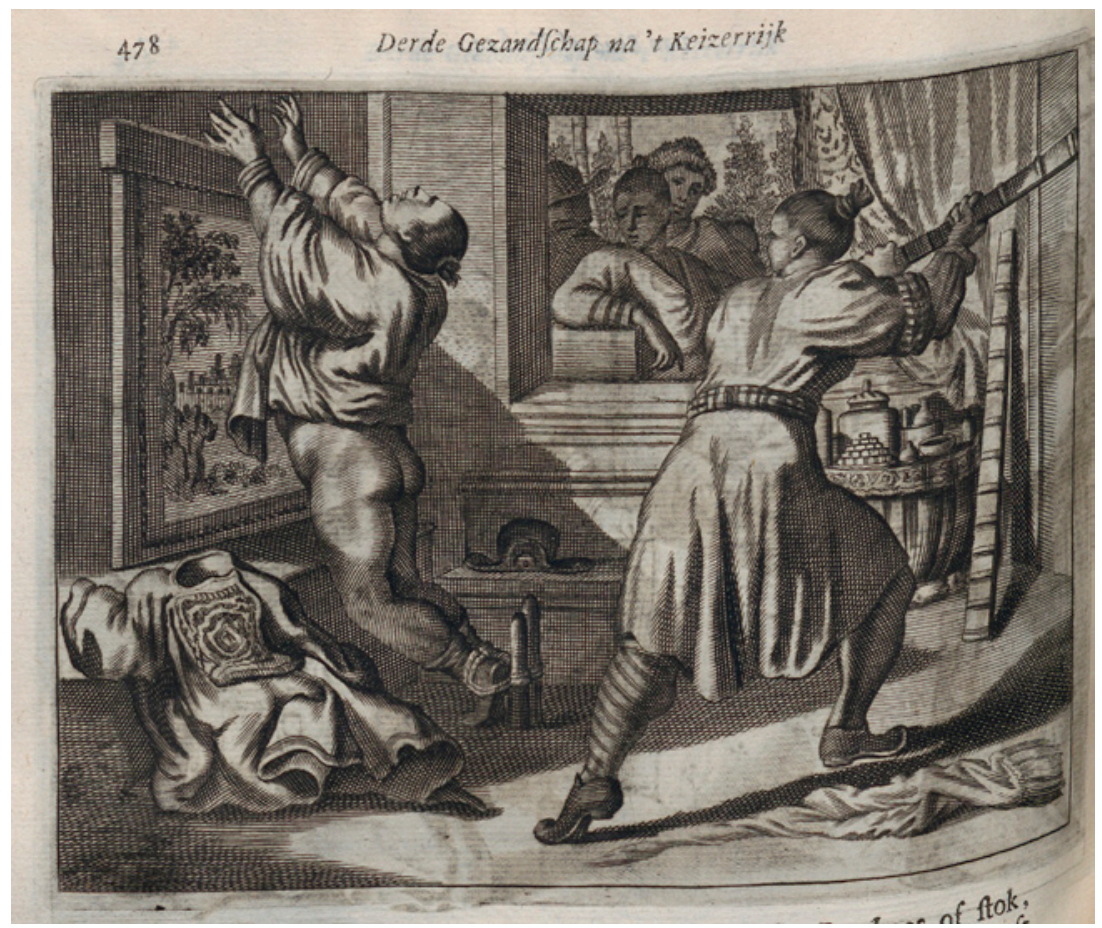

Fig. 21. Jacob van Meurs (workshop), "Caning", engraved illustration in Olfert Dapper, Gedenckwaerdig bedryf der Nederlansche Oost-Indische Maetschappye, op de kuste en in het keizerrijk van Taising of Sina (Amsterdam: Jacob van Meurs, 1670) p. 478, Universiteitsbibliotheek Leiden.

drawing room and later deployed for a Bavarian bedroom (figure 23). ${ }^{26}$ This vignette combines Dapper-Van Meurs' two images, includes the background architecture, and inserts two conspicuous palms, which serve to enhance the exotic flavour of the scene. Yet the care of the scene-setting notwithstanding, the purposeful depiction of a caning pastiche prompts an obvious question: Why would early modern Europeans put scenes of torture in their bedroom? This, in turn, recalibrates our broader inquiry into form and meaning: How are memories transformed when they move from text to artefact, print to design, and book to bedroom?

Looking further backward is further helpful. Original sketches do exist for the caning images, and while these are altogether detached from the text compiled by Dapper, a hack writer at best, they are intimately con-

26 Eikelmann, Die Wittelsbacher und das Reich der Mitte, 264-269. 


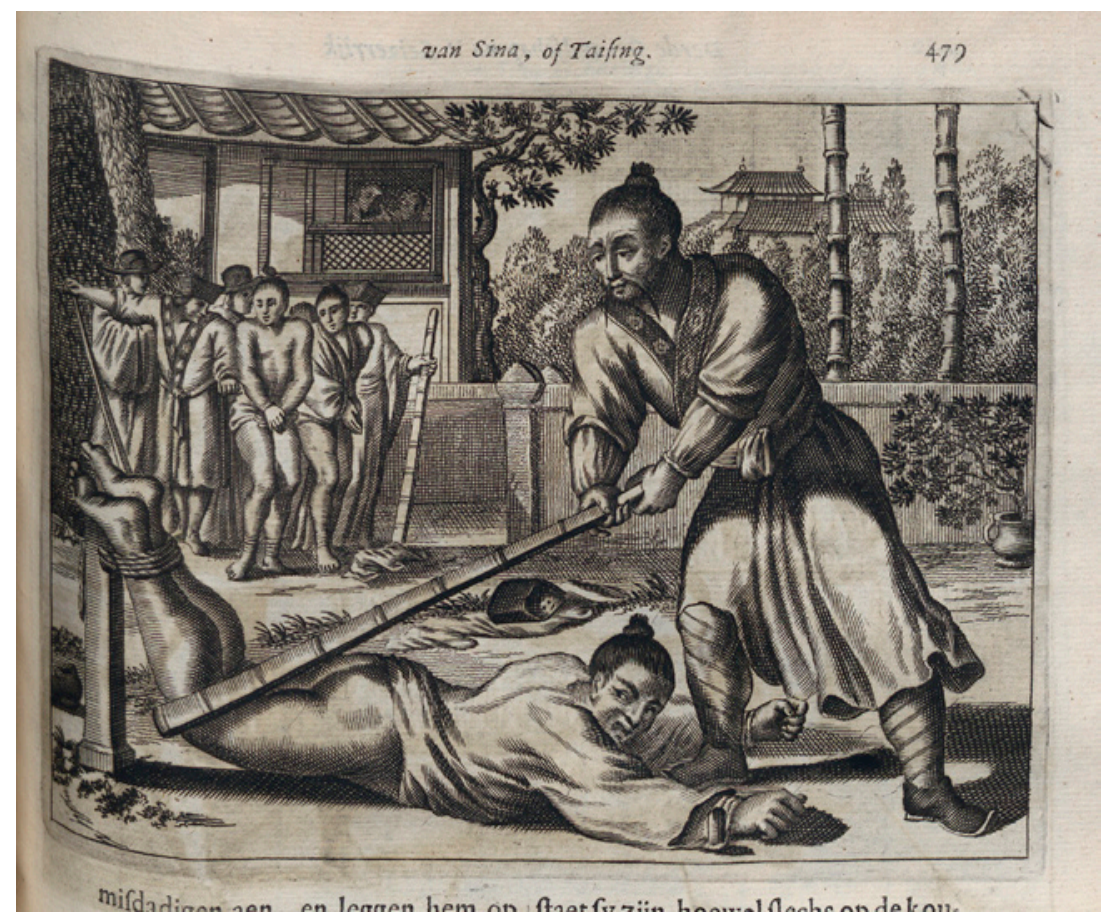

Fig. 22. Jacob van Meurs (workshop), "Caning”, engraved illustration in Olfert Dapper, Gedenckwaerdig bedryf p. 479, Universiteitsbibliotheek Leiden.

nected to a particular memory. Dapper worked for his publisher, Jacob van Meurs, in the business of geography. ${ }^{27}$ The source for caning, by contrast, came from the Jesuit scholar and intrepid traveller, Adriano de las Cortes, who spent time in China and composed a genuine and 'memorable' description of the regime in 1625 - a full century before caning enters the European bedroom. ${ }^{28}$ De las Cortes offers an entirely stripped-down depiction of caning (figure 24). He emphasises, if anything, the rank of the guilty party - no one is above imperial rule - a point alluded to by the victims' hats and tunics. Text and image underscore the disciplined, workmanlike labours of the executioner, a mere servant of the Ming emperor-Ming, since the sketches date from the moment the Ming were just fending off Manchu invaders. Relations with the elite classes of the

27 John E. Wills, Jr., 'Author, publisher, patron, world. A case study of old books and global consciousness', Journal of Early Modern History 13 (2009), 375-433.

28 Adriano de las Cortes, Le voyage en Chine d'Adriano de las Cortes, s j, 1625, ed. Pascale Girard, trans. Pascale Girard and Juliette Monbeig (Paris: Chandeigne, 2001). 


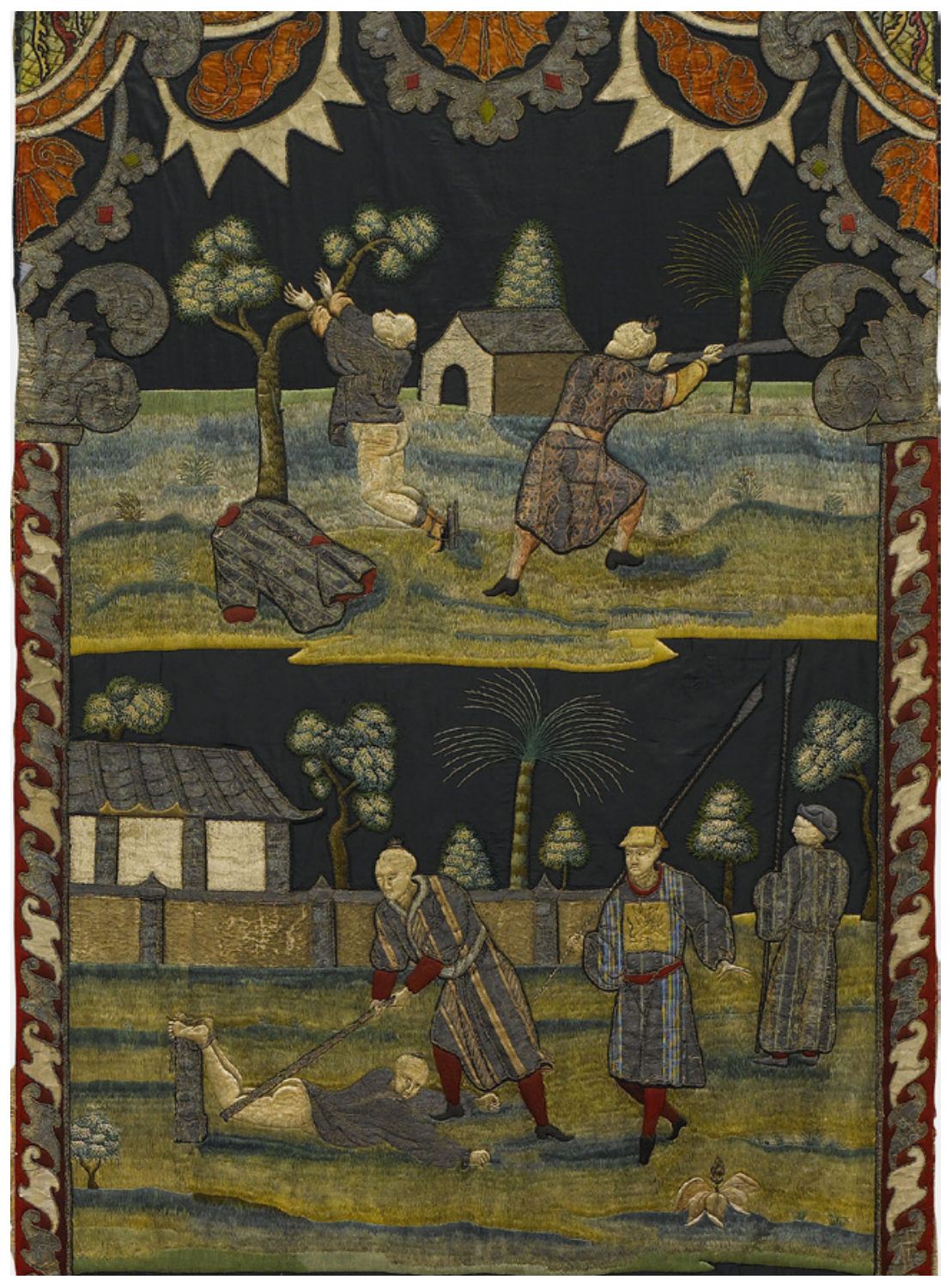

Fig. 23. Wall panel, silk with linen, ca. 1700, $328 \mathrm{~cm}$ (height) $\times 96$ (width per panel) Bayerische Verwaltung der staatlichen Schlösser, Gärten und Seen, Residenz München. 


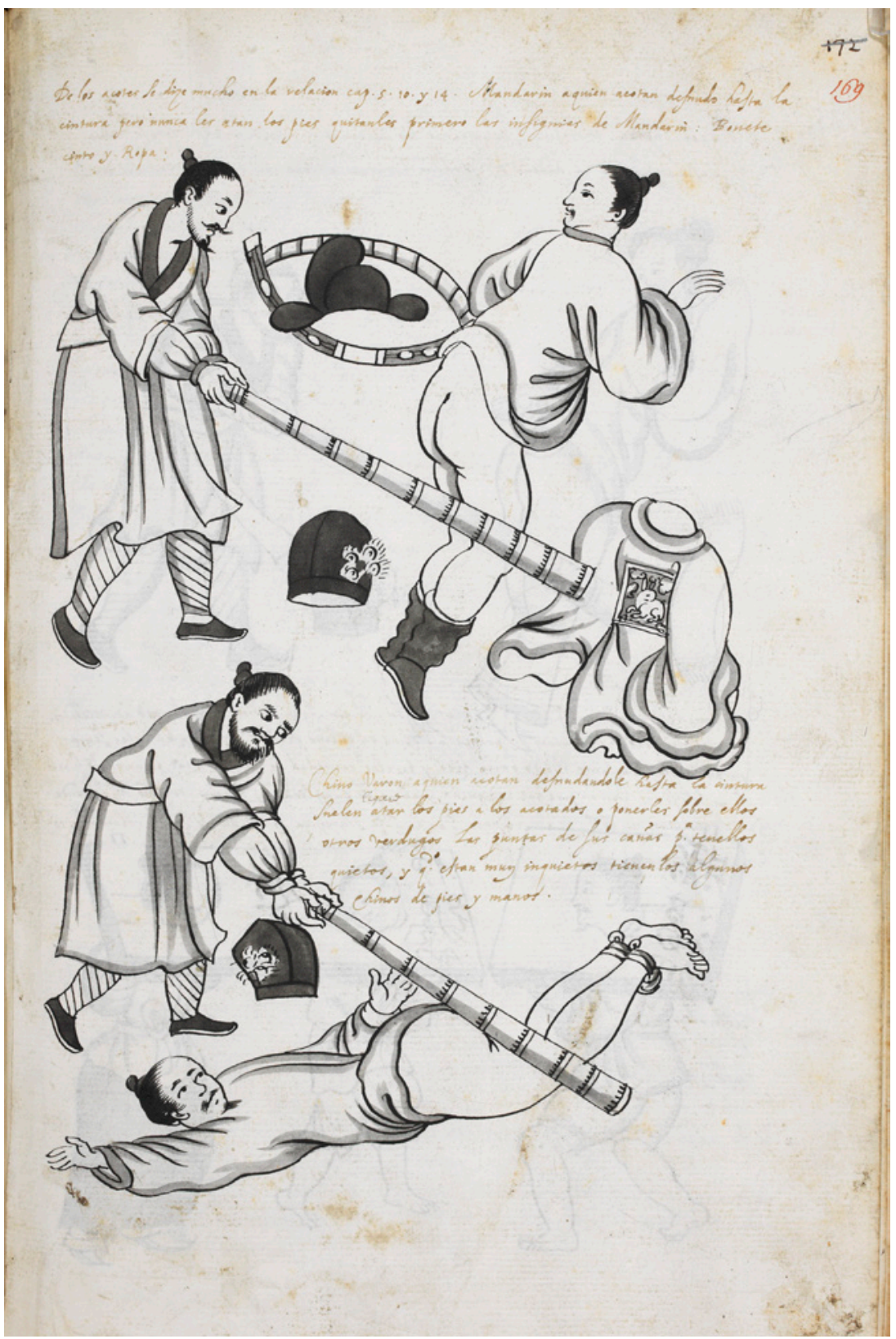

Fig. 24. Adriano de las Cortes, 'Relation, with drawings, of his voyage, shipwreck, and captivity at Chanceo in China: 1621-1626', fol. 169 recto, British Library, mss. Sloane. 
regime were vital to de las Cortes and his Jesuit patrons, whose project of evangelisation entailed forming alliances with high-ranking officials. In the context of de las Cortes' manuscript, this bona fide, reportedly eyewitness, assuredly memorable experience and the knowledge it conveyedpolitical and judicial insights into how the imperial Ming government operated, with tactical religious implications-had a practical, precise, and pressing purpose. Yet this manuscript lay unpublished for nearly four centuries. In the hands of Van Meurs, by contrast, and in the medium of print - print that successfully and profitably crossed confessional and linguistic lines — de las Cortes' memories and images are transformed to make a hazier point about Oriental power and imperial 'tyranny.' And in the hands of Stalker and Parker and the maker of the silk wall-panels, medium and message have changed - have transmediated-once again: Chinese torture is now allied with the delights of the bedroom. Narratives of Asian politics, reports of imperial governance, and observations of Ming judicial regimes have been reassigned, as canny producers convert Jesuit memories of corporal punishment into provocative pastiches of 'decorative' torture. Memories of pain have transmogrified into pastiches of pleasure.

\section{Producing and Consuming Early Modern Memories (Memory Sells)}

In a certain sense, images of the exotic world, which have provided the material for this cursory foray into memory and its mediations, may have lent themselves to this sort of transformation. Producers in the business of exotic geography manipulated texts and illustrations of far-away places to their advantage; while consumers, who obviously had an great appetite for this fare, had meagre means to verify these workshop interventions. Yet this may be too easy an explanation. Sources of geography (and this goes for texts as well as images) were keen to emphasise their veracity, their authors' high credentials, the eye-witness validity of their reporting, and their expressly 'memorable'-and thus implicitly reliable-portraits of the world. Geography was (and is) a science. Yet geography is also something more: it was (and is) a genre of consumable products of immense attraction. It might be understood, further, as a process of representation whereby particular memories of specific places are translated into varying and generic material forms-books, to be sure, yet also a vast array of images and objects. And these various forms indubitably shape various meanings - which brings us back to Marshall McLuhan and his prescient observation about the medium and the message. 
McLuhan, a celebrated philosopher and literary critic, is typically cited as one of the founding fathers of media studies. ${ }^{29}$ Yet it is worth recalling the influence that McLuhan also had on Madison Avenue in its 196os heyday and on the world of advertising, and it is worth noting the commercial implications of his theories of mediation. Memories surely follow many iterations - they are much handled commodities - and in their many forms, they not only take on new meanings but also obtain new values. Early modern Europe's understanding of the non-European world derived increasingly from texts and pictures built upon the actual memories of travellers and merchants who ventured abroad, expanding Europe's world of commerce and empire - this marks the great shift in the genre away from its medieval antecedents and toward a more modern geographic science. ${ }^{30}$ Yet this brief overview of early modern sources of geography-sources extracted from a traveller's direct engagements, a merchant's personal experiences, or a missionary's concrete memories-demonstrates how these reports and representations could produce something quite different. And this suggests, in turn, a broader understanding of how geography works and how memory works: how an encounter with a roadside ascetic in rural China could shape the exotic design of a ceramic punch bowl; or how an audience with a provincial viceroy could transform into a cabinet commemorating Oriental despotism; or how an eyewitness report of Ming judicial policy could produce quasi-decorative violence in a Bavarian bedroom. In all these cases, personal memories and parochial reportsaccounts that derive from the particular perspectives of an evangelizing Spanish Jesuit or an entrepreneurial Dutch merchant-could ultimately translate into generically European images of the exotic world: of Oriental despotism, heathen religion, Chinese torture, and so on. To understand these processes of transformation, one might also invoke, along with McLuhan, the sociologist of science Bruno Latour, who has studied the transition of what Latour calls local knowledge-a personal encounter or site-specific memory, for example, set in a specific context-into what Latour terms universal knowledge: a broadly understood conception of

29 Philip Marchand, Marshall McLuhan. The medium and the messenger, (rev. ed., Cambridge: The MIT Press, 1998).

30 On this moment of transition, see Joan-Pau Rubiés, Travel and ethnology in the renaissance. South India through European eyes, 1250-1625 (Cambridge: Cambridge University Press, 2000); Joan-Pau Rubiés, 'Travel writing as a genre. Facts, fictions and the invention of a scientific discourse in early modern Europe', International Journal of Travel and Travel Writing 5 (2000), 5-33; Palmira Brummett (ed.), The 'book' of travels: genre, ethnology and pilgrimage, 1250-1700 (Brill: Leiden, 2009). 
(in this case) the exotic world, as circulated in the Europe-wide sources this essay has referenced. ${ }^{31}$ In the transmediations of a Jesuit memory or a VOC embassy we can discern 'European' (rather than Spanish or Dutch) conceptions of the world. These transmediations demonstrate, in other words, how so-called counter memories are subtly and cannily produced, not uncommonly through the efforts of enterprising ateliers.

And this brings up a final point, which relates precisely to the production as well as consumption of memory. It is always more challenging for scholars of the past to analyse the consumption, rather than production, of culture: in this case, how (or even if) various material vestiges of memory-printed descriptions, engraved illustrations, painted objects, and so on -were ultimately consumed, utilised, and assimilated by early modern Europeans. They would have been consumed ('read') differently, we might assume, according to their different material forms. Yet we might be on safer ground if we consider, rather than consumption, matters of production and indeed one of the central questions posed by this volume pertaining to the authority over memory: who ultimately made and managed early modern memories? In the case of early modern sources of geography, in the moment of their enormous expansion and terrific popularity in the late-seventeenth and early-eighteenth centuries, our answer should take into account the role played by canny producers and inventive ateliers - the commercial angle and the profit motive of producers, in other words. Memory is an indubitably valuable commodity, and the profit to be extracted by rendering a 'memorable' sketch of Chinese justice into a no less memorable pastiche of titillating violence-for printed books, for household ceramics, for bedroom wall-panels-must have been considerable. As our modern mavens of memory have amply demonstrated, whether from the perspective of Madison Avenue or Hollywood or Fleet Street, memory sells. Its sales, moreover can take many, also material, forms. Whether we wish to call the redeployment of early modern memories, such as those of Johan Nieuhof and Adriano de las Cortes, a modern phenomenon or not seems moot. In all cases, the processes of these memorable transmediations and the images they produced have bequeathed to us rich and evocative forms of the early modern world, with which we still grapple to this day.

31 Bruno Latour, Science in action. How to follow scientists and engineers through society (Cambridge, Mass.: Harvard University Press, 1987), esp. 215-257. 
PART THREE

PERSONAL MEMORY 
Erika Kuijpers, Judith Pollmann, Johannes Müller, and Jasper van der Steen - 978-90-04-26125-9 Downloaded from Brill.com04/26/2023 11:57:20AM via free access 


\title{
DISTURBING MEMORIES. NARRATING EXPERIENCES AND EMOTIONS OF DISTRESSING EVENTS IN THE FRENCH WARS OF RELIGION*
}

\author{
Susan Broomhall
}

This essay asks how people memorialised distressing events in sixteenthcentury France. Exactly what constituted troubling memories for sixteenth-century people and how did they articulate their feelings about these events? Such questions have until now been mostly asked of literary and visual genres in studies of sixteenth-century violence. ${ }^{1}$ In a recent collection of essays studying trauma in Francophone literary traditions, for example, authors examined how genre inflected traumatic narratability, analysing 'the challenge of narrating trauma and the ways in which authors have made use of traditional or reconfigured generic forms in their attempts to translate traumatic experience'. ${ }^{2}$ However, if we hope to expand the range of evidence available to study memories of troubled experiences in the often extreme violence of that century, we must attend to the contexts of production of varied genres and the possibilities that they allowed for very different expressions of disturbing memories. For

\footnotetext{
* I am grateful for the insightful feedback of Erika Kuijpers. Early research for this essay was made possible through an Australian Research Council Discovery Grant.

${ }^{1}$ See, for example, Kathleen Perry Long, 'The representation of violence in the works of Theodore Agrippa d'Aubigné', in Timothy Murray and Alan K. Smith (eds.), Repossessions. Psychoanalysis and the phantasms of early modern culture (Minneapolis: University of Minnesota Press, 1998), 142-167; François Rigolot, 'French renaissance writers and the wars of religion. Ronsard, Montaigne and d'Aubigné', French Literature Series 25 (1998), 1-23; Philip Benedict, Lawrence M. Bryant and Kristen B. Neuschel, 'Graphic history. What readers knew and were taught in the Quarante tableaux of Perrissin and Tortorel', French Historical Studies 28 (2005), 175-229; Zahi Zalloua, 'From Le Printemps to Les Tragiques. Trauma, self-narrative and the metamorphosis of poetic identity in Agrippa d'Aubigné', special issue: representations of trauma in French and Francophone literature, Dalhousie French Studies 81 (2007), 29-39; Kathleen Perry Long, '“Child in the water". The spectacle of violence in Théodore Agrippa d'Aubigné', Dalhousie French Studies 81 (2007), 155-165. One exception is Mark Greengrass, 'Hidden transcripts. Secret histories and personal testimonies of religious violence in the French wars of religion', in Mark Levene and Penny Roberts (eds.), The massacre in history (New York and Oxford: Berghahn, 1999), 69-88.

2 Nicole Simek, 'Introduction', special issue. Representations of trauma in French and Francophone literature, Dalhousie French Studies 81 (2007), 1-3, there 3.
} 
personal narratives do exist that were not written by scholars or poets, and they were often presented to their readers for many different purposes. ${ }^{3}$ Narrative context (in its functions, structure, and goals) as well as the genres that these necessitated shaped the kinds of episodes of violence and distress that could be remembered and the way these memories and the emotions they generated could be expressed.

Despite repeated official injunctions to oubliance, as Kathleen Long has argued, the period during and following the wars of religion in France saw an explosion of literary, artistic and historical works which attempted to make sense of the period's violent events. ${ }^{4}$ At some level, all written accounts are acts of memorialisation, where decisions are made about what to include and what to leave out. Indeed, Susan J. Brison has critiqued the tendency in trauma analyses to distinguish between

traumatic memories (viewed as bodily, fragmented, sensory, intrusive, recurrent, uncontrollable) and narrative memories (viewed as linguistic, more coherent, more under control). Traumatic memory, like narrative memory, is articulated, selective, even malleable, in spite of the fact that the framing of such memory may not be under the survivor's conscious control. ${ }^{5}$

By their nature, narratives 'have an orientation, a temporal sequence of actions, a complication, an evaluation, and a resolution', ${ }^{6}$ although these facets may be more or less explicit in each text. With this in mind, I have tried to scan widely across different document types to be alert to records of disturbing memories and to see what opportunities particular sources provided for different narratives and kinds of violence and sentiments to be recalled and recorded. I thus approach the narratives examined here as not simply presented in, but also as produced through, their particular form. There were also different audiences, times, and socio-historical contexts that allowed for different stories to be heard by particular

3 On the purposes of such narratives, see Susan Broomhall, 'Reasons and identities to remember. Composing personal accounts of religious violence in sixteenth-century France', French History 27 (2013), 1-20.

4 Long, '"Child in the water"', 160.

5 Susan J. Brison, Aftermath. Violence and the re-making of a self (Princeton: Princeton University Press, 2002), 31.

${ }^{6}$ Kathleen Slobin, 'Repairing broken rules. Care-seeking narratives for menstrual problems in rural Mali', Medical Anthropology Quarterly 12.3 (1998), 363-383, there 367. Slobin borrows here from the work of William Labov, 'Speech actions and reactions in personal narrative', in Deborah Tannen (ed.), Analyzing discourse. Text and talk (Washington: Georgetown University Press, 1982), 219-247, and William Labov and Joshua Waletsky, 'Narrative analysis, oral versions of personal experience', in June Helm (ed.), Essays on the verbal and visual arts (Seattle: University of Washington Press, 1967), 12-44. 
narrators, ${ }^{7}$ for the nature of distress, emotional expression, and access to written memory-making were all socially coded and determined. ${ }^{8}$ Constructions and presentations of identity permitted certain narratives to be expressed and shaped how they were articulated and to whom as well as in what contexts and genres they were produced, and for what purposes.

When analysing how feelings about violence were narrated, it is impossible to distinguish those experienced at the time from those remembered or perhaps created in the act of later reflection. While the rhetoric, techniques and omissions of mémoires as a genre have received detailed attention from historians and literary scholars, ${ }^{9}$ scholarly investigation of the emotional articulation of violence in such records is more limited. For the sixteenth century, analyses have focussed particularly on confessional distinctions (and limitations) regarding affective expression. Costas Gaganakis, for example, has argued that Calvinism's 'strict emotional regime ... sought to impose strong emotional management tools, based on the bipolar construction of sin and redemption, at the expense of allowing scope for self-exploration and navigation on the part of members of the community'. ${ }^{10}$ Others have considered the possibility of repression or incapacity to articulate the violent events experienced. Mark Greengrass

7 As Diane Bjorklund argues, autobiographical narratives are produced with assumptions about their readerships which affect how and which events are recounted and the self-appropriate to that audience. See Diane Bjorklund, Interpreting the self. Two hundred years of American autobiography (Chicago: The University of Chicago Press, 1998), 10, 17.

8 In this respect, some of the recent psychological literature that examines gender analysis of distress is rather unhelpful because the social coding of modern gender emotive expression does not match that of early modern records. Useful studies, however, for considering gender differences in the production of trauma memory (although the outcomes are clearly different from those studied here) have been Myrna Goldberg, 'Memoirs of Auschwitz survivors. The burden of gender', in Carol Rittner and John K. Roth (eds.), Different voices. Women and the Holocaust (New York: Paragon House, 1993), 327-339 and Sara Reva Horowitz, 'Women in Holocaust literature. Engendering trauma memory', in Dalia Ofer and Lenore J. Weitzman (eds.) Women in the Holocaust (New Haven: Yale University Press, 1998), 364-377.

9 See, for example, the significant Francophone work in this area. Noémi Hepp and Jacques Hennequin (eds.), Les valeurs chez les mémorialistes français du XVIIe siècle avant la Fronde (Paris: Klincksieck, 1979); Madeleine Bertaud and André Labertit (eds.), De l'Estoile à Saint-Simon. Recherche sur la culture des mémorialistes au temps des trois premiers rois Bourbon (Paris: Klincksieck, 1993); Madeleine Bertaud and François-Xavier Cuche (eds.), Le genre des mémoires. Essai de définition (Paris: Klincksieck, 1995); Nadine Kuperty-Tsur, Se dire à la renaissance. Les mémoires au XVI ${ }^{e}$ siècle (Paris: J. Vrin, 1997); Jacques Berchtold and Marie-Madeleine Fragonard (eds.), La mémoire des guerres de religion. La concurrence des genres historiques XVI ${ }^{-}-X V I I I^{e}$ siècles (Genève: Droz, 2007).

10 Costas Gaganakis, 'Stairway to heaven. Calvinist grief and redemption in the French Wars of Religion', Historein 8 (2008), 105. 
suggests, for instance, that the absence of elaborated affective expression by eye-witness narrators of the Saint Bartholomew's Massacre might result from such eye-witnesses having 'no means of explaining to others, in language which could possibly convey it, the full emotional intensity of what they had experienced'.11

Do such findings take sufficient account, however, of contemporary forms of affective expression and conceptualisation? In the sections to follow I explore different kinds of accounts presenting disturbing memories of the sixteenth century's violent events. In doing so, I ask: can we identify words, phrasing, and structures that reflect early modern narrators' methods of engaging with those memories? How did emotions function to enable articulation of a distressing event, and where and when was emotional vocabulary employed in its recall? Who could use certain emotional descriptions and vocabularies in order to express particular kinds of feelings about violence that narrators remembered experiencing?

\section{Affective Memories}

Distress about the religious violence and upheavals was memorialised in personal accounts by many narrators for a wide variety of audiences and contexts, as we shall see. For some, explicit emotional language was critical to narrating disturbing events. This appears particularly common among Catholic religious, whose chronicles documented in dramatic and highly-charged emotive language the destruction of religious sites and objects, the dispersal of the community to safer properties, and the risk of sexual violence, as well as troop movements, battles and victories of the faithful. ${ }^{12}$

However, the same mode of expression can also be located in accounts produced by Catholic lay faithful. The chronicle of Etienne Médicis, a merchant and bourgeois citizen of Le Puy, purported to compile a history of his town for the edification of its magistrates, consuls and citizens. While a series of the events he detailed preceded his birth, the latter portion of the text recorded his eye-witness experiences of Huguenot attacks on the

11 Greengrass, 'Hidden transcripts', 8o.

12 See discussion of these in Broomhall, 'Reasons and identities to remember'; Susan Broomhall, 'Disorder in the natural world. The perspectives of a sixteenth-century provincial convent', in Jennifer Spinks and Dagmar Eichberger (eds.) Religion, the supernatural and visual culture in early modern Europe (Leiden: Brill, 2014, forthcoming). 
town. Médicis built up a catalogue of violence to sacred religious statues and images: how Huguenots had broken the arms and legs off crucifixes in the cemetery of Broueil and how in 1554 they had in the dead of night destroyed the image of St Martin from the conventual church of Saint Laurens. On 10 March 1561, some people 'put their polluted hands quite viciously on the image of the glorious Mary Magdalene'. ${ }^{13}$ Then Médicis described how Huguenots in Le Puy had desecrated the holy and miraculous image of Nôtre-Dame in word and deed:

calling her idol, chunk of wood, blackened thing and her images made on paper arse-wipes, and they were said to put the good Lady's rosary on their dogs, and other varied and vile, outrageous, disgraceful, atrocious insults that they proffered against this holy image [...] I am sad and horrified to write them down! ${ }^{14}$

This violence was not (as yet) violence to Le Puy's population but damage to long-held rituals and customs of the town. In the following year, Médicis would report how, for the procession of May 1562, the bishop had to be accompanied by a large number of arquebusiers: 'a monstruous and pitiful thing to see'. ${ }^{15}$ These observations were filled, for Médicis, with grief, sadness and sorrow. The damage to cherished icons was, for Catholic faithful, 'a difficult sight for the people to see'. ${ }^{16}$ As Médicis neared the end of his chronicle, he feared for the future: 'things have fallen into such disorder that, if God does not extend us his grace, the Church and the temporal world, all will undoubtedly fall into extreme desolation'. ${ }^{17}$

This affective language was shared by lay and religious Catholics alike, in an emotional regime that was also that of the anticipated readership of such works. One might assume that these readers would already be inclined to sympathise with losses suffered in violent attacks, yet this sympathy did not alter the strong emotional language of such narratives. Instead, these narrators shared an affective rhetoric of suffering and lament for their individual losses, which marked and bound them as members of their faith. Indeed, ostentatious grief set such narratives apart from the Calvinist model of controlled emotional expression and could

13 Augustin Chassaing (ed.), Le livre de Podio, ou chroniques d'Etienne Médicis, 2 vols., (Le Puy-en-Velay: M.-P. Marchessou, 1869), vol. 1, 511-512.

14 Ibid., 512.

15 Ibid., 528 .

16 Ibid., 504 .

17 Ibid., 504 . 
thus be read as a particular act of devotion. ${ }^{18}$ For these narrators, explicit emotional terms enabled and articulated grief, sorrow and loss, but this was not the case for all those who recounted distressing experiences.

\section{Indirect Autobiography. Emotions at a Distance}

For another group of authors, violence was narrated within mémoires that documented the participation of elite men in the political and military actions of their day. ${ }^{19}$ A series of such mémoires eschewed first-person narrative, adopting an authorial voice in either the second, or more commonly, third person. Simone Bertière has suggested that this style distinguished such individuals as aristocrats, ostensibly with secretaries to undertake the business of writing their lives for posterity: 'To great lords the sword, to their subordinates the pen'. ${ }^{20}$ The impersonal voice of the fictive narrator, she observes, suited facts and events but was less appropriate for passages of reflection, anecdote or piquant details. ${ }^{21}$ At first glance, such accounts would seem an unlikely source for feelings about the violence which these authors had experienced first-hand.

Yet some authors did describe their emotions upon witnessing the violence of such events as the Saint Bartholomew's Massacre. Interestingly, accounts by both Catholic and Calvinist male narrators emphasised the need to repress and control the emotions they felt at the time. JacquesAuguste de Thou, for example, remembered the horrific sight of mutilated bodies in the street on 'this terrible day'.

He could not look without horror at the bodies of Jérôme Groslot, bailli of Orléans, and of Calixte Garrault, that they dragged to the river by the closest street. He was obliged to witness these horrible things without daring to shed a tear, he whose natural tenderness did not permit him to see the death of an innocent animal without emotion. The pain that this caused him obliged him to go out no more, for fear of encountering similar sights. ${ }^{22}$

18 See also chapter 14 by Andreas Bähr.

19 Or sometimes in defence of their personal character, distinct from the political events in which they were involved.

20 Simone Bertière, 'Le recul de quelques mémorialistes devant l'usage de la première personne. Réalité de la rédaction et artifices de l'expression', in Hepp and Hennequin (eds.), Les valeurs chez les mémorialistes français, 65-88, there 66-67.

21 Ibid., 69.

22 'Mémoires de Jacques-Auguste de Thou, depuis 1553 jusqu'en 16o1', ed. Claude-Bernard Petitot, in Collection des mémoires rélatifs à l'histoire de France, Series I, $5^{2}$ vols. (Paris: Foucault, 1819-29), vol. 37 (1823), 232. 
De Thou's muted, if not openly jubilant, response to the death of confessional 'others' was necessary at the time, marking out his membership among the Catholic faithful. However, his mémoires revealed a secondary emotional reaction, whether truly felt at the time or developed in retrospect: one of horror of violent cruelty and indignity to the corpses of fellow men.

Calvinist Jacques Nompar de Caumont provided a similar third-person narration of his experiences during the massacre in Paris. His mémoires provided a detailed account of seeing his father and elder brother killed before his eyes. ${ }^{23}$ Caumont was with them both when they were discovered in hiding and pulled onto the streets, taken to the rue des PetitsChamps where soldiers attacked the group, fatally stabbing his father and elder brother. Jacques, covered in blood but unhurt, fell with them, lying motionless in the street as they were stripped of their goods and clothing. There he remained, naked, for hours amongst the dying and dead bodies of his family, a time he recalled as one of deep emotional anguish:

If his body had not been hit, his mind was by contrast cruelly agitated, for he heard his father had remained a long time dying and had heard him sob several times. What anguish and what perplexity to find himself between a father and brother cruelly killed and whose sobs were like stabs of a dagger that pierced his heart! ${ }^{24}$

This scene remained an unquestionably emotional memory which Caumont - at a distance of many years — detailed over several pages of his work, recording the last words and actions of his father and brother as well as those of their tormenters and killers.

Neither author dwelt at length upon his evidently strong feelings about what he witnessed, but neither did he repress the emotions that these events had generated for him at the time and since. It is indeed possible that the device of the fictive narrator may have enabled such authors to articulate feelings which were more difficult to express in a first-person authorial voice. Memories of violence and emotion narrated in indirect autobiographies characterised their authors not as Catholic or Calvinist but rather as learned and aristocratic men of the political and military elite.

23 Mémoires authentiques de Jacques Nompar de Caumont, duc de La Force, ed. Le Marquis de La Grange, 4 vols. (Paris: Charpentier, 1843). Also discussed by Greengrass, 'Hidden transcripts', 78.

24 Mémoires authentiques de Jacques Nompar de Caumont, vol. 1, 18. 


\section{Violence Seen and Heard. Displaced Emotions}

For some narrators, their own feelings in times of violence were not foregrounded in their memories of fighting and violence. Instead, their narratives emphasised how they had heard violent episodes and observed the emotions of others in these acts. ${ }^{25}$

Charlotte Arbaleste de la Borde and her second husband Philippe Duplessis-Mornay were leading Calvinist political advocates. ${ }^{26}$ In 1584 Arbaleste began to write a memoir of her husband as an exemplary life for her son, to which she continued adding until her son's death in $1605 .{ }^{27}$ The memoir concentrated largely on public and historical concerns and in particular on Duplessis-Mornay's military, diplomatic, and political accomplishments. Yet her memories, some of highly distressing events, formed an additional second narrative throughout the text. Arbaleste recounted both her own and her future husband's escape from Paris during the 1572 massacre, hiding in Paris for days, moving from house to house as the trouble spread, before she was finally able to flee the city. Interestingly, how she felt about these events was addressed indirectly; what Arbaleste described were the emotions of those around her-her kitchen maid who first told her the news was 'greatly frightened', while in the street, Arbaleste could see 'everything in such a commotion'. Later, from one hiding place in an attic, she recalled hearing the 'strange cries of men, women and children that they massacred in the streets'. ${ }^{28}$ Sound was a sense that could not be shut out from the mind.

Moreover, Arbaleste allowed others to assess her own emotional state in her text, reporting how the two soldiers who stopped her as she tried to escape the city in a boat suspected her of being a Huguenot because

25 Greengrass ('Hidden transcripts', 76) also notes this feature in the mémoires of Maximilian de Béthune. Attention to date has generally been given to visualising distress and its impact on viewers and readers in printed and literary illustrations of violence. Long, 'The Representation of Violence'; Benedict, Bryant, and Neuschel, 'Graphic history'; Philip Benedict, Graphic history. The wars, massacres and troubles of Tortorel and Perrissin (Geneva: Droz, 2007).

${ }^{26}$ See also Catharine Randall, 'Shouting down Abraham. How sixteenth-century Huguenot women found their voice', Renaissance Quarterly $5^{\circ}$ (1997), 411-442. See Susan Broomhall and Colette H. Winn, 'La représentation de soi dans les mémoires féminins du début de l'époque moderne', Tangence 78 (2005), 11-35.

27 Susan Broomhall and Colette H. Winn, 'Femme, écriture, foi. Les mémoires de Madame Duplessis-Mornay', Albineana 18 (2007), 587-604; and Les Mémoires de Madame de Mornay, ed. Nadine Kuperty-Tsur (Paris: Honoré Champion, 2010).

28 Ibid., 108. 
she appeared so frightened she could hardly speak. ${ }^{29}$ The emotions that Arbaleste expressed in such moments of violence were mostly ones she attached to those around her, rather than to herself. This approach set an affective tone - of fear and terror — for her own experiences, but Arbaleste did not speak at length of her feelings about them. Such an account (like that of Médicis above) reminds us that explicit emotional language was by no means the exclusive preserve of women but perhaps more closely linked to expressions of faith.

Indeed, on the rare occasion when Arbaleste chose to remember her own emotions in her own words, it was rhetorically purposeful. She remembered experiencing one moment of absolute fear for her daughter in which she felt 'such perplexity and almost despair' that she nearly decided to let herself fall to her death rather than place herself in the hands of the enemy or see her own daughter slaughtered. ${ }^{30}$ This however was a self-criticism the recall of which had a pedagogical intent; despair was a sin. Arbaleste had almost, momentarily, lost faith in God's plan for her, whatever it might be.

\section{Detailing Violence. Affective Values}

As with the accounts above, many narratives of violent events described experiences and destruction in precise detail. Some recounted stories of violent destruction to bodies and properties in the hopes of financial compensation or justice for their losses. ${ }^{31}$ These details implied rather than rendered explicit affective states. In such accounts, affective intensity was rendered in at least two ways: through detailed and cumulative descriptions of the loss, not of people, but of things, and through the careful elaboration of the high financial value of the things that had been destroyed by violence.

After religious violence, convent communities were among those which resorted to legal intervention to secure restitution of their goods. These

29 Ibid., 109.

30 Ibid., 109 .

31 Penny Roberts has observed that Protestant noblewomen and urban widows could petition successfully on their own behalf. These requests, she argues, were sometimes easier to respond to than those of a whole community. Roberts, Huguenot petitioning during the wars of religion', in Raymond A. Mentzer and Andrew Spicer (eds.), Society and culture in the Huguenot world, 1559-1685, (Cambridge: Cambridge University Press, 2002), 74-75. 
claims were made in terms that emphasised the value of the goods and their meaning to their communities, but grief at their loss and distress at the treatment of sacred objects and spaces in the hands of non-believers were implied rather than foregrounded. After the 1562 religious violence in Lyon, the Benedictine community of Saint-Pierre-des-Nonnains recounted how the community had incurred 'great and inestimable losses, as much of sacred as of profane goods and movable as well as immovable, by the ruin and demolition of their churches and houses done by those who call themselves of the reformed church'. ${ }^{32}$ The sisters particularly lamented the role played by Claude Gosset who had been installed by the Huguenots in the complex with his wife and family and who had 'stolen, pillaged and removed the most beautiful and precious of their sacred and profane goods' ${ }^{33}$ These and other grievances, including the destruction of a wall so that their site communicated directly with the street and the building of a Huguenot temple on one of their lands close by, had tainted the sacred space of their convent site. ${ }^{34}$ Their memories and ongoing experiences of violence and loss spoke of the physical, spiritual and emotional damage of the 'greatly inconvenienced' nuns, but the legal context in which their narrative was presented shifted the focus to precise values and itemised lists, rather than feelings. This approach, they felt, was most likely to achieve what they needed: repairs to their properties and the return of the goods that had been stolen.

For another narrator, it was the detailed and cumulative experience of slow starvation among the Parisian population during the siege of 1590 which stood for the horrors of famine and war. In that year, the staunchly Catholic city was subjected to a four-month siege by Henry of Navarre's forces. Surrounding towns had been cleared by Henry's troops, increasing the population of Paris with few resources to sustain them. Filippo Pigafetta, a zealous Catholic in the employ of the papal legate and eyewitness to the siege, recalled in gruesome and precise detail the depths to which the city's living conditions sunk but also carefully recorded the measures that the city governors took to alleviate the suffering and to spread meagre resources as far as they could. As stocks dwindled, the poor were provided a broth of water through which oat flour had been

\footnotetext{
32 Archives départementales du Rhone, $27 \mathrm{H}_{5} 6$.

33 Ibid.

34 Ibid.
} 
strained with a pinch of salt. ${ }^{35}$ Pigafetta recounted that bread concoctions were carefully measured and made with nut meal, then candle fat, any non-poisonous herbs to be found, and finally were rumoured to be composed of powdered animal bones. Vine leaves still left in the city's gardens were consumed and all the city's horses, donkeys and mules were used as meat while others ate the city's remaining dogs, cats, rats and mice seasoned with vinegar and herbs, and boiled the animals' skins. ${ }^{36}$ Pigafetta estimated that 5000 had died in the siege, not counting infants; other chroniclers suggested that the deaths numbered between 12,000 and 30,000. ${ }^{37}$ This account recorded the full grisly misery of famine for a Catholic Italian audience - the memories of this distressing event were articulated through quantitative data: numbers dead, resources used, and alms distributed. It teased out in fine detail the suffering especially of the poor Catholic faithful of the city at the hands of 'the Navarrois' (later Henry IV) but emphasised that they accepted the torture of hunger for their faith.

\section{In the Margins. Emotions at the Edge}

For Arbaleste, a large digression to recount her own experience of the Saint Bartholomew's Massacre is suggestive of the event's significance in her identity as a Calvinist survivor. ${ }^{38}$ For others too, digressions only marginally related to the purpose of a narrative could reflect the importance of disturbing memories that needed to be told. Rarely did these narratives extend beyond the factual and financial, but their very existence in accounts designed for other purposes is suggestive of their strong affective meaning for individuals.

The 'articles de souvenance' recorded by Jean Robert Le Jeune and his two sons, both named François, from the town of Couchey in the Coted'Or, cover the period from 1573 to 1668 . The events they listed for memorialisation included unusual climate phenomena and astrological signs, and their repercussions for the price of wine or grain. Theirs was not an

35 'Histoire du siège de Paris sous Henri IV en 1590, d'après un manuscrit nouvellement découvert', ed. A. Dufour, Mémoires de la Société de l'Histoire de Paris et de l'Ile-de-France 7 (1880), 206.

36 Ibid., 216-217.

37 Ibid., 77.

38 See, similarly, the account of Renée Burlamacchi in Les femmes et l'histoire familiale (XVI ${ }^{e}-X V I I^{e}$ siècle). Renée Burlamacchi, descrittione della vita e Morte del Signor Michele Burlamachi (1623); Jeanne du Laurens, genealogie de Messieurs du Laurens (1631), eds. Susan Broomhall and Colette H. Winn (Paris: Honoré Champion, 2008). 
account of the elite or of urban citizens but of peasants interested in rural life and events which had a particular bearing on agriculture. Among these events was the destruction caused by Calvinist attacks in their region, such as in 1569, when 'the Huguenots came into this region of Dijon where they did great damage to the poor people and burned houses in several villages, and this was in the month of May $1569{ }^{\prime} \cdot{ }^{39}$ Likewise, in 1576:

the $15^{\text {th }}$ of the month of January, the huguenots came into the region where they carried out great destruction, and came to fight at Nuys where they remained six or seven days, and they came inside and killed the people such as the wine growers and tradespeople, and held the richest people for ransom, and set fire to the town which they left half burned down, and burned many houses and villages that they passed. ${ }^{40}$

These were not entries which dwelt on the emotional impact of these events for those who experienced them, but their very recall in texts speaks to their meaning as the key events in a lifetime that deserved to be recorded for future generations.

Other memories of distress found voice in records that seemed primarily concerned with documenting professional status and achievement. This was the case for Louise Bourgeois who, in the second volume of her published text on midwifery Observations diverses (1617), reflected on her painful memories of living in the suburbs of Paris during the 1590 siege as part of an explanation for why she, the wife of a professional surgeon, had become a midwife. She recalled how her family had been living in SaintGermain when her neighbour had word about the impending approach of soldiers from her husband, who advised his wife to retire with their goods within the walls of Paris. Bourgeois, whose husband was away with the army, did likewise, along with her mother and three children, leaving their properties in the hands of an elderly woman. 'We took only a little furniture with us, because it was hard to get through the Saint-Germain gate without great difficulty'. She described how the King's troops, then the Lasquenets, destroyed the houses her father had built less than five years previously, along with her own financial security and social status:

That night, the suburbs were taken, and all of the best things were pillaged. When the King's men were leaving the suburbs, the city sent out a garrison

39 Deux livres de raison Bourguignons. Le livre de Dominique de Cuny. Chronique dijonnaise du temps de la Ligue, et le livre de la famille Robert. Notes sur le village de Couchey, ed. C. Oursel (Dijon: Libraire J. Nourry, 1908), 108.

40 Ibid., 109. 
of lance-knights, who reduced everything to rubble. Not a stick of wood remained, although most cellars had been full of them. When the lanceknights had left, fifteen thousand livres' worth of houses were destroyed; my father had had them built on the trench at the Bussy Gate, and they had been there for only five years. ${ }^{41}$

Bourgeois then recounted how her family was forced to sell the goods piece by piece to maintain themselves in the city, 'We had no possessions except what little we had brought with us, which we lived off of by selling it day by day, bit by bit... I endured the entire duration of the troubles in this way, until the last month or so'. It was after the family returned from Tours, with a pressing need to generate some revenue, that she was convinced by her own midwife to begin training towards that profession. ${ }^{42}$ Bourgeois' extended discussion of the episode and the details regarding the devastation of the family heritage seem to bear witness to its deep significance for her (echoing the memories and narratives of the paupers discussed above). Her gripping narrative employed a rich vocabulary that made clear her feelings of loss and itemised it in financial terms. However it was also critical to her future professional choices and appeared as such in her chapter entitled: 'How I learned the art of midwifery'.

Such added information highlights how some generic contexts could allow distressing memories to be heard and suggests that authors used their narratives to make sense of past and present identities that were the consequence of traumatic events.

\section{Conclusions}

Attempts to record distressing and violent experiences can be found in a wide range of documents. Authors were often writing at a distance of many years after these events, yet their accounts were no less detailed, no less able to supply precise conversations, names, voices and experiences about what had befallen them or those people and objects that they cherished. Clearly differing contexts and genres shaped their opportunity for expression, the narrative which the memory could participate in, and the kinds of identities that could be associated with it. In turn, sense of

41 Louise Bourgeois, Diverse observations (Paris, 1626), ed. Alison Klairmont Lingo, transl. Stephanie O'Hara, (Toronto: Centre for Reformation and Renaissance Studies Publications, forthcoming).

42 Ibid. 
self shaped where and how people might express distressing events. Many had memories of the violence of the sixteenth century, but few had a wide range of opportunities for recording their specific experiences.

With these provisos, violent events that were deemed worthy of record ranged from murder, attempted rape, and massacres to witnessing the desecration of religious objects in word or deed. Penny Roberts has observed that endemic and continual forms of violence were present in everyday society, arguing that Huguenots suffered intimidation and verbal abuse as well as physical violence. As she points out, it must have been difficult for those living through such situations to know whether this was the limit of their harassment or whether persecution might escalate into something far worse. ${ }^{43}$ Many memories of experiences during the violent wars of religion suggested just such a climate of fear (their own and that of those around them) but also a need to control the expression and visibility of feelings during moments of crisis, for practical reasons as well as in keeping with spiritual beliefs.

On the whole, distressing events were not usually articulated through explicitly emotional vocabulary. Yet narrators negotiated ways within their genres and contexts to document violent experiences that they found disturbing, painful, sad and frightening. Some recollections were visualised, while others remembered cries, speeches and sounds that they could not shut out-experiences that authors felt needed to be heard and seen by their readers. Others found expression of their experiences through itemising things lost or emphasising their financial value. A few ascribed emotions to those around them, suggesting how others felt in such circumstances in ways which implied, but eschewed focus on, their own affective states.

These techniques of emotional expression were consistent with the affective language of their era, gender, status, learning and faith. Scholars of emotion have debated whether texts which do not manifestly speak of feelings should be included for analysis in studies of emotion; but for non-literary narratives of distressing events, this may well be the majority (depending on how manifest expression of feeling is determined). ${ }^{44}$ Yet,

43 Penny Roberts, 'Peace, ritual, and sexual violence during the Religious Wars', in Graeme Murdock, Penny Roberts and Andrew Spicer (eds), Ritual and Violence. Natalie Zemon Davis and Early Modern France, Past and Present Supplements 7 (Oxford; Oxford University Press, 2012), 75-99, there 75-76.

44 Benno Gammerl, 'Emotional styles-communities and spaces' H-Soz-u-Kult. Consulted on 16 September, 2010, from http://hsozkult.geschichte.hu-berlin.de/tagungsberichte/ id $=3275$. 
although recognisable and certainly lengthy affective content may seem less visible to modern readers, emotions were at the very heart of such accounts and of the wars of religion themselves. These evocations of distress experienced, seen, heard and compiled may have been tragic and painful for their authors, but, as we have seen, their modes of expression were often ways to emphasise faith or confessional politics. Moreover, for both sides, these disturbing experiences served a key purpose: they were testament to the glory of suffering for Christ or evidence of His mercy. 
Erika Kuijpers, Judith Pollmann, Johannes Müller, and Jasper van der Steen - 978-90-04-26125-9 Downloaded from Brill.com04/26/2023 11:57:20AM via free access 


\title{
REMEMBERING FEAR. THE FEAR OF VIOLENCE AND THE VIOLENCE OF FEAR IN SEVENTEENTH-CENTURY WAR MEMORIES
}

\author{
Andreas Bähr
}

In the summer of 1634 murdering and plundering Swedish troops threatened the Catholic Dominican convent Zum Heiligen Grab near Bamberg. On 19 August, however, as we learn from the nun Maria Anna Junius, 'the Swedish military that had been deployed across this area moved on in great haste and fear to Schweinfurt'. The chronicler was amazed by this sudden decampment, 'since at that time, not a single one of the Emperor's soldiers was around'. She could explain these happenings only as an act of God: 'I believe, our Lord has struck them with fear and driven them away'. Let us now move to Vienna, 1683. For two months, the city had been 'frightened' by the 'Turks'. ${ }^{2}$ Yet contemporary observers recount how, when the allied relief troops arrived at Vienna, the Ottoman forces, who had been so terrifying before, suddenly took fright and fled from their positions. Again, the victors felt 'astonishment'; the enemy had taken flight even though its military situation had been far from precarious. Authors could explain this behaviour only as the result of divine intervention. According to numerous broadsheets and eyewitness accounts, God had 'put a hare into the Turks' breast' and fear into their heart; He had 'struck' them with a 'blindness' that not only prevented people from recognising

\footnotetext{
1 Maria Anna Junius, 'Verzeignuß', published in 'Bamberg im Schweden-Kriege', ed. Friedrich Karl Hümmer, Bericht des Historischen Vereins für die Pflege der Geschichte des ehemaligen Fürstbistums Bamberg $5^{2}$ (1890), 1-168, and 53 (1891), 169-230, there 207 [my translation]. On Junius cf. Geoff Mortimer, Eyewitness accounts of the Thirty Years War 1618-48 (Basingstoke, Hampshire and New York: Palgrave, 2002), 97-111; Charlotte Woodford, Nuns as historians in early modern Germany (Oxford: Clarendon Press, 2002), esp. 117-143; Eva Kormann, Ich, Welt und Gott. Autobiographik im 17. Jahrhundert, Selbstzeugnisse der Neuzeit 13 (Cologne, Weimar and Vienna: Böhlau, 2004), chpt. II.B.1.

${ }^{2}$ For references see n. 13 .
} 
God but also blinded them to their own advantage. ${ }^{3}$ According to natural philosophers, such blindness resulted from fear, anxiety and terror. By striking them with blindness, God had thus also struck them with fear.

These 'scourges' of fear must not be regarded as mere metaphors. In the seventeenth century, fear and anxiety were perceived to be physically violent; that is, they were 'affects' in the historical sense of the word: they 'affected' the body and caused it to move- both externally as well as internally. The fear of violence sent by God might result not only in flight but also in deadly illness or sudden death. It was not until the late eighteenth century that we can observe the epistemological shift that remains influential today. In Enlightenment thought, 'affects' were transformed into 'feelings' and confined within the closed and inaccessible inner space of the person. ${ }^{4}$ We can find significant differences between spatial concepts of fear and anxiety in the early modern period and their psychological conceptualisations since the late eighteenth century. Fear could be perceived as physically powerful and violent because the inner space of the person did not qualitatively differ from external space.

In the Thirty Years War and the wars against the 'Turks', autobiographers, diarists and chroniclers recalled not only the physical violence they

3 Johann Peter von Vaelckeren, Wienn von Türcken belägert/von Christen entsezt ... (Linz, 1684), 92; Summarische Relation/ Was sich in währender Belägerung der Stadt Wien inund ausser deroselben zwischen dem Feind und Belägerten von Tag zu Tag zugetragen.... (Nuremberg, s.a.), 12; Eberhard Werner Happel, Der Ungarische Kriegs-Roman, Oder Außführliche Beschreibung/Deß jüngsten Türcken-Kriegs ... (Ulm, 1685), 812.

4 On the concept of 'affect' see e.g. Justus Georg Schottelius, Ethica. Die Sittenkunst oder Wollebenskunst, ed. Jörg Jochen Berns (reprint of the Wolfenbüttel edition, 1669; Bern and Munich: Francke, 1980), 109. 'Passion' and, in rare cases, 'emotion' (literally meaning the bodily 'motion' of vital spirits, humours, the senses, and the soul) could be used synonymously with 'affect'. See 'Affectus', in Johann Heinrich Zedler (ed.), Grosses vollständiges Universal Lexicon aller Wissenschafften und Künste (Halle an der Saale and Leipzig, 17321754), vol. 1, col. 718; 'Emotion', in Jacob and Wilhelm Grimm (eds.), Deutsches Wörterbuch. Neubearbeitung (Leipzig and Stuttgart: Hirzel, 1983-), vol. 7, col. 1253; 'Passion', in Ephraim Chambers (ed.), Cyclopcedia: or, an universal dictionary of arts and sciences ... (London, 1728), vol. 2, 759-762, there 760-761; Michel de Montaigne, Les Essais, ed. Jean Balsamo, Bibliothèque de la Pléiade 14 (Paris: Gallimard, 2007), bk. 2, chpt. 11, 445, 447; Jacques Chaillou, Traité du mouvement des humeurs, dans les plus ordinaires émotions des hommes (Paris, 1680). Cf. Dominik Perler, Transformationen der Gefühle. Philosophische Emotionstheorien 1270-1650 (Frankfurt am Main: Fischer, 2011), 24; Catherine Newmark, PassionAffekt-Gefühl. Philosophische Theorien der Emotionen zwischen Aristoteles und Kant, Paradeigmata 29 (Hamburg: Meiner, 2008), 9-10; Barbara H. Rosenwein, 'Emotion Words', in Piroska Nagy, Damien Boquet (eds.), Le sujet des émotions au Moyen Âge (Paris: Beauchesne, 2008), 93-106. On the modern concepts of 'feeling' (Gefühl) and 'emotion' cf. Ute Frevert, 'Gefühle definieren. Begriffe und Debatten aus drei Jahrhunderten', in Ute Frevert et al., Gefühlswissen. Eine lexikalische Spurensuche in der Moderne (Frankfurt am Main, New York: Campus, 2011), 9-39, there 24-31. On the spatiality of 'feeling' cf. Monique Scheer, 'Topografien des Gefühls', in Frevert, Gefühlswissen, 41-64. 
had suffered but first and foremost the fear of this violence. I will argue that in order to understand the historical function of these war memories, we need to historicise the language of fear and anxiety as well as concepts of selfhood and the person. First, that involves analysing seventeenthcentury notions of the nature, causes and effects of fear and its religious and moral associations. Secondly, we have to examine why people wrote about fear. It is not my objective to establish whether authors were 'actually' experiencing fear and anxiety or succeeded in 'coping' psychologically with emotional distress (such as historians of mentalities do when applying modern concepts of feeling). Rather, I analyse the functions of describing these affects. ${ }^{5}$ Those who wrote about fear and anxiety, be it their own fear or that of others, positioned themselves as fearless and Godfearing believers. They recalled the violent fear of a violence past in order to prove that, in the here and now, they had overcome their fear as well as to exemplify the conditions for combating fear effectively. In doing so, they not only remembered destructive fears from the past but also urged their readers to experience the right fear in the future: that is, the fear of God. Time and again, authors of seventeenth-century German war memoirs underlined the 'indescribability' and 'ineffability' of what they had suffered. In doing so, however, they did not remain silent but paradoxically were moved to describe their earlier experiences. They considered it necessary to recount in detail their sufferings. In providential thought, it was only through remembering fear that life could be lived without fear.

In the seventeenth century, fear of violence appeared to many to be more terrifying than the violence that was feared. ${ }^{6}$ How can this phenomenon

5 For a psychohistorical approach towards the history of early modern fear and anxiety see in particular Jean Delumeau, La peur en Occident (XIV ${ }^{e}-X V I I I{ }^{e}$ siècles). Une cité assiégée (Paris: Fayard, 1978) and his Sin and Fear. The Emergence of a Western Guilt Culture, 13th18th Centuries (1983, New York: St. Martin's Press, 1990). Recent research offers criticism of Delumeau's empirical results but not of his psychological categories: William G. Naphy and Penny Roberts (eds.), Fear in early modern society (Manchester and New York: Manchester University Press, 1997); Anne Scott and Cynthia Kosso (eds.), Fear and its representations in the Middle Ages and Renaissance, Arizona Studies in the Middle Ages and the Renaissance 6 (Turnhout: Brepols, 2002); on the nineteenth and twentieth centuries cf. Joanna Bourke, Fear. A cultural history (London: Virago, 2005).

${ }^{6}$ Johann Heinrich Alsted, Encyclopcedia Septem tomis distincta (Herborn, 1630), 2369, tacitly quoting from Laelius Peregrinus, De noscendis et emendandis animi affectionibvs [1603] (Leipzig, 1714), 190-191; Schottelius, Ethica, 224; Christoph Lehmann, Florilegium Politicum. Politischer Blumen Garten, ed. Wolfgang Mieder, Nachdrucke deutscher Literatur 
be explained? As many authors told their readers, fear and anxiety were able to affect not only the imagination but also the physical world. A timorous and fearful imagination seemed capable on its own of bringing about the very things and events it dreaded. Physicians in particular gave many examples of such occurrences. Almost every tract on epidemics pointed out that to timorously imagine the plague might cause the malady. When trying to explain this mechanism, physiologists referred to humours and vital spirits, firstly, to an oppression of the heart, and secondly, to the power of imagination which was thought to be able to cause those things it imagined and signified. ${ }^{7}$ This power of imagination became particularly relevant when it was affected by fear since fear was considered to be the necessary precondition for the salvation of souls.

Accordingly, physiological explanations were closely associated with theological ones. Plague was often explicitly described as an act of 'divine violence'. ${ }^{8}$ When sending the plague God punished the sinners and tried and tested the pious; eternal damnation awaited those who, even when suffering this scourge, refused to repent and do penance. Only those who trusted in God's merciful protection were safe from the plague; they knew that God sent the plague as punishment and affliction and that God would be merciful to those who were aware of and accepted this fact. In other words: only those with the right kind of fear would prove to be safe. Only those who tried to change their lives when the plague was approaching would be safe; that is, only those who were afraid of the sin for which the plague was sent as punishment. Those who feared the plague, however, would be taken ill; that is those who were not afraid of the root of

des 17. Jahrhunderts 61 (Reprint of the 1639 edition, Bern, Frankfurt am Main and New York: Lang, 1986), 227, cf. also 224. For examples from the sixteenth century see esp. Montaigne, Essais, bk. 1, chpt. 17, 78: 'C'est ce dequoy j'ay le plus de peur que la peur. Aussi surmonte elle en aigreur tous autres accidents.' 'What I am mostly afraid of is fear. Its violence exceeds any other harm' [my translation].

7 See esp. Johann Werfring, Der Ursprung der Pestilenz. Zur Ätiologie der Pest im loimographischen Diskurs der frühen Neuzeit, Medizin, Kultur und Gesellschaft 2 (2nd ed., Vienna: Ed. Praesens, 1999), 174-222.

8 Johann Wilhelm Mannagetta, Pest-Ordnung...(s.l., 1681), 2. Cf. also Athanasius Kircher SJ, Natürliche und Medicinalische Durchgründung Der laidigen ansteckenden Sucht/ und so genanten Pestilentz... (Augsburg, 1680), 80, 130; Kurtzer/ doch Gründlicher Nach- und Vnterricht/ Wie man sich/nechst Göttlicher Hülffe und Beystand/ bey diesen jetzt besorglichen Zeiten/ in welchen ... die Pestilentzische Fieber und Peste/ in den benachbarten Ländern sich grausam verspüren lassen/von Zeiten zu Zeiten sich ziemlich ausbreiten/ und näher zu unsern Grentzen schleichen/vor solche gifftig-boßhafft anstekkende Krankheiten bester massen prceserviren/schützen/ und bewahren könne... (Brunswick, 1680). 
the punishment but of the punishment itself. ${ }^{9}$ Plague would strike those who relied on their own strengths to avoid falling ill, for instance by using 'magical' devices or by acting without the filial fear of God. Indeed, in the face of its physical effects and its religious causes, fear itself attained the character of a punishment; thus, many contemporaries perceived the fear of the plague to be more damaging than the actual disease. ${ }^{10}$

During the wars of the 'iron century', including the Thirty Years War and the fights against the Turks, not only the fear of the plague but also the fear of military violence had its own violent, sometimes even deadly, consequences. The fear of murderous soldiers, be they Protestants, Catholics or Muslims, or the troops of Gustav Adolf, the Emperor or Grand Vizier Kara Mustafa, produced various physical and psychological illnesses; such fear resulted in life-threatening fevers, premature births and miscarriages or could even be a direct cause of death. Many autobiographical texts tell us that those suffering from this fear might lose their minds, the integrity of their person and finally themselves. Authors like the Augustinian nun Clara Staiger were afraid of the deadly violence of the 'great anxieties of death' because such anxieties, especially when leading to a sudden and unprepared death, endangered not only the body but also the soul and thus appeared to be a 'well-deserved divine punishment'. In a sense, authors like Staiger were afraid of feeling fear. ${ }^{11}$

Balthasar Kleinschroth, secular priest and prefect of the singing school in the Cistercian Abbey of the Holy Cross in the Vienna Woods, provides another example of this phenomenon. As he tells us in his diary (1686), he had to 'pay with his skin' for the 'terror and the serious worries' that he had endured during the siege of Vienna in 1683: he was suffering from

9 Theophrastus Paracelsus, 'De pestilitate', in Paracelsus, Werke, ed. Will-Erich Peuckert, 5 vols. (2nd ed., Basel and Stuttgart: Schwabe, 1982), vol. 5, 176-261, there 240-241.

10 Mannagetta, Pest-Ordnung, 32-34; see also 19-20; Johann Quistorp, Quatuor Novissima Oder fünff vnd funfftzig Predigten/ darin die männiglich hochnötig zu wissende Lehre Vom Tod vnd Abesterben/Von dem künfftigen algemeinen Gericht/ Von der Hellen vnd Hellen Pein/Von dem Ewigen Leben vnd Himmels Frewde/verhandelt wird. Neben angehengten sechßzehen Predigten von der Pestilentz (Rostock, 1629), 485-486; Georg Daniel Coschwitz and Christian Sigismund Finger, Timoris et terroris in peste noxa (Halle an der Saale and Magdeburg, 1722), 3.

11 Clara Staiger, 'Verzaichnus', in Klara Staigers Tagebuch. Aufzeichnungen während des Dreißigjährigen Krieges im Kloster Mariastein bei Eichstätt, ed. Ortrun Fina (Regensburg: Pustet, 1981), ff. 80-81, 357; Junius, Verzeignuß, 29, 34, 57-58, 74, 156; 'Aufzeichnungen des Pfarrers Plebanus von Miehlen aus den Jahren 1636/37', ed. Ferdinand Heymach, Nassauische Annalen 38 (1908), 255-285, there 281. Cf. Schottelius, Ethica, 221. On Staiger cf. Mortimer, Eyewitness Accounts, 96-111, 180-181; Woodford, Nuns, esp. 106-116, 125-143; Kormann, Ich, Welt und Gott, chpt. II.B.2. 
attritis or glidersucht. Kleinschroth tried various medical therapies, both against the consequences of the 'ingested terror' and against the terror itself, but these therapies did not get at the cause of the problem. ${ }^{12}$ It was not until the 'Turkish threat' had been overcome that Kleinschroth got a real chance to recover:

These days [shortly after September 12, 1683], we heard the joyous news, that last Sunday the city of Vienna had been happily relieved. Immediately, the Patres reminded me that on this day I had been delightfully relieved of my own besiegement, that is, in my own words, that I was no longer confined to bed.

Kleinschroth plays on words: he associates the German word 'Belagerung' (besiegement) with 'Bettlagerung' (confinement in bed). But this construction was not merely a pun. The analogy of the patient's 'anxiety' with the 'anxiousness' of the besieged city ${ }^{13}$ was considered to be not only lin-

12 Balthasar Kleinschroth, Flucht und Zuefluchts Eigentliche und Wahrhaffte beschreibung, welche sich zuegetragen in der Türckhischen und Tarterischen Landesverwiestung in Österreich Anno 1683 ... (Stiftsarchiv Heiligenkreuz, Rubr. 3/Fasc. V), ff. 204r-216v, 251v, 281r, 29or (the quotations are on ff. $251 \mathrm{v}$ and 281r). The text is cited below as Flucht und Zueflucht. Two-thirds of the manuscript have been edited by P. Hermann Watzl S.O. Cist. as Flucht und Zuflucht. Das Tagebuch des Priesters Balthasar Kleinschroth aus dem Türkenjahr 1683, Forschungen zur Landeskunde von Niederösterreich 8 (2nd ed., Graz and Cologne: Böhlau, 1983) (cited below as Tagebuch); see 179-183.

13 For the 'anxiousness' of the city (and not only of its inhabitants) see Christoph Fürer von Haimendorf, Die bekriegte/ und triumphirende Donau in Londen eingeführt und vorgestellt/ Als des Kayserlichen Herrn Abgesandtens in Engelland etc. Hrn. Grafen von Thun Excellentz alldorten die Nachricht erhalten/Vber Den Entsatz Der Von TVrCken/VIeL geängstIgten StaDt VVIen (Nuremberg, 1683); Georg Christoph von Kunitz, Diarium Welches Der am Türckischen Hoff / und hernach beym Groß-Vezier in der Wienerischen Belägerung gewester Kayserl. Resident Herr Baron Kunitz eigenhändig beschrieben ... (s.l., 1684), f. B ir; Johann Ferdinand Fischer, Diarium, Oder Weitläuffig und gründliche Beschreibung/ von der Käys. Haupt- und Residentz-Stadt Wien/ In Unter-Oesterreich/ im Viertel unterm Wiennerwald liegend; welche vom 14. Julij/ biß 12. Septemb. Anno 1683. 61. Tag von des Türckischen Käysers Sultan Machomet Kriegs-Volck ... ist belägert worden ... (Regensburg, s.a.), [10]; Vaelckeren, Wienn, 94, cf. also 88; Happel, Der Ungarische Kriegs-Roman, 658, 772; Christian Wilhelm Huhn, Nichts Neues und Nichts Altes/ oder umbständliche Beschreibung, Was Anno 1683. Vor/ bey und in der Denckwürdigen Türckischen Belagerung Wien, vom 7 Julii biß 12 Septembr. täglich vorgelauffen ... (Breslau, 1717), 70-71, cited in Walter Sturminger, Die Türken vor Wien in Augenzeugenberichten (Munich: dtv, 1983), 135; Johann Martin Lerch, Warhaffte Erzehlung: Welcher gestalt in der ängstlichen Türckischen Belägerung der Käyserlichen Haupt- und Residentz-Stadt Wien in Oesterreich Durch das feindliche Lager gedrungen/ und die erste Kundtschafft zur Käyserlichen Haupt Armada, wie auch von dar glücklich wieder zuruck gebracht worden (s.l., 1683), f. 3r, cf. f. 1v. Cf. also Erasmus Francisci, Schau- und Ehren-Platz Christlicher Tapfferkeit/ Das ist: Aller Denck- und Ruhmwürdig ausgestandenen Belägerungen der Weltberühmten Römisch-Käyserlichen Ansitz-Stadt Wien in Oesterreich... (Nuremberg, 1684), 1-4, esp. 3. M.M.S., Ausführ- und gründliche Erzählung dessen/was sich vor würklicher Belagerung der Käiserlichen Haupt- und Residenz-Stadt 
guistic but also causal. ${ }^{14}$ As indicated by its etymology, the word 'anxiety' was used to describe the feeling of being confined and oppressed in an affective sense but referred as well to the spatial, physical impact of this affect. ${ }^{15}$

Neither Kleinschroth nor the city of Vienna was relieved of their dangerous anxieties and besiegement until God put their enemies to flight. As numerous eyewitnesses tell us, He did so by terrifying the 'Turks' with the fearlessness of the Christian soldiers trusting in His merciful protection; that is, by leading the Ottoman forces to military defeat and making them aware of His might. ${ }^{16}$ God tried the pious, and He made sinners afraid of those fearless believers who had overcome the temptation to give in to fear. This mechanism is also impressively manifest in the autobiography of the Jesuit polymath Athanasius Kircher (1602-1680). The Vita is believed to have been written in the late 1660 s and was posthumously discovered and published by his confreres in the Collegium Romanum in Rome, where Kircher had lived since 1633, after fleeing the atrocities of the Thirty Years War. ${ }^{17}$

Wienn in Oesterreich/ im Jahr Christi M. DC. LXXXIII. zugetragen (Nuremberg, 1684), 63, characterises Vienna as a 'dungeon of anxiety'.

14 Kleinschroth, Flucht und Zueflucht, f. 214r, cf. also f. 206v; Tagebuch, 182 [my translations]. For further details and bibliographical references see Andreas Bähr, Furcht und Furchtlosigkeit. Göttliche Gewalt und Selbstkonstitution im 17. Jahrhundert, Berliner Mittelalter- und Frühneuzeitforschung 14 (Göttingen: V\&R unipress, 2013), chpt. 5.3.

15 See 'Angst', in Zedler (ed.), Universal Lexicon, vol. 2, cols. 301-304, there 301, 304; Michael Stolberg, "'Zorn, Wein und Weiber verderben unsere Leiber". Affekt und Krankheit in der Frühen Neuzeit', in Johann Anselm Steiger (ed.), Passion, Affekt und Leidenschaft in der Frühen Neuzeit, Wolfenbütteler Arbeiten zur Barockforschung 43 (Wiesbaden: Harrassowitz, 2005), vol. 2, 1051-1077, there 1060-1061, 1072-1073; Hartmut Böhme, 'Vom phobos zur Angst. Zur Transformations- und Kulturgeschichte der Angst', in Martin Harbsmeier, Sebastian Möckel (eds.), Pathos, Affekt, Emotion. Transformationen der Antike (Frankfurt am Main: Suhrkamp, 2009), 154-184, there 168-169. On the early modern concept of 'anxiety' cf. also Hartmut Lehmann, "'Not, Angst und Pein". Zum Begriff der Angst in protestantischen Kirchenliedern des späten 16. und des frühen 17. Jahrhunderts', Zeitschrift für Kirchengeschichte 117 (2006), 297-310.

16 Georg Christoph von Kunitz, Diarium... Nebst außführlicher Relation Der Wienerischen Belägerung... (s.l., 1684), ff. A ir, A 3v-B ir.

${ }_{17}$ I quote here from John Fletcher's translation of the printed version (Vita Admodum Reverendi P. Athanasii Kircheri..., annexed to Fasciculus epistolarum Adm. R.P. Athanasii Kircheri Soc. Jesu ..., ed. Hieronymus Ambrosius Langenmantel (Augsburg, 1684)): Athanasius Kircher SJ, Vita, in John Edward Fletcher, A study of the life and works of Athanasius Kircher, 'Germanus incredibilis'. With a selection of his unpublished correspondence and an 
In 1623 , as Kircher tells us, when he was on his way to the theological college of the Society of Jesus in the Saxonian city of Heiligenstadt, he had a remarkable 'misadventure'. Although Kircher 'had to pass through many places occupied by non-Catholics', he did not pay heed to those well-meaning colleagues and friends who urged him to conceal his affiliation to the Jesuit order while en route; he preferred to 'die dressed in my Order's habit than [to] travel unmolested in secular clothing'. ${ }^{18}$ In the 'wild' and 'horrid' 'Valley of Hell' (Höllental), Kircher did not have to wait very long for this threat to materialise. ${ }^{19}$ He was surrounded by Lutheran horsemen who were camped in the woods, duly recognised as a Jesuit, robbed, beaten and injured. What is more, since these 'brutal fellows' proved to be not only possessed by avarice but also by 'implacable hatred against Jesuits', they prepared to hang their victim and led Kircher to the tree they used for executions. ${ }^{20}$

Recognising his situation as hopeless, Kircher collected his thoughts, fell to his knees, raised his eyes to heaven 'and in tears recommended myself with immense fervour to God and the Mother of God'. Kircher prepared himself for martyrdom: 'I thanked [the] benevolent God for deeming me worthy to suffer death for the honour of His most holy name'. Tears poured from his eyes and produced a remarkable effect. As tears flowed out, consolation flowed in: 'All my terror had vanished and I felt the greatest readiness to surrender to God my life and body'. By being tearfully fearless, however, and in preparing composito animo for what he initially had been afraid of, Kircher was able to avert the threat. When one of the attackers saw the abundant tears of his victim, he was 'seized with [such] compassion' that he urged his fellow soldiers not to soil their hands with the blood of an innocent man. Jesuits were evil, no doubt, but

annotated translation of his autobiography, ed. Elizabeth Fletcher, Aries Book Series. Texts and Studies in Western Esotericism 12 (Leiden, Boston: Brill, 2011), 459-551, there 480-481. The manuscript is entitled Vita R.P. Athanasii Kircheri S.J. Romce in Collegio Romano post obitum eius inventa, ibidemque, agente R.P. Conrado Holtgreve, cum facultate R.P. Provincialis Romani 7. Sept. anno 1682 primùm, deinde iterum anno 1683 descripta Neuhusij à J.K. S.J. (Hochschul- und Landesbibliothek Fulda, Hs. $8^{\circ} \mathrm{B} 103$ ); the relevant passage is on $\mathrm{ff.}$ 22v-25r.-We do not know whether Kircher wrote his autobiography only for his confreres (as Ignatius of Loyola did when relating his own life story to Jerónimo Nadal) or if he was addressing the broader audience reached by the posthumous publication of the text.

18 The Fulda manuscript speaks of 'heretics' (loca hceretica): Vita R.P. Athanasii Kircheri, f. 23 r.

19 According to Kircher, the valley is situated between Eisenach and Marksuhl: Kircher, Vita, 480.

20 Ibid., 480. 
Kircher should not suffer for that. Whoever killed this man, the speaker proclaimed, would face divine punishment. Moved by their comrade's remonstrations, the other soldiers let Kircher go and returned his stolen goods. And what is more: 'seized by panic, they fled into the forest, leaving me alone with my clothes and the papers I had been carrying'. Kircher's saviour, however, came back alone in order to ask Kircher to intercede for him so that God might not find him guilty of the crime and to urge Kircher to leave this dangerous place. This time, the traveller took the advice and thanked the Almighty for mercifully protecting him-albeit 'lamenting ... that such an opportunity of dying for the honour of God had been taken from me'.21

Athanasius Kircher had been threatened with death; although terrified he overcame his fear, and in doing so terrified his attackers. At first, the soldiers' 'anxiety' (pavor) appears to be the terror of their conscience upon recognising their offence and its expected consequences. But how can it be explained that these soldiers not only listened to reason and let Kircher pass but also withdrew into the forest, filled with 'panic'? Why did Kircher's fearlessness have such a powerful impact? Again, the answer lies in the notion of providence. God punished the sinners by making them fear, and He made them fear by confronting them with the fearlessness of a God-fearing believer who was willing to suffer. Not only in eternity but also on earth, fearlessness dispelled fear by disposing of its rationale. No one who feared God need be fearful, and that sort of fearlessness might in turn terrify others into a fear of God. The soldier, who saved Kircher's life, admired and revered him because he recognised him as a man whom God had released from fear.

The soldier's change of heart appears to have resulted from religious and moral reflection not shared by his comrades who fled in 'panic'; that is, they took flight without being aware of the true nature of the dangers threatening them. In contrast to the qualms of conscience felt by Kircher's protector, this panic was considered an indication of mental and psychic disintegration, the same 'loss of reason' that Clara Staiger had already noted was more terrifying than the death of the body. ${ }^{22}$ Because Kircher was not afraid of dying, those threatening him with death became concerned about their souls. Yet instead of engaging in spiritual and moral self-examination, these soldiers fled from God's countenance. Their

21 Ibid., 480-481.

22 Staiger, 'Verzaichnus', ff. 8o-81, cf. f. 357. 
panicked anxiety would not save them from the terrifying punishment that they sought to avoid. Such anxiety was not only a response to a warning of eternal sanctions: it was the very divine punishment which they dreaded. This fear mirrored the offence: Kircher's fearlessness struck fear into those who had previously made him afraid. In displaying such panic, these soldiers did not atone for their guilt but gave proof of it.

In these examples, those who were fearful or fearless do not appear to be acting subjects. According to his autobiography, Athanasius Kircher had by no means foreseen what would happen to him. The aggressors could be driven away by their victim because Kircher did not act to repel them himself but left his rescue up to God's benevolent power. Kircher prepared himself for martyrdom and even provoked it, and this decision made possible his survival because he refrained from taking action by 'himself. The same is true of those who got into a 'panic'. They did not act themselves but were violently 'seized', as Kircher puts it, or, to quote Maria Anna Junius, they were physically 'stricken and driven away'. ${ }^{23}$ It is not human subjects, who are acting here but their affects, and this implies that it is really God who is at work. ${ }^{24}$ What becomes manifest here is a specific early modern concept of the acting person.

In Kircher's depiction of the scene there are various elements flowing in and out: tears and consolations, blood and life. This process appears to be a physical one and thus, it has a specific spatial structure. It was in this space that fear and fearlessness attained their violent power. In the seventeenth century, the inner space of the person did not qualitatively differ from his outer world, and the space of affects did not differ from the space of action. To put it differently: the elements of the world and human and divine occurrences were considered to be closely connected by semiotic and causal interrelations, by relations of analogy and similarity. The 'person' causing fear and being 'filled' with fear was not yet conceptualised as an individual self, psycho-physically closed, but as both a medium and an arena of the cosmic battle between good and evil. ${ }^{25}$

23 Junius, Verzeignuß, 207.

24 Cf. Böhme, 'Vom phobos zur Angst', 163.

25 On early modern concepts of person see Michel Foucault, The order of things. An archaeology of the human sciences (1966, London and New York: Routledge, 2002); Clifford Geertz, "From the native's point of view". On the nature of anthropological understanding', in Janet L. Dolgin, David S. Kemnitzer and David Murray Schneider (eds.), Symbolic anthropology. A reader in the study of symbols and meanings (New York: Columbia University Press, 1977), 480-492, there 483; Ralf Konersmann, Kulturelle Tatsachen (Frankfurt am Main: Suhrkamp, 2006), 188; Claudia Benthien, Skin. On the cultural border between self 
It was not until the late eighteenth century that 'feelings' were regarded as invisible to the eye and unrepresentable by language, that the horde of spirits started being driven out of the world of nature and men, and that the soul was psychologised. Only in the Enlightenment was the interiority of the 'subject' imagined as an inaccessible space clearly separate from the space of exanimate 'objects'. In Enlightenment thought, fear and fearlessness lost their violent power.

When historicising early modern memories of fear we have to analyse not only the historical notions but also the functions of 'fear' and 'anxiety': we have to ask not only what people wrote about fear but also why they did so. Not only Catholic authors like Junius, Staiger, Kleinschroth and Kircher but also many Protestants described their own fear as being an earlier condition: those telling us that they had been frightened in the past and that their anxieties had been an act of divine violence introduced themselves as being 'converted' into their present state of fearless and God-fearing believers. ${ }^{26}$ Anyone able to talk about the fear of violence and the violence of fear already seemed to have defeated and overcome both. Fear and fearlessness operated in conjunction; the power of fear and the possibilities of disempowering it were mutually constituent. This is true, regardless of whether these authors wrote their diaries comparatively shortly after the relevant events or composed their autobiographies at the end of their lives, using, as Kircher did, various literary templates from hagiography and martyrologies. What is more, the religious epistemology underlying these narratives cannot be found only in war memoirs written by clerics or nuns but also in those written by laymen, e.g., in the autobiography of the Calvinist tradesman Augustin Güntzer. ${ }^{27}$

and the world (1999, New York: Columbia University Press, 2002). The spatial implications of these concepts of person become particularly manifest in autobiographical depictions of divinatory dreaming which can also be found in Kircher, Vita, 13-14. See Andreas Bähr, 'Spaces of dreaming. Self-constitution in early modern dream narratives', in David Sabean and Malina Stefanovska (eds.), Space and self in early modern European cultures, UCLA Clark Memorial Library Series 18 (Toronto: Toronto University Press, 2012), 219-238.

26 See Bähr, Furcht, chpt. 5.2.

27 Augustin Güntzer, Kleines Biechlin von meinem gantzen Leben. Die Autobiographie eines Elsässer Kannengießers aus dem 17. Jahrhundert, ed. Fabian Brändle and Dominik Sieber, Selbstzeugnisse der Neuzeit 8 (Cologne, Weimar and Vienna: Böhlau, 2002). 
We can thus conclude from historical depictions of fear that contemporaries held 'fear' and 'anxiety' to be crucial for processes of self-constitution and self-preservation. We should, however, not extend this understanding to conclude that the seventeenth century was an 'age of anxiety' in the psychohistorical sense of the term. Anyone trying to find out what people 'really' felt in the past is in the position of applying modern concepts of fear to historical and cultural contexts in which a psychological epistemology was unknown. For seventeenth-century authors 'fear' and 'anxiety', both their own and in others, were not interior mental experiences but rather a divine scourge.

Such a conceptualisation of fear and anxiety granted seventeenthcentury war memoirs functions very different from modern ones. Time and again, autobiographers and chroniclers articulated the desire to fall silent, ${ }^{28}$ and they underlined the 'ineffability' and 'indescribability' of their fear; however, in the end they decided to speak. They did not claim that individual suffering was inexpressible in itself but rather that no physical sheet of paper would prove large enough to record every single distressing event. It was a matter of quantity not quality. Thus, these authors did not try to forget but encouraged remembering (memoria). ${ }^{29}$ When recall-

28 E.g. 'Selbstbiographie des Stadtpfarrers Wolfgang Ammon von Marktbreit († 1634)', ed. Franz Hüttner, Archiv für Kulturgeschichte 1 (1903), 50-98, 214-239, 284-325, there 87; Sebastian Bürster, Beschreibung des schwedischen Krieges 1630-1647, ed. Friedrich von Weech (Leipzig: Hirzel, 1875), 87; Friedrich Hoppe, Johann Georg Mauls Diarium aus dem Dreißigjährigen Kriege (Naumburg an der Saale: Sieling, 1928), 7-8; Franz Martin, 'Das Hausbuch des Felix Guetrater 1596-1634', Mitteilungen der Gesellschaft für Salzburger Landeskunde 88/89 (1948/49), 1-50, there 34; Conrad Burger, 'Itinerarium', published as 'P. Konrad Burgers Reisebüchlein', ed. P. Gregor Müller, Cistercienser-Chronik 43-45 (1931-1933), vol. 43, 129 .

29 E.g. Junius, Verzeignuß, 154, 221; Bürster, Beschreibung, 1-2, 114; Gerd Zillhardt, Der Dreißigjährige Krieg in zeitgenössischer Darstellung. Hans Heberles 'Zeytregister' (1618-1672). Aufzeichnungen aus dem Ulmer Territorium. Ein Beitrag zu Geschichtsschreibung und Geschichtsverständnis der Unterschichten, Forschungen zur Geschichte der Stadt Ulm 13 (Ulm: Kohlhammer, 1975), 121, 159; Walter Kürschner, 'Aus dem Kirchenbuch von Reichensachsen (und Langenhain) von 1639-1653', Archiv für hessische Geschichte und Altertumskunde N.F. 9 (1913), 48-55, there 53; Burger, 'Itinerarium', vol. 43, 129; Gerhard Bätzing, 'Auszüge aus den ältesten Kirchenbüchern von Besse', Zeitschrift des Vereins für hessische Geschichte und Landeskunde 83 (1972), 97-135, there 124; G. Sello, 'Eine Potsdamische Pfarrchronik aus der Zeit des großen Krieges', Zeitschrift für preußische Geschichte und Landeskunde 20 (1883) (reprint 1973), 207-234, there 233; 'Aus den Predigten des Pfarrers Hartmann Kreid (1636-1650)', in Die Chroniken von Friedberg in der Wetterau, ed. Christian Waas, vol. 2 (Friedberg: Bindernagel, 1940), 1-25, there 13; Kircher, Vita, 483; Kleinschroth, Tagebuch, 91, 130, 195. For further details and bibliographical references see Bähr, Furcht, chpt. 5.2 and 5.3. On 'ineffability' as a rhetorical pathos formula cf. Claudia Benthien, 
ing their fear, they looked not only into the past but also into the future. They called on their readers to repent in order to prevent reoccurrence of past events; ${ }^{30}$ they sought to avert that divine punishment that no human being could escape without God's mercy and grace. ${ }^{31}$ In seventeenthcentury Germany, strategies for coping with fear as well as (the concept of) fear were shaped by religion. ${ }^{32}$ To overcome fear was therefore not a matter of individual well-being and therapeutic self-enhancement but rather a religious demand. In addition to being required to suffer from fear and anxiety in this world, Christians were also required to control these affects and to transform them into the righteous fear of God. Accordingly, writing about fear did not have the psychological objective of overcoming it; rather overcoming fear was a precondition for writing about it. Describing the fear of violence was not regarded and applied as an instrument for coping with 'psychic trauma' in the modern sense of the term. ${ }^{33}$ Those who remembered the war had survived (and that is why they were able to remember), but they wanted more than mere survival. When writing about their past fears they sought to religiously and morally preserve themselves for the future. In doing so, however, they did not describe themselves as autonomous, 'feeling' subjects. ${ }^{34}$ Those who recalled their fears effectively told their readers that they had already defeated these

Barockes Schweigen. Rhetorik und Performativität des Sprachlosen im 17. Jahrhundert (Munich: Fink, 2006).

30 This aspect has been neglected by Peter Sherlock, 'The reformation of memory in early modern Europe', in Susannah Radstone, Bill Schwarz (eds.), Memory. Histories, theories, debates (New York: Fordham University Press, 2010), 30-40.

31 Should the call go unheeded, a new war might break out. Tobias Wagner, for example, was convinced that after 1663 , God punished the Christians with the 'Turks' for having ignored the religious message of the Thirty Years War: Tobias Wagner, Türcken-Büchlein/ Das ist: Summarische Beschreibung deß Ottomanischen Hauses Herkommen/ und Kriegen/ biß auf gegenwärtige Zeiten ..., (2nd ed., Ulm, 1664), 219-220.

32 This is not to say that religion was (and is) caused by fear, as has been asserted by numerous historians and scholars of religion, drawing both on Enlightenment and ancient debates. See Bähr, Furcht, chpt. 2.2 and 2.3.

33 For a psychohistorical approach towards the history of the Thirty Years War cf. Bernd Roeck, 'Der Dreißigjährige Krieg und die Menschen im Reich. Überlegungen zu den Formen psychischer Krisenbewältigung in der ersten Hälfte des 17. Jahrhunderts' [1996], in Peter Claus Hartmann and Florian Schuller (eds.), Der Dreißigjährige Krieg. Facetten einer folgenreichen Epoche (Regensburg: Pustet, 2010), 146-157; Johannes Burkhardt, Der Dreißigjährige Krieg (Frankfurt am Main: Suhrkamp, 1992), 233-244.

34 On the concept of survival and its interrelation with 'trauma' and 'self-preservation' see Falko Schmieder, 'Überleben-Geschichte und Aktualität eines neuen Grundbegriffs', in Falko Schmieder (ed.), Überleben. Historische und aktuelle Konstellationen (Munich: Fink, 2011), 9-29. 
affects - by having knowledge of their violent impact and its causes and therefore being aware that fear and anxiety could not be defeated without the help of God's providence. Memories like these were associated not only with 'horror' but in some cases also with 'joy' - the grateful joy of having been relieved of a suffering that true Christians had to endure: the joy of having suffered, as a sign of salvation. ${ }^{35}$

35 Kleinschroth, Tagebuch, 44, 133, 146; Flucht und Zueflucht, f. 251v. Schottelius, Ethica, 179-180, speaks of 'joyous horror'. See also the chronicle of Johann Strahm from Ostheim near the Rhön (1657), published in Karl Zeitel, 'Die kirchlichen Urkunden im Kirchturmknopf der Michaeliskirche in Ostheim v. d. Rhön. Ein Blick in die Kirchen-, Schul- und Kulturgeschichte der Stadt Ostheim v. d. Rhön', Jahrbuch des Hennebergisch-Fränkischen Geschichtsvereins 19 (2004), 219-282, there 233-239, esp. 233 (f. 1r): 'Praeteritorum malorum recordatio jucundissima est. 'For a different interpretation of Strahm's account cf. Hans Medick, 'The Thirty Years War as experience and memory. Contemporary perceptions of a macro-historical event', in Lynne Tatlock (ed.), Enduring loss in early modern Germany. Cross disciplinary perspectives, Studies in Central European Histories 50 (Leiden and Boston: Brill, 2010), 25-49, esp. 35-36. 


\title{
PERMEABLE MEMORIES. FAMILY HISTORY AND THE DIASPORA OF SOUTHERN NETHERLANDISH EXILES IN THE SEVENTEENTH CENTURY*
}

\author{
Johannes Müller
}

When John La Motte died in London in 1655 he was widely known and celebrated as an exemplary Christian, whose life bore such a powerful testimony to his piety and godliness that the Puritan author Samuel Clarke included La Motte's biography in his work on 'The lives of sundry eminent persons in this later age'. ${ }^{1}$ La Motte had served the city of London as an alderman and the local Dutch Reformed Stranger Church as an elder and deacon. In this function he had organised relief funds for persecuted Calvinists in Bohemia and Piedmont and made vigorous efforts on behalf of his afflicted coreligionists on the continent. A crucial element in the hagiographical accounts of his life was his own heritage of religious exile and persecution: La Motte was born in Colchester to Flemish parents who had left their hometown of Ypres for England during the persecution under the duke of Alba in the late 156os. According to his biographers, it was due to his parents' uncompromising allegiance to their Reformed faith that their son grew up as a devout and pious man who did not ignore the fate of his persecuted coreligionists abroad. In his funeral sermon, preached by Fulk Bellers, La Motte was even compared to the patriarch Abraham who had left his homeland of Chaldea to seek the land God had promised him. But even during his lifetime La Motte seems to have compared himself with Biblical exiled heroes as Moses and Abraham: on occasions like the Accession Day of Elizabeth I or his own birthday he used to invite friends to meet at his home and as

he would often say, he had desired their company, to eat bread with him before the Lord (as Jethro and Moses did) in remembrance of such and such signal mercies and deliverances, whereof his memory was a living chronicle,

\footnotetext{
* Research for this article was funded by an NWO VICI grant for the research project Tales of the Revolt. Memory, oblivion and identity in the Low Countries, 1566-1700.

1 Samuel Clarke, The lives of sundry eminent persons in this later age (London, 1683) part 2, 102.
} 
especially those grand deliverances, both before and since the Reformation, from under the great sufferings and bloody persecutions in France, and the Low Countries, whereof he would often discourse in so punctual and feeling a manner, as if he had been an eye-witness, yea a sharer in them, taking many arguments thence of encouraging both himself and others, to be still mindfull of them in bonds and miseries, as being themselves in the body: saying, why, their case might have been ours, or may be yet, who knows? [Beller's italics] ${ }^{2}$

The remembrance of his forefathers who had left Flanders for England evidently played a central role at these commemorative meetings. Obviously, La Motte, though born in England and participating in the local politics of London as an alderman of the city, strongly identified with his parents' exile. His sense of belonging to a diaspora of Reformed refugees all over Europe seems to have been a cornerstone of his religious identity and personal devotion. ${ }^{3}$

According to Peter Ole Grell, people like La Motte belonged to the last generation of the international Calvinist diaspora. In the next generation, Grell argues, the bond with the exile heritage of their forefathers became diluted and individuals began to conceive of themselves primarily as Dutch, German or English rather than as exiled strangers in a foreign land. Grell's observation seems to be accurate in general: the children of La Motte and his contemporaries did indeed marry into English, German or Dutch families and became absorbed in the host societies of their

2 Fulk Bellers, Abrahams Interment, or, The good old-mans buriall in a good old age. Opened in a sermon at Bartholomews exchange, July 24, 1655, at the funerall of the worshipfull John Lamotte, Esq., sometimes alderman of the city of London (London, 1656), f. F4ff.

${ }^{3}$ On the Netherlandish diaspora during the Dutch Revolt see for example: Heinz Schilling, Niederländische Exulanten im 16. Jahrhundert. Ihre Stellung im Sozialgefüge und im religiösen Leben deutscher und englischer Städte (Gütersloh: Gütersloher Verlagshaus, 1972); Heinz Schilling,'Die frühneuzeitliche Konfessionsmigration', in Klaus J. Bade (ed.), Migration in der europäischen Geschichte seit dem späten Mittelalter (Osnabrück: IMIS, 2002), 67-89; M. Backhouse, The Flemish and Walloon communities at Sandwich during the reign of Elizabeth I, 1561-1603 (Brussels: Koninklijke Academie voor Wetenschappen, Letteren en Schone Kunsten van België, 1995); A. Dünnwald, Konfessionsstreit und Verfassungskonflikt. Die Aufnahme der Niederländischen Flüchtlinge im Herzogtum Kleve 1566-1585 (Bielefeld: Verlag für Regionalgeschichte, 1998); Raingard Esser, Niederländische Exulanten im England des 16. und frühen 17. Jahrhunderts (Berlin: Duncker \& Humblot, 1996); J.C.A. Briels, Zuid-Nederlanders in de Republiek 1572-1630. Een demografische en cultuurhistorische studie (Sint-Niklaas: Danthe, 1985); Peter Ole Grell, Calvinist exiles in Tudor and Stuart England (Aldershot: Scolar, 1996); Andrew Pettegree, Emden and the Dutch revolt: exile and the development of Reformed Protestantism (Oxford: Oxford University Press, 1992); Andrew Spicer, The French-speaking Reformed community and their church in Southampton, 1567c.1620 (London: Huguenot Society of Great Britain and Ireland, 1997). 
parents. ${ }^{4}$ However, as I will show in this chapter, even among these later generations memories of exile continued to be preserved and transmitted, not only in the various stranger churches but also, and perhaps more prominently so, in family circles. Intermarrying with locals and participating in the social and political life of their new host societies did not prevent migrants and their descendants from continuing to appropriate and refashion the diasporic identities of their forefathers. The exile memories of subsequent generations of migrants were, of course, not the same as those of their forebears and had to be translated into the specific context of each new generation and its living conditions in a changing society. In genealogical accounts, letters and other sources, the children and grandchildren had to reinvent and reinterpret the past of their ancestors on their own terms. As I will demonstrate on the basis of a selection of family histories of migrant families from the Southern Netherlands, the same accounts were often rewritten generation after generation. By comparing the various hands and examining crossed-out passages in the text, I was able to attribute the various changes to specific family members from later generations. As these additions and modifications of the chronicles show, the exile narrative was often blended with discourses that were shared with the native societies in which the migrants lived.

\section{Beyond the 'Memory Ghetto'}

Many studies on memory cultures among migrants, displaced groups and individuals argue that such people develop exclusive discourses about their past, which are clearly distinguishable from the memory cultures of their host societies. In many cases, migrant communities even form isolated 'memory ghettos', into which their members seclude themselves. ${ }^{5}$ These exclusive memory cultures set them apart from the rest of society and cannot easily be shared with people outside one's own minority group. In many cases, the discourses in which images of the past are

4 Ole Peter Grell, Brethren in Christ. A Calvinist network in reformation Europe (Cambridge: Cambridge University Press, 2011) 307.

5 See e.g.: Andreas Kitzmann, 'Frames of memory. WWII German expellees in Canada', in Julia Creet and Andreas Kitzmann (eds.), Memory and migration. Multidisciplinary approaches to memory studies (Toronto: University of Toronto Press, 2011), 93-119; Lauren Guyot, 'Locked in a memory ghetto. A case study of a Kurdish community in France', in Creet and Kitzmann (eds.), Memory and migration, $135^{-155}$. 
articulated within a migrant community prove incompatible with the collective memories of their host society and its imagination of the past. In such cases, the distinctive migrant identity is reproduced and marks a clear difference between migrants' own imagined community and that of their neighbors without a migration background.

Without denying the existence of such memory ghettos, this chapter will argue that it would be a mistake to consider them typical of migrant experiences of the past. In early modern Europe, at least, we can find alternatives. I will show that the numerous Southern Netherlandish refugees who left their homelands during the second half of the sixteenth century to escape religious persecution as well as military devastation did not live in such isolated memory ghettos at all. Even though they developed extremely vivid memory cultures and preserved their identity as religious exiles for centuries, the discourses in which their memories were articulated and transmitted were never totally separated from the memory canons of their host societies. On the contrary, exile memories and identities incorporated collectively shared narratives about the past of the inhabitants of their new hometowns. For people belonging to the international diaspora of Reformed migrants from the Southern Netherlands, their diasporic identity was not an all-encompassing narrative but rather one that could coexist and be combined with memories of the various host societies in which they found themselves. In many cases, migrants could even benefit from the fashioning of a distinctive exile identity: as the case of John La Motte shows, remembering the history of confessional persecution was not an issue that divided migrants and native Protestants but rather one that united them in their collective identification with the same religious cause. The commemorative meetings organised by La Motte were frequented by English Puritans as well the descendants of Flemish refugees, and it is no coincidence that they were held on the Accession day of Queen Elizabeth I, who was already celebrated as a champion of Protestantism and had long been commemorated as a loyal host by Netherlandish exiles. ${ }^{6}$

The assumption that migrants and their descendants develop and limit themselves to exclusive identities that separate them from other groups in

6 See e.g.: Simeon Ruytinck, 'Gheschiedenissen ende handelingen die voornemelick aengaen de Nederduytsche natie ende gemeynten, wonende in Engelant ende int bysonder tot Londen, vergadert door Symeon Ruytinck, Caesar Calandrinus ende Aemilius van Culenborgh, dienaren des Godlicken Woords', in J.J. van Toorenenbergen (ed.), Werken der Marnix-vereeniging, 3d series, nr. 1. (Utrecht: Marnix-Vereniging, 1873), 162. 
society has often led to the assumption that they have only two options to choose from: either they preserve their own identities and former national allegiances, or they assimilate and loosen their ties with the 'Old Country'. This notion has been criticised by scholars like Matthew Frye Jacobson, Michael Peter Smith and Nina Glick Schiller, who argue that migrant identities should not be understood in terms of assimilation and integration, on the one hand, and the preservation of old identities, on the other. ${ }^{7}$ Rather, the experience of migration should be described as producing a 'multiple emplacement or situatedness both here and there', as Michael Peter Smith has put it. Instead of belonging only to the migrant diaspora or the local society they live in, the migrants experience a 'cultural bifocality', which connects the country of origin with the new homeland. ${ }^{8}$ While studies on early modern refugees from the Netherlands have sought to determine at which point individuals ceased to identify themselves with their exile past and started to see themselves as German, English or Dutch, I suggest a change of focus; I will ask how exile identities and memories of flight and persecution were translated into German, Dutch and English contexts. ${ }^{9}$ As the following cases show, neither political participation in the new society nor intermarrying with locals put an end to the memory cultures of the migrants. While being fully 'assimilated', the descendants of Flemish refugees continued to refer to their forefathers' past until the eighteenth century or even later. Paradoxically, in many cases it was the very exile-narrative itself that allowed for participation and integration in local social systems and networks. When migrants were successful in claiming to have suffered much for the 'True Faith', they could use such claims to gain a higher social status among their coreligionists in their new hometowns, as the following examples will show.

7 Matthew Frye Jacobson, Special sorrows. The diasporic imagination of Irish, Polish and Jewish immigrants to the United States (Berkeley and Los Angeles: University of California Press, 2002); Nina Glick Schiller, Linda Basch and Cristina Szanton Blanc, 'From immigrant to transmigrant. Theorizing transnational migration', Anthropological Quarterly 68 (1995), 48-63; Michael Peter Smith, Transnational urbanism. Localizing globalization (Malden, MA: Wiley-Blackwell, 2001).

8 Michael Peter Smith, 'Translocality: A critical reflection', in Katherine Brickell and Ayona Datta (eds.), Translocal geographies. Spaces, places, connections (Burlington: Ashgate Publishers, 2011) 181; Michael Peter Smith, 'Can you imagine? Transnational migration and the globalization of grassroot politics', Social Text 39 (1994), 15-33, there 17, 18.

9 Grell, Brethren in Christ, 307; Grell, 'The creation of a transnational, Calvinist network and its significance for Calvinist identity and interaction in early modern Europe', European Review of History 16 (2009), 619-636. 
All the families studied in this chapter belonged to the higher social strata and some even to the economic elite of their host societies. As has been argued by scholars on early modern migration in the Netherlands, the social integration of Southern Netherlandish migrants in the Dutch Republic started in the lower social strata, while migrants from the elite stayed relatively long within their own circles and intermarried with fellow southerners. Niek $\mathrm{Al}$ and Clé Lesger even postulated a process of 'integration from below'. ${ }^{10}$ Though there is much evidence that endogamy was practiced longer in the migrant elite circles than in the lower strata in society, I will argue that the rich and well-educated families were no less integrated because they married within their own group for a longer period. In fact, the relationship between the practice of endogamy and the preservation of the feeling of belonging to the diaspora is far from straightforward. As the following cases suggest, the practice of ex- or endogamy may actually not be such a good indicator of the degree of identification with the new host society or the lost homelands.

\section{Reinventing Family History}

Many of the refugees who had left the Southern Netherlands during the early revolt against the Habsburg government in the 1560 s and 70 s and after the capitulation of the important rebel towns of Antwerp, Ghent and Brussels between 1580 and 1585 saw their exile as only a transitory period after which they would be able to return home. Many roamed through the German Protestant territories, the Northern Netherlandish Provinces and Britain and were hopeful that the military campaigns under Stadholder Maurice of Orange would lead to the eventual downfall of Habsburg rule in the south. Family letters of southern migrants from the late sixteenth century are full of expressions of nostalgia and homesickness. Antwerp merchant Johan Thijs, who had fled Antwerp for Holland, frequently wrote to his brother-in-law Andreas de Bacher that he longed for a reunion of the family in what he called 'the Promised Land'. ${ }^{11}$ Until the first years of the seventeenth century he remained full of hope for a future in the

\footnotetext{
10 Niek Al and Clé Lesger, 'Twee volken besloten binnen Amstels wallen'? Antwerpse migranten in Amsterdam omstreeks 1590', Tijdschrift voor Sociale Geschiedenis 21 (1995), 129-144, there 140 .

11 Archief vande familie Thysius, Leiden University Library (Arch. Thys.), 133: C3: Brieven aan Andreas de Bacher. January 26, 1606.
} 
fatherland. In 1599, he reasoned that the Spanish enemies had pushed their luck too far and that defeat was at hand, which would enable his family to return:

Our hope is, that the war, which has endured for so long now, will soon be over and that at last we can return to Antwerp, the city of our fathers. Because the haughtiness of the Spaniard has already reached its climax and it seems, that he who has afflicted all the world, is afflicted himself and that he has suffered harm and mockery, not only at Schenckenschans, but also in Nijmegen. ${ }^{12}$

When the military campaigns of the Republic failed to recapture the Southern Habsburg territories in the first years of the seventeenth century, it occurred to Thijs that exile was not a temporary situation and that his future now lay in Holland. By early 16o6, he had lost hope:

But now I am in doubt and I start to question the (possibility of a coming) peace. Therefore I have resolved to buy a house here and to forget Antwerp. ${ }^{13}$

While in the previous years Thijs' correspondence with his relatives had been full of references to a future in Antwerp and his longing to return, this letter seems to mark a definite end to his hopes. From 1606 onwards his writings are devoid of any mentions of the past. Many fellow-exiles of his generation seem to have fallen into silence about their past and often tried to forget it.

In many cases, it was only in the next generations that individual family members tried to reconstruct their family history and attempted to preserve what they could of the exile past of their forefathers. We can, for example, observe this phenomenon in the case of the Van der Muelen family. In the late seventeenth century, Willem van der Muelen, greatgrandson of former Antwerp alderman Andries van der Meulen, who had left his hometown for Holland, recorded what he could remember of family stories. He also eagerly collected material evidence of his ancestor's refugee past, such as a letter of recommendation by the rebel government of Antwerp, to which he added that his great-grandfather had always behaved as a good patrician and remained loyal to the cause, which forced him to leave his hometown. ${ }^{14}$

12 Arch. Thys. 133: B1: Brieven aan Andreas de Bacher. July 13, 1599. All translations into English are by the author.

13 Arch. Thys. 133: B2: Brieven aan Andreas de Bacher. April 20, 1601.

14 Het Utrechts Archief, 57, inv. nr. 27; 59. 
The family's engagement with its own past had first become manifest in the second generation after the migration to the Dutch Republic: Andries van der Muelen the Younger, Willem's grandfather, was deeply concerned with proving that the Van der Muelens were descendants of a Southern-Netherlandish nobleman who had served the King of France in the eleventh century. In the 1640's he corresponded frequently with his relatives to gather more information about the assumed noble descent of his family and even changed his name from Van der Meulen to Van der Muelen, when his genealogical studies seemed to suggest that this spelling would be more correct. ${ }^{15}$ In addition to this assumed connection to a noble family it was the family's fate of having fled the south for the sake of the Reformed faith that interested him. In $165^{\circ}$ he asked Nicolas de Malapert, a friend of his parents from their time in Antwerp, to sign an affidavit that his parents had left Antwerp in 1585, immediately after the siege of Parma, although the city's Protestant inhabitants had been granted a four-year grace period in which to settle their affairs before the mandatory obligation to convert to Catholicism went into force. By doing so, he could prove that they had been uncompromising Protestants, unwilling to live under the new Habsburg Catholic regime. He also wrote down the story of his uncle Jan van der Meulen who had lost his life defending his hometown during the 'Spanish Fury', a devastating mutiny of Habsburg soldiers in $1576 .{ }^{16}$

In the case the Martens family, also from Antwerp, the same pattern is recognisable. Within the circle of this family a wide range of sources was transmitted to future generations in which the family history was not only preserved but also frequently rewritten. I have studied about ten different manuscripts that heavily borrow from each other, and by comparing handwritings and textual structures I was able to reconstruct how the family memories in the Martens family evolved over time and how the history of the family was rewritten by the various generations.

Very much like Andries van der Meulen the Elder and Johan Thijs, Hans Martens did not leave much information about his flight from the south, although later sources suggest that he sometimes talked to his children about their family's past. ${ }^{17}$ The only notes he left were in tabular form and concerned the births of his children, his marriage and business. Hans' son,

\footnotetext{
15 Ibid., inv. nr. $5^{8 .}$

16 Ibid., inv. nr. 3 .

17 Het Utrechts Archief, 1002, inv. nr. 1.1.
} 
Carel Martens, was an ambitious youth, who was so eager to enter the elite networks of Holland and Utrecht that he went to the Synod of Holland as a seventeen-year-old and asked everyone he thought important enough to write in his album amicorum. ${ }^{18}$ We can find Francis Gomarus, Gisbert Voetius and other famous Counter-Remonstrant theologians in the book but also various members of the Nassau family and poets and scholars like Daniel Heinsius. Carel not only copied his father's autobiographical notes but added a more detailed biographical description and tried to find out as much as he could about his family's past. ${ }^{19}$ In 1633 , he invited his uncle Jacques Martens to Utrecht to confer with his half-brother Hans and to write down everything they recalled about their ancestors. When his son Jacob married Aletta Pater, a girl from a highly influential Utrecht family, Carel and his wife Jacoba Lampsins, also from a rich southern family, commissioned four paintings by Ferdinand Bol, which, according to art historian Margriet van Eikema-Hommes, symbolically represented the entrance of an exiled family into the established elite of Utrecht. ${ }^{20}$ All the four paintings showed well-known Biblical and classical foreigners and exiles, such as Aeneas, Moses, Abraham and the people of Israel in Babylonian captivity. In the paintings the depicted exiles are presented as victors, who despite the hardships of exile had been successful in creating a new genealogy. Like Aeneas, the Martens and Lampsins families had founded a New Troy, and like Abraham and Moses they were bound for the 'promised land' and fathered a new generation of godly people. Just as with the La Mottes in England, the dissemination of the exile narrative could improve their status among the elite circles of Reformed orthodoxy. ${ }^{21}$

Jacob, Hans Martens' grandson, put his family's history into a more structured narrative form and wrote it down in a 'memorie boeck' of which there are numerous copies extant. ${ }^{22} \mathrm{Jacob}$ took the notes of his father and grandfather and complemented them with things he knew from family stories, such as the exact places where his great-grandparents in Antwerp were buried. The actual narrative 'plot' begins with the migration of Hans and his siblings in the period of the very early Revolt:

18 Ibid., inv. nr. 40.

19 Ibid., inv. nr. 60.

20 Margriet van Eikema Hommes, Art and allegiance in the Dutch Golden Age. The ambitions of a wealthy widow in a painted chamber by Ferdinand Bol (Amsterdam: Amsterdam University Press, 2012), 151ff.

21 Ibid., 165.

22 Het Utrechts Archief, 1002 inv. nr. 1.1-4. 
The children of Francoys Martens fled to Amsterdam for religion's sake under the Spanish persecution and were separated from each other during the reign of the Princess of Parma as well as the persecution of the duke of Alba $[\ldots] .^{23}$

Even though Hans Martens' considerably older brothers were already young adults in the time of Margaret of Parma, Hans himself was born in 1555 and only twelve years old when Margaret resigned and was replaced by the duke of Alba. His notes show that Jacob was in doubt about the date when his grandfather had left Antwerp:

Hans Martens fled Antwerp for religion's sake during the troubles under the duke of Alba in the year... [lacuna] and left for Amsterdam with some of his brothers and sisters, where he settled down in silence as a merchant. Through the persecutions he had become a devout and godly man, who did not care about the grandeur of the world and and because he wanted to avoid prestige, he refused to use his family's coat of arms $[\ldots]{ }^{24}$

The lacuna in the text about the year of Hans Martens' flight from Antwerp can be found in all existing manuscripts. Obviously, the regimes of Margaret of Parma and Alba were so central to the collective memory of Dutch Protestantism that in the oral tradition things became mixed up. It is, however, rather unlikely that the young teenager Hans had indeed left his hometown as early as the 1560 s when his parents still lived in Antwerp. The first records of his existence in Amsterdam date from the early 1580s, a time when Antwerp was still in rebel hands.

At the time of Jacob's marriage the Martens family had already entered the Reformed elite of Utrecht, and the story of the grandfather, who 'did not care about the grandeur and the haughtiness of the world' and had become a 'devout and godly man' in and through exile fitted well into the circles of orthodox Reformed Utrecht in the era of Gisbert Voetius, the leading light of the 'Further Reformation' movement. Nevertheless this narrative also had a problematic aspect. The earliest versions of the manuscripts read:

[Hans Martens] has always said to his children that he descended from the best and finest families of Antwerp, but that he had learned through the persecution to hold in disdain the grandeur of old families and to keep himself quiet and humble and therefore refused to use his coat of arms which could be found everywhere among his popish family in Antwerp. ${ }^{25}$

\footnotetext{
23 Ibid., 1002, inv. nr. 1.2.

24 Ibid., inv. nr. 2.

25 Ibid.
} 
At the time when the story was written down, the Martens family were themselves acting like an 'old family' and had become conscious of their family and dynastic identity. And, of course, Jacob himself already realised the inconsistency of this narrative. In later manuscripts he changed the text and crossed out all the passages about Hans' contempt 'for old and famous families'. The phrase 'He had learned through the persecution to hold in disdain the grandeur of old families' was from then on erased and replaced with: '[...] the persecutions taught him to forget his ancestry.'26

While families like the La Mottes in England and the Martens family in the Dutch Republic represented their past in terms of godliness and confessional steadfastness when entering Puritan and orthodox Reformed networks, others deployed discourses of patriotism and national consciousness to establish their position in their host societies. The members of the wealthy Panhuys family, whose forefathers had also fled Antwerp, not only invented a noble lineage for their ancestors but also strongly emphasised the notion of their common Netherlandish ancestry that united them with their neighbours. While most of their ancestors originally came from Limburg and the region around Trier and Liège, they had established themselves in the elite merchant circles of Antwerp during the sixteenth century. In their family chronicle they introduced the history of their bloodline with an account about the ancient Batavians who were praised by Tacitus and from whom the Netherlanders descended. ${ }^{27}$ The Batavian past was a popular motive in the historical discourse in seventeenth-century Holland, though the actual geographical origin of the Batavians was disputed by the various provinces of the Netherlands, which claimed to be descendants of this legendary Germanic tribe. These disputes are not mentioned in the Panhuys chronicle and a common Netherlandish origin is evoked: the ancient Low Countries are portrayed as stretching from the Meuse region to Northern France and even the French noble house of Capet is included into the list of old Netherlandish noble families. By appealing to the patriotic feelings of the inhabitants of the Dutch Republic, the Panhuys family tried to evoke a connection between themselves as migrants and the elites in their new hometowns Amsterdam and Utrecht. Even though their claims of descending from nobles were often disputed during the seventeenth century, they were able to enter the elite circles of the Dutch Republic. For centuries, the

26 Ibid., inv. nr. 1.3; 1.4 .

27 Regionaal Archief Leiden, LB 6331, Cort verhael van het out ende adelijck geslachte van Panhuijs, afcomstich uut den lande ende vorstendom van Limburg, 1270-1817, f. 5r. 
emphasis on their Netherlandishness and their 'natural' bonds with their neighbours in the North remained a crucial element of the tale the family told about its own history. When the family was at last officially admitted to the nobility in the new Kingdom of the Netherlands in the nineteenth century, the family chronicles were extended and the Panhuyses presented as an old and well-established Dutch family. ${ }^{28}$

\section{Permeable Memories}

The cases of the family histories of the Martenses, the Van der Muelens and many other southern families in the Republic show how memories were preserved long after the time that their descendants had married into local families and had begun to participate in local politics and cultural life. While exile narratives had initially emphasised the migrants' status as strangers who hoped for a return to their homeland, from the second generation onwards their character and function changed: instead of stressing the differences between strangers and locals, the memory of an exile past could help the children of the refugees to build ties with the networks of the local host societies. Stories of exile and suffering served as a narrative of origin that legitimised the status of the migrant families as homines novi. The mists which had settled over some family origins before the time of migration could be seized upon to claim a higher social status: since the family was not known in the host society, stories about noble descent could hardly be disproved. At the same time the assertion that the ancestors had been so godly and pious that they had avoided any identification with their popish relatives and therefore denied their ancestry could be also be appealing to the religious elites of their new homes.

Instead of forming exclusive 'memory ghettos', migrant families such as these therefore developed memory cultures that did not separate them from the discourses and narratives of their host societies but in fact proved highly permeable. Migrant families easily combined their own exile narratives with religious and political discourses of their host societies, such as the hospitality towards their ancestors under Queen Elizabeth and her restoration of Protestantism in England or the narrative of the struggle against the Spanish oppressors in the Dutch Republic. The imagined diaspora of the numerous refugee families from the Southern Netherlands

28 Ibid. 
should therefore not be understood as a dividing line between locals and strangers. It was not despite, but rather because of, the commemoration of their immigrant background that these families were able to enter local networks and attain a higher social status in their host society. Becoming Dutch, English or German did not imply oblivion of the diaspora past and the identification with the local society could perfectly be combined with the cultivation and reinvention of the exile narrative and identity.

These findings also carry some important methodological implications. While migrant diasporas are often understood as producing an exclusive form of identification with their own group, endogamy and the transmission of traditions and memories are often used as the most important indicators of the degree to which the diaspora is still extant. ${ }^{29}$ However, as I hope to have shown, the notion of a transnational diaspora does not have to be diminished by the strengthening ties of the individual migrants with their host societies. In migration studies, a diaspora should therefore not be conceived of as something which is extractable from a given set of data on marriage patterns or social and economic behavior but rather as a horizon of belonging and identification which may be expressed only occasionally and which does not have to conflict with the loyalties migrants feel towards the communities where they reside. As the cases of the La Motte, Martens or Van der Meulen families show, the opposite development could also occur: remembering exile strengthened their feeling of belonging to their host society. Being Protestant, being English or Dutch and descending from an exiled family were identities so closely welded together that they were sometimes no longer detachable from each other.

29 See e.g.: $\mathrm{Al}$ and Lesger, 'Twee volken besloten binnen Amstels wallen'?; Gerard van Gurp, 'Bosschenaars in de verstrooiing. Emigratie tussen 1579 en 1629', Tijdschrift voor Sociale Geschiedenis 23, nr. 4 (1997), 401-427, there 420ff.; Leo Adriaenssen, 'De brabantisering van Haarlem in 1579-1609', Noordbrabants historisch Jaarboek, 24 (2007), 102-135, there $120 f f$. 
Erika Kuijpers, Judith Pollmann, Johannes Müller, and Jasper van der Steen - 978-90-04-26125-9 Downloaded from Brill.com04/26/2023 11:57:20AM via free access 
CHAPTER SIXTEEN

\title{
WOMEN, MEMORY AND FAMILY HISTORY \\ IN SEVENTEENTH-CENTURY ENGLAND**
}

\author{
Katharine Hodgkin
}

History, broadly conceived as the recording and preserving of knowledge of the past, is one of the oldest and most universal of disciplines. The terrain of the historical, however, is less stable: what kinds of knowledge are perceived as valuable, what questions are worth asking, what records are worth keeping, are all subject to transformation. The seventeenth century was a period when history, along with much else, was in transition, with new boundaries emerging alongside new professional practitioners of the discipline. The wide range of genres potentially encompassed by earlier understandings of history-chronologies, accounts of political and military events, individual lives and family pedigrees, localities and antiquities, even fictional and poetic accounts of the past-was under pressure from an increasingly self-aware and assertive body of writers keen to establish new hierarchies of knowledge. By the end of the century a familiar version of the historical was emerging as dominant, one which valorised the political and the military, while downgrading antiquarianism and family history as of merely local interest. ${ }^{1}$ Proper history, increasingly, addressed itself to the public world.

This was also, to a great extent, history not only about but written by men. In so far as history is a written discipline, of course, women's participation in it has always been limited, as their levels of literacy and access

* This paper has been through a number of versions and presentations over a number of years, and I am grateful to many readers and listeners for their comments and suggestions. Particular thanks to Laura Gowing, for perceptively critical comments on an early version as well as for responses to a later iteration when I gave the paper at the Institute for Historical Research in London; to Judith Pollmann and Erika Kuijpers, both as conference organisers and for light-touch but very astute editorial comments; and especially to Jeni Williams for a characteristically brilliant and constructive critique at a crucial moment in rewriting.

1 The timing of this shift is debated. Daniel Woolf argues that the new hierarchy was well-established by the mid-seventeenth century, although definitions of 'history' remained unstable: Daniel Woolf, The social circulation of the past. English historical culture 1500-1730 (Oxford: Oxford University Press, 2003). 
to education were lower. Seldom taught Latin, and with little access to the archives and muniment rooms where records were stowed, women were restricted in their ability to engage in direct archival research or to write scholarly histories of public events. ${ }^{2}$ The tightening of the boundaries of history in this period also defined as non-historical many of the ways in which the less formally educated — men as well as women — might engage with the past. Much of what was excluded by the new history of the seventeenth century, indeed, would today be understood as memory rather than history: oral traditions, family history, local lore. The pre-modern oral cultures through which community knowledge and stories were transmitted were also memory cultures, in which women often played an important part. Recollecting the floods or land disputes of fifty years earlier, or the complex sequence of intermarriages shaping kinship networks and determining inheritance rights; telling stories or ballads passed down through generations of great events beyond living memory, or myths explaining the features of local topography; such elements contributed to a shared memory culture which in the course of the sixteenth and seventeenth centuries, was increasingly discounted as knowledge. The association of local memory with women further devalued it; the old wives' tale figured as the superstitious and unreliable opposite of the new empirical history. ${ }^{3}$

But despite the long dominance of this professionalised academic history, the boundary between history and memory remains a porous one; the delimitation of the historical is always problematic, and its terms and limits are constantly revisited. Family history in particular highlights the instability of the memory/ history boundary. As a private and domestic form of knowledge, focused on family relationships, often transmitted orally, and important above all for its immediate resonance and meaning

2 Natalie Zemon Davis discusses the obstacles to women researching and writing history, and critiques the "hierarchy of genres, in which general or national history is at the top': Natalie Zemon Davis, 'Gender and genre: women as historical writers, $1400-1820$ ', in Patricia Labalme (ed.), Beyond their sex. Learned women of the European past ([1980], New York: New York University Press, 1984) 174. Megan Matchinske argues that seventeenthcentury constructions of the past reveal 'the uneasy relationship between a masculinist history just coming into its own and the host of unacknowledged and extra-disciplinary discursive forms surrounding it', suggesting that we need a broader definition of history to engage with women's historical writing: Megan Matchinske, Women writing history in early modern England (Cambridge: Cambridge University Press, 2009), 2, 1. See also Daniel Woolf, 'A feminine past? Gender, genre and historical knowledge in England, 1500-1800', American Historical Review 102: 3 (1997) 645-679.

3 See Adam Fox, Oral and literate culture in England 1500-1700 (Oxford: Oxford University Press, 2000), 176, and on women and oral culture see chpt. 3 . 
to those alive, family history can helpfully be understood as a memory practice. But at the same time, the gathering and transmission of knowledge about the past is central to the process of constructing a family history, involving research, recapitulation, and a sense of the place of individuals and families in the wider world. It is also an activity often associated with women. ${ }^{4}$ The accounts I discuss in this paper, family histories by gentry women, are (like so much seventeenth-century personal writing) generically mixed and complicated; but all of them involve some kind of recourse to the past, and draw on knowledge of periods and people outside the direct experience of the writer. Embedding their own stories and those of their husbands in accounts of previous generations, and shaping the narrative of the past out of memories and anecdotes as well as archives, these women position themselves in a relation of past and future that implies a historical perspective on their own lives. While they do not generally refer to their work as 'history', their stories engage with a broader concept of the historical than the notion of 'family history' as private might allow, unsettling the relation of memory and history; and a more inclusive understanding of the historical may allow us to recognise the diverse ways in which women in this period (as well as men) remembered and engaged with the past.

\section{Women and Genealogy}

Family history, emerging as a popular interest in Britain in the course of the sixteenth and seventeenth centuries, drew in a great variety of people: men and women at many different levels of society were keen to record and transmit their family stories. ${ }^{5}$ But for the gentry in particular, genealogy was highly significant. ${ }^{6}$ Both established and aspirant gentry families affirmed their status through the construction and reconstruction of family trees, connected ideally to continuous possession of land, displaying connections to prominent families, and asserting the merits and gentility of progenitors; and women, as zealous in the pursuit of

\footnotetext{
4 See Woolf, Social circulation, 116-117; Davis, 'Gender and genre', 161-162. Davis also looks briefly at differences between family histories written by men and by women.

${ }^{5}$ See Natalie Zemon Davis, 'Ghosts, kin and progeny. Some features of family life in early modern France', Daedalus 106.2 (1977), 87-114.

${ }^{6}$ On gentry interest in genealogy see Woolf, Social circulation, esp. chpt. 3; Jan Broadway, 'No historie so meete.' Gentry culture and the development of local history in Elizabethan and early Stuart England (Manchester: Manchester University Press, 2006).
} 
pedigree as men, increasingly became family genealogists, remembering and recording the familial and domestic past. The appropriateness of this in many ways seemed self-evident. Family was a woman's domain, and family remembrance an act of piety to the dead. The 'private' space of family history, tangential to the grand sweep of public affairs, was a territory in which women might legitimately operate-'particular history' as Margaret Cavendish called it; a place of memory, rather than of history, in a more recent idiom. ${ }^{7}$ However, as many writers have noted, the division between private and public, which locates 'family history' in the private sphere, is inadequate as a tool for understanding either family or history in this period. ${ }^{8}$ Family, both materially and ideologically, was a matter of public and political concern, even when rhetorically positioned as private. As microcosm of the state and exemplar of godly order, the family was not a private space, any more than marriage and childrearing, through which wealth, property and power are channelled, were purely domestic and intimate affairs-especially for the landowning classes. Gentry family history describes among other things the positioning of powerful family groups on a shifting political ground, and genealogies in the seventeenth century register those political shifts and transformations, as family fortunes rise and fall.

Family stories thus summon up the gentry past of reputable forebears in the context of wider historical and temporal transformations, locating the self within both lineage and national stories; different temporalities and histories shape the relation between past and future articulated in these accounts. When seventeenth-century family historians-women and men-mark the importance of lineage by locating their stories in a longer historical narrative, they construct a self in which family and history overlap — as Daniel Woolf describes it, a 'personal historical domain'. ${ }^{9}$ This paper explores the nature of that personal domain in the writings of three seventeenth-century gentry women-Anne Clifford, Lucy Hutchinson, and Anne Fanshawe. The term 'gentry' here of course masks substantial differences. Anne Clifford, descendant of earls on both sides, married to another, and frequenting the courts of kings, was a member of the

7 Cavendish is quoted and discussed by Davis, 'Gender and genre', 163-165.

8 On conceptions of private and public in relation to women's political and literary activities see Susan Wiseman, Conspiracy and virtue. Women, writing and politics in seventeenth-century England (Oxford: Oxford University Press, 2006).

9 Woolf, Social circulation, 117 . Woolf uses the phrase specifically of women, presumably because they are restricted in their ability to construct other, more extensive historical domains. 
aristocratic elite even before she inherited the vast estates which would make her one of the most powerful landowners in the country; Anne Fanshawe was a woman of rank, married to a baronet who was an ambassador under Charles II; Lucy Hutchinson, although (as she was keen to point out) well-bred, had neither title nor any strong connection to the royal courts. But the word also reminds us of what they share, in their concern to assert two important elements of gentry prestige: lineage and connection to place. Not all gentry families were in a position to claim such pedigrees, of course (though some might invent them), and the lack of lineage was no serious bar to status or influence. Nonetheless the deployment of family history in these women's writings is a reminder both of its cultural importance and also of its mobility as a cultural signifier; the meaning of lineage is shaped by a range of social and personal factors, from gender and political affiliation to intimate family relationships, births and deaths.

The question of what history and what family constitutes one's personal historical domain is thus not transparent, especially for women, whose relation to lineage is by definition oblique. Lineage traces not merely antiquity, but antiquity in the male line; blood, in the lineage sense, is male blood. An old family is one in which generations of sons have lived to beget more sons; a family that begets only daughters will shortly be defined as extinct. Sons inherit the property that secures continuity in one place; they not only inherit but transmit to their own children the family name. ${ }^{10}$ Wives, as the early seventeenth-century guide The Lawes Resolutions of Women's Rights explains, have no legal identity: 'When a small brooke or little river incorporateth with Rhodanus, Humber or the Thames, the poore Rivolet loseth her name... it beareth no sway, it possesseth nothing...'11 Women are the bearers of lineage, not its possessors; their birth identities are subsumed in their marital identities. This suggests that women's investment in genealogy should not be taken for granted: why dedicate your energies to the maintenance of a family history from which you are excluded? Another perspective, however, might suggest that women have more options than men in identifying their families, and that their early prominence in the field of family history may reflect

10 Women did of course have some property rights in English law; widows and single women could own both land and money, and wives could retain rights over their own property subject to legal agreements. See Amy Erickson, Women and property in early modern England (London: Taylor \& Francis, 1993).

11 T.E., The Lawes Resolution of Womens Rights (London, 1632), 124. 
not only their more domestic preoccupations but also their less fixed possession of family identity. Genealogically speaking, they may belong to birth or marriage family; they may focus on maternal or paternal pedigree. And if women have a choice about what their family history is to be, their diverse engagements with lineage, history and posterity raise questions about how they position themselves in their families, and in time and history more generally.

For Anne Clifford (1590-1676) the paternal inheritance, literal and symbolic, is of paramount importance, and her assertion of her claim to place in her family (as heir of her father's lands) is supported by the extensive genealogical investigations recorded in her 'Great Book', as well as by her diaries and memoirs; having eventually succeeded in her claim, she spent her last decades ruling over the lands of her inheritance in the north, distanced from political upheaval. For the other two writers considered here, by contrast, the Civil War is the defining event of their lives. Anne Fanshawe (1625-80), the widow of a royalist baronet, wrote a long account of her life with him, prefaced by an account of his family history, for the information of her only surviving son; while on the other side of the Civil War Lucy Hutchinson (1620-81) wrote a life of her husband, the Parliamentarian governor of Nottingham Castle, similarly intended to inform her children about their dead father and his family history as well as her own lineage and upbringing. ${ }^{12}$ Their narratives are constructed in the context of inheritance disrupted and stability lost, and the family past is summoned up to assert continuity despite these challenges.

In their writings these women can be seen as keepers of family memory, transmitting the past through the present for the use of the future. But they also share a troubled and melancholic relation to that future,

12 For Anne Clifford's journals see D.J.H. Clifford, The diaries of Lady Anne Clifford (Stroud: Alan Sutton Publishing, 1990). See also, The diary of Anne Clifford, 1616-19. A critical edition, ed. Katherine Acheson (New York: Garland, 1995). Clifford's Great Book of family history and genealogy is transcribed in Hilda Smith, Mihoko Suzuki and Susan Wiseman (eds.), Women's political writings, 1610-1725 (London: Pickering and Chatto, 2007), vol. 1. Anne Fanshawe's narrative is published in John Loftis (ed.), The memoirs of Anne, Lady Halkett and Ann, Lady Fanshawe (Oxford: Clarendon Press, 1979). For Lucy Hutchinson's memoirs of herself and her husband see Neil H. Keeble (ed.), Memoirs of the life of Colonel Hutchinson (London: Phoenix Press, 2000). There is an extensive body of scholarship on these writers. Among works focusing on history and memory, see e.g. Mary Beth Rose, 'Gender, genre, and history. Seventeenth-century English women and the art of autobiography', in Rose (ed.), Women in the Middle Ages and the Renaissance. Literary and history perspectives (Syracuse, NY: Syracuse University Press, 1986); Kate Chedgzoy, Women's writing in the British Atlantic world. Memory, place and history, 1550-170o (Cambridge: Cambridge University Press, 2007); Matchinske, Women writing history. 
governed by loss_ - of husbands, of land, of children and grandchildren. Family history may assert ideals of continuity and stability, but war, displacement and mortality constantly threaten those ideals. History and memory both must deal with conflicts, alliances, gain and loss, and the family cannot be isolated from politics. Anne Clifford's account of her long struggle with husbands, courts and king to inherit the vast properties of her father's estate is no less political than Lucy Hutchinson's analysis of the causes of the Civil War; Anne Fanshawe's narrative excludes politics as a topic of address, but the story she tells is determined by the royalist affiliations of her husband. The choices these writers make about what to commemorate, and the sources they draw on to construct their accounts of the past, show the making of family memory as an active and creative process. Rather than a site of patriarchal piety, in which dutiful wives and daughters preserve and memorialise approved lineages for future generations, family history is a complex and shifting territory, invoking contradictory loyalties, bringing memory into play alongside history, and the future alongside the past.

\section{Remembering the Past: Lineage and History}

Anne Clifford's life, with its dramatic shifts of fortune and positioning and its exceptionally extensive archive, has made her an iconic figure in the study of early modern women's lives and writing. ${ }^{13}$ More than any other woman of the period, her life's work is defined by her struggle over what she did and did not inherit from her birth family. Passed over in the will of her father, the Earl of Cumberland, in favour of his brother as heir of both lands and titles, she fought unsuccessfully for many years to overturn the will, outliving two husbands in two not very happy marriages, and finally inheriting her father's properties following the deaths of her uncle and cousin. Clifford's long battle to assert her rights against husband, king and uncle can invite a reading of her life as one of struggle against patriarchal authority; but this is counterbalanced by her uncompromising identification with her paternal lineage and with aristocratic power. ${ }^{14}$ Her memorial

13 Mihoko Suzuki (ed.), Anne Clifford and Lucy Hutchinson (Burlington, VT: Ashgate, 2009), gives a selection of the most influential essays. See also Matchinske, Women writing history, chpt. 4. Chedgzoy, Women's writing, discusses Clifford's life and writings in relation to memory.

14 See for example Barbara K. Lewalski, 'Re-writing patriarchy and patronage. Margaret Clifford, Anne Clifford and Aemilia Lanyer', The Yearbook of English Studies 21 (1991) 
and genealogical activities in a sense articulate these contradictions: her overriding aim is to assert herself as the true heir of her father, and she takes little interest in her maternal lineage (despite her mother's importance in her life) and even less in her marital families. She is a Clifford, and the centrality of this to her identity does not admit other blood..$^{15}$

Clifford's indifference to the lineage of her first husband, the Earl of Dorset, is perhaps surprising, given that it relates not only to herself but to her daughters. Since her two surviving children were female, her husband's title and estate, like her father's, went to his brother; their situation thus mirrored her own, confirming the exclusion of the daughter from the father's inheritance. But whereas her response to this situation in her own life was ferocious denial, legal contestation, and detailed genealogical reconstruction of her paternal lineage, she made no claim on the Sackville inheritance on behalf of her daughters; she seems simply to have written their father out of their life, identifying them instead as the wives of their husbands and the heirs of her family, and their children as eventual inheritors of the Clifford line. Clifford's historical domain is centred on herself, and variously matrilineal or patrilineal according to context. Her formal record of genealogy, the Great Book, gives priority to the male pedigree, though inserting women into it as legitimate heirs. But her positioning of her own children and grandchildren offers a more ambiguous genealogy, in which paternal blood is displaced by maternal, and by marriage.

Clifford's preoccupation with lineage might imply a sense of time as linear; but in both her writings and her life, history seems to be governed by repetition rather than by progress, and by an urge to undo the changes of linear history. She lives in a time structured by repetition and recurrence, cyclically connecting her to the near and the distant past. ${ }^{16}$

87-106; Mary Ellen Lamb, 'The agency of the split subject: Lady Anne Clifford and the uses of reading', ELR 22 (1992) 347-368; Mihoko Suzuki, 'Anne Clifford and the gendering of history', Clio 30 (2001) 195-229.

15 On Clifford's maternal family see Lewalski, 'Re-writing patriarchy'. Stephen Orgel notes that after marrying the Earl of Pembroke she signed herself Anne Pembroke, implying at least some identification with the title: Stephen Orgel, 'Marginal maternity. Reading Lady Anne Clifford's A Mirror for Magistrates', in Douglas A. Brooks (ed.), Printing and parenting in early modern England (Aldershot: Ashgate, 2005) 267-289.

16 Debates over culturally variant temporalities, both in relation to gender and to modernity, are too large to address here, but see the discussion of time and autobiography in Ronald Bedford and Philippa Kelly, Early modern English lives. Autobiography and selfrepresentation 1500-1660 (Aldershot: Ashgate, 2007). For a discussion of cyclical and linear time in relation to memory and ritual, see Stephan Feuchtwang, 'Ritual and memory', in Susannah Radstone and Bill Schwarz (eds.), Memory. History, theories, debates (New York: Fordham University Press, 2010). 
Her later years were dedicated to the building of both stone and written monuments commemorating her progenitors, and to repairing the castles abandoned by her ancestors and ravaged by the passage of time. ${ }^{17}$ Her historical reference points mingle monarchs, ancestors, wars and rebellions ('since one thousand five hundred sixtie nyne, a little before the death of my Grandfather of Cumberland, when the roof was pulled down in the great Rebellion time in that March ...'), affirming the continuity of family and place. ${ }^{18}$ Repetition and recurrence also govern her personal memories. In the diary of the last few months of her life, she recalls the events of her youth, day by day: 'I remembered how this day was 59 years my first Lord \& I \& our first child the Lady Margaret went out of Great Dorset House in London towne to Knowl house in Kent ...'19 Events, in Lady Anne's inner calendar, do not happen only once; they are repeated, remembered and relived on an annual basis. The insistent patterns of cyclical remembrance suggest it was habitual with her to live in a merging of temporalities, erasing the difference between past, present and future. Rather than seeing the Clifford family story, or her own life within it, as one of rise and fall, she represents it as one in which she repeats and remains in place, both in her own remembered life and in that of her ancestors.

Fanshawe in certain ways shares this time of cyclical repetition; but for her the stability of place has been disrupted, and her account of lineage can be seen as an attempt to repair the breaches of war. Her single volume of memoirs, addressed to her only surviving son, is designed to tell him about 'the most remarkable actions and accidents of your family, as well as those of more eminent ones of your father and my life'. ${ }^{20}$ Her narrative of her son's paternal lineage begins with his great-grandfather, who rose to prosperity in the reign of Henry VIII, detailing marriages, and the associated financial transactions; children born and children surviving; cousins, especially in the eldest branch of the family; characters of long-dead relatives ('a very worthy, valiant, honest, good natured gentleman ... yet cholerick and rash'; 'a very good wife, but not else qualified extraordinary in anything'). ${ }^{21}$ She barely mentions her own birth family - unlike Clifford, she has identified herself completely with the marriage lineage. What she transmits to her son is his patrilineal inheritance, and along with it his

17 On building as an act of memory see Chedgzoy, Women's writing, 16.

18 Clifford, Diaries, 110.

19 Ibid., 234.

20 Fanshawe, Memoirs, 102.

21 Ibid., 106. 
potential allies, supporters and friends. Standing in for the absent father, she passes on his family memories not to her daughters but to her son, their rightful inheritor, whose identification with the Fanshawes as 'your family' is uncompromised.

The information Fanshawe records is based on personal knowledge, apparently drawing on oral tradition, in which stories, anecdotes and characters are passed down the generations. Women figure in these family memories as they cannot in pedigree genealogy - in particular for their contribution to the success of the lineage. 'I must here with thankfullness acknowledge God's bounty to your family,' she remarks, 'who hath bestowed most excellent wives on most of them, both in person and fortune' (presumably including herself). ${ }^{22}$ Fanshawe's narrative reinserts women into the story of lineage, on condition that the wives incorporate themselves fully into the family, as she has done. And yet, as her characterisation of the Fanshawes to her son as 'your family' and their wives suggests, however completely she has identified her interests with those of her marriage family, she is not one of them. Like the excellent wives of previous generations, she offers herself and her capacities up to sustain the genealogical enterprise; but she herself remains on the family margins, the place of anecdote rather than inheritance. Her historical world is domestic and familial, constituted by story and memory rather than by written documentation.

Temporality for Anne Fanshawe, too, is above all familial and domestic, linked to place, and repeated through the generations of new wives and children. But in her own life, this temporality might be said to have failed her: the difficulties of Fanshawe's life are political and historical in their causes. Throughout the years of war and Commonwealth she was in exile and constant movement, often separated from her husband, and always short of cash; the Restoration brought rewards, but more travel, on ambassadorial assignments. The public world of politics is thus the frame of her narrative. But it is a frame that remains largely unspoken; Fanshawe's narrative defines her place as strictly bounded. This creates a curious absence of explanation or causality. The war years are repeated flight and loss; the years of peace are an endlessly repeated cycle of grand occasions, spectacular court receptions, gifts and compliments, listed in detail, and interspersed with more losses and deaths. Fanshawe lives in a cyclical and repetitive temporality, in which explanation is superfluous, since she has no power to effect substantial change.

22 Ibid., 107. 
Lucy Hutchinson's narrative could be seen as a mirror of Fanshawe's from the other side of the political divide. Like Fanshawe, she opens with an account of her husband's lineage, although unlike Fanshawe she also describes her own. Hutchinson's family narrative is also constructed from oral sources-family stories and ancient locals—and shaped by anecdote and example, rather than by politics (or even by the iteration of dowries and alliances). Here too, notwithstanding the apparently patrilineal agenda of family history, in her account of her husband's lineage women briefly appear in history. Thus she tells the story of a talented, virtuous and beautiful woman who went mad after a difficult childbirth, but whose husband remained faithful to her in her 'pretty deliration' to the end; the underlying thought here is presumably that men of her husband's kin are loyal husbands, even in desperate circumstances. ${ }^{23}$ She also tells at length the romantic story of her own courtship. In recording these stories Hutchinson, like Fanshawe, is converting memories into histories: reproduced as written text, such anecdotes change the status and meaning of such women in their family histories.

Despite these similarities, however, Hutchinson is a very different figure to Fanshawe, a political and religious radical whose account of her husband's life is primarily a history of the Civil War. While her radicalism does not prevent her from attaching significant value to gentle descent, once she has got through the ancestral stories which declare Colonel Hutchinson's gentility other concerns push the family domain aside. Her story is one of battles, negotiations, deceptions, failures and successes; above all of the great failure of the revolutionary cause with the Restoration. Hutchinson took her role as historian very seriously, offering overviews and analyses of the course of events on a national stage alongside detailed commentaries on the local situation, and the political world is fully present in her narrative. ${ }^{24}$ But alongside her historical narrative, she is wrestling with the question of causality, and in particular God's intent: if providence is behind all events, why did the Commonwealth fail?

To the extent that Hutchinson finds a way of coming to terms with her losses, it is by locating her personal story not just in lineage but in

23 Hutchinson, Memoirs, 35 .

24 On Hutchinson as historian, see David Norbrook, "But a Copie”. Textual Authority and Gender in Editions of "The Life of John Hutchinson”', in William Speed Hill (ed.), New ways of looking at old texts III (Tempe, Arizona: Center for Medieval and Renaissance Studies, 2004) 109-130; Robert Mayer, 'Lucy Hutchinson. A life of writing', Seventeenth Century 22 (2007) 305-335. Hutchinson's main external source is Thomas May, The history of the Parliament of England (London, 1647). 
the larger frame of national and providential history, and in a dynamic and chronological sense of time. In her brief account of her own life, after a historical sweep through the valorous ancient Britons, the stout warlike Saxons, and the violent and deceitful Normans, she places herself in this history, through her father's Saxon descent and her Norman mother. England, in a familiar rhetoric, appears as a specially chosen nation for the working through of God's providential designs-'Whoever considers England will find it no small favour of God to have been made one of its natives' - and English Christianity as of higher quality than anyone else's, 'God having as it were enclosed a people... to serve him with a pure and undefiled worship'. ${ }^{25}$ This providential historical perspective serves to locate her very specifically in time and place: her own lineage is woven together with the history of England, bringing her into existence at a high point of spiritual growth. Her account thus locates the specificities of lineage and gentility in the grand narrative of the nation, both as extended history and as recent political upheaval. Moving between family, historical and providential time, Hutchinson's mixed temporalities offer at least the potential to accept change and defeat as a stage rather than as a final outcome.

\section{Memory and the Future: Continuity and Loss}

Ancestors, in lineage terms, are significant because they have descendants; family history remembers previous generations for the future. Children, above all the sons who are crucial to continuity and transmission, are the linchpin of the family story. This patrilineal urge is registered in Anne Clifford's particular interest in her male descendants, although she could not pass on her father's titles. ${ }^{26}$ In 1659 , with the birth of a grandson and a great-grandson in the same year, she notes, 'this yeare I had the Blessing to have two male children borne into the world of the generation of my Bodie'; both died within eighteen months. ${ }^{27}$ In such remarks Lady Anne may be in part recollecting her four dead sons, none of whom survived beyond infancy. But she is also registering the forces that work against

25 Hutchinson, Memoirs, 5 .

26 Clifford's grandson Nicholas (third Earl of Thanet) claimed the barony of de Clifford after her death, becoming the fifteenth Baron; the title was held by women several times in subsequent generations. However the Earldom of Cumberland became extinct.

27 Clifford, Diaries, 143. 
continuity: families become extinct not least because children die. Year after year, her diaries record the births and deaths of her posterity: she was predeceased by five out of six children, eight out of fifteen grandchildren, seven out of fifteen great-grandchildren.

Clifford's insistent commemoration of the past, in relation to this burden of loss, seems a melancholic mode of memory. Death is the common end of old and young, remote and near relations; daughters and granddaughters grow, give birth and die. Grief at the loss of children, grandchildren and great-grandchildren is also grief at the passage of time and the extinction of families. Thus she records the death of her cousin in the Great Book as a loss for the family, since he was 'the last heir male of that house', and with him died the Earldom, even though it was only through his death that she was able to inherit. ${ }^{28}$ It is paradoxical that this most insistent of family chroniclers should be left to record what is for her the end of her family. But just as she identified herself as the true Clifford heir in defiance of lineage criteria, so she also identified her daughter's sons as continuing that family history. In her later diaries, kept during the decades she lived in the north, the significance of the visits of her descendants is marked as above all the moment when the child or grandchild enters the land of inheritance: 'the first tyme that this first Childe of mine or her Lord or any of mine owne Children came to me into Westmerland, or into any part of ye Lands of mine Auncestors'. ${ }^{29}$ If in relation to her own inheritance she sees her lineage as paternal, as far as her descendants are concerned her focus is almost entirely matrilineal. She herself is the point of transmission through which the great history of her father's family would pass to her daughters and their children-or at any rate their sons-even though the family was formally 'extinct'. ${ }^{30}$

The loss of children also pervades Anne Fanshawe's narrative. Her account of the family history emphasises stability: the bond to place is established by the centuries-old tombs in the family chancel in Ware. In contrast to the geographic stability of the family history, however, the narrative of their marriage is one of constant displacement and travel,

28 Clifford, 'The great book', 105. There is ambivalence here; as Suzuki notes, she refers to the tenure of her uncle and cousin as a 'digression', and describes her lands as 'unjustly detained' by them, Smith et al., Women's political writings, 3 . But the extinction of a title is nonetheless a loss.

29 Clifford, Diaries, 119 .

30 In an irony worth noting, the family tree provided in D.J.H. Clifford's modern edition of the diaries gives the names of all Anne's daughter Margaret's sons, and adds ' 5 daughters', unnamed (Clifford, Diaries, 272). 
accompanied by constant childbirth and death. In the twenty-three years of their marriage, Lady Fanshawe gave birth to fourteen children, and miscarried a further six (including triplets). By the time of Sir Richard's death nine of these children had died. Throughout the narrative travel is complicated by pregnancy or lying in; she gives birth in random places, leaves infants with wetnurses to be retrieved later, buries them where they die, moves on. Fanshawe seldom dwells on the emotional impact of these losses. Only one death leads her to record deep emotion, that of a daughter who died at nine, of whom she says briefly, 'We both wished to have gone into the grave with her'. ${ }^{31}$ The son who dies of smallpox even though she neglects his two sick sisters to nurse him also elicits sorrow, in rather shocking terms: 'it pleased God they recovered and he dyed, the grief of which made me miscarry $[\ldots]^{3}{ }^{32}$ These deaths offer an uncanny parallel to the importance attaching to place in Fanshawe's account of lineage. Counterbalancing the various family members who lie "buried with their ancestors' she enumerates the burial places of her children:

My eldest daughter Ann lyes buried in the parish church of Tankersley in Yorkshire, where she dyed. Elizabeth lyes in the chappell of the French Hospitall at Madrid, where she dyed of a feavor at 10 days old. My next daughter of her name lyes buryed in the parish of Fotts Cray in Kent... my fourth daughter Mary lies in my father's vault in Hartford with my fourth son Henry. My eldest lyes buried in the parish church of St John's Colledge in Oxford, where he was born; my second Henry lyes in Begey Church in Hartfordshire, and my second Richard in the Esperance in Lisbone in Portugall $[\ldots] \cdot{ }^{33}$

This recapitulation of deaths through burial location identifies Fanshawe's own places of memory. Her wandering life has scattered the remains of her posterity across England, France and Portugal, tracing her journey as one of loss and death; and her careful recollection of the dispersed bodies of her children, with their repeated names (two Anns, three Elizabeths, two Henrys, three Richards), represents this recurrent scene of loss. ${ }^{34}$ The untold story of mortality has been transferred to the story of place: to

31 Fanshawe, Memoirs, 136.

32 Ibid., 139. Rose notes the 'complete identification with male superiority' implicit in this account, though Fanshawe's great sorrow at the loss of her daughter complicates this view (Rose, 'Gender, genre', 256).

33 Fanshawe, Memoirs, 106-107.

34 On magical beliefs about children's graves, see Jacqueline Simpson, 'The folklore of infant deaths. Burials, ghosts and changelings', in Gillian Avery and Kimberley Reynolds (eds.), Representations of childhood death (Basingstoke: Macmillan, 2000). 
name the location of the dead body is a way of containing and acknowledging death. But the dislocations of war have disrupted the connection between family and graveyard, and the work of retrieval struggles against the weight of death and displacement.

In contrast to Clifford and Fanshawe, both in different ways preoccupied with the deaths of children, Hutchinson's narrative gives only the scantiest details of her childbearing and its results. Few children are named, and even their number is uncertain. She mentions miscarried twins, the subsequent birth of twin boys, and the birth and early death of a third son, John - 'a very hopeful child, full of his father's vigour and spirit, but death soon nipped that blossom'. ${ }^{35}$ A daughter was born next, but 'was so weak a child that it lived not above four years'; a subsequent pregnancy is mentioned only because the birth brings to a head the parents' disquiet over infant baptism, and no name or sex is mentioned. ${ }^{36}$ Of the births, deaths, names and ages of her other (perhaps five or six) children there is no record. As Hutchinson decentres herself as a thirdperson narrator in her husband's war, the female world of childbearing seems equally decentred.

Despite her interest in ancestry, her concern is less with her children as bearers of lineage than of memory, perpetuating their father's virtues:

His memory will never perish while there are any good men surviving ... By the gracious precepts he left with his children to transfer to their posterity he will preach truth and holiness to succeeding generations. ${ }^{37}$

Her hopes rest in the future recognition of her husband's qualities. But his children are not sole possessors of his memory; the inheritance he leaves is intangible - moral integrity rather than name or property. (Literally, as it turned out; the family was left struggling and impoverished, and Lucy eventually sold the family estates to his half-brother.) Hutchinson's narrative reminds us that there is nothing essential in women's time; the repeated cycles of birth and death that in different ways govern Clifford's and Fanshawe's narratives are absent. Her account works in historical and in apocalyptic time: on the one hand the political and military events that constitute cause and effect; on the other the driving force of providence, God's will directing human events to their inevitable conclusion. Her act of recollection is melancholic because of two losses: her husband and

\footnotetext{
35 Hutchinson, Memoirs, 53.

36 Ibid., 91, 211.

37 Ibid., 337 .
} 
their shared politico-spiritual project. Her dead children cannot be integrated into this romance. But her sense of the historical sweep of the past perhaps allowed her to envisage a future renewal, even if not for herself, which was focused on a future broader than her own posterity.

\section{Memory, Family, History}

The time of family memory looks to both past and future: it holds the dead in the minds of the living, and transmits the responsibility for remembrance forward to children and grandchildren. Clifford's claim to her inheritance, Fanshawe and Hutchinson's grief for and justification of their lost husbands, are framed by historical narratives that support their arguments with reference to the past: the assertion of lineage, the bond of gentry to the land, God's plan for England. At the same time, the passing on of the story is continually vulnerable; the death of children, the failure of the political project, the unpredictable fragility of the future, all threaten to disrupt or destroy the wished-for continuity. These family histories are thus marked by repeated loss, as memory moves from living recollection to written record.

But memory is only part of their work, and these accounts also suggest that we need a more complex understanding of the relation between history and memory in order to grasp the ways in which seventeenthcentury women move between the two. Memory-keeping is an activity often associated with women, in ways which reinforce this divide. ${ }^{38}$ Women figure as custodians of the familial or cultural past, transmitters of traditions, guardians of the flame; nurturing and channelling activities, rather than investigative and analytic. ${ }^{39}$ But as family histories like these suggest, this view of memory-keeping is limited and limiting. Memory, as Raphael Samuel reminds us, is an active shaping force rather than a passive receptacle; and the memories recorded in these accounts are creatively and dynamically shaped, the outcome of research and interpretation, rather than simply transmitted. ${ }^{40}$ If these writings link past generations to the

38 On women's role in contemporary memory-keeping practices, see Anne Blue Wills, 'Mourning becomes hers. Women, tradition, and memory albums', Religion and American culture. A journal of interpretation 20:1 (2010) 93-121.

39 For a case study of the gendering of 'historical' and 'memorial' research in modern Iceland, see Susan Tucker and Svanhildur Bogadottir, 'Gender, memory, and history. In one culture and across others', Journal of archival organization 6 (2008) 288-310.

40 See Raphael Samuel, Theatres of memory, 2 vols, (London: Verso, 1993), vol. 1 Past and present in contemporary culture, $\mathrm{ix}-\mathrm{x}$. 
present, and to those who will come after, they do so through a process of selection and ordering which identifies the significant strands of lineage and history for each writer, and maps out the variable networks of past and future connections. Both public and private in their scope, both historical and memorial, they are reminders that such distinctions are shifting and contingent, and that our relation to the past is shaped both as history and as memory. 
Erika Kuijpers, Judith Pollmann, Johannes Müller, and Jasper van der Steen - 978-90-04-26125-9 Downloaded from Brill.com04/26/2023 11:57:20AM via free access 
CHAPTER SEVENTEEN

\title{
THE EXPERIENCE OF RUPTURE AND THE HISTORY OF MEMORY
}

\author{
Brecht Deseure and Judith Pollmann
}

In the last three decades, the idea of modernity has become tightly bound to the study of historical consciousness. Having abandoned the notion that there is only one path to modernity, more and more scholars have come to define modernity above all as a cultural habitus. Modernity is now less about doing objectively 'modern' things than about a form of selfawareness that makes people think of themselves or others as modern. In this definition, modernity implies above all an awareness of change and a sense of the past as non-repeatable, in short a 'modern' form of historical consciousness. ${ }^{1}$

Although scholars have differing views on the pace and nature of the emergence of this sense of a non-repeatable past, nearly all of them share the notion of a chronologically irreversible transformation, somewhere between 1500 and 1900, of pre-modern into modern ways of making sense of the past. Typically, binary concepts are used to describe this transformation: from traditional to modern, from cyclical to linear, from continuous to discontinuous. Modern ways of dealing with the past are thus assumed not to have complemented but to have replaced pre-modern ones. ${ }^{2}$

Both modernists and early modernists have long argued that the key catalyst for such a transformation of attitudes towards time and the past is the experience of rupture and crisis. ${ }^{3}$ Schematically put, the argument

${ }^{1}$ Marshall Berman, All that is solid melts into air. The experience of modernity (1st ed. 1982, London: Penguin, 1988); Stuart Hall, 'Introduction', in Stuart Hall and Bram Gieben (eds.), Formations of modernity (Cambridge: Polity Press, 1992), 1-16, esp. 15; Christopher Bayly, The birth of the modern world, 1780-1914 (Malden and Oxford: Blackwell, 2004), 9-10.

2 E.g. Matei Calinescu, Five faces of modernity. Modernism, avant-garde, decadence, kitsch, postmodernism (Durham: Duke Univ Press, 1987), 13-35; Aleida Assmann, Erinnerungsräume. Formen und Wandlungen des kulturellen Gedächtnisses (Munich: Beck, 2006), 50-55.

3 Expressed e.g. by Eric Hobsbawm, 'The sense of the past' in his On history (Weidefeld and Nicholson; London 1997), 10-24, there $12-15$. This essay was first published as 'The social function of the past. Some questions', Past \& Present 55 (1972). Among early modernists e.g. Peter Burke, The Renaissance sense of the past (London: Arnold, 1969), 
goes as follows: episodes of social, economic and political upheaval bring about a sense of temporal change and uproot traditional past relationships. These experiences of crisis and change create the perception of a gap between the past and the present, in which the present seems no longer to reproduce what had come before but instead brings novelty and difference. As a result, a new conception of time arises in which time comes to be conceived of not as a cyclical movement but as a process of linear development.

Many theorists of memory have pointed to the age of revolutions of the late eighteenth century as the period in which this transformation was most evident. ${ }^{4}$ In doing so, they roughly follow the line of reasoning laid out by Reinhardt Koselleck in his Vergangene Zukunft of $1964 .{ }^{5}$ But whereas Koselleck emphasised the role of intellectuals in the forging of these changes, many of his readers have tended to see the pace of change itself as the catalyst for changing perceptions of the past. In doing so they have highlighted the age of revolutions in the late eighteenth century as a period of change so breathtaking that it forever changed people's perceptions of the relationship between past, present and future. ${ }^{6}$ The events of the revolutionary and Napoleonic periods so fundamentally disrupted traditional society that they affected the way people related to their pasts. Writings of the period testify to a heightened awareness of change; a feeling of being cut off from one's past manifested itself, along with the feeling of acceleration of time. The past rapidly grew into the 'foreign country'

18-19, 149-150; Keith Thomas, The perception of the past in early modern England. The Creighton Trust Lecture 1983 (London: University of London, 1984); Daniel Woolf, The social circulation of the past. English historical culture, 1500-1730 (Oxford: Oxford University Press, 2003). Modernist approaches surveyed in Jeffrey K. Olick and Joyce Robbins, 'Social memory studies. From "collective memory" to the historical sociology of mnemonic practices', Annual review of sociology 24 (1998), 105-140, esp. 115-116.

4 E.g.: Jacques Le Goff, Histoire et mémoire (1st ed. 1977, Paris: Gallimard, 1988), 74-75, 155-160, 252-253; Berman, All that is solid, 17; Paul Connerton, How societies remember (Cambridge: Cambridge University Press, 1989), 6-7; Richard Terdiman, Present past. Modernity and the memory crisis (Ithaca and London: Cornell University Press, 1993), 3-32; John R. Gillis, 'Memory and identity. The history of a relationship', in John R. Gillis (ed.), Commemorations. The politcs of national identity (Princeton: Princeton University Press, 1994), 3-24, there 7; Anthony D. Smith, Nationalism (Cambridge: Polity Press, 2001), 49-53; Frank Ankersmit, Sublime historical experience (Stanford: Stanford University Press, 2005).

5 Reinhart Koselleck, Vergangene Zukunft. Zur Semantik geschichtlicher Zeiten (Frankfurt am Main: Suhrkamp Verlag, 1979). See also the introduction to this volume.

6 Berman, All that is solid, 17; Terdiman, Present past, 3-32. 
it constituted for the people of the nineteenth century. ${ }^{7}$ As Richard Terdiman puts it:

In Europe in the period of the 1789-1815 Revolution, and particularly in France, the uncertainty of relation with the past became especially intense. In this period people experienced the insecurity of their culture's involvement with its past, the perturbation of the link to their own inheritance, as what I want to term a 'memory crisis': a sense that their past had somehow evaded memory, that recollection had ceased to integrate with consciousness. ${ }^{8}$

Terdiman is only one of many who continue to argue for the long-term impact of this rupture. Philosopher Frank Ankersmit has similarly argued that the experience of the Age of Revolutions became a catalyst for the emergence of new conceptions of the past. ${ }^{9}$ In his Stranded in the Present. Modern Time and the Melancholy of History (2004), Peter Fritzsche has shown how both autobiographical and literary texts in the nineteenth century were pervaded by a sense of a rift and ever faster change, and argued that nostalgia was one of its main results. ${ }^{10}$ Arianne Baggerman, in a Dutch context, found little evidence for nostalgia but nevertheless a great sense of change and novelty pervading the diaries and life-writings from the first half of the nineteenth century. Like many others she credits this development to the fissures of the age of revolutions. And like others, she sees this sense of change expressed especially in comments on the impact of new technologies. ${ }^{11}$

Alluring and convenient as this scheme may be, this chapter will argue that it is not only untenable but also unhelpful. The scholarly evidence

7 Peter Fritzsche, 'Spectors of history. On nostalgia, exile and modernity', American Historical Review 105 (2001/5), 1587-1618.

8 Terdiman. Present past, 3-4.

9 Frank Ankersmit, Sublime historical experience (Stanford: Stanford University Press, 2005), 321-324.

10 Peter Fritzsche, Stranded in the present. Modern time and the melancholy of history (Cambridge Mass: Harvard University Press, 2004); Fritzsche has been strongly influenced by George Lukács' observations on the genesis of the historical novel: The historical novel (Boston: Beacon Press, 1963).

11 Arianne Baggerman, 'Lost time. Temporal discipline and historical awareness in nineteenth-century Dutch egodocuments', in Arianne Baggerman, Rudolf Dekker and Michael Mascuch (eds.), Controlling time and shaping the self. Developments in autobiographical writing since the sixteenth century (Leiden and Boston: Brill, 2011), 455-535; Arianne Baggerman, “"Zo een vrijheid begeer ik nimmer meer te beleven”. Het witwassen van het verleden in Nederlandse ego-documenten (1800-1850)', De negentiende eeuw. Documentatieblad werkgroep rge eeuw 33 (2009), 74-95. 
that has been presented to support the notion of a memory crisis around 1800 has rarely paused to consider pre-180o evidence in any detail. As we will demonstrate in this article, once we do so, we discover responses to rupture and novelty that complicate the notion of a linear development in the history of historical consciousness. When we explore early modern memory cultures in their own right, we can see that they cannot be reduced to the simple shorthand of 'historia magistra vitae'. More importantly, they make us aware that the after-effects of rupture are not always as long lasting as many scholars have led us to believe. Our starting point for this argument will be a text that suggests that even in the revolutionary era, some contemporaries thought that the pace of change which they were experiencing was not unique. Furthermore, by examining sixteenthcentury evidence we will show that many of those who experienced the Reformation and great civil wars of the period experienced a sense of rupture that was actually as profound as that of their successors around 1800 and with quite similar results; the same melancholic nostalgia, the same impulse to preserve the relics and remains, are in evidence. Yet we will also show that in the 16oos these feelings did not, apparently, lead to a lasting sense of change. Instead, within a generation or so people reshaped their image of the past in such a way that it could be reintegrated with their present selves.

But if early modern Europeans could accomplish such reintegration, should we assume that the same feat would have been impossible for people in the 1800 s? We think these findings invite us to rethink the relationship between rupture and the development of historical consciousness. We will argue that we need to abandon linear histories of memory in favour of a history that leaves more room for the coexistence, both before and after 1800, of different ways of negotiating the relationships between past and present.

\section{Novelties and Their Precedents}

From the 1780 s to 1817 Jan Baptist Van der Straelen, a citizen of Antwerp in the Southern Netherlands, kept a private chronicle. ${ }^{12}$ Private chronicles (better known to some as Gegenwartschronistik) are situated somewhere

12 Jan Baptist van der Straelen, De kronijk van Antwerpen, ed. Floris Prims, 8 vols. (Antwerp: Maatschappij 'Voor God en 't Volk', 1929-1936). 
between 'life-writing' or 'egodocuments' and historiography. ${ }^{13}$ Their authors recorded noteworthy events on a day-to-day basis, as in a diary, yet without including events from their personal lives. ${ }^{14}$ Their primary aim was to document and safeguard historical events for posterity. The genre was widely practiced throughout the early modern era. For our purposes, the use of these, often quite mundane, chronicles, has the advantage of reflecting actual people's experiences and memory practices and allowing us to compare these over a long timeframe.

Jan Baptist Van der Straelen was born in 1761 into a wealthy family of old-regime civil servants. ${ }^{15}$ Unlike his father and his brother he did not pursue a career in administration but became an antiquarian, devoting his life to art and the study of history. He became a specialist in the history and artistic heritage of his native city of Antwerp. The chronicle he kept between his early twenties and his late fifties is revealing about his political and ideological orientation, and shows us Van der Straelen as a profoundly conservative man, who was a firm supporter of the existing order. ${ }^{16}$ He was confident that the wellbeing of society depended on the

13 Marc Blanchard, 'Fin de Siècle Living. Writing the Daily at the end of the renaissance', in Philippe Desan (ed.), Humanism in crisis. The decline of the French Renaissance (Ann Arbor, MI: The University of Michigan Press, 1991) 223-257; Elisabeth Bourcier, Les journaux privés en Angleterre de 1600 à 1660 (Paris: Imprimerie Nationale, 1976); Rudolf Dekker (ed.), Egodocuments and history. Autobiographical writing in its social context since the Middle Ages (Hilversum: Verloren, 2002); Bettina von Krustenstjern, 'Buchhalter ihres Lebens. Über Selbstzeugnisse aus dem 17. Jahrhundert', in Klaus Arnold et al. (eds.), Das dargestellte Ich. Studien zu Selbstzeugnissen des späteren Mittelalters und der frühen Neuzeit (Bochum: Winkler, 1999) 139-146.

14 Ursula Ewald, Studien zur Entwicklung der britischen Gegenwartschronistik im 17. und 18. Jahrhundert (diss., Heidelberg: Grosch, 1964); Robert A. Fothergill, Private chronicles. A study of English diaries (London and New York: Oxford University Press, 1974); James Amelang, The flight of Icarus. Artisan autobiography in early modern Europe (Stanford: Stanford University Press 1998), 22-51; Georges Gusdorf: 'Conditions et limites de l'autobiographie', in Günter Reichenkron and Erich Haase (eds.), Formen des Selbstdarstellung. Analekten zu einer Geschichte der literarischen Selbstportraits. Festgabe für Fritz Neubert (Berlin: Duncker und Humblot, 1956); Philippe Lejeune and Catherine Bogaert, Un journal à soi. Histoire d'une pratique (Paris: Textuel, 2003); Urs M. Zahnd, 'Stadtchroniken und autobiographische Mitteilungen. Studien zur Selbstdarstellung spätmittelalterlicher Bürger', in Arnold et al. (eds.), Das dargestellte Ich, 29-51. Jonathan Barry, 'Provincial town culture, 1640-1780. Urbane or civic? In Joan H. Pittock and Andrew Wear, Interpretation and cultural history (London; Macmillan, 1991), 198-234; Jeroen Blaak, Literacy in everyday life. Reading and writing in early modern Dutch diaries (Leiden: Brill, 2009), 189-264.

15 Johannes G. Frederiks and Frans J. van den Branden, 'Straelen (Jan Baptist van der)', in Idem, Biographisch woordenboek der Noord- en Zuidnederlandsche letterkunde (Amsterdam: Veen, 1888) 764; Floris Prims, 'Inleiding', in Van der Straelen, De kronijk, ed. Floris Prims, vol. 1, 7-14.

16 Brecht Deseure, 'Den ouden luijster is verdwenen. Geschiedenis, herinnering en verlies bij Jan Baptist Van der Straelen (1792-1817)', Belgisch Tijdschrift voor Nieuwste Geschiedenis $10(2010 / 4) 517-555$. 
conservation and maintenance of that order, which, throughout its long history, had become perfectly adapted to the people's needs and interests. The task of the present generations consisted in safeguarding the legacy of their ancestors and passing it on untarnished to their own offspring.

Underlying this conservatism was a quite distinctive relationship to the past, both before and after the Revolution. As any reader of Terdiman or Fritschze would expect, before the Revolution, Van der Straelen experienced the relationship between the present and the past as one of continuity. In his view, the present should reproduce the past by conforming to the models provided by history. Three elements in particular ensured this continuity: the old privileges and constitutions, the Catholic religion and the material remains of the past. They forged a bond, as it were, between the present people and their earliest history. The first element, the privileges and constitutions, formed the formal basis of old-regime society. They functioned according to the omnipresent logic of historical precedent, in which history was considered the ultimate source of legitimisation. The older the title, the better. 'Our old laws, privileges and customs', as Van der Straelen dubbed them, ensured the preservation of institutions and corporations, many of which had been functioning since the Middle Ages. No changes were to be introduced, lest the bond with the past be broken. Tellingly, Van der Straelen put great store in recording events that recurred on a yearly basis, such as processions, feast days or the renewal of public offices. Often he would mention the year in which the particular tradition was instated and emphasise that its observance had never been omitted since.

The second pillar of his bond with the past was the Catholic religion. This too was an ancestral heirloom which generation upon generation had passed on to its successors. Van der Straelen described: That old Roman Catholic faith, brought to our lands by the apostles and in which the inhabitants have been carefully brought up by their parents'. ${ }^{17}$ Like a string of beads it ran through the centuries and connected the present time to the earliest days of Christianity.

The final pillar consisted of the material remains of the past. As an antiquarian and a historian, Van der Straelen was an expert on the history of his city, the remains of which surrounded him on all sides. He read the townscape like a history book. Every façade, every church, every tomb and every coat of arms incarnated an element from that history. He did

17 Van der Straelen, De Kronijk, ed. Floris Prims, vol. 4, 238. 
not consider these elements the remnants of a dead past. On the contrary: they embodied it, safeguarded its memory and legitimised the existing order. As a consequence he greatly disapproved of any changes or acts of modernisation that threatened the material remains of the past because they endangered the link between the past and the present.

But of course, changes did come. Not surprisingly, Van der Straelen firmly condemned the revolution that took place in France. Not only did it topple the old regime of which he so thoroughly approved, but its antihistorical inspiration also jeopardised the legacy of the past. Great was his anxiety when the revolution suddenly came very close. In 1791 France went to war with Austria. As a result of the conflict the Southern Netherlands (part of the Austrian Habsburg possessions) were invaded and temporarily occupied by French troops. From 1794 on, the occupation became permanent. The Southern Netherlands were formally annexed to France and would remain so for the next twenty years. During these years the region was revolutionised from above. The old regime was abolished, and the existing structures of society were progressively dismantled.

Unsurprisingly for someone of his persuasion, and again in line with what Terdiman and Fritzsche have taught us, Van der Straelen experienced these developments as a disaster. His worst fears came true when the new French government abolished the old privileges and institutions, outlawed Roman Catholicism and started to systematically erase the material remains of the old regime. The pillars of Van der Straelen's sense of continuity with the past collapsed one by one. His desperate comments in the chronicle bespeak his fear of a complete break between the past and the present. Every time an institution or tradition was abolished, he bitterly looked back on its long history and lamented its demise. When the annexation by France was officially announced, he wrote: 'All good citizens were full of sadness because of these changes, and rightfully feared the complete downfall of the old constitution. Yes, one was greatly apprehensive of the introduction of all the French novelties'. ${ }^{18}$ The revolutionary measures indeed threatened to cut off every connection with the past. When the monasteries were dissolved and the parish churches began to be closed down, Van der Straelen wrote: 'And thus our religion and the public practice of that ancient Roman Catholic faith, preached in our lands from the time of the apostles on, ceases and is forbidden by its enemies.' 19

18 Ibid., vol. 5, 100.

19 Ibid., vol. 6, 118. 
Particularly unbearable for Van der Straelen was the attack on the material remains of the past. He experienced their disappearance as a double disaster, as his comments in the chronicle show. Not only did it threaten historical continuity, it also endangered the memory of the past itself. As the material supports of memory disappeared, whole chunks of history risked falling into oblivion. As historical landmarks were torn down, commemorative inscriptions were wiped out and noteworthy tombstones were smashed, the whole fabric of remembrance unraveled. Van der Straelen reacted by frantically recording every ancient object, text or building that had disappeared. In order to perpetuate the memory of the past, he made his chronicle the repository of all things lost. When the public display of religious symbols was banned, Van der Straelen scrupulously recorded every crucifix and saint's figure that was taken from view. Some of his friends went further and tried to salvage the confiscated objects themselves by illegally removing them. The chronicle contains many adventurous anecdotes of such attempts, including the clandestine opening of the mausoleum of the fifteenth-century countess Isabella of Bourbon so as to keep her earthly remains from falling into the irreverent hands of the revolutionaries.

All in all Van der Straelen's reaction to the revolutionary upheavals was very similar to those described by Fritzsche and others. The invasion of novelties he and his contemporaries faced, affected their perception of the relationship between the past and the present. Whereas these had formerly been connected by historical continuity, they now seemed to rapidly drift apart. Like many others Van der Straelen pointed out a change of times, a reversal in the temporal process. He typically experienced a sense of loss when confronted with the fundamental transformation of the world he had known. Again like many others, he stressed the newness of the revolutionary events, calling them 'unheard-of novelties'. He most powerfully expressed this feeling of novelty when commenting on the public auctioning of the furnishings of the Antwerp city hall, which included many objects of great historical and artistic value: 'Has anyone ever read about examples such as the ones perpetrated here today? Can similar things actually be found in the old chronicles?'. ${ }^{20}$

It is here that something surprising happens. Because Van der Straelen's answer to his own rhetorical questions was actually a resounding yes. Although Van der Straelen did cry out against the unheard-of character

20 Ibid., vol. 7, 95. 
of some revolutionary measures, most of them did not really strike him as unprecedented. To be sure, he called them 'new', meaning that they deviated from common practice. But they were not without historical parallels. Many of them echoed the calamities of the sixteenth century, when Antwerp had been a bulwark of the Protestant Reformation and civil war had raged in the Netherlands. When the Catholic clergy was being prosecuted by the new French government, Van der Straelen wrote: 'it seems as if the disasters and the unhappy times of the sixteenth century are coming here again'. ${ }^{21}$ When the public display of religious images was banned, he called it 'a second iconoclasm of 1566 ' ${ }^{22}$ Sometimes the parallels got very literal, as when the very same wonderworking statues or precious religious objects that had survived the Dutch Revolt had to be hidden away again, just as they had been in the sixteenth century. It was not only in religious matters that he found parallels with 'those sad and unhappy times', as he called them. All kinds of events turned out to be repetitions of sixteenth-century occurrences, despite their apparent novelty.

This finding has two important implications for our understanding of early modern memory. Firstly, Van der Straelen already had a well-developed sense of historical discontinuity before he personally experienced feelings of temporal change. Although he was a militant defender of the old regime and felt directly connected to a distant past, he was very well aware that time did not always move within the same cycle. He knew dramatic changes in the course of time had occurred before and could occur again. Secondly, he did not experience the crisis of his own time as something completely new and unprecedented. Actually, he could easily think of historical parallels. He did consider the changes produced by French occupation a rare disaster of extreme dimensions, but he did not consider them a unique event.

This picture is markedly at odds with Terdiman's and Fritzsche's account of the experience of time in Europe around 1800. If they are to be believed, contemporaries of the French Revolution had no choice but to feel suddenly and dramatically cut off from their own pasts. The example of Van der Straelen suggests that this is only partly true. By focusing exclusively on the experience of novelty, defenders of the modernity thesis seem to have lost sight of the persistence of other forms of making sense of change, including comparison with events from the past.

21 Ibid., vol. 4, 239.

22 Ibid., vol. 6, 87 . 
What should we deduce from this evidence? First, it is possible that the sense of total rupture between past and present which scholars have claimed accompanied modernity actually has to be sought later in the nineteenth or even in the twentieth century. There are certainly scholars who have suggested that it was events other than the French Revolution that caused the fissure between past and present. $^{23}$

\section{Pre-Modern Memory Crises}

Yet there is another possibility, too. Perhaps we need to rethink the relationship between experiences of rupture and historical consciousness. So far, scholars have assumed that the changes in notions about the past that are brought about by the experiences of rupture are irreversible. But is there really no alternative? To what extent can we assume that the loss experienced by a generation leads to irreversible changes in the historical consciousness of subsequent generations?

Pre-modern examples suggest that the long-term impact of experiences of rupture can be quite different. Crises of memory of the kind that Van der Straelen and his contemporaries experienced around 1800 were not new. The reactions of sixteenth-century chroniclers to the calamities of their time had been surprisingly akin to Van der Straelen's. As we will see, they too had feared the complete downfall of the old order. They too found themselves surrounded by novelties that seemed to threaten historical continuity. They too had felt cut off from the past as the present seemed to drift ever further away. Judging by this early modern evidence, however, it is our impression that the effects of dislocation can wear off quite soon, sometimes even within the people who experienced the loss.

In a path-breaking lecture of 1985 entitled the The Perception of the Past in Early Modern England, Keith Thomas described a much earlier transfor-

23 See for a useful overview of these timeframes Olick and Robbins, 'Social memory studies', and Jeffrey K. Olick, The politics of regret. On collective memory and historical responsibility (New York: Taylor \& Francis, 2007), 175-192; Pierre Nora et al., Les lieux de mémoire, Bibliothèque illustrée des histoires (Paris: Gallimard, 1984-1992). On the chronological indistinctiveness of the terms modern and pre-modern see Penelope Corfield, Time and the shape of history (New Haven: Yale University Press, 2007). 
mation in historical consciousness, in terms that are the spitting image of those used by Terdiman and Fritzsche:

The dramatic rupture with the medieval past occasioned by the Reformation created a sense of separateness and of an unbridgeable divide. This made it possible to perceive the recent past, not just as a collection of founding myths and precedents but as the embodiment of an alternative way of life and set of values. ${ }^{24}$

Using a range of sixteenth- and seventeenth-century sources Thomas pointed to a widespread nostalgia for the pre-Reformation past, when England had been 'merry', life had been simpler, and charity and hospitality abounded. Many lamented the lost abbeys and other sacred spaces of the Catholic world, and antiquarians set out to document their existence before the last traces had vanished. Margaret Aston had already shown that in England, this sense of loss resulted in a rush to salvage what remained. ${ }^{25}$ And since Thomas' lecture, the work of other scholars has presented much more evidence for this sense of dislocation. ${ }^{26}$ English Catholics, especially, experienced the break with the religious past in a very emotional manner:

The tyme hath been wee had one faith

And strode aright one ancient path

The thym is now that each man may

See new religions coynd each day

The tyme hath been the prelate's dore

Was seldome shotte against the pore

The tyme is now, so wives goe fine

They take not thought the kyne. ${ }^{27}$

This sentiment was not confined just to England. The changes brought about by the Reformations of the sixteenth century were momentous indeed, not only because they were accompanied by political shifts and religious wars, or because they divided families, but also because they called into question fundamental relationships between the living and

24 Thomas, The perception of the past, 9 .

25 Margaret Aston, 'English ruins and English history. The dissolution and the sense of the past', Journal of the Warburg and Courtauld Institutes 36 (1973), 231-255.

26 Adam Fox, 'Remembering the past in early modern England. Oral and written tradition', Transactions of the Royal Historical Society, 6th series, 9 (1999), 233-256; Alison Shell, Oral culture and Catholicism in early modern England (Cambridge: Cambridge University Press, 2007); Alexandra Walsham, The Reformation of the landscape. Religion, identity, and memory in early modern Britain and Ireland (Oxford: Oxford University Press, 2011).

27 Woolf, The social circulation, 340. 
the dead, the sacred and the profane, the material and the spiritual. It is no wonder that a sense of sudden change and of dramatic loss proved important incentives for many in sixteenth-century Europe to document their experiences. 'Nothing in the world remains certain. Nature does not persist in its own laws, and all laws lie in confusion', wrote Arnold Buchelius, a young man who had been born on the eve of the Dutch Revolt that within in a few decades would tear his world apart. Like Van der Straelen, he kept a chronicle of the events of his time, which ran from the years just before his birth in 1565 to the late 1590 , and he again recorded his everyday experiences in the 1620 s and ' 30 . As a consequence of the Revolt and the ensuing Reformation, he documented a strong sense of rupture and loss:

I suppose nothing at all has been done outside the usual and just order, when the ancient laws have been powerless [...] in the town of Utrecht, so that, with the council brought down, cobblers may rule [...]. While the common people live according to their own wishes [...] the feeble decrees of the inert council are changed with every hour. Hence right and wrong are put to similar uses and the widest door is open to every possible crime.

Like Van der Straelen, Buchelius had a large stake in the existence of the old order; as the illegitimate son of an Utrecht canon, he saw the Revolt destroy both the church in which his father had made his career and his own prospects for a career in the city's elite. He reported that: 'today, one may safely defame another man's reputation, thefts, too, go unpunished, deceit and perjury are profitable'. The social order had been turned upside down. ${ }^{28}$ Not only socially, but also in religion, everything had changed:

Our ancestors had one way to [the] true goal, those who live now have another. Now the altars of the saints have been overturned, the images and ornaments variously destroyed, many monasteries and churches lie torn down to their foundations. This is the eagerness of mortals for novelty [...].

The loss of the past moved him to start documenting the material remains which were under threat; he copied epitaphs, drew stained-glass windows, and described buildings, because:

[Protestants] neglect the monuments of the ancients and do not attend to the memorial masses of our ancestors, saying that their names have already

28 Judith Pollmann, Religious choice in the Dutch Republic. The reformation of Arnoldus Buchelius, 1565-1641 (Manchester: Manchester University Press, 1999), 52. 
been written in heaven, so that some of them seem more barbaric than the Goths themselves. ${ }^{29}$

He spent the rest of his life as an antiquarian scholar, documenting the past, and also clearly aware of the enormity of this task. People thought he had nothing to do, he wrote in 1632:

But they not know what it is like to deal with books, and to digest the acts of so many thousands of years or to let one's mind run over so many changes, mutations, conditions, great events of peoples, kingdoms and provinces. There is no greater immensity than this. ${ }^{30}$

Just as for so many who experienced the age of revolutions, the experience of rupture had thus resulted not only in a sense of loss but also in an acute awareness of the risks of oblivion and an agenda for action to counteract these threats. Buchelius became a historian with a keen sense for the 'mutations' in history.

Yet if Buchelius' experiences seem to confirm that experiences of rupture can make people painfully aware of the differences between past and present and lead to a nostalgic interest in the world of the past, his example also shows that the impact of rupture is not necessarily of lasting significance for the way in which people experience the past. Because Buchelius' nostalgia about the Catholic past did not last; he soon began to appropriate the notion that the changes which his society had witnessed had in fact been for the good. He became a Protestant, first reluctantly so, but later a real hardliner. At some point in his life he literally crossed out the angry poems about the Revolt that he had written as a youngster. Buchelius always remained a deeply conservative man, yet his notion of what was to be conserved underwent a transformation; in the 1580 s, he had bemourned the Reformation but in the 1620 s he was idealizing the early phases of Revolt and Reformation. 'Oh poor Republic', he exclaimed about the new state whose founding he had once deplored, 'that once flourished but now lies trampled under the feet of the same men who disregard the benefits they have reaped, and with shameless prevarication try their hardest to suppress the hereditary liberty.' ${ }^{31}$

His nostalgia thus remained, but it associated itself with another picture of the past, which enabled him to reconcile it with his identity in the present. If this sort of transformation can happen within a generation, it is

\footnotetext{
29 Ibid., 86.

30 Ibid., 191.

31 Ibid., 151-152, 162.
} 
no wonder that the children and grandchildren born to those traumatised by dislocation end up integrating many of 'new' developments into their picture of the 'old' order. Thus, it took Calvinists in England and the Dutch Republic only a generation to start defending what they now considered to be their 'old' religion against the challenges of 'novelties' imposed by the Arminian party. ${ }^{32}$ After the disruptions of war, people nevertheless found ways to re-imagine their histories as a continuum. ${ }^{33}$ The past itself is not ignored, but it is re-imagined to suit our present needs.

\section{Conclusion}

Feelings of temporal change and discontinuity can hardly be called distinctively modern, and they were part and parcel of early modern experiences of time. In their search for the progressive modernisation of Western historical consciousness, scholars have tended to over-emphasise the uniqueness of the memory crisis of around 1800. As it acquired the status of a watershed between pre-modern and modern ways of making sense of the past, it came to be considered as a completely new event. This mechanism has obscured the many parallels between this crisis and its early modern predecessors. In fact, the French Revolution caused what was only one in a series of memory crises. Acknowledging this, of course, has consequences for our assumptions about the relationship between rupture, modernity and a sense of the past. Because if earlier memory crises had not led to the birth of 'modernity', we can no longer assume that it was such a crisis of memory that, in and by itself, can be credited with the emergence of a modern worldview around $1800 .^{34}$

What are the alternatives? Some scholars have tried to trace the advent of modern historical consciousness to earlier moments of crisis. In the last decades early modernists have been keen to stress the early modern origins of several of the traditional accessories of modernity. This has led to more refined chronologies that credit the Reformation, the sacco di Roma, Puritanism or the English Civil Wars with bringing about a modern aware-

32 Charles H. Parker, 'To the attentive, nonpartisan reader. The appeal to history and national identity in the religious disputes of the seventeenth-century Netherlands', The sixteenth century journal 28 (1997), 57-78.

33 For another example see e.g. Karel Degryse, Pieter Seghers. Een koopmansleven in troebele tijden (Antwerpen and Baarn: Hadewijch, 1990).

34 E.g. Berman, All that is solid, 17; Terdiman, Present past, 3-5. 
ness of change. ${ }^{35}$ Yet how helpful is it to keep looking for a 'modern turn' in the history of historical consciousness? The incompatibility of these alternative chronologies, for one thing, suggests it is not. The linear thinking underlying these quests for origin favours schemes of development in which new ways of making sense of the past replace older ones. In reality, however, several of these attitudes can coexist at the same time or dis- and reappear. As the example of Buchelius shows, it is possible for one and the same person to bemourn the past one moment and embrace change the next.

The existence of a crisis of memory around 1800 as well as its early modern and possibly even medieval predecessors cannot be denied. People's relationships with the past were indeed deeply shaken. Very real feelings of a break between the past and the present were shared by many. There can also be no doubt that experiences of change have influenced the way in which people experience the relationship between past and present. Yet these experiences of transformative change were neither unique, nor need we assume that they necessarily had a lasting impact on people's perceptions of the world. Rather, our examples suggest that there are other ways of accommodating change. We do not want to claim that the responses of Van der Straelen or Buchelius are typical, or the only possible, reactions to rupture. Van der Straelen tried to frame and interpret his experiences by placing them in a historical perspective, as have many others since his time. As Eric Hobsbawm pointed out in 1972, one of the interesting and quite unexpected characteristics of modernity is the ongoing interest in the past. ${ }^{36}$ Buchelius' example suggests a second response, which is to accommodate and integrate the new by reimagining the past and remaking it into a shape that accords with the needs of the present. Together, these cases suggest we need to think less in terms of linear and irreversible changes when considering the history of memory and instead be aware that different ways of negotiating the past, or modes of thinking about it, can coexist, not just in societies but indeed in individuals.

35 John G.A. Pocock, 'The origins of the study of the past. A comparative approach', Comparative Studies in Society and History 4 (1961-1962), 209-246; Jo Tollebeek, 'De conjunctuur van het historisch besef', in B. Raymaekers and D. Van Riel (eds.), De horizonten van weten en kunnen (Leuven: Universitaire Pers Leuven, 2002), 167-193; Woolfe, The social circulation.

36 Hobsbawm, 'The social function of the past. Some questions'. 
Erika Kuijpers, Judith Pollmann, Johannes Müller, and Jasper van der Steen - 978-90-04-26125-9 Downloaded from Brill.com04/26/2023 11:57:20AM via free access 


\section{INDEX}

Abaúj, 99

abbeys, 158, 197-98, 273, 325

Abraham, 283, 291

Accession Day, 7, 286

Adolf, Gustav, 273

Aeneas, 291

Alba, Fernando Álvarez de Toledo, duke of, 47, 57-6o, 187, 283, 292

album amicorum, 291

Alkmaar, 144, 188, 191

altars, 6, 261, 326

Amboise

Conspiracy of, 113

Edict of, 116

Americans, native, 13, 212

Americas, 12-13, 78, 212

Amsterdam, 6, 140, 193-194, 292-293

Anabaptists, 6

anachronism, 4, 21-22

ancestors, 6, 20, 30, 32, 35-38, 41-42, 158 , 170, 191-192, 198-199, 285, 289-294, 305, $308,310,320,326$

Anchin, Abbey of, 197-198

Anderson, Benedict, 1-2, 224

anecdotes, 184, 258, 299, 306, 307, 322

Angel, Philips, 236

Ankersmit, Frank, 317

Anne, Queen of Great Britain, 63, 69-72, 74-75

Anne of Cleves, 176

antiquarianism, 7, 16, 161, 183, 190, 199, 298, $319-320,325,327$

Antwerp, 51, 116, 141, 187, 189, 288-293, 318-319, 322-323

apocalypse, 311

Apology, see William I, prince of Orange

apostles, 170, 320-321

Appadurai, Arjun, 27-28, 34, 43

Arbaleste de la Borde, Charlotte, 18, 260-261, 263

Archer, Ian, 173

Armenians, 7-8, 27-43

Arminianism, 45-61, 328

Arminius, Jacobus, 45-46, 51

artefacts, 10-11, 22, 115, 118, 131, 136, 139, $141,147,165,167,171-174,177,180-181$, 203-206, 211, 216-218, 221, 224, 235, 244,
248, 250, 256, 262, 265, 266, 322, 323 see also paintings

cabinets, 14, 224, 233-235, 239, 241, 249

delftware, 231, 235, 239

inscriptions, 11, 123-124, 171-173, 178, 180, 322

medals, $6,11,65,133,134,136,139$, 143-145

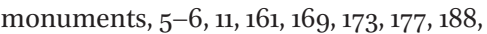
200, 305, 326

silverware, 134-136, 139-140, 147, 169-172, 180, 183-184, 231

stained glass, 11, 169, 170, 179, 326

statues, $176,218,257,323$

Asia, 14, 162, 223-250 see also China

Assendelft, 194

Assmann, Aleida, 1, 186, 206, 209

Assmann, Jan, 1, 186

Aston, Margaret, 325

Atterbury, Francis, 69-70, 72-73

Aubigné, Agrippa d', 113, 124

Augsburg, 8, 77-91

Peace of, 91

Austria, 215-216, $3^{21}$

autobiography, 16-19, 95, 100, 197-199, 215, 258-259, 270-271, 273, 275-276, 279-28o, $291,317,319$

Auxerre, 123

Avallon, 123

Avignon, 115-116

Babylonian Captivity, 291

Bacher, Andreas de, 288

Bács, 99

Bakócz, Tamás, cardinal, 100

Baldaeus, Philip, 235-236

Bamberg, 269

Bartlett, Richard, 157, 161

Batavians, 293

Batory, Stefan, king of Poland, 30, 32

Beggars, 187, 237

songs, 132

Békés, 99, 104

Bellers, Fulk, 283

Benedictus of Nagyhatvan, 98

Benjamin, Walter, 2, 324

Beuf, Jean le, 123 
Bible, $11-12,53,78,85,87,88,114,155,178$, $189,283,291$

Chronicles, 85

Exodus, 85

Samuel, 87

Bihar, 99-100, 104

biography, 102, 204, 219, 284, 291

Black Legend, 13, 189, 211-213

Blackall, Offspring, 69, 72-73

blood, 49, 237, 259, 276, 278, 301, 304

Blount, Charles, see Mountjoy, baron

Bodrog, 99, 104

bodies, 14, 18, 22, 52, 101, 108, 167, 171, 176, 177, 194, 229, 241, 243, 258, 259, 261, 270, 273, 276, 277, 284, 310, 311

Bohemia, 231, 283

Bol, Ferdinand, 291

Bor, Pieter, 57

Bossuet, Jacques-Bénigne, 121

Bourgeois, Louise, 264-265

Boyle, James, 161

Boyle, Roger, 155

Brabant, 129-131, 141, 183, 187

Breda, 10-11, 129-136, 139-147

Britons, 308

Bruges, 187,190

Brussels, 58, 288

Buchelius, Arnold, 326-327, 329

buildings, as sites of memory, $173^{-174}$, $180-181,326$

Bunyan, John, 12

Burke, Peter, 154

Burmania, Poppo of, 141

Burnet, Gilbert, 64, 66

Butler, James, see Ormonde, duke of

Bynum, Carolyn Walker, 218

Caffa, Pontic Island of, 41

calendar, 7, 8, 77-91, 119, 124-125, 168, 170, 305

Calvin, John, 54

Calvinism (see also Huguenots), 12, 45-61, 187, 189, 195-199, 236, 255-264, 279, $283^{-287}, 328$

Cambrai, 136

Cambry, Pierre de, 198-199

canon, historical, 8, 41, 45-46, 58, 60-61, 70,

$74,75,130,186-187,189-190,286$

Capet, house of, 293

capitalism, 1, 3

cardinals, $36,93,97,99,124$

Carleton, Sir Dudley, 49-52

cartography, 132, 143, 156-161, 224

Casas, Bartolomé de las, 212
Casimir III, king of Poland, 29, 37

Catholicism, 7-8, 36, 39, 50, 52, 65, 71, 118, 122-123, 161, 163, 189-190, 196, 198-199, $218,236,290,320-321,325$

Catholic League, 10, 111, 112, 120, 122-125

Caumont, Jacques Nompar de, 259

ceremonies, $117-118,165,188$

Cevennes, 12

Charles II, king of England, 150, 158, 301

Charles IX, king of France, 121

Chartres, 117

charters, 7, 27-43, 180

Chichester, Arthur, 155

childbirth, 256, 273, 290, 301, 307-311

childhood, 29, 31, 271-272

China, 223-250

Christian II, elector of Saxony, 177

chronicles, 6, 16-18, 20, 21, 35, 98, 105, 108, $115,116,151,183,190,196,256,257,263$, 269, 270, 280, 283, 285, 293, 294, 309, 318, $319,321,322,324,326$

Churchill, Winston, 9

Cicero, Marcus Tillius, 162

city hall, 117,322

civic militia, 187-188, 191

civil war, 9, 45, 112-121, 187, 318, 323

in France, see France, Wars of Religion

in the Netherlands, see Dutch Revolt

in England see England

Spanish, 213

Clarke, Samuel, 283

Clemens, Canimich, 93-94, 97

clergy, $16,40,47,54,56,58,67,68,70,85,86$, 93-95, 97-99, 100, 102, 115, 118, 124, 151, 16o, $161,168,170,188,190,209,237,27,323,279$

Clermont, Archange de, 118

Clifford, Anne, 300, 302-305, 308-309, $311-312$

Clifford, George, see Cumberland, 3rd earl of coat of arms, 36, 292, 320

Coburg, 219

Cohen, Robin, 209

Colchester, 283

Commonwealth, Polish-Lithuanian, 41

compassion, 105, 276

Confession, Belgic, 53

conquest, 28, 31, 33, 42, 132, 151, 155, 161

conservatism, 319, 327

constitution, 52, 65, 72, 78, 84-90, 320, 321

continuity, 7, 16, 27, 35, 162, 167, 190, 203,

$301-305,308,309,312,320-324$

convents, 19, 257, 261, 262, 269

conversion, 20, 22, 111, 123, 215

Coote, Charles, 155 
Corpus Christi, feast of, 171

Cortes, Adriano de las, 245, 248, 250

Couchey, 263

Council of Troubles, 58-6o

Counter-Reformation, 190, 199

Counter-Remonstrants, 46-61, 291

Cousin, Jean, 196-197, 199

craft guilds see guilds

Creet, Julia, 207

Crespin, Jean, 113

Cromwell, Oliver, 10-11, 149-164

crucifixes, 257, 322

crusades, 13, 93, 97-101, 219

Csanád, 99

Császár, Peter, 108

Cumberland, George Clifford, 3 rd earl of 303

customs, 6, 8, 162, 181, 257, 320

Czarny, Leszko, 35-36

Dam, Leendert Ariensz. van, 192

Daniel of Galicia, king of Ruthenia, 43-52, 55

Danish-Halle Mission, 210

Dapper, Olfert, 225-226, 235, 243-244

Dathenus, Peter, 55

David, king, 87

Davies, John, 156-157

Davila, Enrico, 120

Declaration of Reasons, 64-67

Declaration of Rights, 66-67

Defoe, Daniel, $71-72$

delftware, see artefacts

Den Bosch, 143-144, 188

Den Briel, 191

desecration, see sacrilege

despair, see emotions

Deventer, 132

devotion, 18, 105, 118, 165, 174-176, 190, 193, $196,197,216-218,258,283,284,300,303$

diaries, 16, 41, 210, 270, 273, 279, 302-209, 317,319

diaspora, 13, 38, 209-211, 217, 283-288, 294-295

Dijon, 123, 264

discontinuity, 162, 323, 328

distress, see emotions

divine intervention, see providence

Dmitry (aka Lubart), prince, 39-42

Dordrecht, $5^{8}$

Dorset, Richard Sackville, 3rd earl of, 304

Douai, 187, 195, 197

Dózsa, Georgius, 93, 99, 101, 104-109

drama, 24-25, 128, 130, 135-136, 138-139, 145, 170,180
Drew, Richard, 12

Drogheda, 149-150, 155, 157, 163

Dublin, 153, 159

Duin, Arnoldus van, 191, 199

Dundrum, 159

Dupleix, Scipion, 121

Duplessis-Mornay, Philippe, 260

Dutch Republic, 8, 11, 45, 46, 58, 129-132, 140, 143, 146, 147, 187, 190, 288, 290, 293, 294, 328

Dutch Revolt, 8, 11, 129-147, 183-202, 212, $288-292,323,326$

Duym, Jacob, 135, 140

education, 38, 209, 298

Egmont, Lamoraal, count of, 58

Egmont, Louis Philip, count of, 198

Egypt, 12, 189

elderly, 15, 49, 108, 264

elites, 4, 9, 16, 42, 77-78, 81, 98, 108, 117, 124, $131,135,147,150,170,180,187,191,229,245$, 258-259, 288, 291-294, 301, 326

Elizabeth I, queen of England, 283, 286, 294

Emden, 53-54 synod of, 53

emotions, 14-19, 153, 197, 208, 215, 253-267, 269-282, 295, 308-310, 318

despair, 18, 261 distress, $7-18,162 \mathrm{~m}, 25^{1-267}, 271,280$ fear, 17-18, 20-21, 93, 97, 108, 197, 257-258, 261, 266, 269-282, 321, 324

endogamy, 288, 295

England, 4, 7-8, 16, 63, 65, 68-71, 75, 118, 150, 152, 160, 164, 174, 211-213, 215-216, 283-284, 291, 293-294, 297, 308, 310, 312, $324-325,328$

civil wars, 70, 74, 152, 302-303, 307, 328

commonwealth, 156, 306-307

Glorious Revolution, 8, 63-75

restoration, $150,158,306,307$

Enlightenment, 14, 162, 270, 279

epitaphs, 169,326

Erll, Astrid, 12

Escalade, commemoration of, 117-118

eschatology, 2-4, 85

Esposito, Elena, $2-3$

Essex,

Robert Devereux, 2nd earl of, 155

Walter Devereux, 1st earl of, 155

Esterházy, Nicolaus, palatine of Hungary 105,108

executions, 58, 94, 97, 98, 101, 105-109, 151, 160,274

Exeter, 64 
exiles, 20, 58, 78, 84, 87, 112, 189, 209, $283-295,306$

eyewitnesses, 14, 16, 151, 184-185, 236, 248-249, 256-259, 262, 266, 269, 275

Eynde, Jacob van den, 60

family, 6, 11, 15-16, 18, 20, 22, 123, 143, 171-173, 185, 191-193, 198, 209, 213, 215, 217, 219, 259, 262-266, 283-296, 297-313

family histories, $6,11,15^{-16}, 20,22,123$, 191-192, 198, 209, 215, 264, 283-295, 297-313

famine, 144, 149, 262-263

Fanshawe, Anne, 300-303, 305-307, 309-312

Farnese, Alexander, duke of Parma, 129, 189,290

Fear, see emotions

Fenicio, Jacopo, 236

Feodor/Theodore, prince, 39-42

Ferdinand II, holy roman emperor, 177

Ferry, Paul, 119

Flanders, 284

Fleming, Robert, 71

flight, see exile

folkloric, 11, 149-163

forgetting, see oblivion

France, 10, 48, 68, 284, 290, 293, 310, 317, 321 Revolution, 315-329

Wars of Religion, 9, 111-125, 251-267

Frederick Henry, prince of Orange, 140, 143-144, 147, 183

Fredrick the Wise, 219

freedom, 14, 39-40, 57, 60, 187, 189, 193, 199, 217,327

Fritzsche, Peter, 317, 320-323, 325

future, 4, 63, 102, 104, 135, 143, 200, 215, 257, 264, 271, 281, 289-90, 299-313, 316

Galway, 159

gender, 255, 266, 297-313

genealogy, 6, 16, 140, 179, 285, 290, 291, 299-306

generations, 11, 38, 42, 111-112, 118, 121, 123, 157, 181, 185-186, 190, 199, 203, 206, 211, 213-217, 220-221, 284, 289, 294, 297-313, $318,320,324,327-328$

war, 186, 199

Geneva, 116, 118, 195

genre, 17-18, 98, 118, 152, 185, 224, 229, 236, 248-249, 251, 254-255, 265-266, 297-302, 319

gentry, $297-313$ geography, 14, 156, 208, 223-250

George I, king of Great Britain, 74

Ghent, 16, 55, 187, 190, 288

Gillis, John, 4

Gladstone, William Ewart, 9

Gleixner, Ulrike, 215

Glorious Revolution, see England

Goens, Rijcklof van, 236

Goff, Jacques Le, 1-2

Gomarists, 46, 48, 49, 53, 56, 60

Gomarus, Franciscus, 45-47, 291

Gosset, Claude, 262

Gouda, 192

Gregory XIII, Pope, 80

Grey de Wilton, Arthur Grey, 14th baron 155

Grol, 143

Groningen, 132

Grotius, Hugo, 47

Gubec, Matej, 108

Gueux, see Beggars

guild halls, 11, 165-181

guilds, 11, 16, 29, 82, 165-181

Guise, Henry I, duke of, 114, 120,

Guise, Louis II, cardinal of, 124

Gunpowder Plot, see Guy Fawkes Day

Güntzer, Augustin, 279

Guy Fawkes Day, 7, 65, 118

Guyon, Fery de, 197-201

Haarlem, 130, 188, 193-194

Habsburg, House of, 45, 52, 105, 130, 140, 143, $187,189,212,213,288,289,290,321$

hagiography, 118, 119, 279, 283

Hakluyt, Richard, 225

Halbwachs, Maurice, 203

Halde, Jean-Baptiste du, 231

Halle, 210

Hanover, house of, 71

Harari, Yuval, 17

Hardenberg, 54

Heidelberg catechism, 53

Heiligenstadt, 276

Hembyze, Jan van, 55

Henry III, king of France, 124

Henry IV, king of France, 112, 122-123, 263

Henry VIII, king of England, 161, 174, $176-177,305$

heralds, 6,170

Heraugière, Charles de, 134, 136, 139-140, 147

heretics, 29, 57, 104, 111, 115, 119, 190, 195-198, 199, 204 
heritage, $31,47,54,265,283,284,319$

heroism, 11, 20, 55, 120, 130, 140, 146, 150, 185-187, 191-193, 195, 200, 211, 217, 283

historical consciousness, 2-4, 21, 315, 317, $318,324,325,328,329$

historiography, $3,11,16,18,55,111-125,150$, $155,163,167,185,186,188,190,192,194$, $203,285,298,307,319$

Hoadly, Benjamin, 69-70, 73

Hobsbawm, Eric, 1-2, 329

Hohenlohe, Philips von, 135

Holland, province of, $6,47-52,54-55,60$, 132, 143, 190-191, 226, 288-289, 291, 293 court of, 49

states of, 47

synod of, 291

Holocaust, 12-13, 22, 206

Hoorn, 54, 194-195

Horne, Philip de Montmorency, count of, 58

Huguenots, 50, 111-125, 201-202, 212, 253-267

Hulst, 132

Hungary, 9, 93-100, 104, 109

Hutchinson, Lucy, 300-303, 307-308, 311

iconoclasm, 55, 195, 197, 218, 323

iconography, 14, 125, 161, 226, 233

identity

artisan, $165^{-181}$

exile, 20, 209, 285-287, 295

national, 96, 156-157, 163, 164

personal, 16, 18, 97, 103, 263, 301, 327

political, $72,74,75$

religious, $63,77-79,83-85,87,89,91$, $104,113,114,190,209,210,215^{-217}$, 263,284

imagined community, 224

Inchiquin, Murrough O'Brien, 1st earl of $15^{0}$

Indians see Americans, native

infanticide, 148, 169-170, 227

information revolution, 1

inheritance, 32, 72, 136, 298, 301-307, 309, 311, 312, 317

inquisitions, 14, 56, 204, 212

inscriptions, see artefacts

Ireland, 9, 11, 149-150, 152-157, 159-162, 164

Ireton, Henry, 149

Isabella of Bourbon, 322

Israel, 87,291

Istvánffy, Stephanus, 105, 108

ius theutonicum, 29
Jacobites, 66, 70-74

Jagiellon, House of, 31

Jakinet, Johannes, 183-185, 190, 199

James II, king of England, 63-64, 67-69, 71-73, 75

Jaquinet, Jean, see Jakinet, Johannes

Jesuits, 19, 38, 70, 223, 231, 236, 245, 248-250, 275,276

Jesus Christ, 108, 178

jetons, see artefacts

Jeune, Jean Robert Le, 263

Jews, 12, 28, 29, 33, 287

John Casimir II, king of Poland, 40

Johnson, Samuel, 68

Józefowicz, Jan Thomas, 41

Junius, Maria Anna, 269, 278-279

Kara Mustafa, grand vizier, 273

Kascach, Dionisious, 99

Kazimierz III, king of Poland, see Casimir III

Kiberd, Declan, 163

kinship, see family

Kircher, Athanasius, 19, 275-279

Kitzmann, Andreas, 207

Kleinschroth, Balthasar, 273-275, 279

Koppándi, Gregorius, 100-101

Kopytoff, Igor, 205

Koselleck, Reinhardt, 3-4, 316

Kromer, Martin, 35-36, 38, 42-43

Lalaing, Charles de, count of Hoogstraten 196

Lampsins, Jacoba, 291

landscape, 11, 22, 131, 136, 143, 147, 149, 152, $153,156,157,159,161,163,164,191,207,208$, 210, 214, 217, 221, 223, 224, 237, 243

Latin, 31, 36, 40-42, 120, 139, 193, 231, 298

Latour, Bruno, 249-250

Le Mans, 117

Le Puy, 118, 256-257

Lee, Jan Pieterszoon van der, 191-193, 200

Leendertsz, Meindert, 200

Leiden, 45, 57, 130, 144, 188, 191, 193

Lemberg, 7-8, 27-43

Leo $\mathrm{X}$, pope, 93,98

Leon, see Lev

Leopolis, see Lemberg

Leslie, Charles, 73

Lev/Leon I of Galicia (c.1228-c.1301), 31, 32, $35,36,38,42$

Levy, Daniel, 13, 206

leyenda negra, see Black Legend

liberty, see freedom 
Licensing Act, 66

Liège, 293

Lille, 195, 199

Limburg, 293

lineage, 6 , 16, 293, 300-313

linear history, 2, 155, 164, 304, 315, 318, 329

linear time, 23, 102, 304, 315, 316, 329

literacy, 1, 11, 16, 22, 297

lieux de mémoire, see memory, sites of

London, 11, 16, 64, 67-68, 71, 165, 167-169, 173-175, 178, 181, 216, 283-284, 305

St Mary Woolnoth, 173

Louis XIII, king of France, 111

Louis XIV, king of France, 111

Louvain, 183-184

Lublin, diet of, 31-32, 34-35

Luther, Martin, 104, 116, 219

Lutheranism, 77-91, 96, 104, 276

Lutsk, 39

Lviv, see Lemberg

Lvov, see Lemberg

Lyon, 118, 123, 262

Maastricht, 143

Mac Giolla Phádraig, Brian, 151

Maertensz, Clement, 54

Magdeburg, 29, 34, 88

Magdeburger Recht, 43

maidservants, 183, 184, 199, 260

Maimbourg, Louis, 111, 122

Malapert, Nicolas de, 290

Malines, 187

Mannheim, Karl, 214

maps, see cartography

Marchennes, 197-198

Margaret of Parma, governor of the

Netherlands, 198, 292

Marseille, 129

Martens

Carel, 291

family, 290-295

Hans, 290-292

Jacques, 291

martyrologies, 11, 113, 114, 115, 118, 119, 125, 151, 16o, 161, 211, 279

martyrdom, 11, 13, 18, 20, 77, 89, 96, 104, 108, $109,118,151,167,211,276,278$

Mary II, queen of England, Scotland and Ireland, 63, 68, 71-72

Mary, Virgin, 117, 161, 178, 190, 276

Mary Magdalene, 257

mass media, 1, 5, 6, 10, 12, 14, 147

massacres, 88, 105, 111, 114, 118-121, 157, 189, $256-260,263,266$ at Drogheda and Wexford, 149-150, 155, 157,160

St Bartholomew's Day, 88, 112, 119-121, $256-258,263$

material culture, 131-182, 204-205, 217-252, and see artefacts

Maurice, prince of Orange, 45, 47, 49-51, 53, $56,58,60,130,132,140,144,146,288$

McLuhan, Marshall, 227, 233, 248-249

medals, see artefacts

media, 1, 3, 5, 6, 10-14, 22, 65-66, 129-252

Medici, Catherine de, queen of France, 119

Médicis, Etienne, 256-257, 261

melancholy, 302, 309, 317-318

Melanchton, Philip, 54

memoirs, 16-17, 20, 115, 158, 197-199, 255,

259-261, 271, 279-280, 302-312

memory

art of, 3,223

collective, 13, 22, 151, 156, 167-168, 203-206, 214, 218, 292

communicative, $185^{-186}$

cosmopolitan, 13-14, 208-209

counter-, 9, 84, 89, 118, 15, 159, 250

crisis, $316-316,324,328$

cultural, 1, 12, 96-97, 186

episodic, $14-15$

family, 22, 215, 283-296, 297-314

ghettos, 285-286, 294

global, 1, 13, 14, 202-221, 222-248

glocal, 203-222

landscape, 131-164

local, 10, 128-148, 186, 199, 208, 298

multidirectional, 12

national, 4, 10, 23, 63-76, 111-125, 130, 139, 183-201, 207, 221, 224

sites of, 1-2, 11, 14, 175, 203, 2111, 222, 224

memoryscapes, 203-221

Mening, Stephanus, 102-103

Mesano, Oppiso de, cardinal, 36

Meteren, Emanuel van, 57

Meulen, Jan van der, 290

Meurs, Jacob van, 225, 227, 229, 231, 233, 235, 237, 239, 241, 243-244, 248

Meuse region, 293

Mézeray, François Eudes de, 120-121

Middle Ages, 6, 7, 11, 33, 39, 96, 99-101, 151, 165-181, 196, 225, 249, 325, 329

midwifery, 264-265

migration, 37, 203-207, 283-295

miracles, 196

mnemonic communities, 186

modernity, 1-23, 164, 315-329

Moelen, Frederik van der, 15 
Moelen, Pieter van der, 15

monasteries, 118, 161, 151, 321, 326

Monmouth, James Scott, 1st duke of, 67

monuments, see artefacts

Morgan, David, 218

Moses, 283, 291

Motte, John la, 283-284, 286, 291

Mountjoy, Charles Blount, 8th baron, 155, 161

Muelen, Andries van der (aka Andries van der Meulen), 289-290, 294

Muelen, Willem van der, 289

Müller, Georg, 78, 81-82, 84-90

murder, 8, 57, 93-94, 97, 103, 157, 160, 187, 266, 269, 273, see also massacres

myths, 98, 102, 149-163, 223, 298, 325

Nagerel, Jean, 115

Nantes, Edict of, 9, 112

nation, concept of, 17, 18, 19, 27, 35, 47, 111, 180, 185, 188, 190-191, 203, 211, 255, 269

national memory, see memory

nationalism, 1, 5-6, 21, 149, 154, 163, 200

neurosciences, 14

New Model Army, 149

New World, see Americas

news, 102, 103, 139, 144, 163, 188, 209-211, 26o, 274

Nicolaus of Bihar, 99

Nieuhof, Johan, 225-227, 229-231, 233, 235, $237,241,25^{\circ}$

Nijmegen, 132, 289

Nîmes, 118

Noah, 178

nobility, 6, 9, 25-42, 93-109, 136, 141, 187, 195, 219, 290-294

Noircarmes, Philip of St. Aldegonde, baron of, 195

Nora, Pierre, 1-2, 203, 324

Normans, 198, 292

nostalgia, 51, 69, 162, 288, 317, 318, 325, 327

Nottingham Castle, 302

novels, 200

novelty, 4, 53, 54, 171, 316-318, 321-324, 326, 328

nuns, 199, 262, 269, 273, 279

Nuys, 264

objects, see artefacts

oblivion, 9, 52, 79, 96, 109, 112, 116, 123-125, 186, 189-190, 254, 280, 289, 293, 295, 322, 327 acts of, 9,189

O'Brien, Murrough, see Inchiquin, earl of
Observant Franciscans, 104

old age, 54, 185, 189, 191, 194, 195, 298, 309

Oldenbarnevelt, Johan van, $47-51,56,5^{8}$, 132

Olick, Jeffrey, 2-4

oral traditions, 11, 150-154, 157, 159, 160, 183-186, 190, 193, 199, 200, 292, 298, 306, 307

Ormonde, James Butler, 1st duke of, $15^{\circ}$

Ottomans, 93, 98, 101, 226, 238, 269, 270, 273-275

Oudewater, 191-194

paintings, $5,117,118,124,144,147,178-180$, 200, 218, 224, 238, 250, 291 portraits, 6, 136, 139

Palma Cayet, Pierre, 122

Pamphlets, 12, 54-56, 65, 66, 69, 83-86, 90, $101-103,113,130,132,139,140,154,160,183$, 188, 212, 227, 233, 239, 241

Panhuys, family, 293-294

Paris, 18, 115, 120, 122-124, 259-260, 262, 264

Parker, George, 241, 243, 248

Parma, Alexander Farnese, duke of, see Farnese

Parma, Margaret of, see Margaret of Parma

Pater, Aletta, 291

patriotism, 48, 186, 187, 189, 193, 199, 269, 293

peace, $8,45,47-48,60,61,77-79,82,90,91$, 96, 111, 112, 120, 140, 189, 195, 289, 306 of Augsburg, 91 of Beaulieu, 112 of Bergerac, 112 of Cateau-Cambrésis, 197 of Westphalia, 144, 186

peasants, 9, 36, 37, 93-109, 195, 197, 264

peat, 10, 129-147, 191

Pecquencourt, 197-198

persecution, $58,77,88,187,211,266,283$, 284, 286, 287, 292, 293

Petty, William, 156-157

Philip, lord of St. Aldegonde, see Noircarmes

Philip II, king of Spain, 45, 56, 187

Philipps, Kendall, 208

philology, 7

Piedmont, 283

piety, see devotion

Pigafetta, Filippo, 262-263

Place, Pierre de la, 113

plague, 149, 188, 272-273

plays, see drama

plunder, 158, 187, 196, 269 
poetry, 6o, 74, 99, 132, 146, 151, 163, 200, 223, 327

Poitiers, 117

Poland, 7, 28, 31-37, 41-43

Polish-Lithuanian Union, 7

Pontius, Paulus, 141

Poole, Ross, 9

portraits, see paintings

postmodernism, 1, 2, 23

Post-Traumatic Stress Disorder (PTSD), 19

pre-mediation, 12

predestination, $8,45^{-48}, 53,54$

prints, see pamphlets and broadsheets

privileges, 27, 28, 32-35, 39, 41, 42, 57, 231, 320, 321

processions, 6 , 11, 112, 115, 117, 118, 123, 124, 141, 170, 171, 176, 177, 218, 257, 320

Próchnicki, Jan Andzrej, 37-38

profanation, see sacrilege

Promised Land, 158, 288, 291

propaganda, 9, 37, 45, 46, 48, 53, 54, 56, 6o, $64,65,74,140,143,189,212$

providence, 17, 21, 64, 67, 111, 113, 144, 161, $269,272,273,277-281,307,311$

public sphere, $3,96,104,190$

Puritanism, 283, 286, 293, 328

Ranke, Leopold von, 214

rape, 93, 101, 183, 184, 199, 256, 266

Rathaille, Aogán Ó, 151

rebellion, 9, 16, 41, 50-53, 67, 70, 73-74, 93-109, 149, 155, 187-193, 212, 288-289, 292, 305

redemption, 20, 108, 255

Reformed Church, see Calvinism

refugees, see exile

regicide, 69, 74

Regnier de La Planche, Louis, 113

relics, 133, 143, 147, 161, 218, 219, 318

remediation, 12

Remonstrants, see Arminianism

reputation, 20, 136, 165, 167, 169, 171, 181, 191

Reyes, Mitchell, 208

Ricci, Matteo, 223-224

Rijswijk, 49

ritual, 6, 11, 17, 22, 100, 108, 109, 117-119, 125,

$143,165,167,168,170,171,175,181,204$,

205,257

rocks, $11,153,161,164$

Romans (French town), 118

romanticism, 42, 162

Rome, 94, 95, 101, 181, 197, 275, 328

Rothberg, Michael, 12, 22

Rotterdam, 48, 54, 60
Rouck, Jan de, 16

Ruffi, Louis-Antoine de, 123

ruins, 11, 153, 161-163

rupture, $21,35,151,315,317,318,325-327$

Rus, 27-43

Sacheverell, Henry, 70, 72-74

sack, 115, 183, 187, 191, 192, 197

of Rome, 287

Sackville, 304

sacred space, 262, 325

sacrilege, 11, 94, 115, 116, 262, 266

Sainctes, Claude de, 115

Saint-Germain, 264

saints, 117, 118, 165, 167, 168, 174-176, 178, 322,326

St George, 108, 161, 165, 167-168, 174-176, 180

St Joseph, 178

St Martin, 257

St Patrick, 152

St Paul, 70, 168

salvation, 46, 85, 86, 94, 109, 185, 272, 282

Sarmatism, 36-37

Sattelzeit, 4

Saul, king, 87

Saxons, 308

Schelde, river, $5^{1}$

Scott, James, see Monmouth, duke of

secularization, 1, 53

Segesvár, 102

self, $3,18,74,255,266,271,278,280,300$ examination, 16, 277

sacrifice, 11, 193, 200

Senlis, 123

sentiments, see emotions

sermons, 6, 11, 64- 66, 69-71, 73, 83, 104, 117.

$151,154,171,173,175,188,283$

sexual violence, see rape

Sidney, Henry, 155

sieges, 41, 117, 123, 124, 130, 131, 135, 139-141, 143-147, 161, 183, 188, 191-194, 262-264, $271,273-275,290$

Sigismund I, king of Poland, 36

Sigismund II August, king of Poland, 30, 33,36

Sigismund III, king of Poland, 32, 35, 38

silence, see oblivion

silverware, see artefacts

sin, 18, 20, 46, 255, 261, 272

skippers, 130, 132, 133, 139

slavery, 12, 22

Sleidan, Johann, 113

Smyth, William, 156, $15^{8}$ 
Soeteboom, Hendrik Jacobszoon, 193-194, 199-200

soldiers, 11-12, 45, 51, 93, 95, 127, 130-136, 141, 146-147, 153, 156-161, 183, 187, 190, 192, 194, 196-200, 259-26o, 264, 269, 273, 275, $277-28,290$

Solikowski, Jan-Dymitr, 32

songs, 11, 74, 90. 132, 139, 147, 188, 198-198, 298

souls, 6o, 94, 172, 270, 272-273, 277, 279

Southern Netherlands, 186-187, 189, 195, 285-286, 288, 294, 318, 321

Spain, $12-13,45,48,5^{0-51}, 53,56,60,141$, $143,187,189,212$

king of, 12, 187

Spanish Fury, 290

Spinola, Ambrogio, 140-141, 143, 147

St James' Palace, 64

St John the Baptist, fraternity of, 168

Staiger, Clara, 273, 277, 279

stained glass, see artefacts

Stalker, John, 241, 243, 248

States General

Dutch Republic, 51-52, 132-133, 139-140, 14

France, 124

statues, see artefacts

steadfastness, 20, 84-85, 88, 211, 293

Steenvoorde, 195

Stow, John, 169

Straelen, Jan Baptist van der, 318-324, 326, 329

Stranger Church, 283, 285

Stuart, James, 71-72

Szapolyai, John, 105

Székely, Georgius, 99

Székely, Johannes, 102

Szerémi, Georgius, 108

Sznaider, Nathan, 13, 206

Tacitus, Publius Cornelius, 293

Tatars, $7,28,35,36,41,42$

Taurinus, Jacob, 54-57

Taurinus, Stephanus, 99

tears, $25^{8}, 276,278$

Temple, John, 160

Terdiman, Richard, 317, 320-321, 323, 325

The Hague, 6, 49, 51, 56, 60

Theodosia, Pontic Island of Caffa, 41

Thijs, Johan, 288-29o

Thirty Years War, 91, 96, 269-282

Thomas, Keith, 324

Thou, Jacques-Auguste de, 119-120, 122, 258-259
Tienen, 183

Tirlemont, see Tienen

tombs, 154, 169, 215, 309, 311, 320, 322

Tories, 21, 78, 79, 80

Torosowicz, Nigol, 38

Toulouse, 115-116, 118

Tournai, $195^{-198}$

Tours, 265

town hall, see city hall

Tradel, Georg, 78, 86-88

traditions, $2,4-5,8,11,16,21,32,36,42-43$,

$55,78-79,82-84,116-120,150-154$,

$162,170,178-179,181,186,190-193,199$,

235, 251, 292, 25, 298, 306, 312, 315-316,

$320-321,328$

Transylvania, 100, 102

trauma, 19-20, 96-97, 109-111, 151, 154, 162, $189,215,251,254-255,265,281,328$

Trier, 293

Trouillot, Michel-Rolphe, 155

Turin, 116

Turks see Ottomans

Twelve Years Truce, 45-61, 140

Twin Towers, 12

Ulm, 84, 87-88

Ulster, 157

Unification of Poland and Lithuania, Act of, 31-33

Union of Utrecht, 53

Utrecht, 6, 53-54, 291-293, 326

Uytenbogaert, Johannes, 51, 54

Valenciennes, 190, 195, 202

Varillas, Antoine, 120

Velázquez, Diego, 143

Verdun, 115, 117

Vienna, 99, 269, 273-275

siege of, 273

virgins, $97,151,184,189$

Visconti, Honoratio, 37

VOC, 243, 250

Voetius, Gisbert, 291-292

Voisin de La Popelinière, Henri Lancelot, 113

Volhynia, 39

Volodymyr, 39

Voltaire aka François-Marie Arouet, 124

Vynyard, William, 165, 174-180

Ware, 309

Warsaw, 35

Waterland, 193-195, 200

Weigel, Johann Christoph, 239

Werf, Pieter Adriaensz. van der, 193 
Wexford, 149-150, 157-158, 163

Whigs, $8,70-74$

WIC, 13,26

widows, 139, 261, 302

William I, prince of Orange, 8, 47, 50, 54-57, 187,212

Apology, 56-57

William III, prince of Orange, $63-72,150$

Wittenberg, 87-88, 219

Wladisław IV, king of Poland, 39

women, 15-16, 22, 101, 87, 189, 26o-261, 297-313

World War I, 2, 12103
World War II, 12

Würzburg, 104

Yates, Frances, 3

Yeats, William Butler, 163 youth, 15, 305

Ypres, 190, 283

Ysbrantsz, Jan, 54

Zaandam, 193, 200

Zamość, academy of, 38

Zemplén, 99

Zutphen, 132 